Universidad Nacional de La Plata

Facultad de Humanidades y Ciencias de la EduCaCión

SeCretaria de Posgrado

\title{
LIBROS Y ALPARGATAS
}

LAS TRAMAS DISCURSIVAS Y ORGANIZATIVAS DEL PROCESO DE PERONIZACIÓN DE ESTUDIANTES, DOCENTES E INTELECTUALES DE LA UNIVERSIDAD DE BUENOS AIRES

1966 - 1974

LIC. NICOLÁS DiP

TESIS PARA OPTAR POR EL GRADO DE DOCTOR EN HISTORIA

Directora Dra. María Cristina Tortti

LA Plata, 12 de diCiembre 2016 


\section{Agradecimientos}

Si bien cada una de las palabras que conforman esta investigación es responsabilidad exclusiva del autor, la tesis tiene de fondo un trabajo colectivo de largo aliento y un respaldo institucional sin los cuales hubiera sido imposible realizarla.

Mi mayor agradecimiento a Cristina Tortti, por su enorme compromiso y dedicación. En especial, su compañía y guía en todo este recorrido final. Por enseñarme a investigar y apoyarme desde mis primeros pasos como estudiante. Mi deuda intelectual con ella y mi reconocimiento por todo su esfuerzo.

También quisiera agradecer a mis compañeros del Equipo de Investigación "Las formas y los sentidos de la política y la militancia: la nueva izquierda argentina en los años sesenta y setenta", el cual dirige Cristina Tortti y está radicado en el Centro de Investigaciones Sociohistóricas (CISH) de la Facultad de Humanidades y Ciencias de la Educación de la UNLP. Con Mora González Canosa, Mauricio Chama, Alberto Bozza, Horacio Robles, Luciana Sotelo, Fernanda Volonté, Nayla Pis Diez, Anabela Ghilini y Santiago Stavale comparto desde hace años lecturas y discusiones enriquecedoras.

Otro reconocimiento importante es al Consejo Nacional de Investigaciones Científicas y Técnicas (CONICET) por haber financiado esta investigación a través de sus becas de posgrado. A la Facultad de Humanidades y Ciencias de la Educación y a la Facultad de Trabajo Social de la UNLP. En ambas casas de estudio llevo adelante mi formación y me desempeño como docente. Además, un agradecimiento particular a Fernando Barba y Marcelo Starcenbaum, el director y secretario del Doctorado en Historia, por el respaldo institucional.

También quisiera dedicarles un agradecimiento especial a quienes brindaron sus testimonios para esta tesis. En todos los casos me encontré con personas sumamente reflexivas y generosas, que estuvieron dispuestas a colaborar conmigo de todos los modos a su alcance. Sin duda, escuchar sus historias fue la experiencia más interesante que viví durante estos años de trabajo. Sin esas voces, esta investigación tampoco hubiera sido posible.

A Euge, mi vieja, mi viejo, mi hermano, mis hermanas, mis sobrinas, a Pato, a los Roberti, a los compañeros.

Nicolás Dip, 12 de diciembre 2016 
ÍNDICE

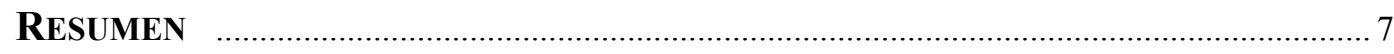

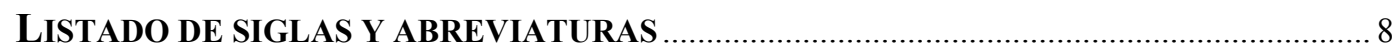

\section{PARTE INTRODUCTORIA}

\section{PRESENTACión De LA TESIS}

I - Acerca del área temática de interés ...........................................................................12

II - Estado de la cuestión .....................................................................................................17

III - Problema de investigación ...........................................................................................22

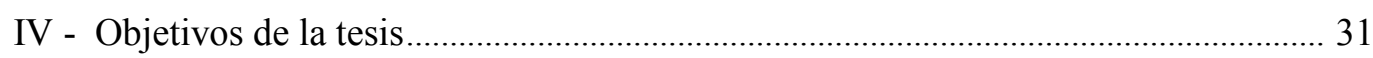

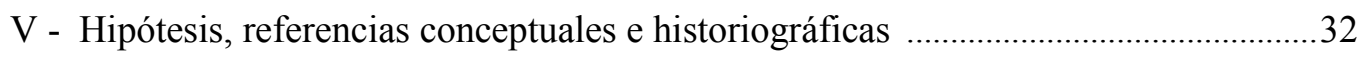

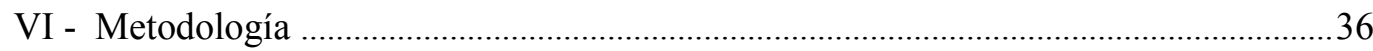

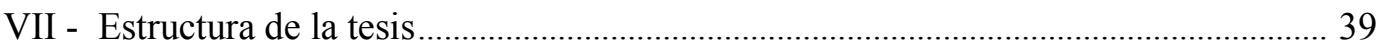

\section{PARTE I}

1966 - 1972

\section{Capítulo I}

LOS INICIOS DE LA PERONIZACIÓN

Del golpe de Onganía a la CGT de los Argentinos

1966 - 1970

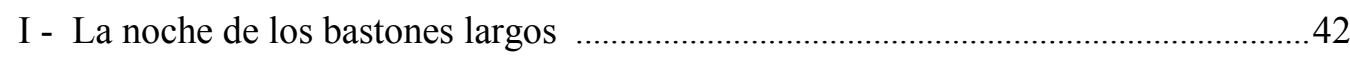

II - Nuevos estudiantes peronistas en la UBA …………................................................. 45

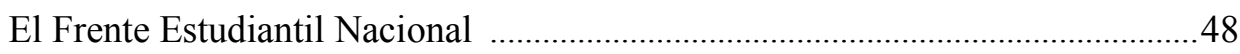

De la Unión Nacional de Estudiantes a la Corriente Estudiantil

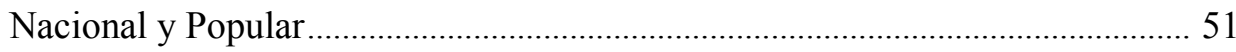

Las Juventudes Argentinas para la Emancipación Nacional ...................................54

III - Estudiantes peronistas de la CGT de los Argentinos ....................................................57

El fin de la CGT de los Argentinos y el sinfín 
de siglas del peronismo universitario .62

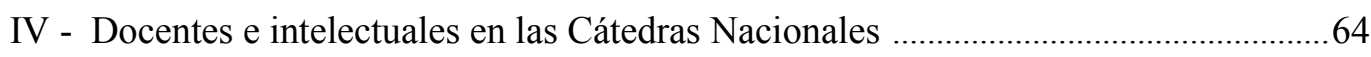

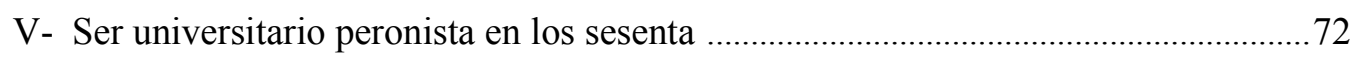

\section{Capítulo II}

\section{EN BUSCA DE UN RELATO PARA LA UNIVERSIDAD}

DE ANTROPOLOGÍA 3ER. MUNDO A LOS CUERPOS DE DELEGADOS

1968 - 1972

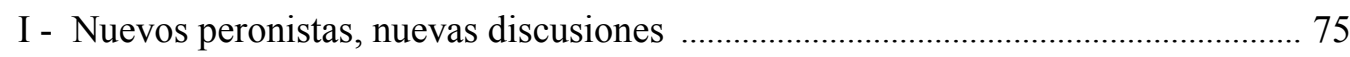

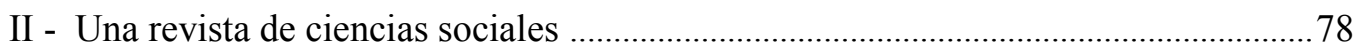

III - Primeros debates sobre la cuestión universitaria .........................................................81

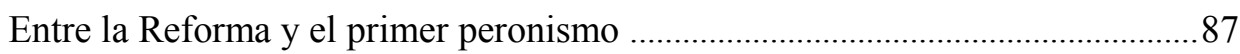

IV - El documento autocrítico y la primacía de la política ..............................................91

V - Los cuerpos de delegados y la muerte de la Reforma ................................................95

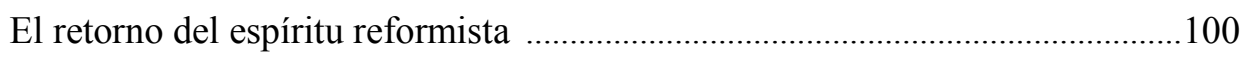

VI - Peronismo y universidad ........................................................................................... 103

\section{PARTE II}

$1972-1973$

\section{CApítulo III}

\section{LA PERONIZACIÓN EN LOS ALBORES DE LA PRIMAVERA CAMPORISTA}

De la PRoto-JUP a la ASUnCión de Puiggrós

$1972-1973$

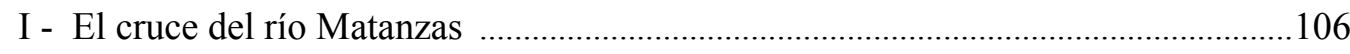

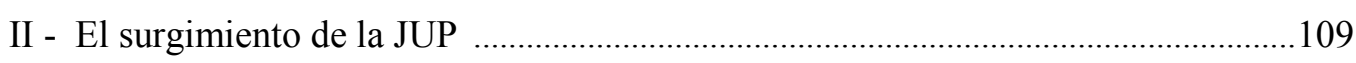

La unificación de las Juventudes Peronistas ………………………………….... 111

El sustrato militante previo: de la proto-JUP a la JUP ...................................... 114

III - Clivajes del peronismo universitario y panorama estudiantil porteño .................... 117

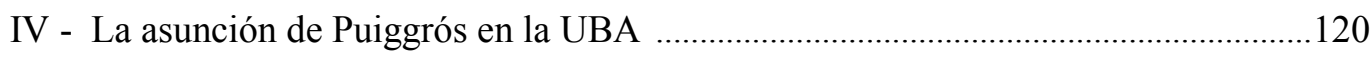

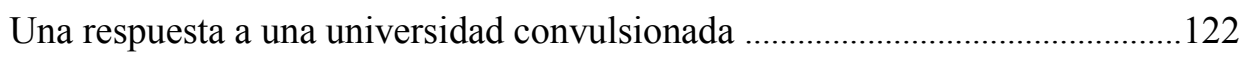

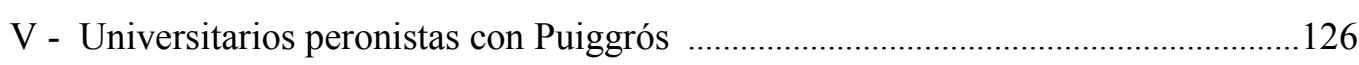

Los Equipos Político-Técnicos y la Agrupación Docente

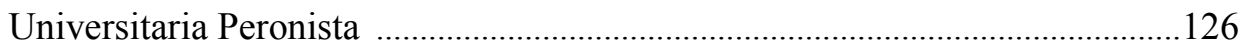


Agrupación de Abogados Peronistas ...................................................................130

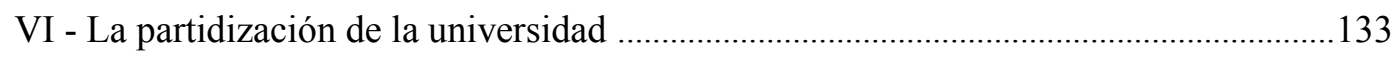

\section{CApítulo IV}

\section{UN PROYECTO PARA LA UNIVERSIDAD}

\section{DE LA REVISTA ENVIDO A LA JUP Y ADUP}

\section{$1972-1973$}

I - Dos entrevistas como punto de partida .136

II - Una revista peronista de política y ciencias sociales . .140

Del humanismo al peronismo .145

III - Un proyecto para la nueva universidad .150

Entre la Reforma y el primer peronismo .............................................................. 154

Un hervidero de discursos sobre la universidad ....................................................158

IV - Peronistas que piensan y gobiernan la universidad 162

\section{PARTE III}

1973 - 1974

\section{Capítulo V}

EL AUGE Y OCASO DE LA PERONIZACIÓN PORTEÑA

De Puiggrós a la Ley Taiana

1973 - 1974

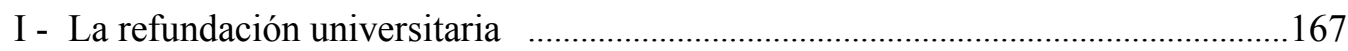

II - La gestión de Puiggrós y el respaldo del activismo universitario ...........................169

La interna peronista en la UNPBA ....................................................................... 174

III - Los centros de estudiantes y la refundación de la FUBA ……………………….....179

IV - La izquierda peronista ante la Ley Taiana ...............................................................186

V - De la disidencia a la Misión Ivanissevich ................................................................ 193

La nueva noche de los bastones largos .............................................................200

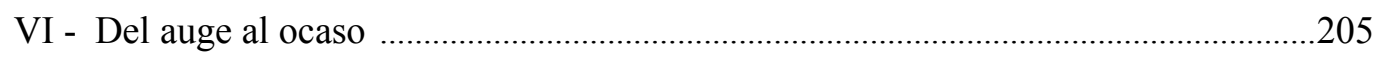




\section{CONCLUSIONES}

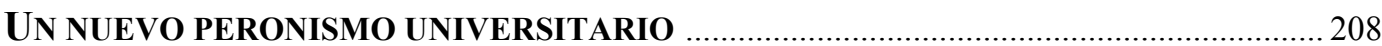



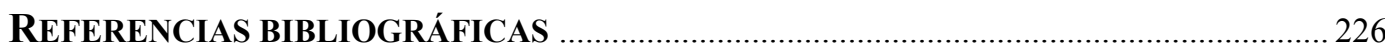

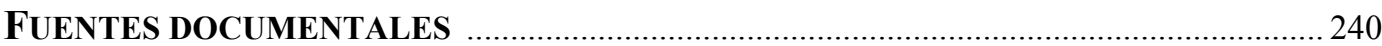

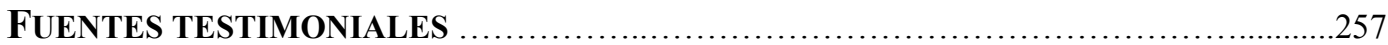




\section{LIBROS Y ALPARGATAS}

\section{LAS TRAMAS DISCURSIVAS Y ORGANIZATIVAS DEL PROCESO DE PERONIZACIÓN DE}

ESTUDIANTES, DOCENTES E INTELECTUALES DE LA UNIVERSIDAD DE BUENOS AIRES 1966 - 1974

\section{RESUMEN}

Desde los estudios sobre la nueva izquierda argentina, la presente tesis busca contribuir a un mayor conocimiento de la politización de las universidades en los años sesenta y setenta. En el marco de esta problemática, se propone estudiar el proceso de peronización de estudiantes, docentes e intelectuales de la Universidad de Buenos Aires (UBA), entre la intervención de las unidades académicas dispuesta por el régimen militar de Juan Carlos Onganía y la sanción de la ley universitaria 20.654 en la última presidencia de Juan Domingo Perón. Por esta razón, la investigación busca reconstruir el origen, la trayectoria y la perspectiva político-académica de las principales organizaciones que se identificaron con el peronismo y lo interpretaron como una alternativa revolucionaria legítima; las características más relevantes de los proyectos de universidad que impulsaron y las controversias que entablaron con otros sectores del campo político-cultural; así como la influencia que ejercieron sobre las políticas y debates universitarios más importantes del tercer gobierno peronista.

A partir de bibliografía especializada, fuentes documentales y testimoniales, esta investigación analiza las tramas organizativas y discursivas que fueron el sustento del proceso de peronización. Para abordar esas dos dimensiones, indaga el itinerario político-académico del Frente Estudiantil Nacional, la Unión Nacional de Estudiantes, las Juventudes Argentinas para la Emancipación Nacional, los Comandos Estudiantiles Peronistas, la Corriente Estudiantil Nacional y Popular y las Cátedras Nacionales. Asimismo, estudia los debates sobre la cuestión universitaria propuestos en las revistas Antropología 3er. Mundo y Envido. Finalmente, examina la influencia que tuvieron la Juventud Universitaria Peronista y la Agrupación Docente Universitaria Peronista en la gestión de Rodolfo Puiggrós como rector interventor de la UBA y en las controversias que antecedieron a la sanción de la ley universitaria de 1974.

Palabras Clave: nueva izquierda, peronismo, universidad, peronización 


\section{LISTADO DE SIGLAS Y ABREVIATURAS}

AAP - Agrupación de Abogados Peronistas ADUP - Agrupación Docente Universitaria Peronista AEP - Agrupación de Estudiantes Peronistas AGA - Asociación Gremial de Abogados ANDE - Agrupación Nacional de Estudiantes APEBA-17 - Agrupación Peronista de Base 17 de Octubre APR - Alianza Popular Revolucionaria APRA - Alianza Popular Revolucionaria Americana APUBA - Asociación del Personal Universitario de Buenos Aires ARAU - Agrupación Reformista Universitaria AREM - Agrupación Reformista de Estudiantes de Medicina ARFYL - Acción Reformista de Filosofía y Letras ARP - Acción Revolucionaria Peronista ASA - Asociación Sindical Argentina ATE - Asociación de Trabajadores del Estado AUL - Agrupación Universitaria Liberación AUN - Agrupaciones Universitarias Nacionales BAPDE - Bases Peronistas de Derecho CAEH - Centro Argentino de Economía Humana $\mathrm{CdeO}$ - Comando de Organización

CEA - Corriente Estudiantil Antiimperialista CENAP - Corriente Estudiantil Nacional y Popular CEP - Comandos Estudiantiles Peronistas CGE - Confederación General Económica CGT - Confederación General del Trabajo CGTA - Confederación General del Trabajo de los Argentinos CGU - Confederación General Universitaria CIAS - Centro de Investigaciones y Acción Social CLAEH - Centro Latinoamericano de Economía Humana $\mathrm{CN}$ - Cátedras Nacionales CNBA - Colegio Nacional Buenos Aires 
CNRR - Comité Nacional de Recuperación Revolucionaria del Partido Comunista de la Argentina

CNU - Concentración Nacional Universitaria

COFADE - Comisión de Familiares de Detenidos

CONDOR - Centros Organizados Nacionales de Orientación Revolucionaria

CRU - Comando Revolucionario Universitario

CT - Consejo Tecnológico

CTERA - Confederación de Trabajadores de la Educación

CTP - Comando Tecnológico Peronista

CUP - Coordinadora Universitaria Peronista

DC - Democracia Cristiana

EGP - Ejército Guerrillero del Pueblo

EPT - Equipos Político-Técnicos

FANDEP - Federación de Agrupaciones Nacionales de Estudiantes Peronistas

FAP - Fuerzas Armadas Peronistas

FAPES - Fundación Argentina para la Promoción del Desarrollo Económico y Social

FAR - Fuerzas Armadas Revolucionarias

FATDUBA - Federación de Trabajadores Docentes Universitarios de la Universidad de

Buenos Aires

FAU -Frente Antiimperialista Universitario

FAUDI - Frente de Agrupaciones Universitarias de Izquierda

FEN - Frente Estudiantil Nacional

FEN-OUP - Frente Estudiantil Nacional y Organización Universitaria Peronista

FFyL - Facultad de Filosofía y Letras

FJC - Federación Juvenil Comunista

FM - Franja Morada

FORJA - Fuerza de Orientación Radical de la Joven Argentina

FORPE - Fuerza para la Organización Revolucionaria Peronista

FRECILINA - Frente Cívico de Liberación Nacional

FUA - Federación Universitaria Argentina

FUBA - Federación Universitaria de Buenos Aires

FUL - Frente Universitario de Liberación

FULNBA - Federación Universitaria para la Liberación Nacional de Buenos Aires

FURN - Federación Universitaria de la Revolución Nacional 
GAN - Gran Acuerdo Nacional

GH - Guardia de Hierro

JAEN - Juventudes Argentinas para la Emancipación Nacional

JEC - Juventud Estudiantil Católica

JP - Juventud Peronista

JP Regionales - Juventud Peronista Regionales

JPRA - Juventud Peronista de la República Argentina

JRR - Juventud Radical Revolucionaria

JTP - Juventud Trabajadora Peronista

JUC - Juventud Universitaria Católica

JUP - Juventud Universitaria Peronista

LHBA - Liga Humanista de Buenos Aires

LIM - Lista de Izquierda Mayoritaria

MASLA - Movimiento Argentino de Solidaridad Latinoamericana

MBP - Movimiento de Bases Peronistas

MHR - Movimiento Humanista Renovador

MIP - Movimiento de Inquilinos Peronistas

MIR Praxis - Movimiento de Izquierda Revolucionaria Praxis

MIRA - Movimiento de Izquierda Revolucionaria Argentina

MLN - Movimiento de Liberación Nacional

MNJ - Movimiento Nacional Justicialista

MNR - Movimiento Nacional Reformista

MNRT - Movimiento Nacionalista Revolucionario Tacuara

MNT - Movimiento Nacionalista Tacuara

MOC - Movimiento Obrero Comunista

MOR - Movimiento de Orientación Reformista

MRP - Movimiento Revolucionario Peronista

MSTM - Movimiento de Sacerdotes para el Tercer Mundo

MUR - Movimiento Universitario Reformista

OAP - Organizaciones Armadas Peronistas

OUGT - Organización Única de Trasvasamiento Generacional

PB - Peronismo de Base

PC - Partido Comunista

PCR - Partido Comunista Revolucionario 
PJ - Partido Justicialista

PO - Palabra Obrera

PREJULI - Frente Justicialista de Liberación Nacional

PRIN - Partido Revolucionario de la Izquierda Nacional

PS - Partido Socialista

PSA - Partido Socialista Argentino

PSAV - Partido Socialista Argentino de Vanguardia

PSIN - Partido Socialista de la Izquierda Nacional

PSN - Partido Socialista Popular

PST - Partido Socialista de los Trabajadores

RR - Renovación Reformista

SITRAC - Sindicato de Trabajadores ConCord

SITRAM - Sindicato de Trabajadores MaterFer

SUD - Sindicato Universitario de Derecho

TAREA - Tendencia de Agrupaciones Revolucionarias Estudiantiles de Avanzada

TAU - Tendencia Antiimperialista Universitaria

TERS - Tendencia Estudiantil Revolucionaria Socialista

TUPAC - Tendencia Universitaria Popular Antiimperialista y Combativa

TUPAU - Tendencia Universitaria Popular de Arquitectura y Urbanismo

UBA - Universidad de Buenos Aires

UCA - Universidad Católica Argentina

UCR - Unión Cívica Radical

UCRP - Unión Cívica Radical del Pueblo

UEL - Unión de Estudiantes del Litoral

UES - Unión de Estudiantes Secundarios

UNE - Unión Nacional de Estudiantes

UNLP - Universidad Nacional de La Plata

UNPBA - Universidad Nacional y Popular de Buenos Aires

UOM - Unión Obrera Metalúrgica

UON - Universidad Obrera Nacional

UTN - Universidad Tecnológica Nacional

VC - Vanguardia Comunista 


\section{PresentaCión de la tesis}

\section{I - ACERCA DEL ÁREA TEMÁTICA DE INTERÉS}

En los últimos tiempos, el impulso de los estudios sobre la historia reciente argentina conformó un campo temático específico que es abordado desde distintas perspectivas disciplinares. Como señala la producción bibliográfica, el período que transcurre entre el derrocamiento del gobierno de Perón y el golpe cívico-militar de 1976 se caracterizó por la inestabilidad del sistema político, la ilegitimidad del poder del Estado y las recurrentes crisis económicas. La creciente conflictividad social de los años sesenta fue acompañada por un intenso proceso de modernización cultural, politización y radicalización que impulsó una serie de debates y rupturas en el interior de varios sectores políticos, sindicales, culturales, universitarios y religiosos. Las controversias estimularon una renovación de la cultura política argentina en un panorama internacional marcado por los conflictos de la Guerra Fría, la Revolución Cubana, la descolonización de África, la guerra de Vietnam, la Revolución Cultural China, las protestas antirracistas en los Estados Unidos y los brotes de rebeldía juvenil en Europa central.

El escenario político nacional sufrió fuertes transformaciones entre la proscripción del peronismo y la dictadura de Onganía (1955-1966). La continua intervención de las Fuerzas Armadas, la exclusión del movimiento peronista, la creciente conflictividad social y los fracasos de los gobiernos semi-democráticos de Arturo Frondizi y Humberto Illia conllevaron una gran inestabilidad política. Para Guillermo O’Donnell, esta situación manifestaba el "juego imposible" en el que estuvo encerrado un régimen político pretendidamente democrático, pero excluyente de las mayorías y prisionero de los "factores de poder", mientras que Marcelo Cavarozzi habla de un "sistema político dual” que condujo a la deslegitimación de las instituciones democráticas y a la erosión de la autoridad estatal ${ }^{1}$. En este contexto, empezó a gestarse una incipiente "cultura contestataria" caracterizada por prácticas y discursos que hablaban de liberación nacional, socialismo y revolución. Mónica

1 O’Donnell, G., El Estado Burocrático Autoritario, Bs. As., Ed. De Belgrano, 1982; Cavarozzi, M., Autoritarismo y Democracia, Bs. As., CEAL, 1983. 
Gordillo señala que dicho proceso habilitó un espacio de debate común entre sectores de distintas trayectorias ideológicas, provenientes del peronismo, la izquierda tradicional, el nacionalismo y el catolicismo. Las discusiones tenían como telón de fondo a la Revolución Cubana y a movimientos de liberación nacional de África y Asia ${ }^{2}$. Para Claudia Gilman, estas experiencias fortalecieron la convicción de que la historia cambiaba de escenario y tendría como protagonista principal al tercer mundo ${ }^{3}$.

El golpe de Estado de 1966 no consiguió desarticular el clima de oposición política y social que venía gestándose desde el derrocamiento de Perón. Las medidas autoritarias de Onganía no hicieron más que profundizar los conflictos de la política nacional ${ }^{4}$. Durante el régimen de la "Revolución Argentina" (1966-1973), se desató un cuestionamiento generalizado del orden social en las grandes revueltas y movilizaciones populares producidas a partir del Cordobazo. Las protestas provocaron una notable pérdida de legitimidad de las instituciones estatales y de las dirigencias de distintos ámbitos sociales, como los sindicatos, los partidos políticos y las universidades. Para Juan Carlos Portantiero, la situación evidenciaba una verdadera "crisis de hegemonía", mientras que O’Donnell y Cavarozzi hablan de una "crisis de dominación" que alcanzó la textura celular de la sociedad y evidenció la impugnación de todo tipo de autoridad ${ }^{5}$. Desde el punto de vista de Gordillo, el '69 abrió un "nuevo ciclo de protesta" caracterizado por el surgimiento de movimientos sociales de oposición a la dictadura que ensayaron nuevos repertorios de confrontación ${ }^{6}$.

Los trabajos de Cristina Tortti recurren al concepto de nueva izquierda para designar a ese heterogéneo conglomerado de fuerzas sociales y políticas que protagonizó un intenso proceso de protesta y agitación a fines de la década del sesenta ${ }^{7}$. Pese a provenir de diversas tradiciones políticas y culturales -el peronismo, la izquierda, el nacionalismo y el mundo

\footnotetext{
${ }^{2}$ Gordillo, M., "Protesta, rebelión, movilización: de la resistencia a la lucha armada, 1955-1973”, en James, D. (comp.), Violencia, proscripción y autoritarismo (1944-1976), Bs. As., Sudamericana, 2003.

${ }^{3}$ Gilman, C., Entre la pluma y el fusil, Siglo XXI, Bs. As., 2012.

${ }^{4}$ De Riz, L., La política en suspenso, 1966-1976, Bs. As., Paidós, 2000; Altamirano, C., Bajo el signo de las masas, Bs. As., Emecé Editores, 2007.

${ }^{5}$ Portantiero, J. C., "Economía y política en la crisis argentina", en Revista Mexicana de Sociología, No 12 , México, 1977; O’Donnell, G., Ob. cit., 1982; Cavarozzi, M., Ob. cit., 1983.

${ }^{6}$ Gordillo, M., Ob. cit., 2003.

${ }^{7}$ Existen estudios surgidos en el contexto de la "transición democrática" de los ochenta que reducen el fenómeno de la nueva izquierda al desarrollo de las organizaciones armadas. Claudia Hilb, Daniel Lutzky y María Matilde Ollier resaltan que las prácticas guerrilleras obstruyeron "desde afuera" el carácter espontáneo y democrático del movimiento de protesta popular surgido al calor del Cordobazo. Más tarde, Oscar Anzorena propone el concepto de nueva oposición para indagar las conexiones entre distintos actores de ese conglomerado de fuerzas, el cual involucraba un amplio espectro de experiencias sociales y políticas que no se reducían a las agrupaciones político-militares. Véase: Hilb, C., y Lutzky, D., La nueva izquierda argentina: 1960-1980, Bs. As., CEAL, 1984; Ollier, M., El fenómeno insurreccional y la cultura política (1969-1973), CEAL, 1986 y Orden, política y violencia, CEAL, Bs. As., 1989; Anzorena, O., Tiempo de violencia y utopía, Bs. As., Ediciones del Pensamiento Nacional, 1998.
} 
católico-, adquirió cierta "unidad de hecho" que le permitió desplegar acciones y discursos que combinaban demandas sectoriales, la impugnación a la dictadura y la reivindicación de programas socialistas y antiimperialistas ${ }^{8}$. Este movimiento fue radicalizando sus reclamos e incluyó distintas experiencias de oposición política, sindical y cultural, como la eclosión de corrientes insurreccionales, el fortalecimiento de direcciones combativas y clasistas en el movimiento obrero, la expansión de organizaciones armadas y la consolidación de tendencias cristianas ligadas a la teología de liberación ${ }^{9}$.

El proceso de protesta que articulaba demandas sociales y políticas también se manifestó en vanguardias artísticas y en prácticas profesionales vinculadas a la salud, la justicia y la educación. Estas experiencias enmarcaban sus reivindicaciones particulares dentro de proyectos de renovación cultural e institucional opuestos a las formas tradicionales de autoridad $^{10}$. Para Tortti y Adrián Celentano, las universidades fueron un ámbito privilegiado del proceso de politización y radicalización de las demandas sectoriales. El clima de agitación generó experiencias pedagógicas y políticas universitarias innovadoras e impulsó a una gran cantidad de estudiantes, docentes e intelectuales a vincularse con ámbitos ligados al peronismo revolucionario y a grupos de izquierda distanciados de la línea política tradicional del Partido Socialista (PS) y el Partido Comunista (PC) ${ }^{11}$.

Los diversos núcleos sociales, políticos y culturales de la nueva izquierda desarrollaron una multiplicidad de nexos entre sí. Esto propició un ambiente común para que se concibieran y fueran percibidos como parte del "pueblo" y la "revolución". Su presencia generó una sensación de amenaza en los sectores dominantes de la sociedad. A principios de los setenta, el régimen de Alejandro Lanusse (1971-1973) propuso el Gran Acuerdo Nacional

\footnotetext{
${ }^{8}$ Tortti, M. C., "Protesta social y nueva izquierda en la Argentina del Gran Acuerdo Nacional" y "Post Scriptum: la construcción de un campo temático", en Pucciarelli, A. (ed.), La primacía de la política. Lanusse, Perón y la Nueva izquierda en tiempos del GAN, Bs. As., Eudeba, 1999; Tortti, M. C., El viejo partido socialista y los orígenes de la nueva izquierda, Bs. As., Prometeo, 2009; Tortti, M. C., Che. Una revista de la nueva izquierda (1960-1961), Bs. As., CEDINCI, 2013.

${ }^{9}$ Existen diversos trabajos relacionados a estos temas. Entre otros, pueden consultarse: Balvé, B., El 69: huelga politica de masas. Rosariazo/ Cordobazo/ Rosariazo, Bs. As., Contrapunto, 1989; James, D., Resistencia e Integración. El peronismo y la clase trabajadora argentina 1946-1976, Bs. As., Sudamericana, 1999; Carnovale, V., Los Combatientes. Historia del PRT-ERP, Bs. As., Siglo XXI, 2011; Touris, C., "Sociabilidad e identidad político-religiosa de los grupos católicos tercermundistas en la Argentina (1966-1976), en Mallo, S. y Moreyra, B. (comps.), Miradas sobre la historia social en la Argentina a comienzos del siglo XXI, Córdoba, Centro de Estudios Históricos, 2008.

${ }^{10}$ Longoni, A. y Mestman, M., Del Di Tella a "Tucumán Arde”. Vanguardia artística y política en el '68 argentino, Bs. As., El cielo por asalto, 2000; Chama, M., "La expansión de los límites de lo posible. El itinerario de una experiencia innovadora en salud mental a fines de los '60”, en Pucciarelli, A., Ob. cit., 1999; Chama, M., "Movilización y politización: abogados de Buenos Aires entre 1968 y 1973”, en Pérotin-Dumon, A. (dir.), Historizar el pasado vivo en América Latina., Universidad Alberto Hurtado, 2007.

${ }^{11}$ Tortti, M. C. y Celentano, A., "Estudiantes, izquierda y peronismo en la Argentina", en Tortti, M. C. (dir.), La nueva izquierda argentina (1955-1976): socialismo, peronismo y revolución, Rosario, Prohistoria Ediciones, 2014.
} 
(GAN) con el objetivo de relegitimar el poder del Estado y detener la confluencia entre protesta social y política revolucionaria, mediante la convocatoria a elecciones y el retorno del peronismo al sistema político legal luego de más de una década y media de proscripción ${ }^{12}$. Por esta razón, Alfredo Pucciarelli señala que la nueva izquierda jugó un papel relevante en la definición de la correlación de fuerzas del escenario político. Este protagonismo se manifestó en la movilización social que impulsó la retirada de la dictadura y la reapertura electoral que culminó con la asunción de Héctor Cámpora como nuevo presidente el 25 de mayo de $1973^{13}$.

Durante las fuertes conflictividades de los sesenta y setenta, el movimiento peronista manifestó una creciente complejidad social y política. En esos años varios agrupamientos reinterpretaron las clásicas banderas antiimperialistas y de justicia social con los moldes ideológicos de la época ${ }^{14}$. Carlos Altamirano señala que la figura paradigmática de esta experiencia fue John William Cooke, quien empeñó el último tramo de su vida a identificar al peronismo con la Revolución Cubana ${ }^{15}$. En ocasiones, el mismo Perón acompañó este proceso al presentarse como partidario del socialismo nacional y un líder tercermundista. A su vez, una parte importante de la clase media antiperonista ensanchó las bases sociales y discursivas del movimiento al mixturar sus viejas tradiciones ideológicas con su nueva pertenencia política. La aparición de la CGT de los Argentinos, el Movimiento de Sacerdotes para el Tercer Mundo y la relevancia pública que adquirieron organizaciones político-militares como las Fuerzas Armadas Peronistas (FAP), Montoneros y las Fuerzas Armadas Revolucionarias (FAR) a principios de los setenta, evidenciaba la peronización de distintos actores de la sociedad argentina ${ }^{16}$.

Los sectores vinculados a la Tendencia Revolucionaria del peronismo y a Montoneros tuvieron un papel destacado en las protestas contra la dictadura militar, el retorno de Perón, la campaña del Frente Justicialista de Liberación Nacional (FREJULI) y la asunción

\footnotetext{
${ }^{12}$ Amaral, S. y Plotkin, M. (comps.), Perón: del exilio al poder, Bs. As., EDUNTREF, 2004; De Amézola, G., "El caso del realismo insuficiente. Lanusse, La Hora del Pueblo y el Gran Acuerdo Nacional", en Pucciarelli, A., Ob. cit., 1999.

${ }^{13}$ Pucciarelli, A. "Dilemas irresueltos en la historia reciente de la sociedad argentina", Revista Taller, № 5, Bs. As., 1997.

${ }_{14}$ Gil, R., La izquierda peronista (1955-1974), Bs. As., CEAL, 1989; Bozza, A., "La resignificación revolucionaria del peronismo y sus protagonistas durante la etapa de proscripción”, en Tortti, M. C., Ob. cit., 2014.

${ }^{15}$ Altamirano, C., Peronismo y cultura de izquierda, Bs. As., Siglo XXI, 2011.

${ }^{16}$ Dawyd, D., Sindicatos y política en la Argentina del Cordobazo. El peronismo entre la CGT de los Argentinos y la reorganización sindical (1968-1970), Bs. As., Pueblo Heredero, 2011; Pontotiero, G., Sacerdotes para el Tercer Mundo, Bs. As., CEAL, 1991; Martin, J. P., El Movimiento de Sacerdotes para el Tercer Mundo: un debate argentino, Bs. As., UNGS, 2010; Lanusse, L., Montoneros. El mito de sus 12 fundadores, Bs. As., Vergara, 2007; González Canosa, M., Las Fuerzas Armadas Revolucionarias: Orígenes y desarrollo de una particular conjunción entre marxismo, peronismo y lucha armada, Tesis Doctoral, FaHCE, UNLP, 2012.
} 
presidencial de Cámpora ${ }^{17}$. El creciente protagonismo les permitió construir espacios de influencia y poder en distintos niveles estatales, como en ministerios del gobierno nacional, el congreso y en varias administraciones provinciales, aunque sólo pudieron imponer claramente su hegemonía en el campo de la cultura y el ámbito universitario. Richard Gillespie plantea que la casa de estudio porteña fue una de las áreas más importantes que dirigió la izquierda peronista con el nombramiento de Rodolfo Puiggrós como nuevo rector interventor. $\mathrm{Su}$ gestión rebautizó a la institución como la "Universidad Nacional y Popular de Buenos Aires", contó con el respaldo de la Juventud Universitaria Peronista (JUP) e incluso de organizaciones estudiantiles del radicalismo y la izquierda, en un momento de gran visibilidad de actores radicalizados en la política nacional ${ }^{18}$.

Sin embargo, el escenario político-social sufrió fuertes cambios con la rápida renuncia de Cámpora y el enfrentamiento entre distintas facciones del movimiento peronista. La argentina experimentó uno de los períodos más controvertidos de su historia reciente entre 1973 y 1976. Trabajos como los de Liliana De Riz, Juan Carlos Torre y Maristella Svampa señalan la dramática superposición de la crisis del modelo populista con el desencuentro entre el líder retornado del exilio y los sectores que habían vinculado la oposición a la dictadura militar con la posibilidad de impulsar transformaciones más profundas. Las controversias desataron el trágico pasaje de una sociedad movilizada a una comunidad desarticulada y sumergida en una profunda crisis política y social ${ }^{19}$.

La presente tesis doctoral se enmarca en los estudios sobre la nueva izquierda y propone un enfoque socio-histórico que no circunscribe la politización y la radicalización al accionar de las organizaciones político-militares y al fenómeno de la violencia política. Como lo demuestra buena parte de la producción bibliográfica reciente, estos procesos comprendieron un arco más amplio de experiencias y distintos repertorios de acción. Las transformaciones del campo universitario de los sesenta y setenta manifestaban la complejidad de la cultura política de esos años. Los cruces entre política y universidad impulsaron a muchos estudiantes, docentes e intelectuales hacia nuevos posicionamientos frente a las controversias de la época. Los debates no se reducían a problemáticas políticas e

\footnotetext{
${ }^{17}$ Lenci, L., "Cámpora al Gobierno, Perón al Poder", en Pucciarelli, A., Ob. cit., 1999; Nievas, F., Las tomas durante el gobierno de Cámpora, Tesis de Maestría, FSOC, UBA, 1999.

${ }^{18}$ Gillespie, R., Soldados de Perón: historia crítica sobre los Montoneros, Bs. As., Sudamericana, 2008.

${ }^{19}$ De Riz, L., Retorno y derrumbe, Bs. As., Hyspamérica, 1986; Svampa, M., "El populismo imposible y sus actores, 1973-1976", en James, D., Ob. cit., 2003; Torre, J. C., "A partir del Cordobazo", en Ensayos sobre movimiento obrero y peronismo, Bs. As., Siglo XXI, 2012.
} 
ideológicas, como los diagnósticos sobre la lucha armada, el papel del peronismo y la izquierda. También involucraban discusiones sobre el movimiento estudiantil, los intelectuales y la universidad. En el contexto de esta problemática, el estudio del proceso de peronización porteña puede profundizar el análisis de distintas facetas de la politización de esos tiempos y contribuir a una mayor comprensión de experiencias que debatieron la cuestión universitaria en el marco de proyectos de transformación más amplios.

\section{II - ESTADO DE LA CUESTIÓN}

La peronización de universitarios es señalada con distinto grado de detenimiento en producciones académicas que indagan experiencias de la historia reciente de nuestro país desde distintas perspectivas disciplinares. Este corpus bibliográfico otorga un conjunto de elementos analíticos y empíricos que permiten estudiar la relación entre peronismo y universidad con mayor sistematicidad, profundidad y detenimiento. Dentro de este conjunto de trabajos, se destacan los que hacen hincapié en la historia de las universidades, el movimiento estudiantil y el campo intelectual. La mayoría de esas investigaciones concibe a los años sesenta y setenta como un entramado de articulaciones conflictivas entre la modernización cultural, los proyectos de renovación de las casas de estudio y la politizaciónradicalización de varios actores vinculados al sistema de educación superior. A su vez, proponen enfoques que relacionan el contexto político, el escenario cultural y el ámbito académico para examinar este tipo de procesos. A continuación, abordamos diversos núcleos problemáticos señalados por la bibliografía que no pueden prescindirse a la hora de analizar la peronización de estudiantes, docentes e intelectuales en la UBA. Tomamos como referencia tres etapas temporales con la finalidad de ordenar los principales aportes analíticos y empíricos a los propósitos y objetivos de esta investigación.

\section{$1955-1966$}

La identificación de sectores universitarios con el peronismo no puede entenderse sin los cambios que sufrió la sociedad argentina entre mediados de los cincuenta y principios de los sesenta. Conocidos estudios sobre la historia de las ideas y el campo intelectual analizan las transformaciones culturales producidas a partir del derrocamiento del gobierno peronista. A fines de la década del cincuenta, comenzó a ocupar un lugar relevante la problemática sobre el compromiso de los intelectuales. Oscar Terán indaga el fortalecimiento de las perspectivas que entendían que la política y la actividad intelectual debían marchar estrechamente unidas. Las reflexiones puramente teóricas estaban condenadas de antemano, frente a la necesidad de 
intervenir en los conflictos sociopolíticos de la época. En nuestro país, la politización del ambiente intelectual se vinculó con la "autoculpabilización" de una "franja crítica de pensadores de izquierda" que cuestionó su distanciamiento de las clases populares. Este sentimiento fue acompañado por una revalorización del peronismo y una crítica al papel que cumplieron el PS y el PC durante los gobiernos de Perón y en el golpe cívico-militar de $1955^{20}$.

Esta experiencia de autocrítica también es analizada por Altamirano. A su entender, entre 1955 y 1966 se entretejió en la izquierda argentina una literatura que hacía hincapié en la relación peronismo - pequeña burguesía. Los escritos otorgaban importancia a la visibilidad pública que había adquirido la clase media en tiempos de Perón. Los núcleos de diversas vertientes de izquierda distanciados del PS y el PC criticaron las posturas antiperonistas de ese sector. A partir de los ensayos de Juan José Hernández Arregui, Juan José Sebreli, Jorge Abelardo Ramos y Rodolfo Puiggrós, se conformó una "literatura socio-psicológica" sobre la pequeña burguesía que funcionó como un conjunto de textos de "mortificación" y "expiación". Estos sectores debían purgar las faltas que le indicaban esos relatos para hallar un camino de reconciliación con la "clase redentora": el proletariado peronista ${ }^{21}$.

Las investigaciones sobre el campo intelectual indagan la ruptura que una parte de la izquierda efectuó con la tradición liberal y la confluencia entre distintas corrientes políticoideológicas de los sesenta. La Revolución Cubana tuvo una importancia destacada en este proceso. Para Silvia Sigal, la gesta que encabezó Fidel Castro permitió un espacio de confluencia entre marxismo, nacionalismo y peronismo. Cuba le demostró a la izquierda que al socialismo lo podían hacer movimientos nacionales y con el correr del tiempo fortaleció en el peronismo un ala de tendencia radical $^{22}$. En este marco, distintos actores reinterpretaron las clásicas banderas antiimperialistas y de justicia social del movimiento peronista con los moldes ideológicos de la época ${ }^{23}$. Estas reconfiguraciones políticas e ideológicas impactaron en la "franja de intelectuales críticos" que cuestionaba el anti-peronismo de la izquierda tradicional. Por esta razón, muchos de ellos emprendieron experiencias de revisión que concluyeron en interpretaciones que acentuaban las potencialidades revolucionarias del

\footnotetext{
${ }^{20}$ Terán, O., Nuestros años sesenta, Bs. As., Puntosur, 1991.

${ }^{21}$ Altamirano, C., Ob. cit., 2011.

${ }^{22}$ Sigal, S., Intelectuales y poder en la década del sesenta, Bs. As., Puntosur, 1991.

${ }^{23}$ Los nuevos significados que adquirió el "hecho peronista" formaban parte de un proceso intelectual más amplio que Federico Neiburg denomina la "invención del peronismo". Para dicho autor, la interpretación de esta experiencia fue un tema central de los combates intelectuales y cualquier individuo interesado en hablar sobre la realidad social, política y cultural del país debió participar en debates sobre sus orígenes y su naturaleza. Según Altamirano, este proceso fue uno de los grandes ejes de variación de la relación entre el peronismo y la cultura de izquierda a lo largo de la segunda mitad del siglo XX. Neiburg, F., Los intelectuales y la invención del peronismo, Bs. As., Alianza, 1998; Altamirano, C., Ob. cit., 2011.
} 
movimiento liderado por Perón. Terán plantea que los nuevos posicionamientos permitieron la constitución de una nueva izquierda cultural que influyó en la radicalización de los años posteriores, donde muchas veces la noción de compromiso se trastocó en una participación política directa que subestimaba la tarea propiamente intelectual ${ }^{24}$.

La UBA no permaneció ajena a la politización del campo cultural e intelectual. Estudios sobre historia de las ideas, el movimiento estudiantil y la universidad analizan el protagonismo del estudiantado entre fines de los cincuenta y mediados de los sesenta. La mayoría otorga relevancia a la etapa del gobierno semi-democrático de Arturo Frondizi. El presidente del radicalismo intransigente contradijo muchas de sus propuestas electorales y dilapidó el respaldo de varios universitarios con la aprobación de la Ley Domingorena, las concesiones petroleras al capital extranjero y la aplicación del Plan CONINTES ${ }^{25}$. En este contexto, algunas organizaciones reformistas comenzaron a cuestionar la participación de la Federación Universitaria Argentina (FUA) y de la Federación Universitaria de Buenos Aires (FUBA) en la "Revolución Libertadora", como en la desperonización que siguió a la intervención universitaria de $1955^{26}$. También criticaron el proceso de modernización académica que impulsaban algunas facultades, como Ciencias Exactas y Filosofía y Letras ${ }^{27}$. Según Juan Sebastián Califa, este escenario demostraba que la casa de estudio porteña fue la institución que propugnó con mayor fuerza un programa modernizador que sintonizaba con el

\footnotetext{
${ }^{24}$ Terán, O., Ob. cit., 1991.

${ }^{25}$ Como Ley Domingorena se conoció a la normativa 14.557 sancionada en 1958, la cual permitió a la iniciativa privada crear universidades con capacidad para expedir títulos y/o diplomas académicos. En medio de las negociaciones parlamentarias, se desataron grandes manifestaciones que fueron conocidas con la consigna "enseñanza laica o libre". Los sectores reformistas defendían la tradición laica y pública del sistema de educación argentino, mientras los católicos eran partidarios de un régimen mixto y de que existiera la posibilidad de crear casas de estudio confesionales. La ley 14.557 reglamentó el artículo 28 de la normativa universitaria 6.403 decretada por el general Pedro Eugenio Aramburu el 23 de diciembre de 1955. Esto le costó a Frondizi la pérdida del respaldo de varios sectores del estudiantado reformista. Mignone, E., Política y universidad. El Estado Legislador, Bs. As., Lugar Editorial, 1998.

${ }^{26}$ Neiburg sostiene que en la desperonización de las facultades tuvo un papel relevante la FUBA ya que participó activamente en los concursos de todos los cargos docentes que se implementaron masivamente entre 1956 y 1957. Los mismos no contemplaban solamente los antecedentes académicos de los postulantes, sino la trayectoria y las posiciones políticas de los candidatos. La normativa universitaria 6.403 que sancionó Aramburu en 1955 establecía en su artículo 32 que no podían ser admitidos a los concursos "quienes hayan realizado actos positivos y ostensibles de solidaridad con la dictadura". Neiburg, F., Ob. cit., 1998.

${ }^{27}$ A principios de los sesenta, sectores del estudiantado reformista comenzaron a cuestionar bajo el rótulo de "cientificismo" a varias de las innovaciones académicas implementadas en la UBA luego del derrocamiento del peronismo, como la departamentalización de la estructura universitaria, la reforma de planes de estudios, la creación de nuevas carreras y organismos de investigación. A su entender, los enfoques "cientificistas" eran una deformación ideológica que representaba el quehacer científico como una tarea de expertos y especialistas, ocultando las fuerzas sociales y políticas que dirigían las investigaciones a determinados intereses. A su vez, cuestionaban los subsidios de organismos extranjeros por considerarlos parte de una política de colonización cultural. Posteriormente, estos temas serán sintetizados en Ciencia, política y cientificismo, un trabajo de Oscar Varsavsky de 1969 muy leído en ese entonces. Gil, G., Universidad y utopía. Ciencias sociales y militancia en la Argentina de los 60 y 70, Mar del Plata, EUDEM, 2010; Varsavsky, O., Ciencia, política y cientificismo, Bs. As., Capital Intelectual, 2010.
} 
proyecto del gobierno de Frondizi y su movimiento estudiantil uno de los primeros en asumir una política en marcado contraste con las autoridades docentes, cuando el desarrollismo empezó a tambalear ${ }^{28}$. Por su parte, Pablo Buchbinder señala que la radicalización del estudiantado expresa que los límites de la modernización académica se manifestaron mucho antes de la intervención decretada por Onganía en $1966^{29}$.

Los sectores cristianos del movimiento estudiantil también fueron protagonistas de los debates vividos en la UBA desde fines de los cincuenta. Las organizaciones humanistas obtuvieron mayor presencia política luego de las movilizaciones por la "enseñanza laica o libre”. En 1962, la Liga Humanista obtuvo la conducción del centro de estudiantes de la Facultad de Ciencias Económicas y dos personalidades de su tendencia política, Julio Olivera e Hilario Fernández Long, fueron los últimos rectores de la institución hasta el derrocamiento del gobierno de Arturo Illia. El proceso de renovación académica y de politización no fue ajeno a estas vertientes políticas. Para Beatriz Sarlo, el proyecto modernizador que inició el rectorado de José Luis Romero a mediados de los cincuenta fue continuado por las autoridades humanistas hasta la intervención de 1966. Por otra parte, los sectores radicalizados del estudiantado socialcristiano compartían muchas de las críticas que hacían los reformistas de izquierda a las políticas "cientificistas" 30 . La autora también plantea que no debe perderse de vista que entre 1956 y 1966 se debatió la función social de la universidad, la

\footnotetext{
${ }^{28}$ Califa, J. S., "El movimiento estudiantil en la UBA entre 1955 y 1976. Un estado de la cuestión y algunos elementos para su estudio", en Bonavena, P., Califa, J. S., Millán, M., (comps.), El movimiento estudiantil argentino: historias con presente, Bs. As., Ed. Cooperativas, 2007; Califa, J.S., Reforma y revolución: la radicalización politica del movimiento estudiantil de la UBA 1943-1966, Bs. As., Eudeba, 2014.

29 Buchbinder, P., Historia de las universidades argentinas, Bs. As., Sudamericana, 2010. Trabajos documentales y testimoniales muestran la autocrítica del movimiento estudiantil reformista y sus cuestionamientos a la modernización académica. En las entrevistas de Mario Toer se pueden consultar relatos de protagonistas de la época y en el libro de Carlos Ceballos, ex militante cordobés que ocupó cargos directivos de la FUA, manifiestos de las organizaciones estudiantiles. El trabajo de Catalina Rotunno y Eduardo Díaz Guijarro también reúne entrevistas y notas autobiográficas de docentes y militantes estudiantiles de la UBA, mientras que el de Bernardo Kleiner, un antiguo militante comunista de la Facultad de Medicina, otorga testimonios sustanciales al respecto. Véase: Toer, M., El movimiento estudiantil de Perón a Alfonsín, Bs. As., CEAL, 1988; Ceballos, C. Los estudiantes universitarios y la política 1955-1970, Bs. As., CEAL, 1985; Rotunno, C. y Díaz Guijarro, E. (comps.), La construcción de lo posible. La Universidad de Buenos Aires de 1955 a 1966, Bs. As., Libros del Zorzal, 2003; Kleiner, B., 20 años de Movimiento Estudiantil Reformista (1943-63), Bs. As., Platina, 1964.

${ }^{30}$ El proceso de renovación del mundo cristiano fue una experiencia amplia que no se redujo al ambiente universitario. A partir del Concilio Vaticano II (1962-1965), el Manifiesto de Obispos del Tercer Mundo (1967) y la Conferencia de Obispos Latinoamericanos de Medellín (1968), se desataron una serie de debates que socavaron progresivamente la influencia conservadora de la jerarquía eclesiástica. Los cambios fortalecieron un "espacio posconciliar" y una creciente vinculación de la cuestión religiosa con la cuestión social y política. Entrados los sesenta, la aparición de la revista Cristianismo y Revolución (1966-1971), dirigida por Juan García Elorrio, y la creación del Movimiento de Sacerdotes para el Tercer Mundo fueron hitos importantes de esta experiencia. Morello, G., "El Concilio Vaticano II y la radicalización de los católicos", en Lida, C., Crespo, H. y Yankelevich, P., Argentina 1976. Estudios en torno al golpe de estado, Bs. As., FCE, 2007; Lenci, L., "La radicalización de los católicos en Argentina. Peronismo, cristianismo y revolución (1966-1971)", en Sociohistórica, $\mathrm{N}^{\circ} 4,1998$.
} 
cual obtuvo diferentes respuestas sobre cómo convertirla en expresiones más adecuadas a las necesidades del país, la nación o el pueblo. Durante esa década, la mayor presencia de un movimiento estudiantil radicalizado irá consolidando la tendencia a pensar que "no hay reforma universitaria sin reforma social", aunque sólo más tarde el debate político capturó casi todos los espacios y la cuestión universitaria se convirtió llanamente en cuestión politica $^{31}$.

\section{$1966-1973$}

La bibliografía sobre la historia de las universidades, el movimiento estudiantil y el campo intelectual indaga los efectos del golpe de Estado de 1966 y señala que la peronización de estudiantes, docentes e intelectuales fue una experiencia de politización relevante que estuvo íntimamente vinculada a ese acontecimiento. Ana Barletta y Tortti plantean que la intervención de Onganía produjo importantes cambios en el escenario académico y no fue interpretada de la misma manera por los protagonistas de la época ${ }^{32}$. Muchos reformistas la consideraron un "parte aguas" porque eliminaba el modelo de gestión académica y científica basado en la autonomía, el gobierno tripartito y la libertad de cátedra; mientras que varios peronistas realizaron un diagnóstico positivo, ya que entendían que la represión terminaba acercando a los estudiantes y docentes a la clase trabajadora. Para este último sector, la nueva situación manifestaba las consecuencias de la exclusión política y que las universidades se habían comportado como "islas democráticas" frente a la proscripción que sufrían las clases populares. Por esta razón, si los reformistas utilizaron la coyuntura para convertir a la década anterior en los "años dorados", los peronistas la transformaron en la identidad de origen de una presencia político-partidaria en las casas de estudio ${ }^{33}$.

Los estudios de Augusto Pérez Lindo, Buchbinder y Daniel Toribio también consideran que la irrupción militar tuvo una importancia destacada en la reconfiguración del panorama político de las academias. Los acontecimientos de 1966 iniciaron un proceso donde

\footnotetext{
${ }^{31}$ Sarlo, B., La batalla de las ideas, Bs. As., Ariel, 2000.

${ }^{32}$ La intervención universitaria se llevó adelante el 29 de julio de 1966 mediante la sanción del decreto-ley 16.912. Las facultades de Medicina, Ingeniería, Arquitectura, Ciencias Exactas y Filosofía y Letras fueron tomadas por estudiantes y profesores que se oponían a la medida. Todas fueron desalojadas violentamente por fuerzas militares y policiales, dejando como saldo un número considerable de detenidos. Sergio Morero coordina un sucinto trabajo periodístico donde entrevista a protagonistas de "La noche de los bastones largos". Morero, S., La noche de los bastones largos, Bs. As., Ed. La Página, 1996.

${ }^{33}$ Barletta, A. M., y Tortti, M. C., "Desperonización y peronización en la universidad en los comienzos de la partidización de la vida universitaria", en Krotsch, P. (comp.), La universidad cautiva. Legados, marcas y horizontes, La Plata, Ed. al Margen, 2002. El trabajo de María Caldelari y Patricia Funes también indaga los significados que asignaron a la intervención de Onganía distintos actores universitarios de esos años. "La Universidad de Buenos Aires 1955-1966: lecturas de un recuerdo", en Cultura y política en los años 60, UBA, Oficina de Publicaciones del CBC, 1997.
} 
la hegemonía de las antiguas tradiciones reformistas terminaría siendo reemplazada por otra vinculada directamente a corrientes revolucionarias y al peronismo ${ }^{34}$. En sintonía, Ana Ramírez y Barletta argumentan que a los pocos años del golpe, un conjunto de estudiantes, docentes e intelectuales de trayectorias reformistas, católicas y socialcristianas reconstruyeron sus identidades previas cuando empezaron a reconsiderar el papel del movimiento peronista ${ }^{35}$; mientras Sarlo plantea que el decreto ley 16.912 y las medidas represivas no lograron detener la politización del estudiantado en el marco de procesos sociales más amplios. Esta situación permitió cambios imprevistos a fines de los sesenta. El movimiento estudiantil logró imponer "profesores progresistas o peronistas antiimperialistas", especialmente en las carreras humanísticas o en facultades como Arquitectura ${ }^{36}$. Por su parte, Califa señala que después del Cordobazo las agrupaciones estudiantiles humanistas e integralistas se fusionaron bajo el peronismo con muchos militantes reformistas, pero aclara que esta experiencia no puede entenderse sin dos procesos que se venían gestando desde fines de los cincuenta: el progresivo abandono de la Reforma de 1918 como faro de acción política de los estudiantes de izquierda y la radicalización de tendencias católicas y socialcristianas ${ }^{37}$.

Existe un conjunto de trabajos que abordan o hacen alusión a experiencias concretas del proceso de peronización de la casa de estudio porteña. Para Alejandra Reta, Aritz e Iciar Recalde, el estudiantado fue un actor relevante en la conformación de agrupamientos que reconocieron progresivamente al movimiento peronista como eje de su trabajo políticoacadémico. La Unión Nacional de Estudiantes (UNE) y el Frente Estudiantil Nacional (FEN) fueron las organizaciones más importantes hasta principios de los setenta. La primera se conformó con estudiantes integralistas y humanistas, mientras la segunda con sectores provenientes del reformismo de izquierda. Ambas canalizaron el "pasaje al peronismo" de muchos estudiantes y tuvieron una importancia destacada dentro del espacio de militancia peronista hasta la conformación de la JUP en $1973^{38}$. Frente a este tipo de lecturas, análisis recientes de Mariano Millán, Pablo Bonavena y Califa cuestionan la existencia de un proceso

\footnotetext{
${ }^{34}$ Pérez Lindo, A., Universidad, política y sociedad, Bs. As., Eudeba, 1985; Buchbinder, P., Ob. cit., 2010; Toribio, D., "La expansión de la Educación Superior en contextos de crisis sociales y políticas", en $L a$ universidad en la Argentina: miradas sobre su evolución y perspectivas, UNLA, 2010.

${ }^{35}$ Ramírez, A. J., "Radicalización y peronización de los estudiantes universitarios. El caso de la Universidad de La Plata", Cuadernos del CISH, No 5, 1999; Barletta, A. M., "Peronización de los universitarios (1966-1973)", en Pensamiento Universitario, No 9, UNQUI, 2001. Para Ramírez, existieron tres vías de ingreso del peronismo a la universidad: la vinculada al estudiantado, la relacionada al movimiento gremial de los trabajadores no docentes y la circunscripta al cuerpo de profesores, al campo de las ideas y a las discusiones intelectuales.

${ }^{36}$ Sarlo, B., Ob. cit., 2000.

${ }^{37}$ Califa, J. S., Ob. cit., 2007.

${ }^{38}$ Recalde, A. y Recalde, I., Universidad y liberación Nacional, Bs. As., Nuevos Tiempos, 2007; Reta, M. A., El proceso de peronización dentro del movimiento universitario en los años sesenta en la Argentina. El caso del Frente Estudiantil Nacional, Tesis de Maestría, FSOC, UBA, 2010.
} 
extendido de peronización en el movimiento estudiantil de esos años y sostienen que antes de 1973 el peronismo nunca llegó a convertirse en una fuerza de peso en la UBA, ni en otras casas de estudio ${ }^{39}$.

Por su parte, otras investigaciones señalan que en la identificación de estudiantes, docentes e intelectuales porteños con el peronismo jugaron un papel relevante las Cátedras Nacionales (CN) de la Facultad de Filosofía y Letras. Esta experiencia es abordada por trabajos que indagan la historia del campo intelectual y la evolución de la sociología argentina. Para Lucas Rubinich, expresaban la convergencia entre profesores cristianos que ocuparon espacios institucionales tras el golpe de Estado de 1966 y estudiantes radicalizados que interpretaban al peronismo como una alternativa política con orientaciones transformadoras. Como sus principales referentes provenían de diversas trayectorias ideológicas, combinaron categorías de tradiciones marxistas, cristianas y nacional-populares en la construcción de saberes y la discusión intelectual, aunque se desenvolvieron como un grupo cultural más que una corriente académica. Por esta razón, Rubinich compara su accionar con las vanguardias artísticas y remarca una dimensión "rupturista", en tanto subvirtieron las reglas establecidas en el mundo académico con su perfil asambleístico, la fuerte participación estudiantil y el rechazo a las formas tradicionales de evaluación. Además, considera que el nacionalismo cultural era la puerta de acceso a la política de muchos jóvenes de clase media de la época ${ }^{40}$. Por otra parte, Raúl Burgos entiende que las $\mathrm{CN}$ formaron parte de la peronización de pensadores de izquierda y del acercamiento crítico al marxismo de cuadros peronistas. De esta manera, eran la expresión intelectual y universitaria de un proceso que estaba ocurriendo en el peronismo desde 1966: la complejización de la radicalización

\footnotetext{
${ }^{39}$ Millán, M., Entre la universidad y la política. Los movimientos estudiantiles de Corrientes y Resistencia, Rosario, Córdoba y Tucumán durante la Rev. Argentina (1966-1973), Tesis de Doctorado, FSOC., UBA, 2013; Bonavena, P., 'Los estudiantes universitarios peronista. Del golpe de Onganía a los 'azos' del '69", en $V^{\circ}$ Jornadas de estudio y reflexión sobre el movimiento estudiantil argentino y latinoamericano, 2014; Califa, J. S., "El peronismo en la UBA durante la Rev. Argentina", en VIII Jornadas Jóvenes Investigadores, Instituto Gino Germani, 2015.

${ }^{40}$ Rubinich, L., "La modernización cultural y la irrupción de la sociología”, en James, D., Ob. cit., 2007. Diego Pereyra plantea una tesis similar: las $\mathrm{CN}$ fueron una experiencia que no tuvo contenidos científico-académicos, sino políticos y culturales. De esta manera, las caracteriza como parte de un momento histórico donde la práctica sociológica se subordina a la política y desaparece el campo autónomo del saber disciplinar. Para el autor, los años setenta son sinónimo de "deterioro" de la sociología universitaria. En cambio, Horacio González pone en cuestión la tesis de Rubinich, observa que si bien la caracterización de vanguardia cultural se justifica por el vínculo movilizador y político en la relación profesor-alumno, las $\mathrm{CN}$ no tenían un objetivo de carácter estético. Cabe destacar, que este último autor fue protagonista de dicha experiencia. Pereyra, D., "Cincuenta años de la Carrera de Sociología de la UBA. Algunas notas contra-celebratorias para repensar la historia de la Sociología en Argentina", en Revista Argentina de Sociología, Bs. As., CPS, V. 9, 2007; González, H., Historia crítica de la Sociología argentina. Los raros, los clásicos, los cientificos, los discrepantes, Bs. As., Ediciones Colihue, 2000.
} 
política con el ingreso de sectores originariamente vinculados a una tradición nacionalista asociada a la derecha argentina ${ }^{41}$.

Los estudios sobre la historia de las universidades tampoco pasan por alto la influencia de las $\mathrm{CN}$ en la politización y peronización de estudiantes, docentes e intelectuales. Para Buchbinder, contribuyeron a la transformación político-ideológica de los sesenta y a la conformación de una nueva cultura académica comprometida con el movimiento antidictatorial y el peronismo ${ }^{42}$. Por su parte, Claudio Suasnábar las considera como un puente ideológico entre la activación política estudiantil y el pensamiento nacional-popular. Además, resalta su esfuerzo por formular un proyecto universitario que, superando la mera crítica a la “isla democrática", legitimara la presencia del peronismo en las casas de estudio ${ }^{43}$. Desde una perspectiva más amplia, Gastón Gil argumenta que la conformación de las CN no puede desligarse de las organizaciones político-militares. Ambos actores formaron parte de un proceso de retroalimentación constante y progresivamente las $\mathrm{CN}$ fueron absorbidas por las discusiones y los objetivos de la militancia ${ }^{44}$.

La peronización de universitarios porteños también es vinculada con revistas políticoacadémicas como Antropología 3er. Mundo y Envido. Barletta y Laura Lenci señalan que estas publicaciones estaban atravesadas por varias redes de significación y sus colaboradores mantenían múltiples lazos con agrupamientos del campo político, cultural y académico ${ }^{45}$. Por su parte, Barletta y Tortti plantean que las dos publicaciones formaron parte del proceso de peronización y de la activación político-social más general que envolvió a las universidades

\footnotetext{
${ }^{41}$ Burgos, R., Los gramscianos argentinos, Bs. As., Siglo XXI, 2004.

${ }^{42}$ Buchbinder, P., Ob. cit., 2010.

${ }^{43}$ Suasnábar, C, Universidad e intelectuales. Educación y politica en la Argentina (1955-1976), Bs. As., Manantial, 2004.

${ }^{44}$ Gil, G., Ob. cit., 2010. Existen diagnósticos sobre las CN de intelectuales que pertenecieron a sus filas o discutieron con ellas. Para Eliseo Verón, carecieron de elementos conceptuales para validar una posición alternativa y no avanzaron más allá de la propuesta de disolver imaginariamente la ciencia en la política. Por esta razón, constituyeron una "etapa regresiva" en términos de desarrollo académico, ya que conformaron un "anticientificismo de derecha". Por su parte, González reivindica sus aportes por haber recuperado la lengua de "las tradiciones críticas más elevadas" del conocimiento social en un momento histórico lleno de "sombras, equívocos y violencia", aunque considera que allí radicó su "tragedia conceptual". Además, discute la idea de "anticientificismo de derecha" cuando señala que es un "clasificacionismo abstracto" que no comprende que la experiencia intentó articular una "memoria filosófica del conocimiento con las prácticas políticas". En sintonía, Alcira Argumedo afirma que las $\mathrm{CN}$ permitieron recuperar la potencialidad de los saberes populares latinoamericanos, cuya validez conceptual habría sido negada por la academia. Verón, E., Imperialismo, lucha de clases y conocimiento. 25 años de la carrera de sociología en la Argentina, Bs. As., Tiempo Contemporáneo, 1974; González, H., Ob. cit., 2000; Argumedo, A., Los silencios y las voces en América Latina: notas sobre el pensamiento nacional y popular, Bs. As., Colihue, 1993.

${ }^{45}$ Barletta, A. M., y Lenci, M. L., "Politización de las ciencias sociales en Argentina. El caso de la revista Antropología 3er. Mundo", en Sociohistórica, No 8, FaHCE, UNLP, 2001. En la actualidad, existen trabajos donde los propios directores de las revistas repasan la experiencia: Gutiérrez, G., "Antropología 3er Mundo. Cuatro década, algunas reflexiones sobre el contexto de origen", en Antropología 3er. Mundo, Bs. As., edición facsimilar de la Editorial de la Facultad de Filosofía y Letras, 2009; Armada, A., "Envido: por sus frutos los conoceréis", en El ojo mocho, $\mathrm{N}^{\circ} 16$, verano 2001-2002.
} 
de esos años. Su existencia suponía una definición de las ciencias sociales como políticas, incorporando la realidad nacional al análisis teórico y constituyendo una perspectiva identificada con el movimiento peronista ${ }^{46}$. A pesar de sus similitudes, Recalde establece contrastes en lo que refiere al debate sobre el papel de las universidades. A diferencia de Antropología 3er. Mundo, Envido fue un importante ámbito de discusión del proyecto de "universidad nacional y popular" que se intentó materializar en la casa de estudio porteña con la asunción de Cámpora el 25 de mayo de $1973^{47}$.

En la bibliografía no existen muchas referencias al tratamiento específico de la cuestión universitaria por parte de sectores peronistas. Algunos estudios sobre la politización de la comunidad académica plantean que la peronización no se redujo a la transformación de la identidad política de un conjunto de estudiantes, docentes e intelectuales que procedían de espacios antiperonistas o no peronistas. Para Ramírez y Barletta, la experiencia involucró una revalorización de la universidad que complejizaba los discursos que la reducían a una "isla democrática" o a un "reducto del régimen". En el contexto del GAN y del regreso del peronismo al poder, se plantearon nuevos proyectos de universidad con el argumento de combatir la penetración imperialista en el mundo de la cultura y contribuir al programa de "reconstrucción nacional" del futuro gobierno. A su entender, la perspectiva era innovadora porque proponía transformar las estructuras académicas en función de la dinámica política y al mismo tiempo consideraba a la universidad como un espacio donde se generarían aportes para materializar la conformación de una nueva sociedad ${ }^{48}$.

El análisis de la peronización de Ramírez y Barletta se diferencia del diagnóstico que realiza Sarlo. La ensayista sostiene que el escenario dictatorial, la radicalización política y la incorporación de capas medias al horizonte del peronismo revolucionario, generaron las condiciones para que varios actores del ámbito académico terminaran por disolver la cuestión universitaria en problemáticas de carácter estrictamente político. Por esta razón, antes de pensar un programa o una estrategia particular para las casas de estudio, muchos estudiantes, docentes, intelectuales y militantes sólo habrían hecho hincapié en que los verdaderos problemas del país se relacionaban con controversias que las superaban, como el atraso de las estructuras económico-sociales, la penetración imperialista, la proscripción del peronismo y la indecisión de los sectores medios en su alianza con los trabajadores. Esta concepción no se

\footnotetext{
${ }^{46}$ Barletta, A. M., y Tortti, M. C., Ob. cit., 2002.

${ }^{47}$ Recalde, A. y Recalde, I., Ob. cit., 2007; Recalde, A., Intelectuales, peronismo y universidad, Bs. As., Punto de Encuentro, 2016.

${ }^{48}$ Ramírez, A. J., Ob. cit., 1999; Barletta, A. M., "Una izquierda universitaria peronista. Entre la demanda académica y la demanda política (1968-1973)”, en Prismas, Nº 6, UNQUI, 2002.
} 
reducía a los sectores peronizados, sino que abarcaba al conjunto de la nueva izquierda ${ }^{49}$.

\section{3 - 1974}

La peronización también es señalada cuando la bibliografía sobre la historia del campo intelectual, las universidades y el movimiento estudiantil aborda la tercera etapa de gobierno peronista, por lo general haciendo hincapié en cuatro puntos: 1)- la amplia politización desatada con la asunción de Cámpora; 2)- el nombramiento de Puiggrós como rector en la UBA; 3)- la sanción de la Ley Taiana; y 4)- la designación de Alberto Ottalagano como nuevo interventor de la casa de estudio porteña en el gobierno de Isabel Perón.

En relación al primer y segundo punto, las investigaciones muestran la gran movilización social vivida en la efímera presidencia del delegado de Perón y que la identificación de universitarios con el peronismo culminó en la designación de Puiggrós el 29 de mayo de 1973, dando comienzo a la "Universidad Nacional y Popular de Buenos Aires". Para Califa, esta etapa estuvo marcada por la masificación de la militancia, la mayor injerencia de los partidos de izquierda y la preponderancia del peronismo. En este contexto, muchos intelectuales, docentes y estudiantes manifestaron una clara adhesión a la Tendencia Revolucionario y a Montoneros ${ }^{50}$. Bajo la influencia de este espacio, se conformaron la JUP y la Agrupación Docente Universitaria Peronista (ADUP) en 1973. Barletta, por su parte, sostiene que este período demostraba que la peronización era el hecho preponderante de una universidad masificada que había potenciado sus aristas críticas al calor de la dinámica política $^{51}$. Sigal plantea que terminó de afianzarse la partidización de la comunidad universitaria que venía gestándose desde Onganía, cuando los grupos estudiantiles y docentes dejaron de definirse a partir de la pertenencia a la universidad, la adhesión a la Reforma o a través una identidad que remitía a principios generales como el humanismo, para hacerlo en función de su vínculo con una determinada organización política ${ }^{52}$. Buchbinder señala que la JUP tuvo una influencia decisiva en la conducción de la universidad y la mayor parte de los interventores eran afines a la Tendencia y a Montoneros; mientras Sarlo aclara que actores que participaron en la refundación universitaria habían sido protagonistas de la politización de años anteriores, como lo demuestra la designación de O'Farrell -docente de las CN- en el cargo de decano de Filosofía y Letras $^{53}$.

\footnotetext{
${ }^{49}$ Sarlo, B., Ob. cit., 2000.

${ }^{50}$ Califa, J. S., Ob. cit., 2007, p. 81; Barleta, A. M., Ob. cit., 2002.

${ }^{51}$ Barletta, A. M., Ob. cit., 2001.

${ }^{52}$ Sigal, S., Ob. cit., 1991.

${ }^{53}$ Buchbinder, P., Ob. cit., 2010; Sarlo, B., Ob. cit., 2000.
} 
La bibliografía hace una caracterización de los principales lineamientos de la gestión de Puiggrós en la UBA. Trabajos como los de Omar Acha, Toribio y Sergio Friedemann plantean que su rectorado visualizó a las facultades como baluartes del cambio revolucionario e intentó llevar a adelante una transformación de sus estructuras administrativas, pedagógicas y curriculares. La nueva gestión impugnó las formas tradicionales de evaluación, la modalidad de clases teórico-prácticas, instauró exámenes grupales y reformó los planes de estudio. Un pilar de su política fue la abolición de las jerarquías del cuerpo docente y la expulsión de profesores que trabajaban en multinacionales o eran afines a la dictadura. También suprimió los exámenes de ingreso y creó nuevos organismos, como departamentos de planificación, institutos de investigación del tercer mundo y materias sobre la realidad $\operatorname{argentina}^{54}$. Por otra parte, existen estudios preliminares que analizan cómo se aplicaron esas medidas en facultades o unidades académicas particulares, como en Derecho, Filosofía y Letras, el Instituto del Tercer Mundo y el Instituto de Medicina del Trabajo ${ }^{55}$.

En el tercer punto, los trabajos destacan la importancia de la sanción de la Ley Taiana en marzo de 1974 y las controversias que giraron a su alrededor. Pérez Lindo señala que el período estuvo marcado por una politización que tendió a confundir las problemáticas universitarias con las luchas por la hegemonía del Estado, emprendidas por las distintas facciones del movimiento peronista. Sin embargo, argumenta que en medio de los conflictos surgieron numerosos proyectos de universidad y un conjunto de iniciativas innovadoras, donde la izquierda peronista convergía con vertientes reformistas vinculadas al marxismo y al radicalismo. A su entender, la ley universitaria 20.654 fue la primera normativa discutida democráticamente por la comunidad académica. Trataba de conciliar la autonomía, la planificación nacional, la democratización del gobierno universitario y el desarrollo de la enseñanza superior ${ }^{56}$. En esta línea, Mignone afirma que la ley expresaba el espíritu de los setenta e involucraba una síntesis de los principios universitarios del peronismo y el

\footnotetext{
${ }^{54}$ Acha, O., La Nación Futura. Rodolfo Puiggrós en las encrucijadas argentina del siglo XX, Bs. As., Eudeba, 2006; Toribio, D., Ob. cit., 2010; Friedemann, S., La Universidad Nacional y Popular de Buenos Aires (19731974). Una reforma universitaria inconclusa, FSOC, UBA, Tesis de Doctorado, 2015.

${ }^{55}$ Chama, M. y González Canosa, M., "Universidad, política y movimiento estudiantil: la Intervención de Kestelboim y el rol de la Juventud Universitaria Peronista en la Facultad de Derecho de la UBA", en Conflicto Social, No 5, 2011; Perel, P.; Raíces, E. y Perel, M., Universidad y dictadura. Derecho, entre la Liberación y el Orden, Bs. As., Ediciones del CCC, 2007; Moscona, G., Peronismo e intelectuales: la experiencia de las Cátedras Nacionales en la UBA en el periodo 1967-1974, Tesis de Maestría, FSOC, UBA, 2010; Daleo, G., Casareto, S., Cabrera, M., y Pico, A. (comps.), Filo (en) rompecabezas. Búsqueda colectiva de la memoria histórica institucional (1966-1983), Bs. As., Editorial de la FFyL, UBA, 2014; Chinchilla, J., "El Instituto del Tercer Mundo de la Universidad de Buenos Aires (1973-1974)", en Íconos, No 51, 2015; Martin, A, y Spinelli, H., "Para que el hombre vuelva a cantar mientras trabaja. El Instituto de Medicina del Trabajo (IMT) y la salud de los trabajadores", en Salud Colectiva, № 7, 2011.

${ }^{56}$ Pérez Lindo, Ob. cit., 1985.
} 
radicalismo. Respetaba las posiciones reformistas, pero adaptadas al panorama político del momento. Por esta razón, manifestaba que las universidades eran comunidades de trabajo y enunciaba los paradigmas de liberación nacional y justicia social ${ }^{57}$. Marina Moguillansky contrapone los postulados del peronismo con los del radicalismo, tanto en los cuarenta como en los setenta, aunque tiene en cuenta el acuerdo de ambos espacios en la aprobación legislativa ${ }^{58}$. Desde una perspectiva más atenta a la correlación de fuerzas, Buchbinder señala que los debates en torno a la sanción de la ley reflejaron el avance de la derecha peronista sobre los espacios de poder de la Tendencia; desplazamiento que venía fomentando Perón al asumir su tercer mandato. La nueva normativa contenía dos artículos polémicos que prohibían el proselitismo político partidario y las ideas contrarias al sistema democrático, además de permitir la intervención de las unidades académicas por decreto ${ }^{59}$.

En el cuarto y último eje, algunas investigaciones siguen una línea similar a Buchbinder cuando afirman que la renuncia de Puiggrós es un antecedente para entender el avance de la derecha peronista y la posterior designación de Ottalagano como nuevo interventor de la UBA en septiembre de 1974. Bonavena plantea que la temprana salida de Puiggrós del rectorado en octubre del año anterior desató un conflicto entre Perón, la JUP y los grupos estudiantiles que lo respaldaron, como Franja Morada (FM), el Movimiento de Orientación Reformista (MOR) y el Frente de Agrupaciones Universitarias de Izquierda $(\text { FAUDI })^{60}$. Pese a la resistencia, fue separado de su cargo y se iniciaron una serie de reemplazos. Alberto Banfi, Ernesto Villanueva, Vicente Solano Lima y Raúl Laguzzi ocuparon interinamente el rectorado hasta que Taiana fue sustituido como ministro de educación por Oscar Ivanissevich en agosto de 1974. De esta manera, la experiencia de la “Universidad Nacional y Popular de Buenos Aires" llegó a su fin con la política autoritaria de Isabel Perón ${ }^{61}$. En un reciente trabajo que repasa el sistema universitario en el último gobierno peronista, Laura Rodríguez muestra las discontinuidades entre las gestiones de

\footnotetext{
${ }^{57}$ Mignone, E., Ob. cit., 1998.

${ }^{58}$ Moguillansky, M., "Tradiciones políticas y modernización en las reformas peronistas de la Universidad", en Naishtat, F y Aronson, P. (comps.), Genealogías de la universidad contemporánea: sobre la ilustración o pequeñas historias de grandes relatos, Bs. As., Biblos, 2008.

${ }_{59}$ Buchbinder, P., "La universidad y el tercer peronismo: notas sobre el debate parlamentario en torno a la Ley Taiana”, en Millán, M. (comp.), Universidad, politica y movimiento estudiantil en Argentina, Bs. As., Final Abierto, 2014.

${ }^{60}$ El MOR era el brazo universitario del PC, el FAUDI del Partido Comunista Revolucionario y FM de la Juventud Radical. Los trabajos de Oscar Muiño contienen un conjunto de entrevistas a militantes y dirigentes del radicalismo, especialmente de FM. Muiño, O., La otra juventud. De la insignificancia al poder, Bs. As., Corregidor, 2011a. y Los días de la Coordinadora, Bs. As., Corregidor, $2011 \mathrm{~b}$.

${ }^{61}$ Bonavena, P., "El rector que no fue. La lucha de los estudiantes de la UBA contra la designación del odontólogo Alberto Banfi en octubre de 1973”, en Bonavena, P., Califa, J. y Millán, M., (comps.), El movimiento estudiantil argentino, Bs. As., Ed. Cooperativas, 2007.
} 
Taiana e Ivanissevich, mientras que Inés Izaguirre aporta datos sobre la intervención de Ottalagano, un representante de la extrema derecha peronista. Con su asunción se profundizaron los atentados de la Triple A y de otras organizaciones parapoliciales, lo cual culminó en un nuevo vaciamiento de la universidad y en una represión generalizada que se intensificó con el golpe de Estado de $1976^{62}$.

\section{III - Problema de inVestigación}

La bibliografía especializada otorga una serie de elementos analíticos y empíricos que permiten vislumbrar distintas facetas de la peronización de estudiantes, docentes e intelectuales de la UBA en los años sesenta y setenta. Sin embargo, todavía no existen investigaciones que examinen sistemáticamente ese proceso de politización. Especialmente, en lo que concierne a dos dimensiones: el plano organizativo y los discursos sobre la cuestión universitaria.

En relación a la primera, la mayoría de los trabajos disponibles hacen foco en algunas experiencias particulares como las $\mathrm{CN}$ y el FEN o adhieren a hipótesis generales que suponen a la peronización como una politización y partidización de la vida universitaria in crescendo desde 1966 hasta 1974. Atendiendo a que ese marco resulta insuficiente, esta tesis se propone analizar, desde una perspectiva procesual, la extensión y las características específicas de dicha experiencia, teniendo en consideración los diversos escenarios político-académicos del período estudiado y las articulaciones entabladas por una multiplicidad de actores, que incluyen desde organizaciones estudiantiles y agrupaciones docentes, profesionales e intelectuales hasta revistas y publicaciones a ellos asociados.

Estas consideraciones arrojan una serie de interrogantes que guían la investigación y buscan aportar nuevos conocimientos sobre el proceso socio-histórico abordado. El primer conjunto está referido a sus aspectos más generales y abarcativos: ¿Qué magnitud tuvo el "pasaje al peronismo" en la etapa que siguió a la llegada de Onganía? ¿Se trató de un proceso ampliamente difundido o estuvo acotado a ciertos espacios particulares? ¿Comenzó a partir de 1966 como señala la mayor parte de la bibliografía o pueden rastrearse antecedentes importantes en años anteriores? ¿Cuáles fueron los principales sectores estudiantiles, docentes e intelectuales que canalizaron esa experiencia? ¿Desde qué perspectivas teórico-políticas interpretaban al peronismo los universitarios que redefinían sus identidades desde itinerarios no peronistas o antiperonistas? ¿Con qué actores concretos del movimiento peronista tenían

\footnotetext{
${ }^{62}$ Rodríguez, L. G., Universidad, Peronismo y Dictadura 1973-1983, C.A.B.A, Prometeo, 2015; Izaguirre, I., "La Universidad y el Estado terrorista. La Misión Ivanissevich", en Conflicto Social, No 5, 2011.
} 
relaciones y cuáles eran las fuerzas político-universitarias con las que discutían? Un segundo conjunto de interrogantes se concentra en el período abierto en 1973, descripto por buena parte de la bibliografía como el momento de "culminación" de la peronización con el surgimiento de la JUP y ADUP, en el marco de la asunción de Cámpora y la designación de Puiggrós como rector interventor de la UBA ¿Cuáles fueron los procesos que permitieron la constitución de ambas agrupaciones? ¿Su surgimiento fue producto de experiencias asociativas previas o, por el contrario, fue casi exclusivamente expresión de la coyuntura abierta con el retorno del peronismo al gobierno tras 18 años de proscripción? ¿Cómo era la ubicación de estas agrupaciones dentro del movimiento peronista y su relación con las organizaciones del peronismo revolucionario?

En relación a la segunda dimensión puede encontrarse en los trabajos relevados dos posturas distintas en torno a la peronización y la cuestión universitaria, entendida esta última como el conjunto de discursos que pusieron en debate el perfil de las casas de estudio y su conexión con la sociedad, el movimiento estudiantil y los intelectuales ${ }^{63}$. Una plantea que el surgimiento de la nueva izquierda y la incorporación de capas medias al peronismo generaron las condiciones para que se disolvieran las controversias universitarias en problemáticas políticas más amplias. La otra, si bien señala que la peronización fue acompañada por el surgimiento de nuevos debates y proyectos de universidad, no avanza más allá de ciertas consideraciones de carácter general.

Este contrapunto muestra la existencia de un nudo problemático que aún no ha sido suficientemente explorado y, en consecuencia, evidencia la necesidad de abrir una nueva serie de indagaciones: ¿Cuáles fueron las razones por las cuales ciertos grupos decidieron adherir al peronismo rompiendo así con el tradicional antiperonismo de los universitarios? ¿Reivindicaban la política universitaria de los primeros gobiernos de Perón? ¿Cómo eran sus posturas respecto de la Reforma Universitaria de 1918? ¿La daban por muerta o superada como surgieren algunos estudios cuando indagan los años sesenta y setenta? ¿Cuáles eran los temas y las disputas entabladas con otros actores universitarios de diferente signo político? ¿Qué rol pretendían asumir a partir de su definición como peronistas? ¿Contaban con un nuevo proyecto para la universidad o sólo estaban interesados en los problemas de la revolución, el socialismo y la liberación? A esto se suman otras preguntas sobre el papel de la JUP y ADUP en la tercera etapa de gobierno peronista ¿Cómo fue su injerencia en la gestión

\footnotetext{
${ }^{63}$ Retomamos esta definición de cuestión universitaria de Sarlo, B., Ob. cit., 2000. Según ella, esta cuestión tiene una faz académica y una ligada a posicionamientos políticos, dado que implica discutir el perfil de la universidad, pero también su relación con la sociedad, la cultura, la ciencia, los intelectuales, los estudiantes, entre otros.
} 
de Puiggrós en la UBA? ¿Tuvieron influencia en la elaboración de la ley universitaria de 1974? ¿Entablaron nuevos debates con otros sectores del peronismo, la izquierda y el radicalismo en este marco?

Frente a este panorama bibliográfico y al conjunto de interrogantes desplegados, la presente tesis pretende profundizar tres ejes de análisis que consideramos centrales en el estudio de la peronización en la UBA entre 1966 y 1974: 1)- El origen, la trayectoria política y la perspectiva político-académica de las principales organizaciones que se identificaron con el peronismo, lo visualizaron como una alternativa revolucionaria y permitieron la conformación de la JUP y la ADUP; 2)- Las características más relevantes de los proyectos de universidad que impulsaron y las controversias que entablaron con otros sectores del campo político-cultural; 3)- El papel de la JUP y ADUP en la definición de las principales políticas y debates universitarios en la etapa que transcurre entre la asunción de Puiggrós como rector interventor de la UBA y la sanción de la ley universitaria de 1974.

El enfoque de investigación propuesto considera necesario un estudio socio-histórico para indagar la génesis y el desarrollo de la peronización universitaria, concibiéndola como una experiencia que intentó definir un modelo alternativo de educación superior en el marco de los procesos conflictivos que envolvieron a la sociedad argentina en los años sesenta y setenta $^{64}$. De esta manera, la respuesta a los interrogantes planteados busca echar luz sobre el heterogéneo campo de la nueva izquierda y mostrar que la politización se desplegó en un amplio abanico de proyectos y estrategias destinadas a producir la renovación de los más diversos ámbitos de la vida social.

\section{IV - OBJETIVOS DE LA TESIS}

Desde los estudios sobre la nueva izquierda argentina, la presente investigación busca contribuir a un mayor conocimiento del proceso de politización que experimentaron las universidades durante los años sesenta y setenta. En el marco de esta problemática, se

\footnotetext{
${ }^{64}$ En relación al interrogante sobre cómo trataron la cuestión universitaria los estudiantes, docentes e intelectuales peronizados de la UBA, compartimos una preocupación similar a la de Osvaldo Graciano. Este autor sostiene que pese a la existencia de una serie de estudios que dan cuenta de segmentos significativos del sistema universitario a lo largo del siglo XX, sigue siendo escaso el interés de la historiografía por las propuestas de reorganización de las casas de estudio, promovidas tanto desde el sistema político como en la misma universidad en la etapa comprendida entre 1918 y 1955. En esta investigación, sostenemos ese mismo diagnóstico para el período 1966-1974, con respecto a los grupos universitarios ligados a la nueva izquierda. Por otra parte, si bien su estudio indaga en la trayectoria de intelectuales reformistas vinculados al PS y al anarquismo en la primera mitad del siglo XX, la intención de reconstruir sus itinerarios articulando proyectos de universidad y participaciones en diversos ámbitos político-académicos, resultó una matriz analítica relevante para esta tesis. Graciano, O., Entre la torre de marfil y el compromiso político. Intelectuales de izquierda en la Argentina 1918-1955, Bernal, UNQUI, 2008.
} 
propone estudiar la peronización de estudiantes, docentes e intelectuales de la UBA, entre la intervención dispuesta por el régimen militar de Onganía y la sanción de la ley universitaria 20.654 en 1974. A partir del objetivo señalado, esta tesis busca desarrollar elementos analíticos y empíricos que permitan explicar las razones por las cuales un conjunto de sectores universitarios tradicionalmente hostiles al peronismo produjeron un vuelvo significativo en sus orientaciones político-académicas, contribuyeron a afianzar una perspectiva radical dentro de dicho movimiento y propusieron proyectos de universidad alternativos tanto al modelo reformista tradicional como a la experiencia académica de los primeros gobiernos de Perón, en el contexto de politización y radicalización de los sesenta y setenta.

Con esta finalidad, nos proponemos abordar a lo largo del trabajo los siguientes objetivos específicos:

1)- Reconstruir la trayectoria política de las principales organizaciones estudiantiles, docentes e intelectuales que se identificaron con el peronismo e influyeron en la transformación de la perspectiva política-académica de varios actores de la UBA entre 1966 y 1973, tales como el FEN, la UNE, las CN, entre otros.

2)- Identificar los ámbitos de discusión donde intervinieron los agrupamientos estudiantiles, docentes e intelectuales para definir sus visiones sobre la universidad frente a otros actores del campo político-cultural, haciendo hincapié en las revistas Antropología 3er. Mundo y Envido, como también en los diagnósticos sobre la experiencia universitaria del primer peronismo y en las críticas a los legados de la Reforma Universitaria de 1918.

3)- Indagar el surgimiento de la JUP y la ADUP en el marco de la consolidación de la Tendencia Revolucionaria del peronismo y la asunción presidencial de Cámpora, identificando las principales organizaciones que confluyeron en sus filas, los proyectos de universidad propuestos y los debates que mantuvieron con organizaciones del radicalismo y la izquierda, como el MOR de la Federación Juvenil Comunista y FM de la Juventud Radical.

4)- Analizar el papel de la JUP y ADUP en la gestión de Puiggrós como rector interventor de la UBA y en los debates que antecedieron a la sanción de la ley universitaria 20.654, durante el último gobierno de Perón.

\section{V - HIPÓTESIS, REFERENCIAS CONCEPTUALES E HISTORIOGRÁFICAS}

La presente investigación esboza como punto de partida tres hipótesis generales para guiar el análisis del conjunto de problemáticas delimitadas en el proceso histórico abordado. La primera plantea que la peronización de estudiantes, docentes e intelectuales de la UBA fue una manifestación relevante de la politización de los sesenta. A los pocos años de la 
intervención universitaria de 1966, surgieron nuevas experiencias organizativas que progresivamente reconocieron al peronismo como eje de su trabajo político-académico y lo interpretaron como una alternativa legítima para encarar transformaciones revolucionarias. Este itinerario implicó la resignificación de viejas identidades reformistas y católicas, junto a la constitución de nuevos referentes para superar lo que era considerado un desencuentro trágico entre sectores medios y trabajadores. Sin embargo, este cambio no habría sido posible si en el período previo a 1966, los principales integrantes de estos grupos no hubieran abandonado sus posturas antiperonistas, en un escenario signado por la influencia de la Revolución Cubana, el Concilio Vaticano II y la incipiente formación de una nueva izquierda política, social y cultural.

La segunda hipótesis señala que la presencia político-partidaria de las organizaciones peronizadas fue acompañada, hacia fines de los sesenta y principios de los setenta, por una revalorización de la cuestión universitaria. Si entre mediados de los cincuenta y sesenta, el objetivo central de los agrupamientos peronistas había consistido en acercar a los estudiantes a la lucha contra la proscripción y a demandas políticas que excedían al campo académico -dejando de lado sus reivindicaciones gremiales y las políticas universitarias-; esa perspectiva se iría modificando gradualmente en los años siguientes. La peronización de nuevos actores implicó una revalorización de la universidad como un espacio de militancia legítimo que debía contar con discursos y medidas específicas. Las revistas Antropología 3er. Mundo y Envido funcionaron como centros de producción de controversias político-culturales donde intervinieron estudiantes, docentes e intelectuales. Los debates no se reducían a problemas político-ideológicos generales, como la lucha armada, el papel del peronismo y la izquierda. También involucraban discusiones sobre el rol del movimiento estudiantil, los intelectuales y la universidad.

La última hipótesis de trabajo considera que la peronización porteña se complejizó con la conformación de la JUP y la ADUP, en el marco de la retirada de la dictadura militar y la asunción presidencial de Cámpora. Estas transformaciones impulsaron una politización específica que aludía directamente a partidos y a vertientes radicalizadas de la escena nacional. Las organizaciones universitarias de la Tendencia Revolucionaria del peronismo tuvieron injerencia en la gestión de Puiggrós como rector interventor de la UBA y en la sanción de la ley universitaria de 1974. Esta situación produjo un conjunto de discursos que esbozaron un proyecto alternativo de educación superior, diferenciado del reformismo tradicional como de la experiencia académica de los primeros gobiernos de Perón. A su vez, este nuevo contexto dinamizó un espacio inédito de debate entre distintas facciones del 
movimiento peronista y otros sectores vinculados a la izquierda y el radicalismo, como FM y el MOR.

El desarrollo de las hipótesis señaladas debe tener en cuenta una serie de referencias conceptuales e historiográficas de estudios especializados que articulan elementos de la política, la sociedad y la cultura. Un primer conjunto alude a la relación entre politización, radicalización y partidización. Los tres conceptos son una clave relevante para definir cómo se desenvolvió la relación entre universidad y peronismo a lo largo del período. Terán sentó las bases de un enfoque que plantea que los cruces entre tendencias modernizadoras y revolucionarias permitieron la formación de una nueva izquierda cultural que progresivamente subsumió las prácticas intelectuales y culturales a la lógica de la dinámica política $^{65}$. Por su parte, Sigal sostiene que se produjo una creciente partidización de las perspectivas de la comunidad académica desde que Onganía intentó prohibir la política en el interior de las casas de estudio. Los estudiantes, docentes e intelectuales habrían dejado de definirse a partir de la pertenencia a la universidad, la adhesión a la Reforma o a través de una identidad que remitía a principios generales como el humanismo, para hacerlo en función de una determinada organización político-partidaria ${ }^{66}$. Desde estas perspectivas, el estudio en profundidad de las experiencias de peronización puede brindar un panorama más variado y complejo, en el cual se distingan distintos matices y tensiones entre los procesos de politización, radicalización y partidización.

Un segundo conjunto de referencias conceptuales e historiográficas está vinculado al tratamiento de la cuestión universitaria. La problemática no puede prescindir de las claves analíticas que propone Sarlo. Para la autora, la universidad argentina fue animada cinco veces por una idea de refundación en el curso de treinta años: durante el primer peronismo, la "Revolución Libertadora”, el golpe de Onganía, la efímera presidencia de Cámpora y el gobierno de Isabel Perón, el cual anticipó el carácter represivo de la dictadura cívico-militar de $1976^{67}$. En este encuadre histórico, Sarlo retoma el enfoque interpretativo de Terán cuando argumenta que la conformación de la nueva izquierda y la incorporación de capas medias al peronismo revolucionario generaron las condiciones para disolver la cuestión universitaria en problemáticas estrictamente políticas. De esta manera, desde mediados de los sesenta el debate político habría capturado casi todos los espacios e impuesto su dinámica de funcionamiento $^{68}$. A la luz de los procesos históricos que serán reconstruidos y analizados,

\footnotetext{
${ }^{65}$ Terán, Ob. cit., 1991, p.171.

${ }^{66}$ Sigal, S., Ob. cit., 1991, p. 71.

${ }^{67}$ Sarlo, B., Ob. cit., 2001, pp. 85-87.

${ }^{68}$ Ibídem, p. 91.
} 
esta investigación se propone volver a interrogar el "fin de la cuestión universitaria".

Finalmente, el examen de los ámbitos de debate donde intervinieron estudiantes, docentes e intelectuales para definir discursos sobre la universidad debe retomar un conjunto de referencias conceptuales e historiográficas que hacen alusión al movimiento de la Reforma Universitaria y a corrientes críticas del mismo. El clásico trabajo de Portantiero plantea que desde las protestas estudiantiles de 1918, el reformismo representó no sólo un proyecto de universidad basado en la autonomía, el cogobierno, la libertad de cátedra y el laicismo, sino el ideario de amplias franjas de jóvenes, ligado a elementos clave como el americanismo, el antiimperialismo, el anticlericalismo y el juvenilismo. No obstante, esta escuela ideológica se habría bifurcado tempranamente en dos corrientes poco conectadas entre sí: los movimientos populares antiimperialistas y el socialismo internacionalista. A partir de entonces, quedaron clausuradas las posibilidades de acuerdo entre los herederos de la Reforma y América Latina asistiría al permanente antagonismo entre perspectivas nacional-populares y revolucionarias ${ }^{69}$.

Más recientemente, Diego Pereyra propone una clasificación que distingue una tradición crítica de los legados de la Reforma, inspirada en la producción intelectual de la Fuerza de Orientación Radical de la Joven Argentina (FORJA) y en la valorización de la política universitaria de los primeros gobiernos peronistas. Esta perspectiva cuestionaba al reformismo por haber "traicionado" el sentido transformador de sus orígenes, denunciaba que la autonomía terminó aislando a la universidad de las necesidades del país e interpretaba que la democratización de dicho espacio dependía de la capacidad de integrar a los sectores populares. Por esta razón, otorgaba importancia a las políticas que buscaban expandir la matrícula, incorporar mecanismos de control estatal y de mayor compromiso social ${ }^{70}$.

Por su parte, Sigal otorga elementos para indagar cómo fueron resignificadas estas experiencias universitarias en los años sesenta y setenta. La autora señala que los aspectos académicos y político-ideológicos de la Reforma se modificaron históricamente, en función de coyunturas específicas y de controversias que atravesó el espacio político-universitario. De esta manera, se constituyó como una doctrina siempre mixta, de naturaleza política como cultural, con un claro referente institucional -la universidad-, pero con borrosos límites ideológicos. Esta situación le permitió adquirir distintos significados, identificar adversarios, nombrar partidarios y aglutinar a diversas fuerzas en su interior ${ }^{71}$. En el marco historiográfico y analítico descripto, la presente investigación busca rastrear cómo reinterpretaron los

\footnotetext{
${ }^{69}$ Portantiero, J.C., Estudiantes y política en América Latina, México, Siglo XXI, 1978.

70 Pereyra, D., "La Reforma universitaria en Argentina. Antecedentes, problemas y desafíos", en Toribio, D. (comp.), en La universidad en la Argentina: miradas sobre su evolución y perspectivas, UNLA, 2010, p. 111.

${ }^{71}$ Sigal, S., Ob. cit., 1991, p. 73-74.
} 
principios reformistas los núcleos estudiantiles, docentes e intelectuales que atravesaron un proceso de peronización, además de preguntarnos cuáles fueron los aspectos revalorizados del modelo universitario del primer peronismo.

El conjunto de hipótesis, referencias conceptuales e historiográficas de los párrafos anteriores permiten delinear una serie de problemáticas fundamentales del proceso sociopolítico estudiado. Sin embargo, esos elementos no son entendidos como puntos de partida cristalizados, sino como parte de un marco analítico que necesita ser complejizado durante el desarrollo de la investigación.

\section{VI - Metodología}

De acuerdo al problema y los objetivos delimitados, esta tesis implementa un diseño de investigación flexible centrado en una estrategia metodológica cualitativa. Por esta razón, utiliza dos técnicas para la construcción de datos: las entrevistas en profundidad semiestructuradas y el análisis de fuentes documentales escritas de diverso orden.

Como señala la bibliografía especializada, las entrevistas son una herramienta metodológica privilegiada para aproximarse al sentido que los actores le atribuyeron a sus prácticas y discursos, además de permitir la reconstrucción de procesos y acontecimientos sobre los que se carece de otro tipo de fuentes ${ }^{72}$. En esta investigación, seleccionamos a partir de un muestro intencional a un conjunto de antiguos estudiantes, docentes, intelectuales, militantes y funcionarios de la UBA que fueron protagonistas o testigos de la experiencia analizada. Aplicamos el muestreo bola de nieve, con la finalidad de acceder a estos entrevistados mediante redes de contactos iniciales. Para comprender la trama argumental, teórica y política que facilitó su identificación con el peronismo y el diálogo que mantuvieron con otros actores sociales, políticos y culturales de la época, realizamos 40 entrevistas a 34 testimoniantes distintos. Las mismas comprenden a ex integrantes de: a)- agrupaciones estudiantiles peronistas, como el FEN, UNE, CENAP, CEP, FANDEP, JAEN, FORPE y JUP; b)- grupos docentes e intelectuales de ese mismo signo político, como las CN y ADUP; c)funcionarios de la gestión de Puiggrós en la UBA en 1973; y d)- sectores docentes, estudiantiles e intelectuales pertenecientes a la izquierda y el radicalismo que entablaron

\footnotetext{
${ }^{72}$ Alonso, L., La mirada cualitativa en sociología, Madrid, Fundamentos, 1988; Piovani, J. I., "La entrevista en profundidad”, en Marradi, A., Archenti, N. y Piovani, J. I., Metodología de las ciencias sociales, Bs. As., Emecé, 2007; Carnovale, V., "Aportes y problemas de los testimonios en la reconstrucción del pasado reciente en la Argentina”, en Franco, M. y Levín, F. (comps.), Historia reciente. Perspectivas y desafíos para un campo en construcción, Bs. As., Paidós, 2007.
} 
discusiones con el peronismo universitario ${ }^{73}$. A su vez, recolectamos entrevistas y testimonios autocríticos de protagonistas de la época disponibles en bibliografía y repositorios institucionales de distinto tipo ${ }^{74}$.

En esta tesis las entrevistas tienen una importancia central para reconstruir las trayectorias de los actores estudiados a partir de un enfoque socio-histórico ${ }^{75}$. Como plantea Theda Skocpol, dicha perspectiva introduce la dimensión cronológica de las experiencias políticas y sociales, al concebirlas en una línea de tiempo donde se entretejen un conjunto variable de trayectos que traen aparejados continuidades y rupturas ${ }^{76}$. Sin pretender agotar todas las instancias de estudio, podemos señalar que el examen de trayectorias es una aproximación teórico-metodológica que permite indagar cómo los itinerarios individuales se inscriben en el marco de diferentes tipos de relaciones sociales y en la composición de múltiples colectivos. De esta manera, la reconstrucción de la trayectoria de estudiantes, docentes e intelectuales busca vislumbrar el origen, los posicionamientos y discursos de las principales organizaciones que se referenciaron con el peronismo, así como identificar los proyectos de universidad impulsados desde sus filas; concibiendo a la casas de estudio como la expresión de un conjunto de luchas entre un sinfín de articulaciones sociales que involucraron actores, representaciones y coyunturas de diversa índole ${ }^{77}$.

A su vez, es importante tener en cuenta que las entrevistas realizadas en investigaciones socio-históricas conllevan dificultades específicas vinculadas a los usos políticos del pasado y a las condiciones sociales que posibilitan que ciertas experiencias sean

\footnotetext{
${ }^{73}$ Se puede consultar el listado de entrevistas realizadas en la parte final de la tesis, pp. 256-257.

${ }^{74}$ A lo largo de la tesis vamos a citar trabajos de protagonistas de la época donde pueden encontrarse testimonios y análisis sobre las experiencias que vivenciaron. Sin agotar ahora el listado, entre ellos pueden mencionarse: Feinmann, J. P., y González, H., Historia y pasión: la voluntad de pensarlo todo, Bs. As., Planeta, 2013; Bárbaro, J., Juicio a los 70, Bs. As., Sudamericana, 2009; Puiggrós, A., Rodolfo Puiggrós: retrato familiar de un intelectual militante, Bs. As., Taurus, 2010; Grabois, R., Memorias de Roberto Pajarito Grabois: de Alfredo Palacios a Juan Perón (1955-1974), CABA, Corregidor, 2014; Sadi, M., La resistencia después del final, Bs. As., Nuevos Tiempos, 2004. Mención aparte merecen los trabajos de Baschetti, dedicados a reconstruir la biografía de los militantes del período y recopilar documentación del peronismo universitario: Baschetti, R., $L a$ memoria de los de abajo 1945-2007, La Plata, De la Campana, 2007, Tomo I y Tomo II; Baschetti, R., Peronistas que estudian. De los libros de lectura a la lectura de la realidad, Bs. As., Jironesdemivida, 2016. Además, pueden encontrarse entrevistas en la biblioteca digital Trapalanda de la Biblioteca Nacional de la República Argentina "Mariano Moreno", en el Centro de Documentación y Archivos de Memoria Abierta y en el ciclo de programas televisivos Somos Memoria que coordinó el Centro Cultural de la Memoria Haroldo Conti junto a Canal Encuentro.

${ }^{75}$ Noirel, G., Introducción a la sociohistoria, España, Siglo XXI, 2011; Offerlé, M., Perímetros de lo politico: contribuciones a una socio-historia de la política, Bs. As., Antropofagia, 2011.

${ }^{76}$ Skocpol, T., "Estrategias recurrentes y nuevas agendas en sociología histórica”, en Ansaldi, W. (comp.), Historia, Sociología, Sociología histórica, Bs. As., CEAL, 1994.

${ }^{77}$ Mallimaci, F. y Giménez Beliveau, V., "Historia de vida y métodos biográficos", en Vasilachis de Gialdino, I., Estrategias cualitativas de investigación, Bs. As., Gedisa, 2007; Donatello, L. M., "Religión y política: las redes sociales del catolicismo post -conciliar y los Montoneros, 1966-1973", en Estudios Sociales, No 24, Centro de Publicaciones de la Universidad Nacional del Litoral, Santa Fe, primer semestre 2003.
} 
narradas, signando los recuerdos, olvidos y silencios de los testimonios. Se trata de los problemas relativos a la construcción de la memoria individual y colectiva ${ }^{78}$. Dado que la relación entre el presente de los entrevistados y su pasado militante no forma parte del objeto específico de esta tesis, esas cuestiones fueron consideradas en términos metodológicos, conjugando el análisis de los testimonios con otro tipo de fuentes o bien con otras entrevistas cuando ello no fue posible.

La segunda técnica de reconstrucción de datos utilizada en esta investigación, es el análisis de fuentes secundarias escritas ${ }^{79}$. Entre ellas, otorgamos un papel relevante a diarios y revistas de alcance nacional, como La Prensa, La Razón, La Opinión, La Nación, Clarín, Noticias, Panorama y Primera Plana. Estos materiales otorgan elementos para estimar el grado de relevancia pública de los actores, los grupos y los debates estudiados. A su vez, para analizar las controversias sobre la cuestión universitaria tenemos en cuenta especialmente revistas político-culturales de jóvenes docentes e intelectuales peronistas de la UBA, como Antropología 3er. Mundo y Envido. En este punto, es relevante considerar que mientras los diarios intentan formar opinión a través de la trasmisión de información, el objetivo de las revistas está puesto centralmente en debatir y confrontar ideas. A lo que se suma, que estos emprendimientos suelen ser expresión de grupos intelectuales, estudiantiles o políticos con trayectorias más o menos homogéneas, pero que se inscriben en una trama más amplia de actores y discusiones ${ }^{80}$.

Por esta razón, a lo largo del trabajo también vamos a tener en cuenta publicaciones de otras vertientes intelectuales de izquierda, como Los Libros, e incluso documentos de una agrupación de derecha como la Concentración Nacional Universitaria (CNU). También, dado que las discusiones se replicaron en otros ámbitos político-culturales no específicamente universitarios, recopilamos una serie de publicaciones político-periodísticas, políticointelectuales e incluso político-profesionales, como el Semanario CGT, El Descamisado, Gobierno Peronista, Cristianismo y Revolución, Militancia Peronista para la Liberación, El

\footnotetext{
${ }^{78}$ Portelli, A., "Lo que hace diferente a la historia oral", en Schwarzstein, D. (comp.), La historia oral, Bs. As., CEAL, 1991; Pollak, M., "Memoria e identidad social", en Memoria, olvido, silencio, Al margen, La Plata, 2006; Pollak, M. y Heinch, N., "El testimonio", en Ob. cit., 2006.

${ }^{79}$ Valles, M., "La investigación documental: técnicas de lectura y documentación”, en Técnicas cualitativas de investigación social. Reflexión metodológica y práctica profesional, Madrid, Síntesis, 1997.

${ }^{80}$ Para abordar la utilidad de las revistas político-culturales en la reconstrucción de grupos y debates universitarios, puede consultarse: Suasnábar, Ob. cit, 2004; Altamirano, C., y Sarlo, B., Literatura/Sociedad, Bs. As., Edicial, 1993. Estos últimos autores sintetizan en la siguiente frase la concepción sobre las revistas que privilegiamos en este trabajo: "Ético o estético, teórico o político, el círculo que una revista traza para señalar el lugar que ocupa o aspira a ocupar marca también la toma de distancia, más o menos polémica, respecto de otras posiciones incluidas en el territorio [...] Otro rasgo inherente a la forma revista es que ésta habitualmente traduce una estrategia de grupo". Ibídem, pp. 96-97.
} 
Caudillo, Movimiento, Bandera Roja, Las Bases, Ciencia Nueva, Peronismo y Liberación, entre otras. Por último, tuvimos en cuenta una serie de documentos institucionales: planes de estudio, resoluciones del rectorado y revistas de la UBA, como Aportes para la Nueva Universidad. Además del texto legal de la ley universitaria 20.654 y los debates parlamentarios que involucraron a la misma ${ }^{81}$.

Para una adecuada interpretación de las fuentes consideramos el análisis del contexto social de su producción, sus destinatarios presuntos o reales, sus formas de expresión y las posiciones de sus narradores ${ }^{82}$. La mayoría de la documentación propuesta está disponible en los siguientes establecimientos y repositorios digitales: Centro de Documentación e Investigación de la Cultura de Izquierdas (CeDInCI); Comisión Provincial por la Memoria; Archivo de la Facultad de Filosofía y Letras de la UBA; Hemeroteca de la Biblioteca Nacional, de la Legislatura de Buenos Aires y de la UNLP; el Centro de Documentación y Archivos de Memoria Abierta; Ruinas Digitales; el Topo Blindado, entre otros.

\section{VII - ESTRUCTURA DE LA TESIS}

La complementariedad de las estrategias metodológicas seleccionadas parte de un enfoque analítico que relaciona la coyuntura político-social de los sesenta con la trayectoria y la perspectiva político-académica de los estudiantes, docentes e intelectuales de la UBA involucrados en el proceso de peronización. Uno de los ejes centrales del estudio supone que los conflictos universitarios deben entenderse como una experiencia compleja, donde los debates internos de las casas de estudio se articularon con el escenario político, social y cultural de esos años. Por esta razón, requieren analizarse en el marco de los interrogantes y dilemas de una época signada por la politización del campo cultural. Como sostiene Sigal, la reiterada interferencia del poder político en las instituciones culturales argentinas justifica tomar como punto de partida la distinción entre la esfera política y la esfera cultural como sistemas claramente diferenciados de manera de examinar la relación y los cruces entre $\operatorname{ambas}^{83}$. De esta manera, el examen histórico de los procesos políticos vinculados a la universidad necesita cumplir dos requisitos: reconstruir la historia interna de las instituciones y analizar los escenarios socio-políticos en los que ella está inscripta.

Partiendo de esta perspectiva, la presente tesis está organizada en tres partes que

\footnotetext{
${ }^{81}$ Asimismo, la reconstrucción de las principales políticas de la gestión de Puiggrós no puede prescindir de una compilación de entrevistas y discursos que realizó el rector-interventor durante su mandato. Puiggrós, R., La universidad del pueblo, Bs. As., Crisis, 1974.

${ }^{82}$ Combessie, J. C., El método en sociología, Córdoba, Ferreira Editor, 2005; Pollak, M. y Heinch, N., Ob. cit., 2006.

${ }^{83}$ Sigal, S., Ob. cit., 1991, pp.16-18.
} 
contienen cinco capítulos. Para delimitar el tratamiento temático de cada uno, tomamos como referencia cuestiones universitarias y hechos político-culturales más amplios. En el primer capítulo titulado "Los inicios de la peronización" reconstruimos los nuevos grupos peronistas que surgieron en la UBA, entre el golpe de Estado de 1966 y la desaparición de la CGT de los Argentinos en 1970. Luego de un apartado introductorio referido a cómo algunos protagonistas de la época interpretaron la intervención universitaria decretada por el régimen militar de Onganía, repasamos las agrupaciones estudiantiles que tramitaron su pasaje al peronismo con posterioridad a ese hecho, pero prestando atención a la trayectoria previa de sus principales dirigentes y militantes. Después, analizamos cómo entendían al peronismo y el papel clave que jugó la CGT de los Argentinos en este tema. Por último, indagamos la trayectoria de los integrantes de las $\mathrm{CN}$ de la Facultad de Filosofía y Letras y su influencia en la peronización de universitarios porteños.

El segundo capítulo se titula "En busca de un relato para la universidad". En esta parte de la tesis indagamos la manera en que abordaron la cuestión universitaria los grupos de estudiantes, docentes e intelectuales peronizados entre mediados de los años sesenta y principios de la década siguiente. Comenzamos con una introducción sobre cómo interpretaron algunos intelectuales de la época la disolución del viejo desencuentro entre peronismo y universidad. Luego tomamos como referencia a la revista Antropología 3er. Mundo para analizar los debates sobre la cuestión universitaria que entablaron peronistas con otros actores académicos, políticos y culturales de aquel entonces; haciendo hincapié en la significación particular que otorgaron a la Reforma de 1918 y a la gestión universitaria del primer peronismo. La periodización de este capítulo tiene dos momentos importantes: la aparición de Antropología 3er. Mundo en 1968 y la desaparición de las CN junto a la irrupción de los cuerpos de delegados en la UBA a principios de la década siguiente.

En el tercer capítulo denominado "La peronización en los albores de la primavera camporista", abordamos la manera en que se canalizaron organizativamente las experiencias de peronización de universitarios porteños a principios de los setenta. Luego de una introducción referida a cómo interpretaron algunos intelectuales de la época el contexto expectante que generó el retorno de Perón a la Argentina en 1972 y la elección de Cámpora como nuevo presidente constitucional en 1973; analizamos la constitución de la JUP, tomando como antecedente inmediato al proceso de unificación de las Juventudes Peronistas y el surgimiento de la Coordinadora Universitaria Peronista. Finalmente, reconstruimos el escenario político en el que se enmarcó la designación de Puiggrós como nuevo rector interventor de la UBA el 29 de mayo de 1973, para indagar de dónde provenía la base de 
docentes e intelectuales sobre la que partió su gestión.

El cuarto capítulo se titula "Un proyecto para la universidad" y analiza cómo debatieron la cuestión universitaria los grupos porteños de estudiantes, docentes e intelectuales que se orientaron al peronismo de izquierda a principios de los setenta. Luego de una introducción referida al modo en que Puiggrós y José María Rosa interpretaron en aquel entonces la relación entre el peronismo y los universitarios, reconstruimos la trayectoria de los principales integrantes de la revista Envido. Después tomamos como referencia a esta publicación para indagar si la creación de la JUP y la ADUP trajo consigo la elaboración de una propuesta concreta para definir los fines, la estructura y la organización de las casas de estudio. Por último, analizamos cómo en 1972-73 el peronismo de izquierda formó parte de una red más amplia de revistas, diarios, libros y editoriales, donde un conjunto de actores de diverso signo político diagnosticaban la crisis de la universidad argentina y sugerían distintas recetas para solucionarla.

Finalmente, en el quinto capítulo "El auge y ocaso de la peronización porteña" examinamos los posicionamientos de los grupos estudiantiles, docentes e intelectuales que se identificaron con el peronismo de izquierda en el contexto político-académico que siguió a la elección de Cámpora como presidente y de Puiggrós como interventor de la UBA. Luego de un apartado inicial referido al modo en que distintos actores de la época diagnosticaron la llegada de Puiggrós al rectorado y la refundación de la casa de estudio como la "Universidad Nacional y Popular de Buenos Aires", reconstruimos el respaldo que brindó la JUP y ADUP a su gestión. A su vez, indagamos si el peronismo de aquel entonces congregó una adhesión importante en la población universitaria, teniendo en cuenta la participación de la JUP en las elecciones estudiantiles. Por último, abordamos las controversias que surgieron en torno a la sanción de la Ley Taiana, con la intención de analizar los debates que entablaron la JUP y ADUP con otros sectores del peronismo, la izquierda y el radicalismo.

Luego de los cinco capítulos descriptos, concluimos el trabajo con una recopilación de los principales aportes analíticos y empíricos que desarrollamos en la tesis, esperando generar nuevos interrogantes y líneas de investigación a ser profundizadas en futuros estudios. 


\section{LOS INICIOS DE LA PERONIZACIÓN}

\section{Del golpe de Onganía a la CGT de los Argentinos}

1966 - 1970

En este primer capítulo reconstruimos los nuevos grupos universitarios peronistas que surgieron en la UBA entre el golpe de Estado de 1966 y la desaparición de la CGT de los Argentinos en 1970. Luego de una introducción referida a cómo algunos protagonistas de la época interpretaron la intervención universitaria decretada por el régimen militar, repasamos las agrupaciones estudiantiles que tramitaron su pasaje al peronismo con posterioridad a ese hecho, pero prestando atención a la trayectoria previa de sus principales dirigentes y militantes. Después, analizamos cómo entendían al peronismo y el papel clave que jugó la CGT de los Argentinos en este tema. Por último, indagamos la trayectoria de los integrantes de las Cátedras Nacionales de la Facultad de Filosofía y Letras y su influencia en la peronización de universitarios porteños.

\section{I - LA NOCHE DE LOS BASTONES LARGOS}

El 28 de junio de 1966 un destacamento de policías de la guardia de infantería expulsó al presidente Arturo Illia de la Casa Rosada. La segunda experiencia de gobierno civil emprendida desde el derrocamiento del peronismo llegaba a su fin y los militares intervenían nuevamente en la política Argentina. A nadie le llamó la atención que al día siguiente asumiera la presidencia el general Juan Carlos Onganía. La destitución de la administración de la Unión Cívica Radical del Pueblo venía discutiéndose públicamente desde hacía tiempo y contó con un respaldo social, político y mediático importante. El poderoso líder de la Unión Obrera Metalúrgica (UOM), Augusto Timoteo Vandor, acudió a la asunción de Onganía e incluso el gran excluido de la política argentina brindó ese mismo día una entrevista exclusiva a Primera Plana donde caracterizaba a los artífices de la destitución de Illia como un "movimiento simpático" que cerraba una etapa de "verdadera corrupción". Aunque Juan Domingo Perón le aclaraba al periodista Tomás Eloy Martínez que eso no significaba entregarle un "cheque en blanco", ya que esperaba que el nuevo presidente aprovechara la 
"última oportunidad" que tenía la Argentina para evitar una "guerra civil" y retornar en un corto período a un régimen de elecciones libres sin proscripciones ${ }^{84}$.

En este contexto expectante, la UBA fue la única institución pública en poner reparos contra el golpe. Mediante una declaración, el rector humanista Hilario Fernández Long junto a la mayoría del Consejo Superior calificó al 28 de junio como un "día aciago" y llamó a la defensa de la autonomía universitaria ${ }^{85}$. La reacción fue inmediata, a un mes de esas declaraciones el régimen militar intervino las universidades nacionales mediante el decretoley 16.912 y desalojó violentamente a las facultades porteñas que habían sido tomadas en señal de protesta. La de Ciencias Exactas fue la que contó con el mayor número de heridos y detenidos. Sergio Morero, el cronista de noticias universitarias de Primera Plana, nominó a los sucesos como "La noche de los bastones largos" porque en ese momento le habían hecho recordar a "La noche de los cuchillos largos", la serie de purgas y asesinatos políticos que llevó adelante el Partido Nacionalsocialista Obrero Alemán en $1934^{86}$. Desde ya que hubo una distancia enorme entre los dos acontecimientos. Todos los estudiantes y docentes porteños encarcelados el 29 de julio, recuperaron su libertad al poco tiempo del operativo policial. Pero retomamos esta nominación que pasó a la historia para dar cuenta de una característica que tuvo la intervención en la UBA: contó con una gran repercusión pública y desató una inmensa cantidad de opiniones e interpretaciones de lo sucedido en distintos actores del campo político, social y cultural argentino.

Al principio, los que intentaron hacer más visibles sus pareces fueron los sectores directamente afectados con la nueva situación. Un mes después de la normativa de Onganía que suprimió la autonomía y el gobierno tripartito, el reconocido reformista Risieri Frondizi, quien había sido rector de la UBA entre 1957 y 1962, calificó públicamente a esos hechos como "la crisis universitaria más grave desde la época de Rosas". A su entender, "jamás habían renunciado tantos profesores" y encima habían "destruido con torpeza" la obra de "modernización académica" que ellos mismos habían iniciado a fines de los cincuenta ${ }^{87}$. En la misma semana de septiembre en que Frondizi brindó sus declaraciones a Primera Plana, la Federación Universitaria Argentina (FUA) convocó a una movilización nacional en Córdoba para amplificar las protestas. La manifestación se llevó acabo el día 7, pero fue reprimida y produjo la muerte del militante estudiantil Santiago Pampillón. Desde el mes de octubre la

\footnotetext{
84 "Perón: tres horas con Primera Plana”, en Primera Plana, Edición Especial, 30 de junio 1966.

85 "Declaración de la Universidad de Buenos Aires", 28 de junio 1966. Se puede consultar el documento en: Baschetti, R., Peronistas que estudian. De los libros de lectura a la lectura de la realidad, Bs.As., Jironesdemivida, 2016, p.144.

${ }^{86}$ Morero, S., La noche de los bastones largos 30 años después, Bs.As., Documentos Pagina 12, 1996, p.5.

87 “Declaraciones del Dr. Risieri Frondizi”, en Primera Plana, № 193, 6-12 de septiembre 1966.
} 
oposición universitaria comenzó su declive y en abril del año siguiente Onganía finalmente decretó una nueva ley universitaria (17.245) que prohibía cualquier tipo de actividad política en las aulas.

Entre fines de los sesenta y principios de los setenta, se reactivó la oposición universitaria en medio de las grandes protestas populares contra la dictadura y la proliferación de actores políticos, sociales y culturales que reclamaban salidas revolucionarias. En ese marco, comenzaron a hacerse visibles un conjunto de interpretaciones sobre la intervención de 1966 que resaltaban aspectos positivos de la misma, a pesar de provenir de opositores a Onganía. Un año antes del Cordobazo, el Grupo Cine Liberación proyectó La Hora de los Hornos en Italia, un documental político con fuertes críticas al régimen militar que fue premiado internacionalmente y circuló ampliamente en el país de manera clandestina. En el film, Julio Bárbaro, el presidente de La Liga Humanista de Buenos Aires, sostenía que el golpe de Estado había terminado "aportando al proceso revolucionario" porque obligó a los universitarios a salir de su "isla" y a encontrarse con el peronismo en la proscripción ${ }^{88}$. Unos años después, esta misma idea fue repetida y mejor explicitada por Alcira Argumedo, una docente que había sido militante reformista y en ese entonces era parte de las Cátedras Nacionales de la Facultad de Filosofía y Letras. A su entender, la intervención de Onganía hizo más por una "politización real" de los universitarios que "50 años de Reforma", debido a que desde 1966 se había acabado su "isla democrática” y habían comenzado a confluir con el movimiento peronista ${ }^{89}$.

Estas últimas interpretaciones llamaban la atención porque eran realizadas por una docente y un estudiante que provenían del reformismo y el humanismo, dos sectores que no sólo habían sido activos militantes del golpe de Estado contra Perón en 1955, sino que incluso sus principales referentes en la UBA, como Frondizi y Fernández Long, habían rechazado fuertemente la intervención universitaria en 1966. Pero más allá de las valoraciones que realizaban los protagonistas de la época y de otro sinfín de voces que pueden encontrarse en aquellos años, tomamos como punto de partida estos relatos para preguntarnos por la peronización de estudiantes, docentes e intelectuales porteños en la etapa que siguió a la llegada de Onganía al poder ¿Qué magnitud tuvo ese pasaje al peronismo? ¿Fue un proceso ampliamente difundido o estuvo acatado a ciertos sectores particulares? ¿Comenzó a partir de 1966 como señalan algunos relatos de época o puede rastrearse antecedentes en años

\footnotetext{
${ }^{88}$ Solanas, F., y Getino, O., La Hora de los Hornos, Grupo Cine Liberación, 1968.

${ }^{89}$ Argumedo, A., "Cátedras Nacionales: una experiencia peronista en la Universidad", en Envido, № 3, abril 1971, p.56.
} 
anteriores? ¿Existieron organizaciones estudiantiles o grupos de docentes e intelectuales que canalizaron esa experiencia? ¿De qué espacios procedían esos estudiantes, docentes e intelectuales peronizados? ¿Cómo entendían al peronismo y cuáles eran sus posicionamientos políticos? ¿Con qué actores concretos del movimiento peronista tenían relaciones?

\section{II - NUEVOS ESTUDIANTES PERONISTAS EN LA UBA}

Durante el primer peronismo habían naufragado los intentos de generar una organización política del estudiantado que sea capaz de disputar el histórico predominio reformista de la FUA y la FUBA. A fines de los cuarenta, Antonio Cafiero y otros alumnos enrolados en el nacionalismo católico fracasaron en su plan de asentar la Federación General de Estudiantes Peronistas. La misma suerte corrió, unos años después, la creación por impulso oficial de la Confederación General Universitaria (CGU). Esta organización surgida a fines de noviembre de 1950 se definía a sí misma como una entidad juvenil, sindical, federal, asistencial, cristiana y revolucionaria. En su órgano de prensa Actitud. Periódico de la juventud argentina mostraba una fuerte impronta anticomunista y católica. La CGU desarrolló principalmente actividades gremiales y participó en los órganos de gobierno de las casas de estudio, por ser la única entidad reconocida al amparo de la ley universitaria de 1954. Sin embargo, y a pesar del respaldo oficial, tuvo una pobre representatividad en la UBA donde no logró hacer mella a la hegemonía y a la militancia opositora del movimiento reformista. El derrocamiento del peronismo gobernante terminó sellando su extinción ${ }^{90}$.

En la primera mitad de los sesenta tampoco corrió mejor suerte el peronismo en la UBA, aunque cambió su tonalidad política en el marco de los grupos juveniles que aparecieron al poco tiempo de la proscripción. El más conocido de ellos fue el de "Corrientes y Esmeralda", integrado por Envar El Kadri, Jorge Rulli, Susana Valle, Gustavo Rearte, Héctor Spina, entre otros. Estos distintos núcleos encararon un lento proceso de convergencia que derivó en la creación de la Mesa Ejecutiva de la Juventud Peronista en 1959 ${ }^{91}$. Bajo este antecedente, surgieron en algunas facultades grupos peronistas referenciados en la sigla ANDE: Agrupación Nacional de Estudiantes. Con la finalidad de coordinarlas, nació la Juventud Universitaria Peronista (JUP) en 1962. Esta experiencia de enlace fue efímera, pero

\footnotetext{
${ }^{90} \mathrm{La}$ CGU tuvo escasa representatividad en las grandes universidades de Buenos Aires y La Plata, aunque la exigua bibliografía sobre el tema destaca una presencia más aceptable en el interior del país. Acha, O. Los muchachos peronistas. Orígenes olvidados de la Juventud Peronista (1945-1955), Bs. As., Planeta, 2011, pp. 77-84; Panella, C., "Actitud: un periódico nacionalista para los estudiantes universitarios peronistas", XIV Jornadas Interescuelas/Departamentos de Historia, Facultad de FFyL, UNCUYO, 2013.

91 Acha, O., Ob. cit., 2011, p. 25. La investigación de Acha discute que la primera JP haya surgido con posterioridad a 1955. En verdad, su origen hay que rastrearlo durante el decenio peronista anterior.
} 
llegó a publicar dos números de la revista 4161. El primero fechado en octubre de 1963 y el segundo en junio de 1964. La publicación tenía notas dedicadas a la política y a la universidad $^{92}$. En las primeras, la JUP se presentaba a sí misma como una "generación joven" originada en la "lucha revolucionaria" que siguió a septiembre de 1955. Esta autoapreciación era común en grupos de JP que pretendían diferenciarse de una supuesta dirigencia "traidora" y "negociadora" que había claudicado frente al derrocamiento del peronismo ${ }^{93}$. Desde esta perspectiva general, la JUP se identificaba con el sector del sindicalismo combativo agrupado detrás de Andrés Framini, el dirigente textil que había sido electo gobernador de la provincia de Buenos Aires en las elecciones de 1962, las cuales finalmente fueron anuladas y precipitaron la destitución de Arturo Frondizi de la presidencia de la Nación. A través de la figura de Framini, 4161 exaltaba el programa de Huerta Grande de las 62 organizaciones como el único capaz de garantizar una “doctrina revolucionaria” en el peronismo ${ }^{94}$.

Las notas referidas a la universidad en 4161 seguían un razonamiento similar a las de carácter político. La JUP se presentaba como una nueva experiencia militante diferente a la antigua CGU, a la que consideraba una estructura caduca que no había hallado eco en las universidades de Buenos Aires y La Plata, y que incluso se había desgranado por "errores" y "abusos" de los "eternos aprovechadores que la pusieron al servicio de intereses mezquinos" 95 . A esta lectura sobre el pasado, la JUP sumaba una fuerte crítica al panorama político de la UBA de ese entonces. A su entender, luego de la disputa "laica o libre", los "humanistas católicos" y los "reformistas laicos" terminaron estableciendo una alianza que mantenía los pilares de la universidad instaurada con posterioridad a 1955. El traspaso del rectorado de Risieri Frondizi a Julio Olivera en 1962, no habría modificado en nada su actitud de "isla democrática" frente a la proscripción del peronismo y su incursión en políticas "limitacionistas" y "cientificistas" $"$. Frente a esta situación, la JUP consideraba que su tarea

\footnotetext{
${ }^{92}$ Hugo Chumbita tuvo un papel destacado en la elaboración de la revista. De acuerdo a su testimonio, fue el secretario de prensa de la JUP y el encargado de 4161. A su vez, en ANDE y/o JUP participaron Oscar Balestieri, Mario Kestelboim y Lelio Mármola. Entrevista a Hugo Chumbita, C.A.B.A., 05/01/2016; Entrevista a Oscar Balestieri, C.A.B.A., 02/12/2015; Entrevista a Mario Kestelboim, C.A.B.A., 12/11/2015; Entrevista a Lelio Mármola realizada por Aritz Recalde, C.A.B.A., 23/06/2006.

93 Bozza, A., "La resignificación revolucionaria del peronismo y sus protagonistas durante la etapa de proscripción", en Tortti, M. C. (dir.), La nueva izquierda argentina (1955-1976): socialismo, peronismo y revolución, Rosario, Prohistoria Ediciones, 2014, pp.75-76.

94 "Huerta Grande 10 objetivos revolucionarios", en 4161, № 1, octubre 1963. En ese tiempo, el sindicalismo combativo peronista produjo dos programas importantes: el de la Falda en 1957 y el de Huerta Grande en 1962. Ambos tenían tintes anticapitalistas y antiimperialistas. Entre sus medidas, figuraban la nacionalización de sectores claves de la economía y el control obrero de la producción.

95 "J.U.P. breve historia", en 4161, № 1, octubre 1963.

96 "Desarrollismo, humanismo y reforma en el gobierno universitario", en 4161, № 2, junio 1964. Con la idea de "isla democrática" hacían referencia a la existencia de elecciones libres en la universidad y no en el resto del país. Por "limitacionismo" entendían una política universitaria tendiente a recortar el presupuesto e impedir con
} 
era impulsar la "nacionalización mental" de los estudiantes para ligarlos a la "lucha concreta" de los trabajadores, mediante su presencia en el quehacer extrauniversitario y universitario. Aunque en este último punto, la práctica de la propia organización parecía dar a entender que por actividad política en la universidad no concebían más que denunciar, abstenerse o votar en blanco en las elecciones estudiantiles, organizar conferencias y trastocar la estabilidad de las casas de estudio con "tomas" y "actos relámpagos". Sugestivo de esto era que sólo participaron en una oportunidad en las elecciones de la Facultad Derecho y las dos ocupaciones que realizaron del rectorado de la calle Florida: una el 27 de mayo de 1964 en el marco del Plan de Lucha de la CGT y la otra el 16 de septiembre de ese mismo año, en repudio de un nuevo aniversario de la "Revolución Libertadora"97. Más que una militancia específica en el ámbito estudiantil, el norte de la JUP parecía ser el de captar universitarios para insertarlos en las actividades del sindicalismo y las organizaciones políticas del peronismo proscripto ${ }^{98}$.

Hacia mediados de los sesenta, la JUP corrió el mismo destino que la antigua CGU. Había hallado poco eco entre el alumnado y terminó desarticulándose. En respuesta a esta situación, los ANDE y lo que quedaba de la JUP formaron en 1966 la Federación de Agrupaciones Nacionales de Estudiantes Peronistas (FANDEP) ${ }^{99}$. Aunque el cambio de siglas y la creación de la nueva entidad tampoco trajeron una modificación sustancial en su peso e influencia en el ámbito porteño. De todas maneras, 1966 no fue un año más en la historia de la universidad argentina y, en cierta medida, trajo un antes y un después en muchos aspectos. Uno de estos cambios fue la aparición de nuevas agrupaciones estudiantiles que progresivamente se identificaron con el peronismo. En el contexto de la intervención de Onganía, ellas permitieron robustecer la presencia política de dicho movimiento en las casas de estudio y nutrirlo de un conjunto de militantes que provenían, en buena medida, de esos sectores humanistas y reformistas que la revista 4161 señalaba como los responsables de la indiferencia universitaria frente a la proscripción del peronismo. En los siguientes subapartados reconstruimos el itinerario de esas organizaciones, haciendo hincapié en la trayectoria de sus principales dirigentes. Más adelante, nos concentramos en sus

distintas trabas el ingreso de los sectores populares a las casas de estudio. Cuando hablaban de "cientificismo" hacían alusión a un tipo de desarrollo científico desligado del compromiso político y subordinado a los subsidios de organismos y fundaciones estadounidenses.

97 "Ocupación de las universidades por las Juventudes Universitarias Peronistas", en 4161, № 2, junio 1964. También pueden consultarse documentos sobre las "tomas" en: Baschetti, R., Ob. cit., 2016, p.133.

${ }^{98}$ En el segundo capítulo volveremos a tratar este tema y a analizar la forma de hacer política del peronismo en la universidad.

${ }_{99}$ Una reseña de los orígenes de FANDEP, puede consultarse en: "Herederos de la práctica popular", en Primera Plana, $\mathrm{N}^{\circ} 488,6$ de junio 1972. 
posicionamientos políticos durante la segunda mitad de los sesenta.

\section{El Frente Estudiantil NaCionaL}

A sólo un año del golpe de Onganía surgió el Frente Estudiantil Nacional (FEN), a raíz de una articulación entre agrupaciones de Buenos Aires, Rosario y Córdoba que luego se extendió rápidamente a Mendoza, Tucumán y Mar del Plata. Aunque la columna vertebral de la organización y su centro fundacional estaban vinculados a la Facultad de Filosofía y Letras de la UBA, especialmente a la joven carrera de Sociología ${ }^{100}$. De ese ámbito provenía Roberto Grabois, el principal referente e impulsor de la agrupación. "Pajarito" había empezado a militar tempranamente en las filas del Partido Socialista (PS). Luego de su ruptura en 1958, quedó vinculado al sector del PS Argentino (PSA) que se distanció de la política más antiperonista del ghioldismo, agrupado en el PS Democrático ${ }^{101}$. En 1961, Grabois participó activamente en la victoria electoral de Alfredo Palacios como senador por Capital Federal; proceso que contó con el respaldo del Partido Comunista (PC) y estuvo tenido de una fuerte tónica pro cubana ${ }^{102}$. A esto se sumaban los contactos previos de algunos militantes del PSA con sindicalistas del peronismo combativo, que incluso se remontaban a la toma del Frigorífico Lisandro de la Torre de $1959^{103}$. Luego del triunfo de Palacios, los comunistas y socialistas más entusiastas con la Revolución Cubana que participaban en la revista Che, hablaban de la necesidad de formar un frente de liberación nacional con la presencia de esas tres fuerzas políticas ${ }^{104}$. Si bien Grabois no formó parte de ese proyecto editorial y de las siguientes fracturas del socialismo que dieron origen al PS Argentino de Vanguardia (PSAV), experimentó todas estas discusiones ${ }^{105}$.

En 1963, luego de un breve paso por la Facultad de Derecho, Grabois recaló en la carrera de Sociología y desde ese ámbito se incorporó a la Lista de Izquierda Mayoritaria

\footnotetext{
${ }^{100}$ Reta, A., El proceso de peronización dentro del movimiento universitario en los años sesenta. El caso del FEN, Tesis de Maestría, FSOC, UBA, 2010; Grabois, R., Memorias de Roberto Pajarito Grabois: de Alfredo Palacios a Juan Perón (1955-1974), CABA, Corregidor, 2014, p.15.

${ }^{101}$ En el PSA convergieron la juventud socialista junto a dirigentes como Alfredo Palacios, Alicia Moreau de Justo y Carlos Sánchez Viamonte. Para un análisis de las distintas rupturas que sufrió el PS en los sesenta, véase: Tortti, M. C., El viejo partido socialista y los orígenes de la nueva izquierda, Bs. As., Prometeo, 2009.

${ }^{102}$ El ala izquierda del PSA, vinculada a dirigentes juveniles como Alexis Latendorf y David Tieffenberg, jugó un papel clave en el acuerdo con el PC y en la búsqueda de apoyo de sectores del peronismo combativo, entre los cuales estaban Jorque Di Pasquale y Sebastián Borro. Ibídem, pp.164-165.

${ }^{103}$ Grabois, R., Ob. cit., 2014, pp. 65 y 68.

${ }^{104}$ En 1961 la revista Che era un proyecto compartido entre la izquierda del PSA y el PC, aunque ello no fuera explicitado en sus páginas. Tortti, M. C., Che. Una revista de la nueva izquierda (1960-1961), Bs. As., CEDINCI, 2013.

${ }^{105}$ En este punto, es importante tener en cuenta que Tieffenberg, uno de los principales impulsores del PSAV, era primo hermano de la madre de Grabois, con lo cual ambos tuvieron contactos desde muy temprano. El PSAV profundizó la línea política que apuntaba a la formación de un frente de liberación nacional basado en la unidad de la izquierda y el peronismo combativo.
} 
(LIM) que lideraba Daniel Hopen, un estudiante avanzado enrolado en las filas de Palabra Obrera (PO); organización trotskista que en ese momento encabezaba Nahuel Moreno y predicaba el "entrismo" en el peronismo ${ }^{106}$. El LIM tenía contactos políticos con la Tendencia Antiimperialista Universitaria (TAU), una entidad estudiantil que se referenciaba con el Movimiento de Izquierda Revolucionaria Argentina (MIRA), otra organización trotskista cuyo referente en la UBA era el estudiante de Derecho Héctor Poggiese ${ }^{107}$. En marzo de 1964, el LIM y el TAU impulsaron un acto en Filosofía y Letras donde recordaron a los fusilados de José León Suárez y homenajearon a los abatidos en la fallida incursión del Ejército Guerrillero del Pueblo (EGP) en la salva salteña ${ }^{108}$. Junto a Jorge Masetti, habían perdido la vida cuatro estudiantes de esa facultad, entre los cuales estaba Marcos Slajter, uno de los primeros graduados de Sociología que militaba en el Movimiento de Liberación Nacional (MLN) de los hermanos Viñas ${ }^{109}$.

Un año después de estos sucesos, Grabois fue candidato a presidente del Centro de Estudiantes de Filosofía y Letras (CEFYL) por la lista del Frente Antiimperialista Universitario (FAU), el cual había surgido de la alianza entre el LIM y el TAU. La elección la terminó perdiendo frente a Acción Reformista de Filosofía y Letras (ARFYL), la lista del PC donde participaban Oscar Landi e Isidoro Cheresky ${ }^{110}$. Sin embargo, desde su participación en la FUBA y la FUA, el FAU formó parte de las nutridas movilizaciones que se realizaron en 1965 para exigir mayor presupuesto universitario y repudiar la invasión de EEUU a Santo Domingo, como en la recordada marcha del 12 mayo donde fue asesinado el militante comunista y estudiante de medicina Horacio Daniel Grinbank. En esa oportunidad, la CGT -

\footnotetext{
${ }^{106}$ Dentro del trotskismo argentino, PO se caracterizó por su fuerte ligazón con el peronismo y por su política "entrista", la cual consistía en insertarse en los movimientos de masas con el objetivo de "ganar" grupos y orientarlos hacia el partido revolucionario. Hopen estaba relacionado al sector de PO dirigido por Ángel Bengochea, quien a principios de los sesenta viajó a Cuba y entabló contactos políticos con el "Che" Guevara. Tarcus, H. (dir.), Diccionario biográfico de la izquierda argentina, Bs. As., Emecé, 2007, pp.306-307.

${ }^{107}$ El MIRA era encabezado por Ramón Horacio Torres Molina. Surgió en 1961 a raíz de una ruptura del MIR Praxis de Silvio Frondizi; alegando, entre otras cosas, la necesidad de una ideología revolucionaria y nacionalista que comprendiera mejor al peronismo. Cuando el MIRA se disolvió en 1965, varios de sus integrantes pasaron al peronismo y tuvieron influencia en la formación de la Federación Universitaria de la Revolución Nacional (FURN), una de las primeras agrupaciones universitarias que se definió como peronista. Bajo la influencia de John William Cooke, su primera conducción combinaba adhesión al peronismo y a la lucha armada. Ibídem, pp.225-227; Tortti, M.C., Ob. cit., 2009, p.368.

${ }_{108}$ Califa, J. S., Reforma y revolución. La radicalización política del movimiento estudiantil de la UBA 1943 1966, CABA, Eudeba, 2014, pp.256-257.

${ }^{109}$ Al EGP estuvieron vinculados grupos disidentes del PC como el de José Aricó, algunos activistas del PSAV y militantes de PO relacionados a Bengochea. Como dijimos, a esta sector pertenecía Hopen, el líder del LIM. Rot, G. Los orígenes perdidos de la guerrilla en la Argentina: la historia de Jorge Ricardo Masetti y el EGP, Bs. As., Waldhuter, 2010, p.197.

${ }^{110}$ Pueden consultarse documentos del FAU en Grabois, R., Ob. cit., 2014, p.143 y 147. ARFYL ya había ganado las elecciones estudiantiles en 1964, el mismo año de su creación. Buchbinder, P., Historia de la Facultad de Filosofía y Letras, Bs. As., Eudeba, 2010, p. 213.
} 
en pleno Plan de Lucha- convergió con la FUA en una movilización al Congreso repudiando la injerencia estadounidense y reclamando la no aprobación de la participación argentina en la incipiente Fuerza Interamericana de $\mathrm{Paz}^{111}$.

Luego del alejamiento de Hopen, Grabois se convirtió en el referente del FAU. Su presencia en los encuentros intercentros de la FUA en 1965, le permitieron a la agrupación establecer dos contactos políticos que serían importantes unos años después ${ }^{112}$. El primero era la Agrupación Reformista Universitaria (ARAU) de la Facultad de Ciencias Matemáticas de Rosario, donde tenían protagonismo Eduardo Ceballos y Hernán Pereyra, presidentes del centro de estudiantes en distintas oportunidades ${ }^{113}$. Mientras el segundo, eran los militantes reformistas de la Facultad de Medicina de Córdoba agrupados en torno a Rodolfo Vittar y Luis Daichman. El FAU, los rosarinos y los cordobeses fueron la columna vertebral de la fundación del FEN en 1967, cuando decididamente se propusieron vincularse al peronismo desde el movimiento estudiantil. Luego extendieron sus redes militantes a Mar del Plata, Mendoza y Tucumán. Además, en la UBA llegaron a incorporar a sus filas a Renovación Reformista (RR), agrupación que dirigía el centro de estudiantes de Ciencias Económicas bajo la presidencia de Carlos Peola ${ }^{114}$.

Más allá de estas ramificaciones, lo importante es resaltar que el establecimiento del FEN como una agrupación de "pasaje al peronismo" fue posible, en parte, porque sus principales núcleos provenían de una nueva izquierda estudiantil que en los años previos al golpe de Onganía había sido sacudida por la gesta cubana y había abandonado la vieja actitud antiperonista del reformismo. Sintomático de esta cuestión, fue el VII Congreso Nacional de Estudiantes de la FUA realizado en Buenos Aires entre el 8 y 12 de octubre de 1965. Sus resoluciones expresaban un apoyo explícito al Plan de Lucha de la CGT y al gobierno de Cuba. También acompañaban las clásicas banderas de autonomía, gobierno tripartito, participación estudiantil y libertad de cátedra con otras reivindicaciones. Entre ellas, sobresalían las críticas al "limitacionismo" por la escasez de presupuesto y las trabas al ingreso universitario, además de su impugnación a las políticas "cientificistas" que supuestamente ponían a las casas de estudio al servicio de los organismos internacionales. Todo esto en medio de una gran demanda política que llamaba a emprender la liberación

\footnotetext{
111 Califa, J. S., Ob. cit., 2014, p. 262.

${ }^{112}$ El FAU acudía a las reuniones de la FUA porque participaba en la secretaría de relaciones de la comisión directiva del CEFYL. Grabois, R., Ob. cit. 2014, p.172.

${ }^{113}$ La Facultad de Ciencia Matemática de Rosario abarcaba las carreras de Ingeniería, Arquitectura y Ciencias Exactas. Su centro estudiantil era el más importante y numeroso de Rosario. ARAU ganó su conducción en 1966 y 1968. Ibídem, p.158.

${ }^{114}$ Ibídem, p. 190.
} 
nacional y social en Argentina ${ }^{115}$.

\section{De la Unión Nacional de Estudiantes a la Corriente Estudiantil Nacional y Popular}

El FEN no fue la única agrupación que cambió la perspectiva del peronismo en la UBA tras la intervención de Onganía. El 10 de agosto de 1968 se constituyó en la ciudad de Rosario la Unión Nacional de Estudiantes (UNE). La nueva entidad surgió por la confluencia entre la Liga Humanista de Buenos Aires (LHBA), la Unión de Estudiantes del Litoral (UEL) y las filiales del Integralismo radicadas en Córdoba, Santa Fe, San Luis y el Nordeste. Los principales referentes de UNE fueron el humanista porteño Julio Bárbaro y el integralista cordobés Carlos Azócar ${ }^{116}$. El primero era un estudiante de Agronomía de la UBA y de Ciencias Políticas de la Universidad del Salvador que en 1963 se había convertido en secretario general de la LHBA y en 1966 en su presidente. En esa primera mitad de los sesenta, los humanistas habían obtenido la conducción del centro de estudiantes de Ciencias Económicas -en aquel momento la facultad más grande de América Latina- y dos personalidades de su tendencia política, Julio Olivera e Hilario Fernández Long, llegaron a ser rectores de la $\mathrm{UBA}^{117}$. En esos años, los humanistas también participaron en las demandas por mayor presupuesto universitario junto a reformistas e incluso fueron uno de los convocantes a la gran movilización del 12 de mayo de 1965, donde convergieron la FUA y la CGT bajo la consigna "Ningún soldado argentino en Santo Domingo"118. Si bien no cesaron las diferencias entre humanistas y reformistas, estos contactos tendieron a diluir el fuerte enfrentamiento que habían tenido unos años atrás frente a la instauración de universidades privadas. Medida que había terminado de hacer realidad el ex presidente Arturo Frondizi con la ley 14.557, la cual reglamentó el artículo 28 del decreto 6.403 de la dictadura del general Aramburu.

Como en el caso del FEN, el surgimiento de la UNE y su acercamiento al peronismo no pueden comprenderse sin tener como referencia las transformaciones suscitadas en el ambiente político-universitario porteño con anterioridad a 1966. En 1958, asumió el papado

\footnotetext{
${ }^{115}$ Ceballos, C. A., Los estudiantes universitarios y la política (1955-1970), Bs. As., Centro Editor de América Latina, 1985, pp. 81 y 107.

${ }^{116}$ Para una cobertura sobre la constitución de UNE, puede consultarse: "La semana estudiantil", en Semanario $C G T, \mathrm{~N}^{\circ} 17,22$ de agosto 1968.

${ }^{117}$ Entrevista a Julio Bárbaro, C.A.B.A., 21/01/2016; Bárbaro, J., Juicio a los '70, Bs. As., Sudamericana, 2009, pp.40-41. En 1965, los humanistas perdieron la conducción del centro de estudiantes que habían obtenido tres años antes frente a RR, la agrupación reformista encabezada por Peola que luego del golpe se integró al FEN de Grabois.

${ }^{118}$ El reclamo por mayor presupuesto universitario fue una demanda histórica del movimiento estudiantil, pero se agudizó en la primera mitad de los sesenta. Desde 1963, esto llevó a una unidad entre reformistas y humanistas en torno al reclamo. Califa, J. S., Ob. cit., 2014, pp. 246 y 262.
} 
Ángelo Giuseppe Roncalli, quien eligió el nombre de Juan XXIII para encabezar la curia romana luego de la muerte de Pío XII. Si bien el nuevo Papa fustigó la experiencia cubana, su sorpresiva convocatoria e impulso al Concilio Vaticano II produjo resonancias importantes en el mundo católico argentino. Las nuevas encíclicas y debates llevaron a una revalorización de la doctrina social de la Iglesia y a una apertura hacia la "modernidad", la cual implicó un diálogo del catolicismo con otras ideologías y una crítica a las desigualdades producidas en el sistema capitalista ${ }^{119}$.

Todo este proceso se tradujo de diferentes maneras en distintos lugares del mundo y América Latina. En el tema particular que nos ocupa, son destacables dos experiencias. La primera es la "Línea de Apertura" que encabezó Horacio Sueldo en la Democracia Cristiana (DC), al intentar conformar una plataforma electoral con Raúl Matera -dirigente de la rama política del movimiento peronista- en las elecciones presidenciales de 1963. A pesar de que la coalición no pudo concretarse por la proscripción de Matera, el intento mostraba un alejamiento de las posiciones más antiperonistas que habían caracterizado a la DC desde su origen en 1954, en medio del conflicto entre la Iglesia Católica y el último gobierno de Perón ${ }^{120}$. Los humanistas como Bárbaro, si bien no eran necesariamente militantes orgánicos de la DC ni tampoco integraban una organización oficial como la Acción Católica Argentina, no fueron ajenos a los debates que generó la "Línea de Apertura" de Sueldo ${ }^{121}$.

La segunda experiencia destacable en el marco del Concilio Vaticano II fue que el "diálogo" entre cristianos y marxistas iniciado en Europa tuvo manifestaciones propias en la $\mathrm{UBA}^{122}$. Un caso relevante fue el extenso debate que entablaron León Rozitchner y Conrado Eggers Lan a principios de los sesenta. El primero era doctor en filosofía, había integrado la revista Contorno y militaba en el MLN. Mientras el segundo era un reconocido profesor de la Facultad de Filosofía y Letras que en su juventud había sido miembro de Acción Católica y luego se enroló en la DC, en donde realizó una militancia antiperonista que lo llevó a estar unos días detenido antes del golpe de $1955^{123}$. El debate con Rozitchner fue producto del reportaje que brindó Eggers Lan para el segundo número del Correo de C.E.F.Y.L en octubre

\footnotetext{
119 Deschner, K., La político de los Papas en el siglo XX, Zaragoza, Editorial Yalde, 2004; Morello, G., Cristianismo y Revolución. Los orígenes intelectuales de la guerrilla argentina, Córdoba, UCC, 2003; Verbitsky, H., La violencia evangélica. De Lonardi al Cordobazo (1955-1969), Bs. As., Sudamericana, 2008.

${ }^{120}$ Castro, F. y Salas, E., Norberto Habegger. Cristiano, descamisado, montonero, Bs. As., Colihue, 2011, pp. 14 y 17.

${ }^{121}$ Entrevista a Julio Bárbaro, C.A.B.A., 21/01/2016.

122 Según José Pablo Martín el diálogo entre católicos y marxistas comienza en la Argentina en 1962. Martín, J.P., El Movimiento de Sacerdotes para el Tercer Mundo. Un debate argentino, Los polvorines, UNGS, 2010, pp.182-183.

${ }^{123}$ Eggers Brass, T., "Conrado Eggers Lan, entre la filosofía antigua y el pensamiento nacional", en Revista de Historia Bonaerense, $\mathrm{N}^{\circ} 39$, mayo 2012, p.38.
} 
de 1962. En esa entrega, los propios estudiantes reformistas consideraban sus reflexiones como valiosos aportes para pensar la realidad. La tesis principal de Eggers Lan sostenía que el enfrentamiento entre marxistas y cristianos era "artificioso". A su entender, estos últimos también bregaban por acabar con la "enajenación" y alcanzar la realización plena de la persona humana, al liberarla del principal factor que la oprimía según los Evangelios: "la riqueza". En este punto, llegaba a afirmar que el marxismo no era más que una "secularización” de los motivos "más profundos" del pensamiento judeo-cristiano ${ }^{124}$.

Luego de esta entrevista, comenzó la polémica y se extendió hasta 1964 en el segundo, tercer y cuarto número de la revista Pasado y Presente, que en ese entonces impulsaban jóvenes intelectuales disidentes del PC, como José Arico y Juan Carlos Portantiero. El debate se tituló "Marxismo o cristianismo" por el tono que finalmente adquirió. De acuerdo a la respuesta de Rozitchner, Eggers Lan caía en un "confusionismo moralizante" y el cristianismo era una comunidad que mantenía el dominio entre los hombres ${ }^{125}$. A su vez, aquél replicaba en duros términos al calificar a Rozitchner como un "marxista de derecha", que no comprendía la "madurez ideológica" colectiva en la que participaban los cristianos. Eggers Lan sostenía que este cambio lo había llevado a estrechar lazos con marxistas y a darse cuenta que su "teorización" y militancia contra el gobierno depuesto en 1955 habían sido un error ${ }^{126}$. Si bien el intercambio no se dio en buenos términos, sirvió para impulsar otras actividades similares, como la realizada en el aula magna de Filosofía y Letras en octubre de 1965, cuando el asesor de Acción Católica en la Facultad de Ciencias Económicas, Carlos Mugica, compartió una mesa de debate junto a Guillermo Tedeschi y los marxistas Juan Rosales y Fernando Nadra.

Con estos antecedentes, luego del golpe de 1966 Bárbaro impulsó los Grupos Marcha en el local de la Fundación Argentina para la Promoción del Desarrollo Económico y Social (FAPES), que le facilitaron contactos suyos de la DC. En su organización, también participaron ex dirigentes de la juventud demócrata cristiana como Norberto Habegger, Oscar De Gregorio y Horacio Mendizábal. Los Grupos Marcha tenían el objetivo de formar universitarios y debatir los cruces entre política y religión. En sus encuentros, participaban invitados con distintas trayectorias: el propio Eggers Lan, el socialista Gregorio Selser, el sindicalista peronista Amado Olmos, el padre Miguel Mascialino y hasta políticos del Partido Socialista de la Izquierda Nacional (PSIN), como Jorge Abelardo Ramos y Jorge Enea

\footnotetext{
124 “Cristianismo y marxismo", en Correo de CEFYL, № 2, Octubre 1962, pp.1-2.

125 Rozitchner, L, "Marxismo o cristianismo" en Pasado y Presente, № 2-3, julio-diciembre 1963, pp.113-133.

126 Eggers Lan, C., "Acerca de 'marxismo o cristianismo'. Respuesta a la derecha marxista", en Pasado y Presente, № 4, Año 1, enero - marzo 1964, pp.376-382.
} 
Spilimbergo ${ }^{127}$.

El contacto con otras vertientes políticas que fomentaban los Grupos Marcha, también tuvo lugar en la UNE. Al poco tiempo de su creación, se adhirió a sus filas la Corriente Estudiantil Nacional y Popular (CENAP). La misma surgió de un desprendimiento del FEN promovido por Poggiese ${ }^{128}$. Él había militado en la Unión de Estudiantes Secundarios (UES) de Punta Alto, aunque en sus primeros años como estudiante de Derecho de la UBA recaló en el Movimiento Universitario Reformista (MUR). A principios de los sesenta, se vinculó al MIRA y formó junto a otros alumnos la Corriente Estudiantil Antiimperialista (CEA). Como indicamos anteriormente, en esos años los militantes vinculados al MIRA también tenían presencia en la Facultad de Filosofía y Letras a través del TAU, la agrupación que formó el FAU junto al LIM. Esta unión fue el antecedente directo del FEN. Sin embargo, al momento de su constitución, el CEA y algunos militantes del TAU decidieron no encolumnarse detrás de Grabois y optaron por formar la CENAP, a la que también se sumó, gracias a las distintas alianzas políticas que había establecido Poggiese, la Tendencia Universitaria Popular de Arquitectura y Urbanismo (TUPAU) ${ }^{129}$. Finalmente, al adherirse la CENAP a la UNE, ésta ensanchó sus bases militantes más allá de la vertiente socialcristiana, al sumar sectores reformistas que en su mayoría pertenecían a una izquierda que no respondía al PC.

\section{LAS JUVEnTUdes ARgentinas PARA la EMANCIPACión NACIONAL}

Las Juventudes Argentinas para la Emancipación Nacional (JAEN) fue otra de las agrupaciones que modificó la situación del peronismo en la UBA luego del golpe de Onganía. El JAEN se fundó en el bar "La Perla" del barrio de Once en marzo de $1967^{130}$. A diferencia del FEN, UNE y CENAP, desde sus inicios no se concibió como una agrupación estudiantil, sino como una estructura política juvenil más amplia que pretendía intervenir en distintos frentes, entre ellos el universitario. Su principal referente fue Rodolfo Galimberti, en ese entonces estudiante de la Facultad de Derecho. Aunque el primer contacto del líder de JAEN con el peronismo no se originó en dicha organización. Galimberti procedía de una familia nacionalista y católica pro peronista. A principios de los sesenta, había comenzado a militar

\footnotetext{
${ }^{127}$ Bárbaro, J., Ob. cit., 2009, p.59.

128 Entrevista a Héctor Poggiese, C.A.B.A., 12/01/2016; "Nos divertíamos como locos. Entrevista a Héctor Poggiese", en Política, cultura y sociedad en los '70, $\mathrm{N}^{\circ} 2$, julio 1997, p.23. El surgimiento de CENAP también es reseñado en: "Herederos de la práctica popular", en Primera Plana, N 488, 6 de junio 1972.

${ }^{129}$ Entrevista a Roberto Corvaglia, C.A.B.A., 11/09/2015. Más adelante hablaremos de este militante de TUPAC que integró CENAP. También véase: Corvaglia, R., "La militancia al servicio de la causa nacional y popular en los claustros universitarios", en Baschetti, R., Ob. cit. 2016, pp.186-190.

${ }^{130}$ Entrevista a Ernesto Jauretche, La Plata, 15/01/2016; Larraquy, M. y Caballero, R., Galimberti. De Perón a Susana de Montoneros a la CIA, Bs. As., Aguilar/Altea/ Taurus/Alfaguara, 2011, p.63.
} 
en el Movimiento Nacionalista Tacuara (MNT), una agrupación con tintes fascistas y anticomunistas que era conducida por Alberto Ezcurra Uriburu ${ }^{131}$. En aquel momento, algunos integrantes del MNT ya habían abandonado las posturas más elitistas y se habían acercado al sindicalismo combativo peronista, como en la toma del frigorífico Lisandro de la Torre de 1959. Esta aproximación llevó a la ruptura de la agrupación de Ezcurra y al surgimiento del Movimiento Nacionalista Revolucionario Tacuara (MNRT) a fines de 1962. Al año siguiente, este grupo terminó de hacerse conocido con el asalto armado al transporte de caudales del Policlínico Bancario. Luego de la operación, el propio MNRT se definió en la revista 4161 de la JUP como una organización que reconocía el liderazgo de Perón y pretendía imponer con la lucha armada y la movilización popular el programa de Huerta Grande $^{132}$. Galimberti no integró directamente esta facción que encabezaron Joe Baxter y José Luis Nell, pero no fue ajeno al debate generado en el nacionalismo argentino cuando el MNRT trazó una línea de acercamiento al marxismo y al peronismo de izquierda ${ }^{133}$. En 1964, Galimberti participó en la procesión hasta Luján para rezar por la frustrada vuelta de Perón, impulsada por el Comando de Organización $(\mathrm{CdeO})$ de Brito Lima ${ }^{134}$. Al año siguiente, una vez anotado en la facultad, se convirtió en un seguidor "periférico" del Sindicato Universitario de Derecho (SUD) que lideraba Antonio Valiño y participaban varios militantes de Tacuara ${ }^{135}$.

Desde esta trayectoria previa, Galimberti se hizo cargo de la jefatura de JAEN. No obstante, también integraron la agrupación otros militantes importantes que contribuyeron a delimitar su perfil político. Entre ellos, había dos profesores de la Universidad del Salvador. Uno era Augusto Pérez Lindo, quien dictaba clases en la materia Introducción a las Ciencias Políticas y había dado sus primeros pasos en la Unión Nacionalista de Estudiantes Secundarios, el antecedente directo de la formación del MNT en 1957. El propio Pérez Lindo había sido quien acercó a Galimberti a la filas capitaneadas por Ezcurra. El otro docente era Carlos Grosso, un ex seminarista jesuita y licenciado en letras ${ }^{136}$. Él escribió uno de los

\footnotetext{
${ }^{131}$ Ibídem, pp. 45-46.

132 "MNRT: violencia revolucionaria", en 4161, N2, Junio 1964.

133 Bozza, A., Ob. cit., 2014, p. 68.

134 Brito Lima había sido afiliado de la UES y el CdeO hundía sus raíces en grupos de activistas de la JP. Cuando los dispersos núcleos juveniles de la Resistencia se agruparon en una Mesa Ejecutiva en 1959, las secretarías pasaron a funcionar como una suerte de reparto de poder interno. Brito Lima se erigió en líder de un grupo dirigido conjuntamente con Rubén Macchiavello, Pablo Flores y Domingo Paleo. En un congreso realizado en el Sindicato del Calzado en 1961, este sector perdió una ajustada votación interna para la dirección de la JP. Fue entonces cuando Brito Lima se escindió del resto de la Mesa Ejecutiva con la Secretaría de Organización, de la cual devino el nombre de su agrupación. Denaday, J. P. "Comando de Organización: un peronismo plebeyo, combativo y nacionalista (1961-1976)”, en Quinto sol, Santa Rosa, No 1, abril 2016, pp. 1-21.

${ }^{135}$ Larraquy, M. y Caballero, R., Ob. cit., 2011 , p. 61.

${ }^{136}$ Ibídem, pp. 45-46.
} 
primeros documentos importantes de JAEN que sería publicado en 1969 por la editorial Sudestada, titulado "El movimiento nacional y la Iglesia"137. En sus páginas, JAEN se reconocía como parte de un sector católico "esclarecido" que bregaba por la "liberación" de América Latina. Postura que acompañaban con una fuerte crítica a la institución eclesiástica por haber enfrentado al peronismo en los años cincuenta y provocado una ruptura que, a su entender, aún no se había vuelto a recomponer ${ }^{138}$.

Otro militante importante de JAEN fue Ernesto Jauretche, el sobrino de un reconocido ensayista que había sido dirigente de la Fuerza de Orientación Radical de la Joven Argentina (FORJA) y presidente del Banco de la Provincia de Buenos Aires durante el primer gobierno de Perón. El joven Jauretche, egresado de la Escuela Técnica Otto Krause, desde un primer momento estuvo vinculado al peronismo por su participación en la UES, por la trayectoria política de su tío Arturo e incluso de sus propios padres. Ya en los tiempos de JAEN, Jauretche estaba inscripto en la carrera de Historia de Filosofía y Letras y trabajaba como periodista en El Economista, donde conoció a quien fue el principal financista de las actividades de JAEN, Diego Muniz Barreto. Heredero de una gran fortuna familiar y otrora activo militante antiperonista, Muniz Barreto trabajaba en ese entonces junto al secretario Legal y Técnico de Onganía, Roberto Roth. Conoció a Jauretche cuando le brindó información para revelar que el ministro de Economía, Adalbert Krieger Vasena, formaba parte del directorio de la empresa Swift-Deltec. Más allá del hecho particular, este caso era sintomático de la política de JAEN, la cual intentaba tender puentes con distintos sectores, involucrados tanto con la Iglesia Católica, como en ámbitos políticos y militares ${ }^{139}$.

El último integrante relevante de JAEN que no podemos pasar por alto era Jorge Raventos. A diferencia del resto, había ingresado al PSIN de Ramos a principios de los sesenta, al poco tiempo de su fundación ${ }^{140}$. Era uno de los responsables del "núcleo" partidario de Filosofía y Letras, el cual también integraban el ex militante socialista Ernesto Laclau y la hija de un reconocido intelectual expulsado del PC por adherir al gobierno de Perón en los años cuarenta: Adriana Puiggrós ${ }^{141}$. Desde sus inicios, la línea política del PSIN buscaba formar una estructura partidaria independiente que sea capaz de orientar al peronismo hacia el socialismo. Por eso, no era extraño que propiciara en sus frentes el acercamiento a las

\footnotetext{
${ }^{137}$ Sudestada era una editorial que pertenecía a Eduardo Luis Duhalde y Rodolfo Ortega Peña. Más adelante abordaremos el vínculo entre ellos y Galimberti.

${ }^{138}$ JAEN, "El movimiento Nacional y la Iglesia", en Cuadernos del Movimiento Nacionalista Pampero, Bs.As., Sudestada, 1969, pp. 15-16.

139 Entrevista a Ernesto Jauretche, La Plata, 15/01/2016. También véase: Salas, E., De resistencia y lucha armada, CABA, Punto de Encuentro, 2014, p. 56.

${ }^{140}$ El PSIN se fundó en 1962. Tarcus, H., Ob. cit. 2007, p. 549.

${ }^{141}$ Entrevista a Adriana Puiggrós, C.A.B.A., 09/02/2016.
} 
manifestaciones del sindicalismo peronista, tal como hizo el 22 de mayo de 1964 cuando impulsó desde el CEFYL la toma del rectorado de la UBA en apoyo al Plan de lucha de la CGT. A mediados de los sesenta, Raventos se alejó del PSIN, formó por un breve tiempo el Partido Revolucionario de la Izquierda Nacional (PRIN) y luego la revista Patria Grande, hasta que finalmente se incorporó al $\mathrm{JAEN}^{142}$. Como se observa en este último caso, y en otros descriptos anteriormente, las fronteras ideológicas de las nuevas organizaciones eran porosas y permitían el ingreso de militantes de distintas trayectorias, al dejar atrás antagonismos que hasta hacía poco parecían irreconciliables, como reformistas versus católicos y peronistas versus antiperonistas.

El intento de formar una agrupación juvenil amplia que sea capaz de influir en diversos espacios, condujo a JAEN a crear sus propios frentes universitarios. Aunque éstos, al igual que el conjunto de la organización, fueron pequeños y sólo nuclearon un puñado de militantes. En 1967, Galimberti junto a Héctor Mauriño, Ricardo Mitre y Luis Alberto Vuistaz armaron el Frente 17 de Octubre en la Facultad de Derecho. El primero había cursado el secundario con Galimberti en el Instituto Domingo Faustino Sarmiento y los otros dos llegaron al JAEN de la mano de Luis Alberto Spinetta y Emilio Del Guercio, dos militantes periféricos de la agrupación que estaban inscriptos en la Escuela de Bellas Artes. Ambos habían sido compañeros de Mitre y Vuistaz en el Instituto San Román. Dos años después, el propio Galimberti decidió reforzar la incursión de JAEN en la universidad e impulsó la formación del Comando General Juan José Valle en Filosofía y Letras, donde terminó recalando un estudiante de Historia apodado "Chacho": Carlos Álvarez ${ }^{143}$. De esta manera, la aparición de JAEN seguía sumando siglas a un escenario político-universitario donde parecía adquirir mayor peso el término "nacional" y acrecentarse el número de agrupaciones que se mostraban afines al peronismo.

\section{III - ESTUdIANTES PERONISTAS DE LA CGT DE LOS ARGENTINOS}

Hasta el momento analizamos cómo cambió el panorama del peronismo en la UBA tras el golpe de Onganía, a raíz de la aparición de un conjunto de agrupaciones estudiantiles, cuyos principales referentes procedían de espacios católicos, nacionalistas o reformistas. Pero todavía falta abordar una cuestión importante que permite entender aún más esta experiencia ¿cómo interpretaban al peronismo los estudiantes que apenas habían vivido su temprana

\footnotetext{
${ }^{142}$ Regali, E. A., Abelardo Ramos. La izquierda nacional y la nación latinoamericana, Córdoba, Ferreyra Editor/Ediciones del Corredor Austral/CICUSS, 2012, pp. 318-319.

${ }^{143}$ Larraquy, M. y Caballero, R., Ob. cit. 2011, pp. 65-66 y p.79.
} 
infancia en las primeras presidencias de Perón y en su mayoría provenían de círculos sociales que habían respaldado su derrocamiento en 1955? Para responder a este interrogante, no basta con señalar que varios integraban ámbitos militantes que abandonaron sus posturas antiperonistas con anterioridad a 1966. También es necesario abordar los posicionamientos políticos concretos que tomaron en el marco de la dictadura de Onganía. Especialmente, cuando apareció la CGT de los Argentinos (CGTA) y se articuló un ámbito de oposición frontal al régimen militar que incluía una parte importante del activismo estudiantil.

Este proceso no fue lineal dado que tardó en generarse una convocatoria amplia contra el gobierno militar. Como apuntamos, la asonada del 28 de junio de 1966 contó con un respaldo social, político y mediático importante. En este contexto, la UBA fue la única institución pública en poner reparos contra el golpe. Mediante una declaración, el rector humanista Fernández Long junto a la mayoría del Consejo Superior calificó al 28 de junio como un "día aciago" y llamó a la defensa de la autonomía universitaria ${ }^{144}$. Tan sólo un mes después, el gobierno finalmente decretó la intervención de todas las casas de estudio y desalojó violentamente la toma de algunas facultades porteñas que intentaban frenar la medida. Luego de "La noche de los bastones largos", el pico más alto de protestas se vivió en Córdoba en la movilización nacional convocada por la FUA el 7 de septiembre de 1966; pero la respuesta fue la misma y esta vez el accionar policial produjo la muerte del militante estudiantil radical Santiago Pampillón. Desde el mes de octubre, la oposición comenzó su declive y en abril del año siguiente Onganía finalmente puso en vigencia una nueva normativa universitaria que prohibía cualquier tipo de actividad política en las aulas.

En el plano nacional, recién en 1968 comenzaron a revitalizarse las protestas contra el régimen militar. Un punto clave fue la realización del congreso normalizador "Amado Olmos" de la CGT celebrado el 28 de marzo. En el mismo obtuvieron mayoría los sindicatos que propugnaban una oposición abierta a Onganía y designaron como secretario general a Raimundo Ongaro, dirigente de la Federación Gráfica Bonaerense. El vandorismo en minoría impugnó la decisión, quedando conformadas de hecho dos CGT: Azopardo y de los Argentinos $^{145}$. La relevancia de la CGTA radicó en la propuesta de crear un polo opositor

\footnotetext{
144 "Declaración de la Universidad de Buenos Aires", 28 de junio 1966. Se puede consultar el documento en: Baschetti, R., Ob, cit., 2016, p. 144.

${ }^{145}$ La CGT se encontraba intervenida a partir del fracaso del plan de lucha de 1967, por lo que se convocó a un congreso en marzo de 1968 con el fin de normalizarla. El objetivo del encuentro era conformar un nuevo secretariado, elegido por mayoría y de forma representativa. En los tiempos previos, había comenzado a consolidarse una fuerte corriente interna o "línea dura", conformada por un grupo de activistas y dirigentes sindicales que bajo la bandera de "recuperar la CGT para la defensa de los intereses de los trabajadores" recorrieron el interior del país y fueron acumulando fuerzas. Esta rama era encabezada en ese momento por Amado Olmos, pero también adherían a ella Ongaro, Julio Guillán y Jorge Di Pascuale. Los cuatro eran
} 
amplio a la dictadura con tintes anticapitalistas y antiimperialistas. Este proyecto lo manifestó desde un inicio en el programa " $1^{\circ}$ de mayo: mensaje a los trabajadores y al pueblo argentino" que publicó el número inaugural del Semanario $C G T$, su órgano de difusión oficial a cargo del mismo Ongaro y el secretario de prensa de la central, Ricardo De Luca, bajo la dirección periodística de Rodolfo Walsh ${ }^{146}$. El plan de la CGTA retomaba implícitamente los programas de La Falda (1957) y Huerta Grande (1963) del sindicalismo combativo peronista, ya que proponía una nacionalización de los sectores clave de la economía y una erradicación de las estructuras capitalistas de las que no podía surgir "ni una sociedad justa ni cristiana". A su entender, lo que había que realizar era un "sindicalismo integral" que anhele la "liberación nacional" y el "control del poder", no uno atento solamente a cuestiones gremiales como los “convenios" y las “colonias de vacaciones". Desde esta posición, la central de Ongaro convocaba a "empresarios nacionales, pequeños comerciantes, universitarios, artistas y religiosos" a sumarse a ese programa y a crear un frente contestatario a la dictadura de Onganía ${ }^{147}$

Si bien la CGTA estuvo lejos de llevar adelante este ambicioso proyecto, estableció una verdadera articulación con otros actores políticos y sociales, especialmente, con el movimiento estudiantil. No por nada, sus adversarios la trataban socarronamente como "la CGT de los estudiantes" y llegó a establecer en sus propias filas una comisión "obreroestudiantil" ${ }^{\prime 148}$. Este vínculo en buena medida fue posible por los contactos que empezaron a tejerse en las protestas de 1968, como las desatadas el 28 de junio cuando la CGTA convocó a un acto en Plaza Once y en otros lugares del interior del país, para repudiar a la dictadura en su segundo aniversario. En la misma participaron la FUA y el FEN, el cual tuvo entre los heridos por la represión policial a sus dos principales dirigentes porteños: Grabois y Peola ${ }^{149}$. También, en el mes de septiembre, al cumplirse dos años del asesinato de Pampillón,

representantes del sindicalismo combativo peronista que criticaba duramente la política de negociación de Vandor con el régimen militar. Sotelo, L., "El mundo sindical entre la acción gremial y la acción política. Continuidades y rupturas de la CGT de los Argentinos respecto de las experiencias anteriores", en Tortti, M. C. (coord.), El lugar de la nueva izquierda en la historia reciente, PolHis - Boletín Bibliográfico Electrónico del Programa de Historia Política, No 10, segundo semestre de 2012, p. 163.

${ }^{146}$ Entre mayo de 1968 y febrero de 1970 fueron publicados 55 números del Semanario CGT. Bajo la dirección periodística de Walsh, había un equipo de redacción conformado por periodistas como Horacio Verbitsky y Rogelio García Lupo.

147 " $1^{\circ}$ de mayo: mensaje a los trabajadores y al pueblo argentino", en Semanario CGT, № 1,1 de mayo 1968.

${ }^{148}$ Según la revista Siete Días Ilustrados, una "cáustica humorada" de los "mandarines vandoristas" de la CGT Azopardo era la pregunta: "¿CGT de los argentinos o CGT de los estudiantes?". "La CGT de los estudiantes", en Siete Días Ilustrados, julio 1968. Reproducido en http://www.magicasruinas.com.ar/revdesto069.htm.

149 “Azopardo medita, el pueblo lucha”, en Semanario CGT, N 10, 4 de julio 1968. 
confluyeron en distintas protestas la FUA, FEN, UNE y FANDEP con la CGTA ${ }^{150}$. Como corolario de estos encuentros, el Semanario CGT publicó a fin de año una serie de entrevistas para ofrecer un panorama de la universidad y de las organizaciones estudiantiles con las que entablaba acciones. Los reporteados fueron Bárbaro por la UNE, Grabois por el FEN y Jorge Rocha por la FUA ${ }^{151}$. Este último era un estudiante de Derecho de la UBA que integraba el Comité Nacional de Recuperación Revolucionaria del Partido Comunista de la Argentina (CNRR), una escisión que había sufrido la Federación Juvenil Comunista (FJC) el 6 de enero de 1968, la cual al poco tiempo pasaría a llamarse Partido Comunista Revolucionario (PCR) y sus filas estudiantiles Frente de Agrupaciones Universitarias de Izquierda (FAUDI) ${ }^{152}$.

A pesar de la diversidad de sus trayectorias y anclajes ideológicos, en estas entrevistas los tres estudiantes compartían con la CGTA la actitud de enmarcar sus demandas particulares en un proyecto político que situaba su horizonte en la idea de liberación. Cada uno lo explicaba a su manera. Rocha sostenía que la movilización por el 50 aniversario de la Reforma del ' 18 realizada el 14 de junio de 1968 y el paro de la CGTA convocado diez días después, demostraban la creciente actividad de los estudiantes y los obreros contra la dictadura. Pero agregaba que todavía faltaba "integrar" y "superar" los postulados reformistas para ubicar la problemática estudiantil en un marco de "liberación nacional e internacional", tal como lo habían hecho "precursores" como Julio Antonio Mella y José Carlos Mariátegui $^{153}$.

Grabois y Bárbaro, por su parte, sostenían que la intervención de Onganía había acabado con la política reformista de la "isla universitaria", que sólo llevaba a prestarle atención a las demandas gremiales del estudiantado sin tener en cuenta el contexto político más amplio. De todas maneras, lo más interesante no eran estas ideas que incluso podían encontrarse con anterioridad a 1966, sino que la CGTA les ofreció una opción tangible de lo que entendían por peronismo y "conciencia nacional". Esto quedaba claro cuando Grabois sostenía que el movimiento estudiantil estaba eludiendo el error de 1930, 1945 y 1955, al comprender que el eje no era "reforma o anti-reforma", sino "imperialismo o peronismo revolucionario", al que definía como la "vanguardia de la clase obrera". A su entender, asumir

\footnotetext{
${ }^{150}$ El 10 de agosto se habían juntado todos estos sectores estudiantiles en la ciudad de Rosario para coordinar una semana de protesta del 6 al 12 de septiembre en articulación con la CGTA. "La semana estudiantil", en Semanario $C G T, \mathrm{~N}^{\circ} 17,22$ de agosto 1968.

151 "Hablan los estudiantes", Semanario CGT, № 33, 12 de diciembre 1968; "Los estudiantes son una columna de la liberación", en Semanario CGT, N 34, 19 de diciembre 1968.

${ }^{152}$ Esta ruptura del PC pasó a llamarse PCR desde el 10 de marzo de 1969. Fue la mayor escisión de la FJC en los sesenta y llevó a que los comunistas pierdan la conducción de la FUA en manos de sus propios ex compañeros de ruta. Gilbert, I., La Fede. Alistándose para la revolución. La Federación Juvenil Comunista 1921-2005, Bs. As., Sudamericana, 2009, pp. 520 y 528.

153 “Los estudiantes son una columna de la liberación”, en Semanario CGT, № 34, 19 de diciembre 1968.
} 
una "postura nacional" significaba hacer realidad el programa de la CGTA e integrar a los estudiantes a un frente hegemonizado por los sectores combativos del sindicalismo peronista, para acabar con la situación neocolonial de la Argentina y emprender el camino al socialismo $^{154}$.

Por consiguiente, no era cualquier peronismo el que tenían en mente dirigentes como Bárbaro o Grabois. Su idea de ser peronistas radicaba en sentirse parte de un movimiento de liberación tercermundista y socialista. Varios analistas han sostenido que desde los sesenta la Revolución Cubana jugó un papel clave en estas interpretaciones, al convertirse en un ejemplo concreto y latinoamericano de que al socialismo no lo hacían los partidos tradicionales de izquierda, sino los movimientos nacionales ${ }^{155}$. El propio Grabois abonaba esta idea en otra entrevista de 1968 que brindó junto a Bárbaro y Peola para La Hora de los Hornos, una película del Grupo Cine Liberación ${ }^{156}$. En ella, el dirigente del FEN decía que el mayor legado de la gesta cubana para los "marxistas-leninistas" como él, fue hacerlos comprender que el peronismo era el camino nacional al socialismo ${ }^{157}$.

Más allá de la Revolución Cubana, es relevante destacar que la CGTA jugó en sí misma un papel clave para los estudiantes que emprendieron en esos años el pasaje al peronismo. La central de Ongaro les ofreció una opción concreta desde el mundo obrero, en donde podían confluir peronistas, marxistas y cristianos. Esto era justamente lo que resaltaba Bárbaro en el mismo film de Fernando Solanas y Octavio Getino que circuló de manera clandestina, pero ampliamente entre la militancia de aquel entonces ${ }^{158}$. No era casual que subrayara este punto, debido a que en la CGTA era posible encontrar a Walsh, con un pasado reciente vinculado a la formación de Prensa Latina, o a un dirigente sindical socialcristiano como Ongaro. A esto se sumaba que la central tenía contactos políticos con el Movimiento de Sacerdotes para el Tercer Mundo (MSTM) ${ }^{159}$ y con la revista Cristianismo y Revolución dirigida por Juan García Elorrio, en la cual se expresaban los sectores de filiación católica

\footnotetext{
154 "Hablan los estudiantes", en Semanario CGT, № 33, 12 de diciembre 1968. A pesar de los significados que otorgaban estudiantes como Grabois a la CGTA, no debe perderse de vista que aunque la línea peronista era la mayoritaria, la central de Ongaro predicó una amplitud ideológica, que dio lugar y reconocimiento a distintas corrientes políticas al interior de la central. Sotelo, L., Ob. cit, segundo semestre de 2012, p. 167.

${ }^{155}$ Sigal, S., Intelectuales y poder en la década del sesenta, Bs. As., Puntosur, 1991, p. 201.

156 Varias experiencias de militancia artística estuvieron vinculadas a la CGTA, como la del pintor Ricardo Carpani y la del Grupo Cine Liberación. Los dibujos y las películas se utilizaban como herramientas de formación o en las mismas actividades políticas.

${ }_{158}^{157}$ Solanas, F., y Getino, O., La Hora de los Hornos, Grupo Cine Liberación, 1968.

${ }^{158}$ Ibídem.

159 El mismo periódico de la CGTA reseñó los orígenes del MSTM. "Sacerdotes del Pueblo", en Semanario $C G T, \mathrm{~N}^{\circ}$ 33, 12 de diciembre 1968. Además publicó varias notas referidas a grupos o referentes católicos. Véase: $N^{\circ} 31,28$ de noviembre 1968; $N^{\circ} 35,29$ de diciembre 1968; $N^{\circ} 39,20$ de febrero 1969, entre otros.
} 
más identificados con la lucha revolucionaria en su vertiente armada ${ }^{160}$. Ambas experiencias, como la misma CGTA, estuvieron influenciadas por el cauce de politización que siguió una parte de la corriente posconciliar en la segunda mitad de los sesenta, cuando el sucesor de Juan XXIII, el Papa Paulo VI, inauguró una nueva etapa con la encíclica Populorum Progressio $^{161}$. En su artículo 31, llegaba afirmar que la insurrección violenta era justificada en dictaduras "evidentes y prolongadas".

\section{EL FIN DE LA CGTA Y EL SINFÍN DE SIGLAS DEL PERONISMO UNIVERSITARIO}

El año 1969 trajo grandes levantamientos populares en el interior de país que dejaron un saldo de tres estudiantes muertos: Juan José Cabral, Adolfo Bello y Luis Blanco. Si bien el foco estuvo puesto en las provincias y especialmente en lo que después se conoció como el Cordobazo, también hubo protestas porteñas en menor escala donde convergieron la CGTA con militantes enrolados en la FUA, el FEN y la UNE. El 27 de junio, un día antes del tercer aniversario de la dictadura, volvió a producirse una fuerte manifestación en Buenos Aires contra la visita oficial de Nelson Rockefeller, el gobernador de Nueva York que acudió al país en representación del presidente estadounidense Richard Nixon. La jornada dejó un saldo de más de cien detenidos y el asesinato de Emilio Jáuregui, el secretario general del Sindicato de Prensa. Lo paradójico fue que esta etapa de grandes protestas no sólo marcó el principio del fin de Onganía, sino también de la CGTA. Al día siguiente del entierro de Jáuregui y de la marcha de silencio realizada el 29 de julio, la central fue intervenida y sus principales dirigentes detenidos. Los sucesos se produjeron paralelamente al asesinato de Vandor por un desconocido comando guerrillero. A esto se sumaría en 1970, la realización de un nuevo congreso normalizador que, con el visto bueno de Perón, ungiría a José Ignacio Rucci y a Lorenzo Miguel como la nueva dirección unificada de la CGT.

En este contexto de fuertes manifestaciones y de desarticulación de la CGTA, la revista Cristianismo y Revolución publicó un documento del FEN y de la FUA, donde ambas organizaciones resaltaban los sucesos de mayo y junio de 1969 y tomaban posición ante el inminente IX Congreso Nacional de Estudiantes, el cual pretendía realizar la federación

\footnotetext{
${ }^{160}$ La revista Cristianismo y Revolución, declaradamente mensual -aunque en lo real fue algo más irregular, llegando a veces a ser quincenal- se publicó entre septiembre de 1966 y septiembre de 1971. Fue dirigida durante sus primeros veintidós números por García Elorrio, ex seminarista y líder del Comando Camilo Torres, una organización donde se formaron buena parte de los dirigentes de Montoneros. En sus números pueden encontrarse varias referencias a la CGTA, pero una nota importante fue la extensa entrevista que le realizaron a Ongaro en 1969, donde éste repasó el itinerario recorrido por su central. "Habla Ongaro", en Cristianismo y Revolución, $\mathrm{N}^{\circ} 13$, primera quincena abril 1969, pp. 14-24.

${ }^{161}$ Castro, F. y Salas, E., Ob. cit. 2011, p.31.
} 
reformista encabezada por Rocha a fines de ese mismo año ${ }^{162}$. En sus documentos, los dos sectores compartían que Onganía estaba en retroceso por la unión entre obreros y estudiantes, pero sostenían que era necesario unificar a estos últimos en una única entidad nacional. Lo que los diferenciaba era la forma de concretarla. Mientras la FUA, bajo la conducción del FAUDI, planteaba que su congreso era el punto de partida para lograr una unidad que se simbolizara en las figuras del "Che" Guevara y el cura guerrillero colombiano Camilo Torres; el FEN se negaba a aceptar que reclamase esa exclusividad porque no era la única tendencia del movimiento estudiantil. A su entender, frente a ella se había gestado una "línea nacional" donde confluían reformistas y católicos. Por esta razón, se debía encontrar una plataforma que expresara verdaderamente a todas las fuerzas, descartando el sello de la FUA.

Pese a las visiones de unos y otros, estos llamados a la unidad no tenían correlato en la práctica del movimiento estudiantil. La propia FUA se dividiría al poco tiempo y las agrupaciones nacionales o peronistas estaban fuertemente fragmentadas. El escenario de la UBA era representativo al respecto. Si bien Bárbaro y Grabois tuvieron gran protagonismo en la articulación con la CGTA, en esta experiencia también participaron agrupaciones como FANDEP, CENAP y JAEN. A esto se sumó que a principios de los setenta aparecieron nuevos nucleamientos universitarios que complejizaron aún más el panorama. Algunos surgieron a instancias de agrupaciones donde tenían un papel importante dirigentes gremiales que habían integrado la CGTA, como los Comandos Estudiantiles Peronistas (CEP), creados a instancias de la Organización Peronista 17 de Octubre que lideraba el sindicalista telefónico Julio Guillán ${ }^{163}$. A ellos se incorporaron varios militantes del Movimiento Humanista Renovador (MHR) de Filosofía y Letras, como Norberto Ivancich, Marcelo Cerviño y Susana Ramus $^{164}$. Otro caso fue el de la Agrupación de Estudiantes Peronistas (AEP), el frente universitario que impulsó el Movimiento Revolucionario Peronista (MRP). En su conducción tenía un rol destacado De Luca, dirigente del Sindicato Argentino de Obreros Navales que

\footnotetext{
162 "Hacia el Congreso Nacional de Unidad. La crisis del movimiento estudiantil. Llamamiento de la FUA (Federación Universitaria Argentina)", en Cristianismo y Revolución, $\mathrm{N}^{\circ}$ 22, enero de 1970, pp. 21-26; "Declaraciones del FEN (Frente Estudiantil Nacional)", en Cristianismo y Revolución, № 22, enero de 1970, pp. 32-34.

163 Guillán había creado en octubre de 1969 la Coordinadora de Agrupaciones Gremiales y Organizaciones Políticas Peronistas. En marzo del año siguiente, el grupo adoptó el nombre de Organización Peronista 17 de Octubre y creó sus frentes específicos de militancia. De esta manera, en la universidad surgieron los CEP. Bartoletti, J., Montoneros: de la movilización a la organización. Un caso paradigmático de militarización, Tesis Doctoral, UNSAM, 2010, p.207. Una reseña del surgimiento de los CEP, también puede encontrarse en: "Herederos de la práctica popular", en Primera Plana, N 488, 6 de junio 1972.

${ }^{164}$ Ramus, S., Sueños sobrevivientes de una montonera a pesar de la ESMA, Bs. As. Colihue, 2000, p. 14; Baschetti, R., La memoria de los de abajo 1945-2007, La Plata, De la Campana, 2007, Tomo I, p.121.
} 
actuó como secretario de prensa de la $\mathrm{CGTA}^{165}$.

Por otra parte, también aparecieron nuevos espacios a raíz de la escisión de agrupaciones ya existentes. Al fracturarse el JAEN en 1970, surgió la Fuerza para la Organización Revolucionaria Peronista (FORPE), la cual reunió a buena parte de los estudiantes de Derecho y de Filosofía y Letras que habían formado parte de los frentes universitarios dirigidos por Galimberti ${ }^{166}$. En suma, el fin de una década y el comienzo de otra, dejó en el tintero la desaparición de la CGTA y un variopinto de siglas en el peronismo universitario.

\section{IV - DOCENTES E INTELECTUALES EN LAS CÁTEDRAS NACIONALES}

Como venimos describiendo, los años posteriores a 1966 trajeron cambios en la situación del peronismo en la UBA. Sin embargo, sería un error reducir todo este proceso al movimiento estudiantil. A fines de los sesenta, surgieron las Cátedras Nacionales (CN) en la carrera de Sociología de la Facultad de Filosofía y Letras, una experiencia inesperada que involucró a docentes, intelectuales, jóvenes graduados y estudiantes avanzados. Lo primero a tener en cuenta es que las $\mathrm{CN}$ no fueron un proyecto colectivo planificado de antemano. La denominación surgió espontáneamente de una parte del alumnado que se sintió interpelado por un reducido número de materias, seminarios y actividades extracurriculares que explicitaban su adhesión al peronismo ${ }^{167}$.

La aparición de las $\mathrm{CN}$ nos retrotrae a la intervención universitaria decretada por Onganía el 29 de julio de 1966, ya que ellas están vinculadas al éxodo de profesores que se desató tras "La noche de los bastones largos". En la actualidad, algunos trabajos han señalado que es inadecuado sobredimensionar ese proceso y hablar de una "ola masiva de renuncias" en señal de protesta contra la dictadura. No sólo porque el resto de las universidades

\footnotetext{
${ }^{165}$ El origen del MRP puede situarse hacia agosto de 1963, cuando Perón -a través de Héctor Villalón- buscaba crear un contrapeso a la figura de Vandor. Su principal dirigente fue Gustavo Rearte, acompañado por sindicalistas como De Luca, Benito Romano, Juan Jonsch y Atilio Santillán. El MRP había logrado cierto predicamento en el ciclo de ocupaciones fabriles del Plan de Lucha de la CGT en 1964, donde sus militantes exaltaban las "tomas" porque veían en ellas "posibilidades insurreccionales" para impulsar el regreso de Perón a la Argentina. Según el MRP, el peronismo no tenía que institucionalizarse en un partido, sino impulsar un proceso de liberación nacional y social conducido por la clase obrera. A la agrupación de Rearte se la considera como uno de los núcleos fundacionales del peronismo revolucionario. No obstante, debe notarse que, por entonces, también funcionaba Acción Revolucionaria Peronista, el grupo fundado por Cooke a su vuelta de Cuba en 1963. Tortti, M. C., Ob. cit., 2009, pp. 364-365; Bozza, Ob. cit., 2014, p. 72.

${ }^{166}$ Larraquy, M., y Caballero, R., Ob. cit. 2011, pp. 115-116.

${ }^{167}$ Ghilini, A. y Dip, N., "Experiencias de peronización en la Universidad de Buenos Aires entre la dictadura de Onganía y el gobierno de Cámpora", en Revista Izquierdas, No 25, octubre 2015; Moscona, G., Peronismo e intelectuales. La experiencia de las Cátedras Nacionales en la Universidad de Buenos Aires en el período 19671974, Tesis de Maestría, FSOC, UBA, 2010, p.21. Por otra parte, todos los testimonios orales realizados a integrantes de las $\mathrm{CN}$ que iremos citando a lo largo del apartado coinciden en señalar que el nombre surgió de los mismos estudiantes.
} 
vivenciaron otros sucesos, sino porque en la misma institución porteña las reacciones fueron diversas $^{168}$. Sin embargo, en Filosofía y Letras fue amplia la deserción e incluso existieron varios profesores que optaron por continuar en sus cargos pero fueron cesanteados al finalizar el año, como el caso de Miguel Murmis, Eliseo Verón, Silvia Sigal y Manuel Mora y Araujo en el Departamento de Sociología ${ }^{169}$. Para ocupar estos espacios vacantes y crear un dique de contención al activismo político de la facultad, la intervención promovió el ingreso de profesores de la Universidad Católica Argentina (UCA). De esta manera, en 1967 arribaron dos docentes que ocuparían puestos importantes y serían los pilares de las $\mathrm{CN}$ en los años venideros: Justino O’Farrell y Gonzalo Cárdenas. El primero encabezó materias clave de la carrera de Sociología, como Introducción a la Sociología y Sociología Sistemática; mientras el segundo se hizo cargo de Historia Social Argentina. Sin embargo, ambos no fueron simples profesores, dado que en aquel entonces O'Farrell fue nombrado director del Departamento de Sociología y Cárdenas del Instituto de esa misma carrera.

En un primer momento, el activismo estudiantil de Filosofía y Letras -en su mayoría de izquierda y opositor a la dictadura- rechazó las figuras de O’Farrell y Cárdenas. Sin embargo, al poco tiempo los dos demostraron una amplitud ideológica que los situaba más cerca de corrientes posconciliares en diálogo con el marxismo y otras ideologías, que de un catolicismo cerrado y conservador. Sus trayectorias y antecedentes eran elocuentes al respecto. Cárdenas provenía de la DC, era graduado de economía de la UBA y se especializó en sociología e historia social en la Universidad de Lovaina de Bélgica, donde también había estudiado el cura colombiano Camilo Torres. En la primera mitad de los sesenta, dictaba clases en la Facultad de Ciencias Económicas y se sumó al Centro Argentino de Economía Humana (CAEH), una institución creada en 1963 bajo la influencia de Joseph Lebret. Este sacerdote dominico francés había fundado el Centro Latinoamericano de Economía Humana (CLAEH) en Montevideo y era uno de los principales impulsores del Concilio Vaticano II, con una prédica que reclamaba el compromiso ante la injusticia social y un trabajo teórico que

\footnotetext{
${ }^{168}$ Suasnábar sostiene que la coyuntura de 1966 está demasiado asociada a los hechos acaecidos en la UBA. La generalización de esta representación llevó al oscurecimiento de procesos particulares desarrollados en el resto de las universidades nacionales; pero, más importante aún, fue que acentuó una imagen de ruptura total de un hecho político que, sin minimizar su trascendencia, tuvo diferentes impactos en cada institución académica del país. Esta consideración debe ser tenida en cuenta para el caso de la UBA, debido a que no todas las casas de estudio porteñas experimentaron de la misma manera la intervención de Onganía. Suasnábar, C, Universidad e intelectuales. Educación y política en la Argentina (1955-1976), Bs. As., Manantial, 2004, p. 65-66; Buchbinder, P, Ob cit., 2010, p. 191.

${ }^{169}$ Entrevista a Silvia Sigal, La Plata, 29/10/2013; Rubinich, L., "La modernización cultural y la irrupción de la sociología”, en James, D. (comp.), Violencia, proscripción y autoritarismo (1944-1976), Bs. As., Sudamericana, 2007, pp. 260-261.
} 
buscaba "desatanizar" al marxismo para sintetizarlo con el pensamiento cristiano ${ }^{170}$. En la Argentina, el $\mathrm{CAEH}$ era un centro de investigación que realizaba conferencias $\mathrm{y}$ publicaciones. Tenía conexiones con el MHR de Filosofía y Letras y la Asociación Sindical Argentina (ASA), que en ese entonces integraba la CGT. Esto le permitió a Cárdenas dictar cursos de capacitación sindical en la central obrera y dirigir la revista Cambio, una publicación que realizaban universitarios del $\mathrm{CAEH}$, donde no sólo habían referencias a Lebret, sino que también se hablaba de la necesidad de crear una "universidad nueva" en una "argentina liberada" 171 .

O'Farrell, por su parte, era un sacerdote jesuita que había realizado un posgrado en sociología en los Estados Unidos, con una fuerte orientación funcionalista. En sus viajes a Europa había tomado contacto con el pensamiento católico renovador que irradiaban centros como la Universidad de Lovaina ${ }^{172}$. Junto con Cárdenas, había formado parte del plantel docente que seleccionó José Enrique Miguens para fundar en 1959 la segunda carrera de Sociología del país en la Facultad de Ciencias Sociales y Económicas de la UCA ${ }^{173}$; O’Farrell estuvo a cargo de la materia Cambio Social y Cárdenas de Historia Social Argentina. Esta experiencia terminó abruptamente en 1966 cuando Miguens debió renunciar frente a la presión de los sectores conservadores de la UCA, fortalecidos tras la llegada de Onganía al $\operatorname{poder}^{174}$. Uno de los acontecimientos que desencadenó este hecho, fue que Miguens se negó a despedir a un grupo de profesores que se manifestaron contra la injerencia estadounidense en Vietnam. A esto se sumaba que docentes fueron amonestados y estudiantes suspendidos por posicionarse contra la intervención de las universidades estatales. Cuando Miguens se retiró, Cárdenas renunció con la mayor parte del equipo docente del Departamento de Sociología en solidaridad con él. O’Farrell continuó en su cargo, pero fue cesanteado al poco tiempo ${ }^{175}$.

\footnotetext{
${ }^{170}$ Donatello, L.M., Catolicismo y Montoneros, Bs.As., Manantial, 2010, pp. 53-54

${ }^{171}$ Pueden encontrarse documentos del CAEH y una reseña de su historia en: Mayol, A., Habegger, N., y Armada, A., Los católicos posconciliares en la Argentina, Bs. As., Galerna, 1970, pp. 127-128.

172 Zanca, J., Los intelectuales católicos y el fin de la cristiandad 1955-166, Bs.As., FCE, 2006, p.192.

${ }^{173}$ Miguens se graduó de abogado, pero se especializó en Sociología Económica con Talcott Parsons y Pitirim Sorokin en Estados Unidos. Durante los primeros gobiernos de Perón se desempeñó como docente de sociología en la UBA. En 1959, fue convocado por Monseñor Octavio Derisi para organizar y dirigir un Departamento de Sociología en la UCA. Entre los alumnos que pasaron por las aulas de Miguens, podemos nombrar a Atilio Borón, Juan José Llach y Carlos Prego. Aramburu, L. y Giorgi, G., "Recuperando trayectorias olvidadas: José Enrique Miguens, sociólogo", en Primer Congreso de Sociólogos de la Provincia de Buenos Aires, 2013.

${ }^{174}$ Suárez, F. "Algunas reflexiones sobre los procesos de institucionalización de la Sociología en la Argentina durante los últimos años”, en Revista Mexicana de Sociología, №1, enero-marzo, 1973.

${ }^{175}$ Aramburu, L. y Giorgi, G., Ob. cit. 2013; Zanca, J., Ob. cit. 2006, pp.197-206. En 1973 el diario La Opinión repasó la trayectoria de O'Farrell de la siguiente manera: “El doctor O'Farrell ha recibido títulos académicos en las universidades de Jordan y Berkeley, de los Estados Unidos, de Lovaina, Bélgica, y Gregoriana, de Roma. Fue profesor de sociología en la UCA de Buenos Aires hasta agosto de 1966. Entonces el rectorado lo separó de su cátedra por haberse pronunciado contra la intervención a las universidades, dictada por el gobierno de Juan Carlos Onganía". Véase: "Nuevos decanos en siete facultades", en La opinión, 31 de mayo 1973.
} 
Como vemos, el mundo católico de donde provenían Cárdenas y O’Farrell era complejo y poco lineal. No obstante, lo que describimos anteriormente no termina de explicar su arribo a cargos docentes y de gestión en Filosofía y Letras. Una hipótesis probable es que en 1967 hayan sido promovidos por sectores vinculados al ministro del interior Guillermo Borda y al subsecretario de educación Emilio Mignone. Ambos habían ocupado espacios de gestión durante el primer peronismo y el segundo tenía una larga militancia en el movimiento católico $^{176}$. De todas maneras, si la idea de Borda y sus funcionarios fue incorporar a docentes de la UCA con la intención de desplazar el exceso de politización y todo lo que asociaban a izquierda en la universidad, en el caso de Cárdenas y O'Farrell no tuvieron el resultado esperado. Al poco tiempo de su arribo a Filosofía y Letras, sumaron a sus cátedras y dieron lugar en materias optativas o seminarios extracurriculares a un conjunto de estudiantes avanzados y jóvenes graduados que en muchos casos provenían de una militancia de izquierda. La mayor parte eran de la carrera de Sociología, aunque también hubo algunos de Filosofía y Antropología.

Un núcleo vinculado a la primera disciplina era el de Roberto Carri, Susana Checa, Alcira Argumedo y Horacio González. En sus primeros años de estudio habían participado en las protestas para que introdujeran autores marxistas en los programas de las materias, como en la recordada huelga contra Metodología de la Investigación Social en $1962^{177}$. En aquel momento la carrera de Sociología seguía encabezada por quien la había fundado en 1957: Gino Germani ${ }^{178}$. El joven Carri había empezado a militar en la segunda mitad de los cincuenta en la FJC. A principios de la década siguiente, se vinculó al Círculo de Estudios Sociales Luis E. Recabarren que editaba la revista El Obrero $^{179}$. Luego, a mediados de los

176 Entrevista a Jorge Carpio, C.A.B.A., 20/11/2015 y 30/10/2015; entrevista a Susana Checa, C.A.B.A., 22/12/2015. Por su parte, Villanueva también sugiere que Cárdenas tuvo contactos con Jorge Salimei, el primer ministro de Economía de Onganía. Ambos habían sido militantes de DC y eran graduados de la Facultad de Ciencias Económicas de la UBA. Entrevista a Ernesto Villanueva, Florencio Varela, 04/05/2014 y 17/09/2014. En relación a este tema, también pueden consultarse algunas referencias breves en: Moscona, G., Ob. cit., 2010, p.17.

${ }^{177}$ La cátedra estaba a cargo de la profesora Regina Gibaja, una de las docentes del grupo cercano a Gino Germani. La protesta de los alumnos consistió en no presentarse a rendir exámenes bajo el eslogan: "contra el empirismo abstracto". Según Argumedo, la crítica central era a los planes de estudio que sólo incorporaban textos de "funcionalistas o del empirismo norteamericano". Argumedo, A., "Roberto Carri", en Carri, R., Roberto Carri: obras completas, Bs. As., Biblioteca Nacional, 2015, Tomo I, p. 24; "Entrevista a Alcira Argumedo", en González, H., Historia crítica de la Sociología argentina. Los raros, los clásicos, los científicos, los discrepantes, Bs. As., Colihue, 2000 p. 482; "Nacional y popular" [Entrevista a Alcira Argumedo], en Política, cultura y sociedad en los '70, $\mathrm{N}^{\circ} 10,1998$.

${ }^{178}$ La carrera de Sociología fue creada en la UBA en 1957, en la UCA dos años más tarde y en la Universidad del Salvador en 1963. Después del golpe militar de 1966, la carrera se inauguró en otras universidades del interior del país. Pero las tres primeras instituciones siguieron siendo dominantes y se repartían el 90 por ciento de los alumnos hacia 1969. Rubinich, L., Ob. cit. 2007, p.252.

${ }^{179}$ Duhalde, E. L., “Apropósito de Carri y de su obra”, en Carri, R., Isidro Velázquez, Bs.As., Colihue, 2011, p. 139. 
sesenta, tuvo un paso por el Ministerio de Trabajo y dirigió la revista Estudios Sindicales, donde participaron como editores Rodolfo Ortega Peña y Eduardo Luis Duhalde, por entonces jóvenes abogados laboralistas y asesores legales de la $\mathrm{UOM}^{180}$. Ambos habían hecho sus primeros pasos militantes en espacios no peronistas. Ortega Peña en el PC tras una primera aproximación al radicalismo frondicista y Duhalde en el humanismo. En los tempranos sesenta habían realizado su pasaje al peronismo y mantenido contactos con distintos actores del sindicalismo y la izquierda nacional ${ }^{181}$. Tras el golpe de Onganía, Carri también integró otro emprendimiento del dúo Peña-Duhalde: el Centro de Cultura Nacional Carlos Guido Spano. Desde ahí organizaron la editorial Sudestada que publicó su primer libro en 1967: Sindicatos y poder en la Argentina. Como si esto fuera poco, luego de ese año Carri se sumó al JAEN. Al mismo Galimberti lo había conocido por frecuentar ambos el estudio jurídico de Ortega Peña y Duhalde ${ }^{182}$.

Por su parte, González, Argumedo y Checa también habían iniciado su militancia política en la UBA desde la izquierda, pero en las filas del TAU. En un apartado anterior señalamos que esta organización estudiantil respondía al MIRA, una fracción del grupo Praxis de Silvio Frondizi que encabezó Torres Molina en 1961, alegando la necesidad de una ideología revolucionaria y nacionalista que comprendiera mejor al peronismo. González, Argumedo y Checa siguieron el itinerario del TAU que derivó en la constitución del FAU, a raíz de su alianza con el LIM de Grabois y Hopen ${ }^{183}$. Luego del golpe de 1966, al menos González integró por un breve tiempo el FEN, en sus etapas finales como estudiante y primeros pasos como graduado ${ }^{184}$. Como mostramos, esta agrupación de pasaje al peronismo encabezada por Grabois se había formado en 1967 con varios militantes del FAU, algunos provenientes del LIM y otros del TAU.

Al FEN también se sumaron brevemente otros futuros integrantes de las $\mathrm{CN}$ que estudiaron sociología, pero que no habían realizado los mismos pasos previos que los ya

\footnotetext{
${ }^{180}$ Estudios Sindicales tenía una periodicidad quincenal y fue publicada entre octubre de 1966 y febrero de 1967. Carri firmaba con su apellido materno: Cappagli. La misma dio cuenta, entre otros acontecimientos, de la primera huelga general a la dictadura -el 14 de diciembre de 1966- y de las primeras discusiones acerca del posicionamiento frente al gobierno militar. Asimismo, brindó información de distintos conflictos obreros, especialmente de las ramas industriales afectadas por la política de racionalización económica de la dictadura. Además, proporcionaba información sobre distintas actividades de la CGT. Nassif, S. y Dawyd, D., "La revista Estudios Sindicales de Roberto Carri. Un documento para el estudio de la clase obrera de los sesenta", en Corpus, Vol. 4, No 2, 2014.

${ }^{181}$ Tarcus, H., Ob. cit., 2007, p. 306.

182 Larraquy, M. y Caballero, R., Ob. cit. 2011, p. 69.

183 Entrevista a Alcira Argumedo, C.A.B.A., 01/11/2012; Entrevista a Susana Checa, C.A.B.A., 22/12/2015; "Éramos como hojas en la tormenta" [Entrevista a Horacio González], en Política, cultura y sociedad en los '70, $\mathrm{N}^{\circ} 10,1998$.

${ }^{184}$ Trímboli, J., La izquierda en la Argentina, Bs. As., Manantial, 1998, p. 78; Feinmann, J.P., y González, H., Historia y pasión, Bs. As., Planeta, 2013, p.73; Grabois, R., Ob. cit. 2014, p.150.
} 
nombrados. Uno era Ernesto Villanueva; por haber cursado un tiempo en la Facultad de Ciencias Economías hizo su ingreso al FEN por la vía de RR, la agrupación estudiantil reformista encabezada por Peola ${ }^{185}$. Otro era Juan Pablo Franco, quien luego de haber participado en actividades del MHR y de un paso fugaz por ANDE, recaló en el FEN. A mediados de los sesenta, también realizó militancia barrial con grupos peronistas en la zona sur del Gran Buenos Aires, junto a Argumedo y otros estudiantes de sociología que serían integrantes de las CN, entre los que estaban Pedro Krotsch y Fernando Álvarez, el hermano mayor de Carlos, el estudiante de historia que en ese tiempo militaba en JAEN y luego integraría FORPE ${ }^{186}$.

Una trayectoria bastante particular vinculada a la carrera de Sociología que recaló en las $\mathrm{CN}$, fue la de Jorge Carpio. En los cincuenta había venido de Perú, su país natal, a terminar la escuela secundaria en La Plata. A fines de esa misma década, inició su militancia política en la FJC y una vez en la facultad integró la Agrupación Reformista de Estudiantes de Medicina (AREM). Además, en ese tiempo estudió paralelamente Filosofía y formó parte de Amauta, una agrupación política de estudiantes peruanos que residían en la Argentina, en la cual había partidarios del APRA Rebelde y del PC $^{187}$. Desde esa organización entabló relaciones con sectores sindicales platenses relacionados a Cooke y al peronismo revolucionario. Por estos contactos, Carpio ingresó a Acción Revolucionaria Peronista (ARP) y en paralelo intentó sumarse a la fallida incursión guerrillera del Ejército Nacional de Liberación de Perú en $1965^{188}$. De vuelta al país, participó en la conformación de la Federación Universitaria para la Revolución Nacional (FURN) hasta irse a estudiar sociología a la capital porteña, carrera que pudo terminar rápidamente por habérsele reconocido equivalencias en sus estudios de filosofía previos ${ }^{189}$.

Entre quienes se incorporaron a las $\mathrm{CN}$ había un conjunto de sociólogos que eran "peronistas de primera hora". Por procedencia familiar, como el caso de Ricardo Sidicaro, o

\footnotetext{
185 Entrevista a Ernesto Villanueva, Florencio Varela, 04/05/2014 y 17/09/2014; "La transición permanente" [Entrevista a Ernesto Villanueva], en Política, cultura y sociedad en los '70, $\mathrm{N}^{\circ}$ 10, 1998.

${ }^{186}$ Entrevista a Juan Pablo Franco, C.A.B.A., 18/10/2016.

${ }^{187}$ El APRA Rebelde era un desprendimiento de la Alianza Popular Revolucionaria Americana (APRA) de Raúl Haya de la Torre. Esta facción fue liderada por Luis De la Puente Uceda y cerca de mediados de los sesenta pasó a llamarse Movimiento de Izquierda Revolucionaria. Por sus vínculos con Cuba, De la Puente Uceda entabló contactos con Cooke. Tortti, M. C., Ob. cit., 2009, pp. 348-349. Pueden encontrarse referencias a Amauta en Amato, F. y Boyanovsky Bazán, C., Setentistas. De La Plata a la Rosada, Bs. As., Sudamericana, 2009 , p. 40.

${ }^{188}$ ARP fue fundada por Cooke en 1963 luego de su viaje a Cuba, con la intención de generar una organización de cuadros que sea capaz de orientar al movimiento peronista hacia estrategias insurreccionales y armadas. En su estancia en la isla, Cooke también entabló contactos con otros militantes latinoamericanos, los cuales impulsaron focos guerrilleros en sus respectivos países para acompañar la estrategia continental del "Che" en América Latina. Cersósimo, F., Envar El Kadri. Historias del peronismo revolucionario, Bs.As., Colihue, 2008, p. 193.

${ }^{189}$ Entrevista a Jorge Carpio, C.A.B.A., 20/11/2015 y 30/10/2015
} 
por haber comenzado a militar desde un inicio en organizaciones estudiantiles de ese signo político, como Lelio Mármola en la JUP y Enrique Pecoraro y Néstor Momeño en FANDEP $^{190}$. Por otra parte, resulta relevante considerar a quienes ingresaron a las $\mathrm{CN}$ pero proviniendo de otras carreras, como Norberto Wilner, Gunnar Olsson, Amelia Podetti y Guillermo Gutiérrez. Los tres primeros eran de Filosofía. Wilner había sido uno de los líderes del TAU junto a Juan Samaja. A esta agrupación también ingresó Olsson aunque de manera mucho más periférica a como lo había hecho Wilner. Amelia Podetti, por su parte, en la segunda mitad de los cincuenta se había licenciado en Filosofía y afiliado al Partido Justicialista (PJ). Llegó a las CN con una gran formación por haber profundizado sus estudios a principios de los sesenta en la Universidad de París y en el Institut Catholique de Francia ${ }^{191}$. Finalmente, Gutiérrez era graduado de Antropología. En su tiempo de estudiante había adherido a ANDE, luego de unos orígenes militantes vinculados a la izquierda ${ }^{192}$.

Las trayectorias descriptas no deben hacer pensar que las $\mathrm{CN}$ fueron un colectivo constituido de antemano al que fueron integrándose distintos actores. Al contrario, toda esta experiencia se desarrolló paulatinamente y comenzó a materializarse a fines de los sesenta. Los que jugaron un papel central en ella fueron O'Farrell y Cárdenas porque desde el Departamento de Sociología permitieron posicionarse como docentes y ayudantes a un conjunto de personas que en su mayoría eran jóvenes graduados. En un primer momento, los agruparon en cada una de sus cátedras. Así, de la mano de O'Farrell se pudieron vincular Carri, Wilner, Olsson, Carpio, Checa, Argumedo, González y Sidicaro al espacio de Sociología Sistemática y a las optativas afines tituladas Problemas de Sistemática. Mientras que, por otra parte, Villanueva, Franco y Álvarez integraron el área de Cárdenas, la cual estaba compuesta por Historia Social Argentina y optativas como Problemas Socioeconómicos Argentinos y Sociología de América Latina. Luego de los primeros acercamientos, se fueron ampliando estos espacios con otros ayudantes, docentes, cátedras y seminarios extracurriculares ${ }^{193}$. Lo que terminó de gestar un ámbito donde convergieron

\footnotetext{
${ }^{190}$ Entrevista a Lelio Mármola realizada por Aritz Recalde, C.A.B.A., 23/06/2006.

${ }^{191}$ Denaday, J.P., "Amelia Podetti: una trayectoria olvidada de las Cátedras Nacionales", en Nuevo Mundo Mundos Nuevos, 2013.

${ }^{192}$ Entrevista virtual a Guillermo Gutiérrez, 29/11/2016; Gutiérrez, G., "Antropología 3er Mundo. Cuatro décadas, algunas reflexiones sobre el contexto de origen”, en Antropología 3er. Mundo, Edición facsimilar FFyL, UBA, 2009, p. 11.

${ }^{193}$ Pueden consultarse los siguientes programas de las CN: Programa No 109, Conflicto Social, UBA, FFyL, primer cuatrimestre 1968; Programa $\mathrm{N}^{\circ} 112$, Problemas socioeconómicos argentinos I, UBA, FFyL, primer cuatrimestre 1968; Programa N $\mathrm{N}^{\circ} 113$, Problemas socioeconómicos de América Latina, UBA, FFyL, primer cuatrimestre1968; Programa No 115, Sociología Sistemática, UBA, FFyL, primer cuatrimestre 1968; Programa $\mathrm{N}^{\circ} 116$, Problemas socioeconómicos argentinos II, UBA, FFyL, segundo cuatrimestre 1968; Programa $\mathrm{N}^{\mathrm{o}} 117$, Sociología de América Latina, UBA, FFyL, segundo cuatrimestre 1968; Programa No 68, Problemas de Sistemática, UBA, FFyL, primer cuatrimestre 1969; Programa $\mathrm{N}^{\circ}$ 153, Nación y Estado, UBA, FFyL, primer
} 
trayectorias vinculadas a la izquierda, el peronismo y el catolicismo.

Todo este recorrido deja sin responder una pregunta relevante ¿cómo eran las lecturas de las CN sobre las ciencias sociales, la sociología y la historia para poder articular itinerarios diversos y permitir que los propios estudiantes las nominaran "Cátedras Nacionales"? Una buena forma de abordar este interrogante es considerando tres libros que fueron publicados en los primeros momentos de la experiencia: 1)- Isidro Velázquez. Formas prerrevolucionarias de la violencia; 2)- Ser social y Tercer Mundo (Elementos para una lógica de lo nacional); y 3)- Las luchas nacionales contra la dependencia. El primero data de 1968 y fue el segundo libro de Carri, publicado bajo el sello Sudestada de Ortega Peña y Duhalde ${ }^{194}$. El siguiente trabajo lo editó Galerna en 1969. Era la tesis de licenciatura en filosofía de Wilner ${ }^{195}$. El tercero, también publicado por esa misma editorial en 1969, era un extenso escrito de Cárdenas para su cátedra de Historia Social Argentina ${ }^{196}$.

Nombramos estas obras porque más allá de sus particularidades, en ellas se expresa claramente el discurso político-intelectual que tejieron las $\mathrm{CN}$ para legitimar su existencia y sus intervenciones. El mismo consistía en cuatro grandes tópicos relacionados entre sí: 1)Reducía la trayectoria anterior de la carrera de sociología a una disputa entre herederos del funcionalismo estadounidense y de la izquierda tradicional. 2)- Señalaba que ambas corrientes eran incapaces de comprender la situación particular de Argentina y América Latina, porque partían de una visión eurocéntrica que era deudora de la vieja dicotomía sarmientina de civilización o barbarie; como lo demostraban el esquema funcionalista de pasaje de la

cuatrimestre 1971. Todas las optativas de las CN eran presentadas en los planes de estudio como "Sociologías Especiales".

${ }^{194}$ Carri, R., Isidro Velázquez. Formas prerrevolucionarias de la violencia, Bs.As., Colihue, 2011. En este trabajo, Carri traza las primeras pinceladas críticas referidas al rol del sociólogo. La historia de este peón rural que sufrió el hostigamiento policial y fue acusado de producir hechos delictivos, le suministra material para pensar las "formas violentas de protesta que no adoptan manifiestamente un contenido político pero que indudablemente lo tienen". Retomando a Sarmiento y a Frantz Fanon, Carri se opone a calificar a Velázquez como "bandolero social", una categoría utilizada por Eric Hobsbawm para indicar formas "primitivas" de protesta social en las sociedades campesinas europeas. Para el autor, si los sociólogos utilizan acríticamente conceptos exportados, pueden perder de vista experiencias de lucha política que "forman parte de la cultura autónoma de un pueblo". Nahmías, G., "Roberto Carri: el pensamiento soslayado. Estudio preliminar", en Carri, R., Roberto Carri: obras completas, Bs. As., Biblioteca Nacional, 2015, Tomo I, pp. 43-45.

${ }^{195}$ Wilner, N., Ser Social y Tercer Mundo (Elementos para una lógica de lo nacional), Bs. As., Galerna, 1969. Este libro involucró a otros dos integrantes de las CN: al director de tesis, O’Farrell, y a Podetti, la prologuista. En este trabajo, Wilner retoma el concepto de "ser social" que propone Karl Marx en el "Prólogo de la Contribución a la Crítica de la Economía Política", para indagar si es posible pensar a través suyo la lógica del "ser nacional". Ibídem, p.43.

${ }^{196}$ Cárdenas, G., Las luchas nacionales contra la dependencia, Bs.As., Galerna, 1969. En este libro, Cárdenas se propone el abordaje de una "historia social argentina" desde un "nuevo enfoque sociológico" que vincule el examen de las clases sociales y los movimientos nacionales. En él recurre a un sinfín de trabajos que van desde Germani, Fanon, Fernando Cardoso, Peter Worsley, Andrew Gunther Frank, hasta Milcíades Peña, José Carlos Mariátegui y José Luis Romero. En el cuarto capítulo, reconstruiremos los contactos vinculados a Galerna que permitieron la publicación de los libros de Wilner y Cárdenas. 
sociedad tradicional a la moderna y las teorías marxistas que sólo abordaban el conflicto social desde la contradicción burguesía-proletariado. 3)- Consideraba al propio trabajo de las CN como pionero de un nuevo enfoque "nacional" y "tercermundista" en el ámbito de la sociología y las ciencias sociales argentinas, debido a que no pasaba por alto la oposición fundamental entre imperialismo-nación 4)- Afirmaba a partir de esta perspectiva que el movimiento de liberación nacional y social propio de la Argentina era el peronismo.

Desde ya que estas posturas no hacían justicia con el breve pero intenso desarrollo que había tenido la carrera de Sociología en Filosofía y Letras. Tampoco era una novedad de las $\mathrm{CN}$ la introducción de la cuestión nacional, la dependencia y el tercer mundo. Este planteo de una u otra forma podía encontrarse en distintos intelectuales vinculados a la izquierda y el peronismo $^{197}$. Sin embargo, la experiencia que encabezaron Cárdenas y O’Farrell brindó un espacio concreto a estudiantes y jóvenes graduados que por sus propios itinerarios previos estaban ávidos de escuchar esos tópicos discursivos y por definir su pasaje al peronismo. Si la CGTA ofreció una opción concreta en el ámbito político para tramitar ese tránsito, las CN lo hicieron en el plano mismo de la academia y la discusión intelectual. Pese a que presentamos esquemáticamente sus posiciones, el estudio socio-historiográfico de Cárdenas, la puesta en primer plano de la figura de Isidro Velázquez por Carri y el análisis del concepto de ser social en la obra de Marx realizado por Wilner, eran trabajos argumentados que incluían una extensa batería de citas y conceptos teóricos. Por esta razón, fueron herramientas largamente aprovechadas por la militancia estudiantil peronista o en tránsito de peronización.

\section{V - SER UNIVERSITARIO PERONISTA EN LOS SESENTA}

Como argumentamos a lo largo del capítulo, la situación del peronismo en la UBA comenzó a modificarse luego del golpe de 1966. Lentamente surgieron nuevos agrupamientos universitarios que adhirieron o mostraron amplias simpatías por ese movimiento. La mayoría

\footnotetext{
${ }^{197}$ Estas lecturas de los jóvenes intelectuales peronistas que concebían al movimiento como una vía para encarar la liberación nacional y la revolución social eran en buena medida deudoras de la producción intelectual de Juan José Hernández Arregui, John William Cooke y Rodolfo Puiggrós. Este último caracterizaba a este tipo de enfoques como "nacionalismos populares revolucionarios". Los trabajos actuales difieren en la manera de catalogar a estos referentes político-intelectuales. Mientras Georgieff sitúa a Puiggrós y Hernández Arregui dentro de la tradición de la izquierda nacional; Acha sostiene que Cooke y Hernández Arregui fundaron una visión y una historiografía propia de la izquierda peronista, la cual se distinguía tajantemente de la izquierda nacional. Más allá de las clasificaciones, en sus análisis todos mixturaban el marxismo, el nacionalismo y el peronismo. Para profundizar estos debates, véase: Georgieff, G., Nación y revolución. Itinerarios de una controversia en Argentina (1960-1970), Bs.As., Prometeo, 2008, pp.80 y 89; Acha, O., Historia Crítica de la historiografia argentina. Vol. 1: las izquierdas en el siglo XX, Bs.As., Prometeo, 2009, p.307. En relación a la caracterización de "nacionalismo popular revolucionario", puede consultarse: Puiggrós, R., "Tesis sobre el Nacionalismo Popular Revolucionario", en Las Izquierdas y el Problema Nacional, Bs.As., Ediciones Cepe, 1973, pp.187-194.
} 
de sus fundadores eligieron la palabra "nacional" para nombrar a estos espacios o en algunos casos optaron por identificarse directamente como "peronistas". En retrospectiva, es necesario preguntarse por el significado de esta experiencia. Varios relatos de la época e investigaciones actuales señalan que la intervención de Onganía fue un antes y después, dado que a partir de ahí fue desplegándose una creciente peronización de estudiantes, docentes e intelectuales. Un buen punto de partida es poner en cuestión esta afirmación general, para abordar las particularidades del panorama porteño. Lo primero que se desprende del análisis que realizamos entre 1966 y 1970 es que no debe exagerarse la idea de "parte aguas" en relación a la intervención de Onganía. Varios de los universitarios que formaron parte de las nuevas agrupaciones provenían de sectores reformistas y católicos que habían abandonado sus posturas antiperonistas antes del golpe e incluso acompañaron activamente a la CGT en su Plan de Lucha de 1964.

Otro tema importante es no sobredimensionar la peronización y tampoco abordarla como un proceso ineluctable. El surgimiento de grupos como el FEN, UNE, CENAP, JAEN, CEP y las CN si bien cambió la situación del peronismo en relación a los viejos tiempos de la CGU y la JUP, estuvo lejos de convertirlo en hegemónico en la UBA. A decir verdad, a fines de los sesenta sus organizaciones estudiantiles estaban fuertemente fragmentadas y las $\mathrm{CN}$ eran una experiencia anclada en Filosofía y Letras. Ellas mismas afirmaban esto en un documento que difundieron en diciembre de 1969, donde reconocían que eran una minoría en la facultad y hasta en la propia carrera de Sociología ${ }^{198}$. De todos los grupos que nombramos, el que más peso y visibilidad tuvo en ese momento fue el FEN, aunque no logró articular detrás de sí al resto de siglas del peronismo universitario. El espacio que terminó cumpliendo esa función de enlace fue la CGTA que encabezó Ongaro, la cual coordinó varias acciones conjuntas con estos grupos y la FUA, a medida que crecía el frente opositor a la dictadura en 1968 y, sobre todo, al año siguiente con el Cordobazo y otros levantamientos populares en el interior del país. Pero más allá de esta cuestión, en el caso particular de la UBA no sería adecuado caracterizar a la peronización de esos años como un proceso de adhesión masiva de estudiantes, docentes e intelectuales al peronismo.

A esta problemática se suma lo inadecuado de describir el pasaje al peronismo en términos generales y sin aclarar su orientación. La nacionalización y la peronización de los núcleos universitarios que abordamos eran bien específicas. Ellos no pedían volver a los primeros gobiernos peronistas, ni crear la comunidad organizada. Su idea de ser nacionales y

\footnotetext{
198 "Sociología: Instrumento de conocimiento y de lucha", diciembre 1969. Reproducido en Cristianismo y Revolución, $\mathrm{N}^{\circ} 22$, enero 1970.
} 
de ser peronistas estaba íntimamente ligada a ser antiimperialistas y socialistas. El ideario de un nacionalismo revolucionario anclado en el concepto de liberación no era nuevo. Antes de 1966 existían expresiones universitarias donde estos enfoques eran recurrentes. Pero lo particular de los grupos como el FEN, UNE, JAEN, CENAP y otros, era que tramitaron esa nacionalización mediante su peronización. A su entender, el peronismo era la única opción política que podía concretar esos horizontes tercermundistas y revolucionarios. En este punto, fueron importantes las producciones de las $\mathrm{CN}$ porque generaron nuevos aportes políticointelectuales para argumentar estas posiciones. No obstante, la que también jugó un papel clave fue la CGTA porque les ofreció un espacio concreto para converger con sectores de la clase obrera en la oposición a la dictadura, desde un programa que mixturaba peronismo, cristianismo posconciliar y medidas con tintes anticapitalistas ${ }^{199}$.

En este marco, las experiencias de peronización porteñas pueden ser entendidas como un caso particular de la configuración de la nueva izquierda argentina en los sesenta. Los estudiantes, docentes e intelectuales que tramitaron su pasaje al peronismo, lo hicieron dentro de un heterogéneo conglomerado de fuerzas sociales y políticas que vinculó su oposición a la dictadura con la posibilidad de introducir cambios más amplios. A pesar de las precauciones que marcamos en párrafos anteriores, no hay que subestimar la idea de que la intervención de Onganía generó las condiciones para que más universitarios formaran parte de esa politización; dado que al prohibir la política y el gobierno tripartito cerró canales de diálogo y participación, en un país donde además estaba proscripto el movimiento político mayoritario. Alain Touraine, en un trabajo de 1969, señaló que en los sistemas políticos donde no hay instancias de negociación intermedia, existen más posibilidades de que los universitarios trasciendan su espacio particular y se lancen a una acción directamente política ${ }^{200}$. La pregunta que queda abierta para el capítulo siguiente es si la peronización porteña también impulsó nuevos discursos sobre la universidad y el movimiento estudiantil.

\footnotetext{
${ }^{199}$ Cavarozzi reconoce que más allá de la desaparición de la CGTA, su discurso de oposición frontal al régimen de Onganía fue acentuando los contenidos anticapitalistas y proporcionó material ideológico como "práctico", disponible para ser apropiado por otros protagonistas en acciones colectivas de distinta índole. Cavarozzi, M., Autoritarismo y Democracia, Bs. As., CEAL, 1983, p. 42.

${ }^{200}$ Touraine, A., La sociedad post-industrial, Barcelona, Ariel, 1969, pp.127-128.
} 
EN BUSCA DE UN RELATO PARA LA UNIVERSIDAD

DE ANTRopología 3ER. MUNDO A LOS CUERPOS DE DELEGAdOS

1968-1972

En este segundo capítulo indagamos la manera en que abordaron la cuestión universitaria los grupos de estudiantes, docentes e intelectuales peronizados entre 1968 y 1972. Comenzamos con una introducción sobre cómo interpretaron algunos intelectuales de la época la disolución del viejo desencuentro entre peronismo y universidad. Luego tomamos como referencia a la revista Antropología 3er. Mundo para analizar los debates sobre la cuestión universitaria que entablaron peronistas con otros actores académicos, políticos y culturales de aquel entonces; haciendo hincapié en la significación particular que otorgaron a la Reforma de 1918 y a la gestión universitaria del primer peronismo. La periodización de este capítulo tiene dos momentos importes: la aparición de Antropología 3er. Mundo a fines de los sesenta y la desaparición de las Cátedras Nacionales junto a la irrupción de los cuerpos de delegados en la UBA a principios de la década siguiente.

\section{I - NUEVOS PERONISTAS, NUEVAS DISCUSIONES}

Juan José Hernández Arregui publicó la segunda edición de La formación de la conciencia nacional en 1970, un año signado por las grandes revueltas sociales que se habían desatado en el interior del país. En la nueva publicación de su obra, agregó un anexo donde señalaba que la argentina de los sesenta había entrado en un período de convulsión revolucionaria. Los tres acontecimientos más notorios de estas crisis eran la exclusión del peronismo de la vida política nacional, la insubordinación de la clase obrera ante dirigencias burocráticas y el cambio ideológico de la clase media, evidenciado en la convergencia de estudiantes con trabajadores y en la aparición de organizaciones ilegales que ligaban su acción a la resistencia de $\operatorname{masas}^{201}$. Para el antiguo dirigente del movimiento CONDOR $^{202}$, el cambio

${ }^{201}$ Hernández Arregui, J. J., La formación de la conciencia nacional, Bs. As., Ediciones Continente, 2004, p.390.

${ }_{202}$ Los Centros Organizados Nacionales de Orientación Revolucionaria (CONDOR) surgieron en 1964 por iniciativa de Hernández Arregui. Eran una agrupación que se definía como peronista revolucionaria, en la que 
político de los sectores medios era uno de los hechos más decisivos de la década y se expresaba, especialmente, en la nacionalización de sus fracciones universitarias ${ }^{203}$. Esta trasformación no había surgido abruptamente. En la primera edición de su trabajo, el mismo Hernández Arregui señalaba que el estudiantado venía experimentado una lenta reorientación ideológica desde fines de los cincuenta. Durante esos años, algunos universitarios principalmente los provenientes de la izquierda reformista- comenzaron a abandonar sus posicionamientos más antiperonistas y a cuestionar a las autoridades académicas y políticas del país ${ }^{204}$.

El diagnóstico anterior no era casual en un ensayista como Hernández Arregui, si se tiene en cuenta que él mismo provenía de sectores medios universitarios y que su esfuerzo intelectual buscaba cruzar al peronismo con el marxismo, mediante la construcción de una izquierda nacional que participara políticamente en el interior del movimiento conducido por Juan Domingo Perón ${ }^{205}$. Este tipo de apuestas no eran monopolizadas por el autor de $L a$ formación de la conciencia nacional. Desde una trayectoria político-intelectual diferente, uno de los pensadores más destacados del grupo gramsciano-guevarista-maoísta Pasado y presente sostenía reflexiones similares cuando abordaba a fines de los sesenta el viejo desencuentro entre universidad y peronismo ${ }^{206}$. Para Juan Carlos Portantiero, en esos años el movimiento universitario vivía una profunda autocrítica que todavía no concluía. La serie gabbiani de la editorial milanesa Il Sagiatore publicaría en enero de 1971 su trabajo Studenti e rivoluzione nell' América Latina. Dalla Reforma Universitaria del 1918 a Fidel Castro. E1 ensayo contenía un séptimo apartado denominado Estudiantes y populismo ${ }^{207}$. Era un escrito

participaron Rodolfo Ortega Peña, Eduardo Duhalde, Ricardo Carpani, Oscar Balestieri, entre otros. Las diferencias entre sus integrantes llevaron a su pronta disolución. Tarcus, H. (dir.), Diccionario biográfico de la izquierda argentina, Bs. As., Emecé, 2007, pp.306-307; Acha, O., Historia Crítica de la historiografia argentina. Vol. 1: las izquierdas en el siglo XX, Bs. As., Prometeo, 2009, p. 322; Entrevista a Oscar Balestieri, C.A.B.A., 02/12/2015.

203 Para fundamentar sus afirmaciones, Hernández Arregui presenta un conjunto de documentos de organizaciones estudiantiles y docentes que provenían de trayectorias ideológicas ajenas al peronismo. Hernández Arregui, J. J., Ob. cit., 2004, pp. 402-414.

${ }^{204}$ Ibídem, pp.358-365. La primera edición de La formación de la conciencia nacional fue en 1960, diez años antes de la segunda.

${ }^{205}$ Para reconstruir la trayectoria política-intelectual de Hernández Arregui, véase: Galasso, N., J.J. Hernández Arregui. Del peronismo al socialismo, Bs. As., Colihue, 2012; Terán, O., Nuestros años sesentas, Siglo XXI, 2013.

${ }^{206}$ Sobre Pasado y Presente puede consultarse: Burgos, R., Los gramscianos argentinos, Bs. As., Siglo XXI, 2005; Hilb, C., El político y el científico, Bs. As., Siglo XXI, 2012; Tortti, M. C., y Chama, M., "Los nudos político-intelectuales de una trayectoria. Reportaje a J. C. Portantiero", en Cuestiones de Sociología, No 3, FaHCE, UNLP, 2005.

${ }^{207}$ Portantiero, J. C., "Studenti e populismo", en Studenti e rivoluzione nell' América Latina. Dalla Reforma Universitaria del 1918 a Fidel Castro, Milán, Il Sagiatore, 1971, pp.151-171. El apartado fue traducido recientemente al español en Los trabajos y los días, N³, FTS, UNLP, 2012 y en Tortti, M. C. (dir.), La nueva izquierda argentina (1955-1976): socialismo, peronismo y revolución, Rosario, Prohistoria Ediciones, 2014. 
fechado el mes de mayo de 1969, que fue eliminado de la versión en español Estudiantes y política en América Latina de $1978^{208}$. Ese capítulo señalaba como un profundo error el enfrentamiento entre el movimiento estudiantil reformista y los primeros gobiernos peronistas. El conflicto con Perón había saldado la pelea entre padres e hijos al interior de la pequeña burguesía, cerrando brutalmente la disputa de las generaciones y eliminando las resonancias de la solidaridad obrero-estudiantil anunciada en el momento inicial de la Reforma del '18. De esta manera, recién en la autocrítica de los sesenta, muchos universitarios habrían comenzado a corregir esos errores con una mirada menos atenta a los intereses corporativo-democráticos, como la autonomía o el cogobierno universitario, y más pendiente de las clases sociales de la estructura capitalista dependiente, sin perder de vista la irrupción del proletariado industrial como nueva fuerza ascendente desde el 17 de octubre de 1945. El cuestionamiento no hacía más que volver a demandar la unión entre obreros y estudiantes o, dicho en términos gramscianos, una alianza entre proletarios e intelectuales ${ }^{209}$. El referente de Pasado y Presente tenía el anhelo de sepultar el viejo antiperonismo del Partido Socialista y Comunista. No por nada, discutía implícitamente con 20 años de movimiento estudiantil reformista (1943-1963), el libro de un antiguo militante del PC publicado en 1964 por la editorial Platina, que hablaba recurrentemente del "fascismo peronista" ${ }^{210}$.

No eran extrañas este tipo de afirmaciones en el campo político y cultural de aquellos años. Como apuntamos en el capítulo anterior, a lo largo de los sesenta, un conjunto de estudiantes, docentes e intelectuales procedentes de corrientes humanistas, reformistas y nacionalistas comenzaron a identificarse con el movimiento peronista y a entenderlo como una experiencia con potencialidades revolucionarias. El viraje seguía llamando la atención, todavía estaba fresca la memoria y se recordaba que buena parte de los activistas universitarios habían participado en la oposición que derivó en el golpe de Estado de 1955. Esto disparó un sinfín de preguntas y controversias, en un contexto muy distinto al de los años cuarenta y cincuenta: ¿Por qué muchos universitarios habían cambiado su opinión sobre el peronismo? ¿Cuál era el nuevo rol que pretendían asumir una vez superada la autocrítica y el distanciamiento? ¿Cómo podían construir un discurso para legitimar sus intenciones de transformar la universidad y el país? ¿Qué pensaban estos nuevos militantes peronistas sobre la Reforma de 1918 y la política universitaria de los primeros gobiernos de Perón? ¿Tenían un

\footnotetext{
${ }^{208}$ Portantiero, J. C., Estudiantes y política en América Latina, México, Siglo XXI, 1978.

${ }^{209}$ Celentano, A., y Tortti, M. C., "Estudiantes, izquierda y peronismo en la Argentina", en Tortti, M. C., Ob. cit., 2014, pp.211-232.

${ }^{210}$ Kleiner, B., 20 años de Movimiento Estudiantil Reformista (1943-63), Bs. As., Platina, 1964.
} 
nuevo proyecto para la universidad o sólo estaban interesados en los problemas de la revolución, el socialismo y la liberación?

Es imposible reconstruir todas las voces que hicieron alusión a estos temas. Pero para conocer cómo se debatieron en la UBA, no puede pasarse por alto la revista Antropología 3er. Mundo. Esta publicación vinculada a las Cátedras Nacionales (CN) de la Facultad de Filosofía y Letras logró convertirse en una referencia entre docentes, estudiantes y militantes de distintas casas de estudio. Un repaso crítico por sus notas y por sus discusiones con otras corrientes políticas permite revisar cómo abordaron la cuestión universitaria los sectores que se orientaron hacia el peronismo de izquierda a fines de los sesenta y principios de la década siguiente. Este asunto implicaba desentrañar el perfil de la universidad y su relación con la sociedad, la ciencia, los intelectuales y el movimiento estudiantil, en un contexto marcado por la proscripción del peronismo y la creciente inestabilidad del sistema político argentino ${ }^{211}$. La importancia de analizar dichas controversias desde las revistas de la época, radica en que las mismas estaban atravesadas por varias redes de sentidos y sus colaboradores mantenían múltiples lazos con otros agrupamientos del campo político, cultural y académico. En este sentido, tomamos a Antropología 3er. Mundo como punto de partida para reconstruir los debates sobre la universidad que entablaron grupos peronizados con otros actores de esos años; haciendo hincapié en la significación particular que otorgaron a la Reforma de 1918 y a la gestión universitaria del primer peronismo.

\section{II - UNA REVISTA DE CIENCIAS SOCIALES}

En la actualidad, el antiguo director de Antropología 3er. Mundo señala que todo comenzó a principios de los sesenta. Dos estudiantes de la carrera de Antropología que adherían a la Agrupación Nacional de Estudiantes (ANDE) se propusieron crear un ateneo o centro de estudios. De esa primera idea desistieron rápidamente, pero finalmente optaron por realizar una publicación vinculada a la política y su disciplina ${ }^{212}$. Más allá de la anécdota personal, a fines de la década ese proyecto se volvió realidad. Antropología 3er. Mundo fue publicada por primera vez en noviembre de 1968. Guillermo Gutiérrez dirigió los doce números que aparecieron hasta marzo de 1973. Las primeras ediciones llevaron el subtítulo de Revista de ciencias sociales. Esta autoproclamación no era menor y en cierta medida

\footnotetext{
${ }^{211}$ Para Beatriz Sarlo, la cuestión universitaria hace referencia al debate sobre el perfil de las casas de estudio y su relación con la sociedad, la cultura, la ciencia y los intelectuales. Por esta razón, tienen una faz académica y una ligada a posicionamientos políticos. Sarlo, B., La batalla de las ideas, Bs. As., Ariel, 2000, p. 91.

${ }_{212}$ Gutiérrez, G., "Antropología 3er. Mundo. Cuatro décadas, algunas reflexiones sobre el contexto de origen”, en Antropología 3er. Mundo, Edición facsimilar FFyL, UBA, 2009, p. 11.
} 
sintetizaba la propuesta inicial de la publicación de situar su labor desde el ambiente intelectual. Pero al igual que otras experiencias culturales de la nueva izquierda, enmarcó esa tarea dentro de proyectos políticos más amplios que hablaban de peronismo, socialismo y revolución. En este punto, tampoco era casual que el editorial del primer ejemplar citara implícitamente el programa "10 de mayo" de la CGT de los Argentinos (CGTA) que había escrito Rodolfo Walsh ${ }^{213}$. Esa plataforma de la central de Ongaro concebía a los intelectuales como una capa intermedia que debía "superar sus dudas" y elegir entre las clases que "verdaderamente gravitaban" sobre el destino de la sociedad. La cultura no era entendida como un ámbito neutral y la praxis de los cientistas sociales no podía permanecer ajena frente a dos problemáticas que acapararon buena parte del discurso político de los sesenta: la explotación de clase y la dependencia. Desde su primer ejemplar, la revista tejía un relato donde la antropología era elegida como la disciplina más abarcadora de lo social y el tercer mundo como un lugar de pertenencia ante la política de coexistencia del imperialismo norteamericano y soviético ${ }^{214}$.

El segundo número de Antropología 3er. Mundo apareció en mayo de 1969, un año signado por fuertes conflictividades sociales y políticas, especialmente por los sucesos que ocurrieron a fin de mes en la ciudad de Córdoba. En esa edición, Roberto Carri publicó la última parte de "El formalismo en las ciencias sociales". La nota era una expresión más concreta y sistemática de la propuesta político-intelectual que había comenzado a esbozarse en el editorial del ejemplar anterior. El autor de Isidro Velázquez. Formas prerrevolucionarias de la violencia creía que la única "alternativa verdadera" para un sociólogo consistía en producir científicamente desde la propia realidad de los sectores subalternos. De esta manera, una teoría crítica de las desigualdades sociales y del neocolonialismo sólo podía realizarse desde el peronismo, porque era un movimiento que expresaba la identidad política y los anhelos transformadores de las clases populares $\operatorname{argentinas}^{215}$. Este tipo de discurso intentaba conectar el anhelo de un nuevo proyecto académico con la necesidad de una militancia política concreta. El peronismo se había convertido en una preocupación político-intelectual de las ciencias sociales desde que Gino Germani lo convirtió en el objeto de estudio de la naciente carrera de Sociología ${ }^{216}$. Sin embargo, Antropología 3er. Mundo fue mucho más allá. Lo novedoso de su apuesta no era

\footnotetext{
213 "10 de mayo: mensaje a los trabajadores y al pueblo argentino", Semanario CGT, № 1, 1 de mayo 1968.

214 “Antropología, Antropologías”, en Antropología 3er. Mundo, № 1, noviembre de 1968.

${ }^{215}$ Carri, R., "El formalismo en las ciencias sociales (2da. Parte)", en Antropología 3er. Mundo, № 2, mayo de 1969. Más tarde, Carri recopiló sus trabajos de Antropología 3er. Mundo y Envido en el libro Poder imperialista y liberación nacional, Bs. As., Efece Ediciones, 1973.

${ }^{216}$ Neiburg, F., Los intelectuales y la invención del peronismo, Bs. As., Alianza Editorial, 1998.
} 
esa vieja reconsideración positiva del movimiento que ya venían realizando otros núcleos intelectuales de la nueva izquierda, sino la empresa de una ciencia crítica que reclamaba al peronismo concreto como espacio necesario de producción de conocimiento ${ }^{217}$.

El enfoque propuesto en los primeros ejemplares permitió la difusión de un conjunto de análisis político-académicos sobre temáticas diversas: la relación ciencia y política, las controversias sobre peronismo y universidad, el debate acerca de la capacidad explicativa de las teorías marxistas en las sociedades de la periferia, la reflexión sobre las vertientes del pensamiento nacional, la crítica al estructuralismo, el desarrollismo y el cientificismo, y otras problemáticas del mismo estilo. Artículos como "La antropología estructural de Lévi-Strauss y el Tercer Mundo" de Amelia Podetti ( $\left.{ }^{\mathrm{o}} 2\right)$, "El movimiento nacional y la universidad" de Gonzalo Cárdenas ( $N^{o} 3$ ), "La tercera posición justicialista y el marxismo" de Norberto Wilner ( $\mathrm{N}^{\mathrm{o}} 4$ ), “Pensamiento teórico y político" de Justino O’Farrell ( $\mathrm{N}^{\mathrm{o}}$ 5), "Notas sobre el pensamiento nacional” de Gunnar Olsson ( $\mathrm{N}^{\circ}$ 5), "La sociología nacional, las sociologías y la sociología" de Enrique Pecoraro ( $\mathrm{N}^{\mathrm{0}}$ 5), "Notas sobre la polémica con el marxismo" de Alcira Argumedo ( $\left.\mathrm{N}^{\mathrm{o}} 6\right)$, "Poder y dependencia" de Carri ( $\mathrm{N}^{\mathrm{o}}$ 6), eran sintomáticos al respecto. Este tipo de escritos intentaban delimitar un campo de estudio atravesado por la cuestión política e intelectual, mediante una concepción politizada del quehacer universitario que articulara la especificidad de las prácticas culturales con una intervención política más abarcadora ${ }^{218}$.

El nombre de los firmantes en las notas descriptas tampoco era un tema menor. A principios de los setenta, apareció un número doble y especial de Antropología 3er. Mundo que llevaba como título "Cátedras Nacionales. Aportes para una ciencia popular en la argentina" y la portada estaba acompañada por una imagen que exhibía una bandera cuya consigna rezaba: "Facultad tomada por los profesores peronistas". El mismo Horacio González aclaraba en su nota "Estrategia, ideología y análisis institucional”, que aprovechaba esta publicación especial para ajustar la extensión de su texto ya que la discusiones políticas que tenían lugar en su "práctico" de Problemas de Sistemática exigían escritos que ahorraran largas fundamentaciones y la exposición detallada de supuestos ${ }^{219}$. Pero más allá de lo anecdótico, la quinta y sexta entrega de Antropología 3er. Mundo manifestaba explícitamente el espacio que impulsaba la revista y la pertenencia de sus principales referentes: los mismos

\footnotetext{
${ }^{217}$ Rubinich, L., "La modernización cultural y la irrupción de la sociología", en James, D. (comp.), Violencia, proscripción y autoritarismo (1944-1976), Bs. As., Sudamericana, 2007, pp. 266-267.

${ }_{218}$ Dip, N., "En busca de un relato para la universidad. Reminiscencias reformistas y peronistas en Antropología 3er. Mundo", en E L@tina. Revista Electrónica de Estudios Latinoamericanos, № 56, 2016.

${ }^{219}$ González, H., "Estrategia, Ideología, análisis institucional", en Antropología 3er. Mundo, ํㅜ 5 y 6, 1970, p.113. Como vimos en el primer capítulo, Problemas de Sistemática era una materia optativa de la carrera de Sociología de la Facultad de Filosofía y Letras. Estaba relacionada a Sociología Sistemática, asignatura obligatoria del plan de estudio que encabezaba O'Farrell.
} 
formaban parte de las CN de la carrera de Sociología de la Facultad de Filosofía y Letras.

Como señalamos en el capítulo anterior, esta experiencia fue posible por el proceso de renuncias y cesantías que produjeron "los bastones largos" de Onganía en la casa de estudio porteña a mediados de los sesenta. Un par de docentes que habían sido designados por la intervención y un grupo de graduados recientes aprovecharon el espacio vacante y terminaron haciéndose cargo de un conjunto de materias obligatorias y optativas. La mayoría provenían de ámbitos católicos y de izquierda no peronistas que habían sufrido fuertes trasformaciones ideológicas a principios de esa década. Esta formación heterogénea previa de los integrantes de las $\mathrm{CN}$ explica en buena medida la diversidad de categorías teóricas y políticas que pusieron en juego en Antropología 3er. Mundo. Las citas de sus artículos hacían referencia al humanismo, el marxismo occidental, la teología de liberación, la teoría de la dependencia, el pensamiento nacional, el peronismo y a los estudiosos de la descolonización del tercer mundo. Desde Sartre, Gramsci y la Escuela de Frankfurt, hasta Scalabrini Ortiz, Jauretche, Hernández Arregui, Perón, Gunder Frank, Frantz Fanon y Mao Tse Tung. Este corpus bibliográfico, como la misma procedencia de los docentes de las CN, llevó a Antropología 3er. Mundo a travesar varias redes de sentidos y a mantener múltiples lazos con otros agrupamientos culturales, políticos e intelectuales ${ }^{220}$. Un ejemplo de este último punto fue el lugar que la revista otorgó a colaboraciones externas de intelectuales, sindicalistas, políticos, cineastas y militantes cristianos que no formaban parte del staff permanente, como "Ideología, ciencia y estrategia" de Conrado Eggers Lan ( $\mathrm{N}^{\mathrm{o}}$ 2), "El movimiento nacional y el movimiento obrero" de Julio Guillán ( $\left.\mathrm{N}^{\mathrm{o}} 4\right)$, "Negociación, conciliación y elección" de Julián Licastro ( $\mathrm{N}^{\mathrm{o}} 8$ ), "62 modelo para desarmar" de Octavio Getino ( $\left.\mathrm{N}^{\mathrm{o}} 8\right)$, "La Iglesia del Tercer Mundo" de Norberto Habegger ( $\mathrm{N}^{\circ}$ 9), entre otros.

\section{III - Primeros Debates SOBRe la CUESTIÓN UNIVERSITARIA}

Arturo Jauretche publicó El medio pelo en la sociedad argentina en noviembre de 1966. El libro no pasó desapercibido y rápidamente aparecieron sucesivas reediciones en diciembre de ese mismo año y en enero de 1967. El carácter de "best seller" que adquirió al poco tiempo no debería llamar la atención. El trabajo del antiguo dirigente de la Fuerza de Orientación Radical de la Joven Argentina (FORJA) tenía como subtítulo Apuntes para una sociología nacional y buena parte de su contenido aludía a la conflictiva relación de la clase

\footnotetext{
${ }^{220}$ Barletta, A. M. y Lenci, M. L., "Politización de las Ciencias Sociales en la Argentina. Incidencia de la revista Antropología 3er. Mundo 1968-1973”, en Cuadernos del CISH, № 8, FaHCE, UNLP, 2001, p. 178.
} 
media con el peronismo 221 . Esta problemática político-cultural no era nueva y venía siendo discutida en años anteriores. A fines de los cincuenta, fue apareciendo en la izquierda argentina una serie de relatos sobre la controversia pequeña burguesía - peronismo. Estos discursos no pasaban por alto la importancia pública que adquirió aquel sector social desde su participación en el frente antiperonista que derrocó al segundo gobierno de Perón. Viejos intelectuales de izquierda que ya se habían acercado al primer peronismo, como Rodolfo Puiggrós y Hernández Arregui, y núcleos jóvenes que se escindieron o diferenciaban del Partido Socialista y Comunista, como Juan José Sebreli y Portantiero, criticaron a su propia clase por haber incomprendido y combatido la experiencia política de los trabajadores. Como señala Carlos Altamirano, a partir de sus ensayos, libros y reflexiones se fue conformando una literatura socio-psicológica sobre la pequeña burguesía que demandaba un camino de reconciliación con el proletariado peronista ${ }^{222}$.

En este contexto político-intelectual, no resultan extrañas ciertas orientaciones temáticas que adquirió Antropología 3er. Mundo al poco tiempo de aparecer. Su tercer número fue publicado en noviembre de 1969. La tapa contenía una ilustración de Juan Manuel de Rosas y el título giraba "En torno a las posiciones nacionales". Mientras el cuarto ejemplar de la revista estaba fechado en diciembre de 1970 y en su portada aparecía dibujado un inca que reclamaba sus tierras a los gamonales, debajo de las palabras de dependencia, tercera posición y movimiento obrero. La presentación y las temáticas eran similares a las propuestas de las ediciones anteriores. Sin embargo, en ambos números aparecieron un par de notas firmadas por dos de los principales referentes de la publicación que trataban una problemática que no había sido abordada con suficiente centralidad. Los títulos de los artículos eran sugestivos y el contenido pretendía disparar una serie de discusiones sobre viejos antagonistas: el peronismo, la universidad, los intelectuales y el movimiento estudiantil.

El primero era "El movimiento nacional y la universidad" y estaba firmado por Cárdenas. A la luz de los levantamientos populares ocurridos en Córdoba y Rosario, el entonces director del Instituto de Sociología de la Facultad de Filosofía y Letras, establecía un diagnóstico tajante: la salida revolucionaria en la Argentina dependía del peronismo y sólo podía realizarse con la integración de las capas medias y los trabajadores a una "única clase popular" 223 . Para Cárdenas, el problema de la dependencia y el cambio social requería una

\footnotetext{
${ }^{221}$ Jauretche, A., El medio pelo en la sociedad Argentina, Bs. As., Corregidor, 2012.

${ }^{222}$ Altamirano, C., Peronismo y cultura de izquierda, Bs. As., Siglo XXI, 2011, p. 107.

${ }^{223}$ Cárdenas, G., "El movimiento nacional y la universidad", en Antropología 3er. Mundo, № 3, noviembre 1969, p. 54.
} 
reflexión sobre uno de los desencuentros sociales más revisitados en esos años. Por esta razón, deducía su diagnóstico de una interpretación historiográfica del itinerario que siguieron el peronismo y los estudiantes, a los que consideraba como la "vanguardia ideológica" de los sectores medios. El análisis no contaba con una pesquisa profunda del enfrentamiento que habían mantenido los universitarios con los primeros gobiernos peronistas. La explicación propuesta no iba más allá de los "aparatos de colonización cultural" que supuestamente acentuaban su separación de los trabajadores. Sin embargo, establecía una serie de reflexiones sobre la incipiente peronización del estudiantado que era sintomática y se inscribía en las lecturas que realizaban algunos núcleos intelectuales de la nueva izquierda. El antiguo militante de Democracia Cristiana (DC) describía dos formas de democratización de la universidad para ilustrar esa trayectoria compleja. A partir del 17 de octubre de 1945, la política de los primeros gobiernos peronistas intentó abrir la universidad a los sectores populares “desde el exterior". El golpe de Estado de la "Revolución Libertadora" frustró esta posibilidad, pero a fines de los cincuenta -y sobre todo con el Plan de Lucha de la CGT de 1964-, una lenta nacionalización de estudiantes y jóvenes docentes reformistas, humanistas, ateneístas e integralistas revaloriza al peronismo, cuestiona a los "maestros" que habían ingresado a la docencia mediante concursos con trabas proscriptivas y comienza a generar las condiciones para abrir la universidad "desde el interior",224.

La intervención universitaria del '66, la aparición de la CGTA y la movilización estudiantil durante el Cordobazo no habrían hecho más que profundizar el proceso descripto anteriormente. No obstante, el diagnóstico de Cárdenas era cauteloso. A fines de los sesenta, todavía señalaba que la existencia de tendencias nacionales en el estudiantado manifestaba una lenta transición de militantes hacia el peronismo y que la situación aún evidenciaba una falta de conducción política unitaria ${ }^{225}$. Esta advertencia reafirmaba un diagnóstico concluyente: si se pretendía integrar a los sectores medios ilustrados al peronismo, había que partir de las especificidades organizativas e ideológicas del mundo universitario y abandonar

\footnotetext{
${ }^{224}$ En este punto, el artículo de Cárdenas señalaba dos cuestiones. Una eran las proscripciones establecidas en el artículo 37 del decreto-ley 6.403, que sancionó el general Pedro Eugenio Aramburu el 23 de diciembre de 1955. Esta normativa universitaria prohibía presentarse a concurso a los que habían manifestado adhesiones al peronismo gobernante. La otra era la idea de que la nacionalización de los universitarios no implicaba necesariamente una peronización. Había sectores que podían abandonar el antiperonismo y hablar de liberación nacional, pero eso no significaba que se hicieran peronistas. Ibídem, p.58.

${ }^{225}$ A pesar de estas falencias, Cárdenas consideraba que los dos pilares de la agitación estudiantil eran las agrupaciones nacionales como UNE y las organizaciones marxistas independientes del PC. Ibídem, pp.62-63. En este tema, estaba haciendo referencia a los grupos estudiantiles que tuvieron mayor visibilidad en las protestas contra la dictadura junto a la CGTA. Como mostramos en el capítulo anterior, aparte de UNE también estaban el FEN y la FUA. A fines de los sesenta, estos últimos discutieron la forma de llevar adelante la unificación del movimiento estudiantil para superar su fragmentación, pero sus intentos no tuvieron correlato en la práctica.
} 
un "doble error" de construcción política. El primero consistía en persistir en la línea metodológica de la época de la Resistencia Peronista. La misma consideraba que los estudiantes debían abandonar la vida universitaria para sumarse a las organizaciones sindicales. Y el segundo era una reformulación de esa renuncia pero evocada desde una "izquierda castrista" que reivindicaba una "línea guerrillera" por fuera de las casas de estudio.

El problema que visualizaba Cárdenas era que no bastaba con repetir que los estudiantes habían sido "gorilas", sino que lo relevante era reconocer el peso específico de este sector social y su importancia a la hora de definir los hechos políticos y sociales del país $^{226}$. Aunque no lo afirmara explícitamente, en este punto estaba haciendo una clara crítica a la metodología política que llevaron adelante los grupos estudiantiles peronistas de la primera mitad de los sesenta. Como vimos en el capítulo anterior, en aquel momento existió por unos años una Juventud Universitaria Peronista (JUP) que coordinaba a los ANDE de cada facultad. La misma se desatendió de una militancia específica en la universidad debido a que su principal objetivo era "captar" estudiantes para insertarlos en las actividades del sindicalismo y de las agrupaciones políticas del peronismo proscripto.

La segunda nota de Antropología 3er. Mundo que abordaba el tópico peronismouniversidad era "Pensamiento nacional y política". El artículo llevaba la firma de Gutiérrez y funcionaba como editorial del cuarto número. El mismo también contaba con intervenciones de Carri, Wilner, Guillán y Carlos Fernández Pardo. El trabajo del director de la revista no era exactamente igual al publicado por Cárdenas en la entrega anterior. Hacía mayor hincapié en una reflexión histórica sobre el proceso universitario argentino y bosquejaba cuatro etapas de su desarrollo: la Reforma de 1918, los gobiernos peronistas, la "Revolución Libertadora" y el período abierto con el golpe de Estado de 1966. Lo destacable no era la previsible denuncia del papel opositor que jugó la Federación Universitaria Argentina (FUA) frente a los gobiernos de Hipólito Yrigoyen y Perón, sino las interpretaciones sobre el derrotero de la Reforma y la política del primer peronismo ${ }^{227}$.

La primera no era negada directamente y se la concebía como una consecuencia del ascenso al poder del radicalismo. Pero se la cuestionaba por haber perdido la posibilidad de elaborar un "pensamiento argentino y americano" en los claustros y transformarse en una simple reivindicación de autonomía que sólo atendía privilegios de camarillas universitarias $^{228}$. Para Gutiérrez, recién los primeros gobiernos de Perón van a efectivizar la

\footnotetext{
${ }^{226}$ Ibídem, p. 61.

${ }^{227}$ Gutiérrez, G., "Pensamiento nacional y política", en Antropología 3er. Mundo, № 4, septiembre 1970, p. 3.

${ }^{228}$ Ibídem, pp. 3-4.
} 
democratización social de las casas de estudio con la "ley de supresión de aranceles", la jerarquización de la situación docente, la ampliación de presupuesto, de la matrícula estudiantil y el fortalecimiento de la enseñanza técnica superior. No debe perderse de vista que esta lectura contenía referencias al documento Peronismo y Universidad que editó la agrupación estudiantil FANDEP en agosto de 1967 y del escrito La Juventud y los trabajadores de Perón, publicado tres años después por Ediciones Lealtad ${ }^{229}$.

Al igual que el trabajo de Cárdenas, las reflexiones del director de Antropología 3er. Mundo solo hacían énfasis en una dimensión de la política universitaria del primer peronismo: la vinculada a la gratuidad y a la incorporación de clases sociales que nunca habían transitado la educación superior. De todas maneras, lo más relevante de su diagnóstico eran las tensiones que afloraban cuando intentaba explicar las consecuencias de la nacionalización de sectores estudiantiles e intelectuales provenientes del reformismo y el socialcristianismo. Aunque resaltaba que la intervención de 1966 había sido un catalizador de dicho proceso, sostenía que el mismo ya venía manifestándose en años anteriores, cuando comenzaron a escucharse las críticas al "gorilismo", al "cientificismo" y al "limitacionismo" 230 . Lo paradójico del análisis era que proponía al mismo tiempo una doble negación y una especificidad. Para poder dejar a la política como único desempeño válido, los estudiantes y pensadores de tendencia nacional debían llevar adelante un doble "acto de violencia" consigo mismos al romper sus expectativas profesionales y negarse como intelectuales. Sin embargo, esa superación supuestamente les permitiría cierta especialización en la tarea política ya que el movimiento nacional debía enfrentar al imperialismo en "todos los terrenos", principalmente en ambientes culturales, como la universidad, los circuitos artísticos y los medios de comunicación. Desde este razonamiento, para Gutiérrez no debería haber intelectuales como actores escindidos del conjunto social, pero sí militancias en terrenos específicos ${ }^{231}$.

La discusión sobre política y universidad del cuarto número de Antropología 3er. Mundo no se reducía a la intervención de su director. Esa entrega de la revista cerraba con una sección titulada "Documentos" que contenía el Manifiesto de F.O.R.J.A a los estudiantes de la Universidad de Buenos Aires, cuya publicación estaba fechada en junio de $1943^{232}$. La corriente disidente del radicalismo dirigida por Jauretche y Darío Alessandro entendía que el

\footnotetext{
${ }^{229}$ Ibídem, p. 11.

${ }^{230}$ Ibídem, p. 7.

${ }^{231}$ Ibídem, p. 9.

${ }^{232}$ FORJA se fundó en junio de 1935 en Buenos Aires como producto de una tendencia de la juventud del partido radical que había intentado combatir la influencia del alvearismo en la UCR. Entre sus más destacados integrantes se encontraban Jauretche, Darío Alessandro, Homero Manzi, Luis Dellepiane y Raúl Scalabrini Ortiz. "FORJA y la Universidad", en Antropología 3er. Mundo, No 4, septiembre 1970, p. 59. El documento aclaraba que estaba en consonancia con la declaración de la Junta Nacional de FORJA, realizada el 29 de junio de 1943.
} 
golpe de Estado del día 4 de ese mismo mes iniciaba la "crisis del régimen antinacional" que venían denunciando desde el derrocamiento del segundo gobierno de Yrigoyen. En dicho contexto, FORJA criticaba a los reformistas por haber "malogrado" los planteos iniciales de la Reforma del '18 y por haberla reducido a una serie de demandas meramente académicas. A pesar de todo, el cuestionamiento no era una negación de la misma, ya que el manifiesto hacía un llamado a recuperar lo que consideraba su "conquista básica y principio rector": la participación de los estudiantes en la política de la universidad. El accionar de ese sector era entendido como una correa de trasmisión que permitiría articular la problemática universitaria con la cuestión social, nacional y americana. Por esta razón, una "autonomía comprometida" sólo sería posible si se rescataba su "actitud crítica" en la cátedra y en los cuerpos directivos de la universidad ${ }^{233}$.

A partir de estas afirmaciones, el documento de FORJA proponía transformar la orientación y los métodos de enseñanza en las casas de estudio. A su entender, la universidad debía desterrar la "estrategia del lucro personal" y dotarse de una "misión de servicio" con el país y el continente latinoamericano. Por eso, hacía un llamado a la construcción de una metodología de enseñanza basada en equipos de estudio y de trabajo que consideraran al "país entero" como su espacio pedagógico. La educación experimental en instituciones del Estado, establecimientos industriales y zonas rurales haría efectiva la anhelada extensión universitaria y permitiría concentrar a los estudiantes y profesores en un conjunto de tareas sociales diversas que trascenderían las pequeñas dimensiones edilicias de la facultades: comisiones de estudio, censos, controles, investigaciones en agronomía y minería, asistencia social, asesoramiento técnico, formación de trabajadores, enseñanza de adultos, mejoramiento sanitario, creación de grupos artísticos, organización del turismo escolar y obrero, atención jurídica en el territorio, difusión cultural, clasificación de bibliotecas, archivos y materiales históricos, entra otras. Para FORJA, este tipo de actividades fortalecería la vocación de servicio de los estudiantes y su remuneración permitiría alejar de los claustros a los que hacen del estudio el pretexto de sus ocios y fomentar el ingreso a la universidad de aquellos jóvenes con dificultades económicas. La idea era orientar a la enseñanza superior hacia la investigación, el trabajo por equipos, la terea social y el contacto con la realidad ${ }^{234}$.

\section{ENTRE LA REFORMA Y EL PRIMER PERONISMO}

El documento de FORJA como las notas de Cárdenas y Gutiérrez comentadas

\footnotetext{
${ }^{233}$ Ibídem, p. 65.

${ }^{234}$ Ibídem, p. 68.
} 
anteriormente, mostraban que Antropología 3er. Mundo intentaba afianzar un espacio de debate sobre los problemas e interrogantes que traía aparejada la peronización de estudiantes, docentes e intelectuales ¿Por qué tantos universitarios habían cambiado su opinión sobre el peronismo? ¿Cuál era el nuevo rol y los discursos que pretendían asumir para superar el distanciamiento de los años cuarenta y cincuenta? Estas preguntas y el desafío asumido tenían múltiples aristas y obligaban a ajustar cuentas con el pasado reciente. Como sostiene Raymond Williams en su clásico libro Marxismo y literatura, todos los actores sociales que pretenden justificar nuevas prácticas sociales y definir sus identificaciones culturales necesitan una versión intencionalmente construida de los sucesos históricos precedentes, donde ciertos significados sean acentuados y otros rechazados o excluidos ${ }^{235}$. Lo interesante de Antropología 3er. Mundo fue que para legitimar la presencia del peronismo en la universidad y zanjar el viejo desencuentro con los sectores medios, llevó adelante una interpretación selectiva de la Reforma del '18 y de la política universitaria de Perón.

Como señalamos en los párrafos precedentes, esta última era revalorizada, sobre todo, por establecer la gratuidad de la enseñanza superior y fomentar el acceso de clases populares que nunca habían transitado la universidad. La democratización social de las casas de estudio mediante la supresión de aranceles y el ingreso irrestricto, si bien fue una demanda que sostuvieron algunos sectores del movimiento reformista, recién se hizo efectiva en los primeros gobiernos justicialistas ${ }^{236}$. No obstante, había algo que esa experiencia no podía ofrecer y era central en un peronismo de izquierda que reivindicaba el protagonismo político de la juventud: la intervención de los estudiantes en la dirección de la educación superior. Las dos leyes universitarias del primer peronismo establecieron una subordinación de las facultades al poder ejecutivo y una escasa influencia política del estudiantado en sus órganos de gobierno. La llamada Ley Guardo (13.031), promulgada el 9 de octubre de 1947, prohibía

\footnotetext{
${ }^{235}$ Williams, R., Marxismo y literatura, Bs. As., Las Cuarenta, 2009, p.153.

${ }^{236}$ El Primer Congreso Nacional de Estudiantes de la FUA realizado en medio de las protestas que dieron origen a la Reforma en 1918, discutió entre sus demandas la gratuidad total de la enseñanza superior, pero no llegó aprobarla. En los años siguientes, hasta los mismos centros de estudiantes enfrentaron el levantamiento de aranceles y de exámenes de ingreso, debido a que era un poderoso mecanismo para controlar el acceso al título profesional. Aunque, no está de más aclarar, que los sectores más politizados del reformismo fueron incorporando y fortaleciendo esa demanda con el correr del tiempo, como lo manifestaba el acta fundacional de la Unión Latinoamericana que firmaron José Ingenieros, Julio V. González, Gabriel Del Mazo y Deodoro Roca el 21 de marzo de 1925. Por otra parte, los gobiernos de Perón también vacilaron en este camino. La ley universitaria de 1947 y la Constitución de 1949 garantizaban un sistema de becas, pero ninguna consagraba la gratuidad de los estudios superiores y el ingreso irrestricto. La supresión de aranceles recién se hizo efectiva mediante el decreto 4.493 que dictó Perón en 1952 y luego ratificó el poder legislativo en el artículo 71 de la ley universitaria 14.297 de 1954. A su vez, en 1953 habían sido eliminados los exámenes de ingreso. Este conjunto de políticas permitieron estimular un crecimiento exponencial de la matrícula y ampliar la base social del estudiantado, aunque nunca pudieron solucionarse las tasas extremadamente altas de deserción. Sobre estos temas puede consultarse Nota ampliatoria "III - La universidad peronista", pp. 221-224.
} 
la actividad política y reducía la representación estudiantil en el consejo directivo a un delegado sin poder de voto, el cual debía ser elegido mediante un sorteo entre los diez alumnos de mejores calificaciones del último año. Mientras el segundo ordenamiento legal fue aprobado el 11 de enero de 1954, bajo la gestión de Armando Méndez San Martín como ministro de Educación, y continuaba otorgando un papel secundario a los estudiantes. Para la Ley 14.297, estos últimos podían contar con un representante en la dirección de las facultades, con capacidad de voto en cuestiones que afectaran los intereses del alumnado, pero necesitaba provenir de los últimos tres años de la carrera y formar parte de una entidad gremial reconocida: la Confederación General Universitaria $(\mathrm{CGU})^{237}$.

Frente a este panorama, Antropología 3er. Mundo optó por repasar la historia de la universidad y recurrir al documento de FORJA para rescatar aspectos positivos de la Reforma. Aunque las notas de la revista cuestionaron fuertemente el papel del reformismo en el derrocamiento de Yrigoyen y Perón, en sus páginas parecía rondar el espíritu del Manifiesto Liminar y de Deodoro Roca cuando argumentaban que la participación política del estudiantado legitimaba una presencia crítica en las universidades y permitía articular la problemática académica con confrontaciones sociales más amplias ${ }^{238}$. En el fondo, a Antropología 3er. Mundo le era imperioso buscar un nuevo relato para la universidad que dejara atrás el viejo enfrentamiento entre libros y alpargatas. Por esta razón, entendía que el camino más apropiado no era desatender la situación particular de los universitarios o

\footnotetext{
${ }^{237}$ Mignone, E., Ob. cit., 1985, pp. 25-35; Buchbinder, P., Historia de las universidades argentinas, Bs. As., Sudamericana, 2010, pp. 144-168.

${ }^{238}$ Los reclamos más importantes de la Reforma quedaron plasmados en el Manifiesto Liminar redactado por Deodoro Roca, el cual se publicó el 21 de junio de 1918 en la Gaceta de la Federación Universitaria de Córdoba (FUC) y en el Primer Congreso Nacional de Estudiantes de la FUA celebrado entre el 20 y 31 de julio de ese mismo año. Las dos demandas centrales del movimiento reformista eran la participación estudiantil en los órganos de gobierno y la libertad de cátedra. El Manifiesto Liminar llamaba a una nueva hora americana encabezada por las jóvenes generaciones y proclamaba la ruptura de la última cadena de dominación monárquica y monástica que pervivía en pleno siglo XX. Pero en lo estrictamente universitario, sus propuestas eran muy claras y acotadas. Para la FUC, sólo era posible crear una institución democrática, científica y moderna, si la soberanía de la universidad radicaba principalmente en los estudiantes. En la actualidad, muchos otorgan a la Reforma principios y consignas que no estaban entre las reivindicaciones más importantes de 1918, como la autonomía y el ingreso gratuito e irrestricto a la enseñanza superior. La primera es llamativa si se tiene en cuenta que en el Manifiesto Liminar ni siquiera aparecía la palabra. De todas maneras, esto no implica negar que luego de los sucesos de Córdoba el movimiento reformista amplió su repertorio académico y político-ideológico. Por otra parte, el congreso de la FUA de 1918 también manifestó una controversia sobre política y universidad que marcó los orígenes de la Reforma. El movimiento estudiantil estaba atravesado por dos posiciones que disputaban su hegemonía. La primera resultó mayoritaria y la encabezaba el presidente electo de la FUA. Osvaldo Loudet representaba una corriente apoliticista que pretendía mantenerse al margen de los partidos y de las problemáticas socio-políticas externas. El otro sector agrupaba a dirigentes que tendrían una larga trayectoria política, como Gabriel Del Mazo, Julio V. González y Alejandro Korn. Para esta postura, era inconcebible separar a la Reforma de trasformaciones sociales más amplias. En los sucesos de 1918, terminaron en inferioridad, pero a la larga su lectura tuvo una influencia mayor en Argentina y el resto de Latinoamérica. Puede decirse que FORJA fue una heredera de estos últimos posicionamientos. Véase: Notas ampliatorias "I- La Reforma Universitaria de 1918”, pp. 215-219; “II- EI ideario reformista: esa tensión irresoluble entre universidad y política", pp. 219-221.
} 
desconocer tácticas de alianza efectivas entre trabajadores y sectores medios. Seguir esta opción habría implicado negar su propio papel político en su anhelada construcción estratégica del socialismo nacional. En este punto, no debe olvidarse que la mayoría de los integrantes de la publicación provenía de círculos de clase media no peronistas. Por eso, al revalorizar el papel político-académico de los universitarios estaban pensando su propio presente y futuro dentro del movimiento peronista.

De todas maneras, también es necesario aclarar que este tipo de cuestiones y problemáticas no eran nuevas en esos años. La pregunta sobre cómo y de qué manera articular la estrategia y la táctica, lo general y lo particular, el peronismo y los estudiantes, la revolución y la universidad, acuciaba a distintas experiencias políticas y culturales desde fines de los cincuenta y principios de los sesenta. Un caso ejemplar con puntos en común con Antropología 3er. Mundo fue el Movimiento de Liberación Nacional; la fórmula política que encararon los hermanos Viñas y otros ex - integrantes de la revista Contorno para dejar atrás el distanciamiento con el peronismo, la fallida experiencia en el gobierno de Frondizi y sentar las bases de un partido revolucionario en la Argentina ${ }^{239}$. En 1964, el MLN editó un pequeño libro titulado Estrategia en la universidad con la intención de orientar su militancia en ese ámbito $^{240}$. Su diagnóstico revelaba una actitud ambivalente hacia las demandas reformistas y las peticiones gremiales de los estudiantes. La necesidad de crear una organización revolucionaria dejaba en segundo plano las reivindicaciones sobre la autonomía, el gobierno tripartito, la política estudiantil, la libertad de cátedra y el presupuesto. Lo principal era la práctica política partidaria en pos de trastocar la estructura de clases del capitalismo dependiente argentino. Esto terminaría beneficiando a la universidad porque su verdadera democratización llegaría después de la revolución y no con la concreción de demandas parciales del movimiento estudiantil. Sin embargo, esta primera lectura se complejizaba cuando en la última parte del informe el MLN reconocía que para acercar a los estudiantes, docentes, intelectuales y profesionales al partido no quedaba otro camino que reconocer sus exigencias particulares. Esto implicaba construir tácticas de alianzas con otras agrupaciones

\footnotetext{
${ }^{239}$ El MALENA o MLN surgió a principios de los sesenta. Era un partido predominantemente de clase media, dirigido por intelectuales que se habían involucrado personalmente en el gobierno de Frondizi: Neó Jitrik fue secretario del Senado; Ramón Alcalde dirigió el Ministerio de Educación en Santa Fe; Susana Fiorito participó en la Convención del Partido Intransigente e Ismael Viñas ocupó la Subsecretaría de Cultura. Pacheco, J., Nacional y popular, Bs. As., Ediciones R y R, 2012, p. 59.

${ }^{240}$ La mayor parte del libro fue redactado por Ramón Alcalde y su capítulo VI, "El quehacer revolucionario en la universidad", estuvo a cargo de una comisión integrada por Ismael Viñas, Ricardo Scaricabarozzi, Juan Ritvo, León Rozitchner, Ernesto Poper y Haydée Gurassa. El frente universitario del MLN era la Agrupación Universitaria Liberación (AUL). Tenía presencia en Córdoba, Rosario, Santa Fe y en Capital Federal, especialmente en las facultades de Ciencias Exactas, Arquitectura y Filosofía y Letras. Ibídem, p.153; Alcalde, R., Estrategia en la Universidad, Bs. As., Ediciones del MLN, 1964.
} 
universitarias y trabajar políticamente con las especificidades de dicho ámbito ${ }^{241}$.

La agrupación de los antiguos contornistas no asumió una identidad peronista como sí lo hizo posteriormente Antropología 3er. Mundo. Pero su necesidad de articular las demandas académicas y políticas también estuvo relacionada con una actitud revisionista respecto de la Reforma y de la universidad del primer peronismo. En este punto, había más de una coincidencia. Otrora opositores estudiantiles en la década de Perón, a quien acusaban de autoritario y antidemocrático, ahora los integrantes del MLN llegaban a afirmar que la mayor expansión social de la enseñanza universitaria se produjo en esos años, con la supresión de aranceles, la creación de la "universidad tecnológica" y el otorgamiento de licencias para estudiantes trabajadores. Para ellos, esto había sido desconocido por buena parte de los intelectuales y el movimiento estudiantil por aferrarse a una visión distorsionada de la Reforma y a una concepción de la autonomía extrema que pensaba a la universidad por fuera de los conflictos de clase. Por esta razón, esta desviación ideológica era señalada como la principal causante de que el reformismo abandonara su papel progresivo y terminara apoyando el derrocamiento del gobierno peronista ${ }^{242}$.

Muchas veces se habla de las innovaciones y rupturas que trajeron los años sesenta. Sin embargo, sería más preciso resaltar que los nuevos relatos de esta década se realizaron sobre el diagnóstico y la reinterpretación de sucesos precedentes. Ninguna época es el grado cero de la historia, ni puede prescindir de ajustar cuentas con el pasado para pensar el presente y el futuro. Como vimos, organizaciones como el MLN y revistas como Antropología 3er. Mundo fomentaron un espacio de discusión que pivoteó entre la política y la universidad, sin dejar de interrogarse sobre los legados de la Reforma y el peronismo, las dos experiencias que marcaron a fuego el devenir de las casas de estudio en la primera mitad del siglo XX. De todas maneras, no debemos exagerar estas dimensiones en la publicación que dirigió Gutiérrez. Antropología 3er. Mundo no llegó a plasmar un proyecto de universidad y a inicios de los setenta tomó una orientación política que eclipsó algunas lecturas de sus primeros ejemplares, en un momento signado por las controversias internas de las CN, los levantamientos populares en el interior del país, el accionar de las organizaciones armadas y los recambios presidenciales en el gobierno militar.

\section{IV - EL DOCUMENTO AUTOCRÍTICO Y LA PRIMACÍA DE LA POLÍTICA}

\footnotetext{
${ }^{241}$ Ibídem, p. 64.

${ }^{242}$ En el documento del MLN, la Reforma era valorada por haber expresado el ascenso de las clases medias y desarticulado la universidad oligárquica a principios del siglo XX. Ibídem, pp. 8-9.
} 
Antropología 3er. Mundo cumplió su tercer aniversario con la impresión de su séptima entrega. La misma fue titulada "Perón. Pensamiento político y social" y el índice era seguido por una nota aclaratoria que marcaba un punto de inflexión. En ella se explicaba que el proyecto de la publicación hacía un viraje y empezaba a otorgar mayor preponderancia a los análisis políticos y de actualidad. Por eso, este número era concebido como una tirada especial que incluía los discursos de Perón en el gobierno que supuestamente eran menos conocidos por parte de la juventud que irrumpía en el peronismo y formaba parte de la "reelaboración doctrinaria" de esa ideología hacia el socialismo nacional ${ }^{243}$. En el prólogo a la reciente edición facsimilar de la Facultad de Filosofía y Letras, el antiguo director de la revista manifiesta que esa transformación podía advertirse en el logotipo de las últimas tiradas $^{244}$. En las tapas de los primeros ejemplares, Antropología aparecía con una tipografía mayor que 3er. Mundo, mientras que en los últimos esa relación se invierte. Tampoco puede pasar inadvertido que el anteúltimo número de la publicación fechado en agosto-septiembre de 1972 ya no hacía referencia a las ciencias sociales y tenía como subtítulo Revista peronista de información y análisis.

Más allá de estas consideraciones, la preponderancia que Antropología 3er. Mundo otorgó a la cuestión política se explicitó en todas sus dimensiones en "De base y con Perón. Un documento autocrítico de las ex - Cátedras Nacionales”. Este escrito apareció en la décima entrega de junio de 1972 y llevaba la firma de sólo una parte de los profesores que integraron esa experiencia política-pedagógica, entre los cuales estaban Justino O’Farrell, Guillermo Gutiérrez, Gunnar Olsson, Jorge Capio, Néstor Momeño, Norberto Wilner, Roberto Carri, Enrique Pecoraro y Susana $\mathrm{Checa}^{245}$. El documento se presentaba así mismo como un diagnóstico necesario ante una nueva situación signada por la "expulsión" de las $\mathrm{CN}$ de la Facultad de Filosofía y Letras, el accionar de las organizaciones armadas, la asunción de Alejandro Lanusse como presidente de facto, la convocatoria al Gran Acuerdo Nacional (GAN) y el recrudecimiento de los conflictos sociales con los antecedes de Córdoba, Rosario y Tucumán. El nudo central de su autocrítica residía en que las CN sólo habían adoptado una actividad específicamente universitaria y docente. Y a pesar de que habían acompañado la peronización del estudiantado y participado en la coordinadora de agrupaciones que funcionaba en la CGTA, no habrían podido ir más allá de una visión profesional que las

\footnotetext{
${ }^{243}$ Antropología 3er. Mundo, № 7, mayo de 1971, p. 4.

${ }^{244}$ Gutiérrez, G., "Antropología 3er. Mundo. Cuatro décadas, algunas reflexiones sobre el contexto de origen”, en Antropología 3er. Mundo, Edición facsimilar FFyL, UBA, 2009, p. 5.

245 "De base y con Perón. Un documento autocrítico de las ex - Cátedras Nacionales", en Antropología 3er. Mundo, № 10, junio 1972, p. 34.
} 
situaba como un grupo de intelectuales al "servicio de la revolución", por ser portadoras de una especialidad técnica y académica ${ }^{246}$.

Para el sector autocrítico, esa actitud de "fabricantes de teorías" era el origen de una serie de errores que les impedían comprender que sólo la militancia política otorgaba la posibilidad de construir una propuesta verdaderamente vinculada a la experiencia revolucionaria de la clase obrera ${ }^{247}$. A su entender, este límite de "clase profesional" desatendía el eje histórico que venía estructurando los conflictos sociales desde mediados de los cincuenta: la necesidad de construir una "experiencia independiente" de los trabajadores para motorizar una política que resolviera al mismo tiempo la liberación nacional y social ${ }^{248}$. Pero lo más interesante del documento autocrítico era el fuerte cuestionamiento que hacía al resto de los docentes que formaron parte de las $\mathrm{CN}$ y no firmaron el comunicado. Ese sector era acusado de negar el papel decisivo de los trabajadores, mantener una concepción "utópica" de un peronismo sin contradicciones internas, desarrollar un trabajo meramente académico y sobreestimar la nacionalización de la clase media y la peronización universitaria. Como si eso fuera poco, también señalaba que el quiebre interno era producto de la política de Lanusse, la cual pretendía integrar a una parte del peronismo al sistema con el GAN y canalizar la disconformidad de las clases medias. Por otra parte, tampoco puede pasar desapercibida la evaluación del documento sobre la última materia que dictaron las $\mathrm{CN}$ en 1971: Nación y Estado a cargo de O'Farrell ${ }^{249}$. Aunque estuvo dedicada a homenajear a los militantes Manolo Belloni y Diego Frondizi, y participaron gremialistas como Guillán y Di Pascuale, políticos como Licastro y curas del Movimiento de Sacerdotes para Tercer Mundo (MSTM), para el sector autocrítico esas últimas clases no habrían hecho más que encerrar al grupo en sus discusiones internas ${ }^{250}$.

¿Por qué desaparecieron las $\mathrm{CN}$ y un sector de ellas publicó un documento en Antropología 3er. Mundo con fuertes críticas a su propia actuación? Esta problemática está

\footnotetext{
${ }^{246}$ Ibídem, p. 28.

247 Ibídem, p. 31.

${ }^{248}$ Desde esta perspectiva, la Resistencia Peronista, los planes de lucha de la CGTA, las organizaciones armadas y los sectores juveniles eran considerados como manifestaciones de un "camino independiente" de la "burocracia" política y sindical. Ibídem, p. 33.

${ }^{249}$ Nación y Estado era un seminario optativo. Como vimos en el primer capítulo, las materias que no eran obligatorias se denominaban en el plan de estudio como "Sociologías Especiales"”. Véase: Programa No 153. Sociología Especial: Nación y Estado, UBA, Facultad de Filosofía y Letras, primer cuatrimestre 1971.

${ }^{250}$ Ibídem, p. 30. Alcira Argumedo sostiene que las concurrencias a ese seminario optativo fueron masivas y tuvo visitas como las de Darcy Ribeiro. En el cuarto capítulo, hablaremos de la influencia del sociólogo y antropólogo brasilero en la visión de la izquierda peronista sobre la universidad. Entrevista a Alcira Argumedo, C.A.B.A, 01/11/2012. Por otro lado, el propio O'Farrell caracterizaba a ese seminario como "el hecho maldito de la facultad" en una nota de 1971 donde daba por "liquidadas" a las CN. O'Farrell, J., "Mensaje a los compañeros", en Envido, No 4, septiembre 1971, p.75.
} 
relacionada a dos procesos interconectados que se dieron a principios de los setenta. El primero es la mayor influencia política que comenzaron a tener las organizaciones armadas. Sintomático de esta cuestión fue cómo repercutió en distintos ámbitos la interna entre "clasistas" y "movimientistas" de las Fuerzas Armadas Peronistas (FAP), la cual también se conoció como el debate entre "iluminados" y "oscuros". Esto produjo que en 1971 se escindieran de la organización estos últimos y que finalmente la FAP junto al Peronismo de Base (PB) lanzaran la "Alternativa Independiente" ${ }^{, 251}$. El documento autocrítico y la misma línea editorial que terminó adoptando Antropología 3er. Mundo en aquel momento manifestaban un claro acercamiento de una parte de los docentes que integraron las $\mathrm{CN}$ a la "visión alternativista" ${ }^{252}$. Básicamente lo que planteaba la línea "iluminada" o "clasista" era que el único sujeto revolucionario del peronismo era la clase trabajadora y por esa razón había que construir una herramienta organizativa independiente de las "estructuras formales" del movimiento, tanto sindicales como políticas. A su vez, consideraba al marxismo como un elemento privilegiado de análisis político y social. Justamente los docentes que habían formado parte de las $\mathrm{CN}$ y eran cuestionados en el documento autocrítico sin explicitar sus nombres propios, se habían referenciado con una postura "movimientista". Entre ellos estaban Gonzalo Cárdenas, Alcira Argumedo, Pedro Krotsch, Ernesto Villanueva, Juan Pablo Franco, Horacio González y Fernando Álvarez ${ }^{253}$. Su enfoque difería porque, sin dejar de anhelar un horizonte socialista, valoraban al movimiento peronista como una instancia fundamental para encarar la etapa de liberación nacional. Además de que estaban lejos de darle exclusividad a la teoría marxista en el análisis de la realidad social.

El segundo proceso para entender la desaparición de las $\mathrm{CN}$ y el documento autocrítico de Antropología 3er. Mundo está relacionado al viraje del escenario político y universitario. La asunción de Lanusse como nuevo presidente de facto en 1971 implicó una serie de políticas que pretendían llevar adelante una transición controlada hacia el sistema democrático $^{254}$. En este marco, fue designado Alfredo Castellán como interventor de la Facultad de Filosofía y Letras para coordinar el concurso de todos los cargos docentes. Dos de

\footnotetext{
${ }^{251}$ Las FAP surgieron en 1966 y se conocieron en 1968 tras las detenciones de varios de sus dirigentes en la localidad tucumana de Taco Ralo. Para profundizar sobre su interna política a principios de los setenta, véase: Raimundo, M., "Izquierda peronista, clase obrera y violencia armada: una experiencia alternativa", en Sociohistórica, № 15-16, 2004; González Canosa, M., "Las Organizaciones Armadas Peronistas (OAP): un análisis comparativo de los (re) posicionamientos de las FAR, en Tortti, M. C., Ob. cit., 2014.

${ }^{252}$ Un año antes de la publicación del documento autocrítico, Gutiérrez ya había editorializado el octavo número de la revista con una columna de opinión titulada: "El peronismo, desde la base", en Antropología 3er. Mundo, $\mathrm{N}^{\circ} 8$, septiembre-octubre 1971, pp. 1-4.

${ }^{253}$ Varios docentes de las CN tuvieron vínculos con la FAP, pero pocos llegarían a incorporarse verdaderamente a su estructura, como por ejemplo Carri por el lado de los "iluminados" y Villanueva en los "oscuros".

${ }^{254}$ Burgos, R., Los gramscianos argentinos, Bs. As., Siglo XXI, 2004, p. 183.
} 
ellos involucraron a representantes de las $\mathrm{CN}$ y a un integrante de lo que se conoció como Cátedras Marxistas $(\mathrm{CM})^{255}$. El resultado general terminó favoreciendo a este último sector. O' Farrell fue apartado de su cargo de titular de Sociología Sistemática al ser declarado su concurso desierto, mientras Carri perdió su rango de profesor adjunto en esa materia y en Introducción a la Sociología frente a Portantiero. En un primer momento, Sociología Sistemática quedó divida en dos cátedras paralelas que decidieron someterse a la votación del estudiantado para resolver su continuidad. El proceso terminó con la elección del grupo de Portantiero y el paulatino alejamiento de los docentes ligados a O'Farrell, aunque algunas comisiones de trabajos prácticos establecieron acuerdos internos y quedaron formadas por un representante de cada sector, como la compartida por Oscar Landi del Partido Comunista Revolucionario (PCR) y el propio Gutiérrez ${ }^{256}$. En medio de estos cambios, no resulta llamativo que un año más tarde Antropología 3er. Mundo publicara un documento donde pronunciaba una fuerte crítica hacia el interior de las $\mathrm{CN}$ y su desaparición ${ }^{257}$.

Desde una mirada retrospectiva, puede visualizarse claramente que entre 1971 y 1972 la política fue tiñendo cada vez más las páginas de la revista y eclipsó las discusiones de los primeros ejemplares sobre el papel de las ciencias sociales y la práctica intelectual. Esta preponderancia también ensombreció las incipientes controversias sobre universidad que habían comenzado a gestarse en el tercer y cuarto número, con el documento de FORJA y las notas de Cárdenas y Gutiérrez. Sin embargo, esta consideración no tiene que llevar a aceptar en su conjunto la tesis de Beatriz Sarlo, la cual da a entender que la radicalización política y la incorporación de capas medias al horizonte del peronismo revolucionario no hicieron más que disolver la cuestión universitaria en debates de carácter estrictamente político ${ }^{258}$. En verdad, si se analizan más de cerca los cruces y las discusiones que sostuvieron Antropología 3er. Mundo y las $\mathrm{CN}$ con otros actores peronistas y de izquierda a principios de los setenta, es posible reconstruir nuevas lecturas sobre el rol de los estudiantes, la universidad y la Reforma en el momento de irrupción de los cuerpos de delegados en la UBA. En el apartado siguiente, desarrollamos brevemente el itinerario de la revista los Libros con la finalidad de analizar nuevos debates frente a la cuestión universitaria que involucraron a agrupaciones estudiantiles

\footnotetext{
${ }^{255}$ Las CM eran un sector heterogéneo que involucraba a docentes de Filosofía y Letras vinculados a la izquierda, como Portantiero, Oscar Landi e Isidoro Cheresky.

256 Este proceso puede reconstruirse a partir de testimonios de González y Portantiero, aunque sus interpretaciones sobre los concursos difieren. El primero los enmarca en una política del régimen que pretendía excluir a las $\mathrm{CN}$ de la facultad, mientras el segundo considera que los jurados eran aceptables. Véase: Ibídem., pp. 184-186; Tortti, M. C., y Chama, M., Ob. cit., 2005, p. 247.

257 "De base y con Perón. Un documento autocrítico de las ex - Cátedras Nacionales", en Antropología 3er. Mundo, $\mathrm{N}^{\mathrm{0}}$ 10, junio 1972, p. 30. En consonancia con la interpretación actual de González, el artículo denunciaba a los concursos como una expulsión de las CN.

${ }^{258}$ Sarlo, B., Ob. cit., 2000, p. 102.
} 
peronistas, a las CN y a Antropología 3er. Mundo.

\section{V - LOS CUERPOS DE DELEGADOS Y LA MUERTE DE LA REFORMA}

La revista cultural Los Libros surgió en julio de 1969 bajo la influencia de La Quinzaine Littéraire, las agitaciones del Cordobazo y la dirección de Héctor Schmucler, quien en ese momento acababa de terminar sus estudios en Francia con Roland Barthes ${ }^{259}$. A principios de los setenta, la publicación experimentó un giro político y su comité editorial pasó a estar conformado por un pequeño grupo de intelectuales, entre los que se encontraban Sarlo, Carlos Altamirano y Ricardo Piglia. En ese momento, los tres tenían vinculaciones con los dos partidos maoístas más conocidos de la época: Vanguardia Comunista (VC) y el PCR. El primero provenía de una ruptura del Partido Socialista de Vanguardia y en 1969 fundó su brazo estudiantil Tendencia Universitaria Popular Antiimperialista y Combativa (TUPAC), bajo la conducción de Eduardo "Lelel” Horane y Jorge Montero. En cambio, el segundo tuvo su origen en la ruptura de la dirección de la Federación Juvenil Comunista (FJC) en enero de 1968, proceso que permitió la conformación del Frente de Agrupaciones Universitarias de Izquierda (FAUDI) ${ }^{260}$.

En noviembre de 1971, Los Libros editó su vigésimo tercer número con una tapa sugestiva que revelaba el clima de aquellos años. Su título era "Universidad y lucha de clases". Estaba acompañado con una imagen de un aula vacía donde un cartel acaparaba la atención: "Presidente honorario: Che Guevara". La intención era demostrar que los estudiantes estaban en la calle, movilizados y con una clara opción política. Como lo expresaba su portada, esta edición estaba dedicada a discutir el cruce entra política y universidad. Por esta razón, contaba con una reseña de Altamirano sobre dos libros recientes que abordaban la temática, un diagnóstico sobre la experiencia del Taller Total de la Facultad de Arquitectura de Córdoba y hasta escritos dedicados a la reforma de la Universidad de Concepción y a los Guardias Rojos de la revolución cultural china ${ }^{261}$. Estas notas eran

\footnotetext{
${ }^{259}$ La Quinzaine Littéraire era una revista francesa que pretendía intervenir en el ámbito de la crítica y el mercado cultural reseñando libros de literatura, antropología, lingüística, comunicación, psicoanálisis, teoría marxista, filosofía, entre otros. En ella se basó Schmucler cuando fundó Los Libros bajo el subtítulo Un mes de publicaciones en Argentina y el mundo. Somoza, P., y Vinelli, E., "Para una historia de Los Libros", en Los Libros: edición facsimilar, Bs. As., Biblioteca Nacional, 2011, p. 9.

${ }^{260}$ Como señalamos en el primer capítulo, la escisión de la FJC al principio se llamó Comité Nacional de Recuperación Revolucionaria del Partido Comunista de la Argentina y luego PCR. Véase: Gilbert, I., La Fede. Alistándose para la revolución. La Federación Juvenil Comunista 1921-2005, Bs. As., Sudamericana, 2009, p. 520 y 528; Celentano, A., "La actividad de las agrupaciones estudiantiles maoístas entre la lucha antidictatorial y el retorno del peronismo", en Revista em Pauta, Rio de Janeiro, No 33, $1^{\circ}$ semestre de 2014, pp. 157-180.

${ }^{261}$ Altamirano reseñó Imperialismo y universidad en América Latina de Mario Wschebor y la compilación Hacia una política cultural autónoma en América Latina. "Universidad: cultura y dependencia", en Los libros, $\mathrm{N}^{\circ} 23$, noviembre 1971, p. 5.
} 
precedidas por un documento fechado en octubre de 1971, firmado por la agrupación docente 29 de Mayo. La misma pertenecía a la Facultad de Filosofía y Letras de la UBA y estaba compuesta por profesores de izquierda e independientes, en su mayoría militantes del PCR y VC. Su escrito contenía críticas al GAN de Lanusse y una reivindicación de la consigna política que impulsaban los sindicatos clasistas de SITRAM y SITRAC: "ni golpe, ni elección: revolución”. Pero el núcleo de la nota hacía hincapié en la necesidad de promover mecanismos de gestión basados en la asamblea estudiantil-docente y en la actividad de los cuerpos de delegados. Esto sólo sería posible si se lograba superar la falsa antinomia peronismo-antiperonismo que habían impuesto las $\mathrm{CN}$ en su polémica contra el marxismo, como habría quedado demostrado en los conflictos que surgieron alrededor de Sociología Sistemática. Para ellos, los estudiantes y docentes peronistas estaban presos de un "empirismo abstracto y populista" que impedía una verdadera articulación entre las luchas estudiantiles y los objetivos revolucionarios de la clase obrera ${ }^{262}$.

El documento de la agrupación 29 de Mayo manifestaba indirectamente su posicionamiento ante los concursos docentes que impulsó la intervención de Castellán en 1971. Como comentamos anteriormente, la pérdida del cargo de Carri en Sociología Sistemática frente a Portantiero, había permitido la consolidación de las CM y la creciente desarticulación de las $\mathrm{CN}$, en medio de una crisis interna que reflejaba los debates de las FAP y el PB. Sin embargo, las relaciones entre el peronismo y la izquierda eran más complejas que este episodio particular en sí. Tenían momentos de confrontación, como zonas de acción en común. La nota publicada en Los Libros también expresaba un proceso que unía a ambas fuerzas políticas. Desde principios de los setenta, las autoridades de todas las facultades de la UBA habían comenzado a acatar los lineamientos de la ley universitaria de 1967, aplicando cupos y exámenes de ingreso a las carreras ${ }^{263}$. Esto creó las condiciones para que tomaran protagonismo las asambleas de ingresantes y los cuerpos de delegados que reclamaban el fin de las medidas "limitacionistas", junto a lecturas políticas que cuestionaban la parálisis de los centros y las federaciones estudiantiles. Estas experiencias tuvieron fuerte presencia en las facultades de Arquitectura y Filosofía y Letras; generaron debates y contaron con el respaldo de sectores de izquierda y el peronismo.

Sintomático de estas reyertas fueron los eventos que desencadenó la asamblea de

\footnotetext{
262 "La agrupación docente '29 de Mayo' a los compañeros de Filosofía y Letras”, en Los libros, № 23 , noviembre 1971, pp. 3-4.

${ }^{263}$ Seia, G., "La lucha del movimiento estudiantil por el ingreso directo: una aproximación al caso de la UBA entre 1969 y 1973”, en Millán, M. (comp.), Universidad, política y el movimiento estudiantil en la Argentina, Bs. As., Final Abierto, 2014, p. 86.
} 
Filosofía y Letras efectuada el 10 de junio de $1971^{264}$. Luego de su realización, docentes y estudiantes terminaron ocupando las instalaciones en desconocimiento de la intervención de Castellán y hasta asumieron el gobierno de la casa de estudio. Estaban organizados en un cuerpo de delegados que tenía una instancia ejecutiva y sus demandas eran gremiales y políticas: rechazaban la dictadura, la separación de Sociología, Psicología y Ciencias de la Educación de la facultad, los exámenes de ingresos, los planes de estudio, pedían la libertad de los presos políticos y desconocían a los centros de estudiantes y la FUBA. Además de la agrupación docente 29 de Mayo, en la toma participaron alumnos del ingreso, la Cordinadora Nacional de Docentes Peronistas, la Tendencia Estudiantil Revolucionaria Socialista (TERS), el Frente Estudiantil Nacional (FEN), los Comandos Estudiantiles Peronistas (CEP), la Corriente Estudiantil Nacional y Popular (CENAP), el Movimiento de Acción Programática, el FAUDI y TUPAC.

Sucesos similares a lo que se conoció como el "doble poder" de Filosofía y Letras se vivieron en otras facultades y universidades del país. Esto llevó al propio Lanusse a pedir a los rectores-interventores la inmediata erradicación de las asambleas, los cuerpos de delegados y los cogobiernos paralelos de estudiantes y docentes porque demostraban "lenidad en el ejercicio de la autoridad" y la "expansión de focos subversivos" ${ }^{265}$. Desde ya que este tipo de controversias no eran aisladas y formaban parte de las tensiones que azotaban a otros ámbitos de la sociedad. En Autoritarismo y democracia, Marcelo Cavarozzi describe el cuestionamiento de todas las jerarquías tradicionales en el contexto de las movilizaciones populares de fines de los sesenta y principios de los setenta ${ }^{266}$. Los sindicatos, la iglesia y los partidos políticos sufrieron duras impugnaciones a sus dirigencias y a sus formas habituales de representación. En el caso de la universidad, lo interesante fue que las críticas a los centros y las federaciones ponían nuevamente en primer plano las disputas por el significado y la actualidad de la Reforma.

Todo esto podía palparse en el vigésimo primer número de Los Libros, publicado en agosto de 1971 con una tapa que emulaba un famoso afiche del Mayo Francés e inquiría "Por qué Córdoba”. Cómo el título lo indicaba, era una edición que discutía el panorama político tras las movilizaciones de 1969. El sumario contenía un artículo firmado con seudónimos, "El

\footnotetext{
${ }^{264}$ Bonavena, P., "Las luchas estudiantiles en la Argentina 1966/1976", Beca de perfeccionamiento de la Secretaría de Ciencia y Técnica de la UBA, IIGG, Facultad de Ciencias Sociales, 1992. Este trabajo es una base de datos donde pude encontrarse un relevamiento exhaustivo de noticias y acontecimiento vinculados al movimiento estudiantil. En ella están sistematizados diarios nacionales como Clarín, La Nación, La Opinión, La Prensa, La Razón y Noticias.

${ }^{265}$ Lanusse, A., Mensaje reservado a los rectores interventores de las universidades nacionales, 5 de octubre de 1971.

${ }^{266}$ Cavarozzi, M., Autoritarismo y Democracia, Bs. As., CEAL, 1983.
} 
movimiento estudiantil: de la Reforma al Cordobazo", perteneciente a Antonio Marimón y Horacio Crespo, dos jóvenes intelectuales vinculados al $\mathrm{PCR}^{267}$. Su diagnóstico era tajante y recurría a las palabras del mismísimo hijo de Deodoro Roca, que además había sido amigo del "Che" Guevara: "El manifiesto de la Reforma Universitaria de 1918 ha perdido actualidad. Este proceso dio de sí todo, pero no pudo superar su propio carácter pequeño burgués"268. La estrategia de la nota era clara, mostrar un corte abrupto entre el pasado y el presente, entre la generación del Manifiesto Liminar y la generación de la Revolución Cubana. Si el viejo prócer reformista había participado de la incorporación de las clases medias al gobierno de la universidad con el establecimiento del co-gobierno, los centros de estudiantes y sus federaciones; ahora su hijo decretaba la crisis de estos mecanismos de representación. La dictadura y los tiempos radicalizados habían puesto en un primer plano a los cuerpos de delegados y las asambleas estudiantiles como los canales privilegiados de la participación política.

Una lectura similar sobre la Reforma y las estrategias de construcción de poder en la universidad podía observarse en sectores del estudiantado peronista. Era representativa al respecto la última entrega de Cristianismo y Revolución de septiembre de 1971, ya bajo la dirección de Casiana Ahumada y no de su pareja, el recientemente fallecido Juan García Elorrio $^{269}$. En el artículo "Pasión y muerte de una institución”, la CENAP pasaba revista a la experiencia del cuerpo de delegados de Filosofía y Letras de 1971. A su entender, su consolidación se debía a dos hechos inseparables: la creciente participación de los ingresantes en las protestas contra las limitaciones al ingreso y el desprestigio de las visiones reformistas que sólo hacían hincapié en los problemas de la universidad. Ambas cuestiones demostraban la inoperancia de las formas tradicionales de organización estudiantil y el fortalecimiento de opciones de base. A diferencia de los centros y las federaciones, los cuerpos de delegados no reducían la participación al voto anual, no planteaban programas exclusivamente gremiales y construían planes de acción basados en la participación colectiva. Para el análisis de la CENAP, la opción reformista era una "vía muerta". Conseguir el gobierno tripartito, el accionar de los centros o la autonomía ya no garantizaban ninguna alternativa para

\footnotetext{
${ }^{267}$ Los seudónimos eran Osvaldo Reics y Ramón Cuevas. Crespo provenía del grupo Pasado y Presente y Marimón, graduado de la carrera de Letras, era el redactor de la propaganda clasista del PCR para los obreros mecánicos. Burgos, R., Ob. cit., 2004; Crespo, H., "En torno a Cuadernos de Pasado y Presente", en Hilb, C. (comp.), El político y el cientifico, Bs. As., Siglo XXI, 2011.

268 "El movimiento estudiantil: de la Reforma al Cordobazo", en Los libros, No 21, agosto 1971, p. 5.

${ }^{269}$ La revista Cristianismo y Revolución, declaradamente mensual -aunque en lo real fue algo más irregular, llegando a veces a ser quincenal- se publicó entre septiembre de 1966 y septiembre de 1971. Fue dirigida durante sus primeros veintidós números por García Elorrio, ex seminarista y líder del Comando Camilo Torres. Luego de su muerte en 1970, la dirección fue asumida hasta el final por su pareja Ahumada. Gatto, E., "El poder y la plenitud", en Cristianismo y Revolución: edición facsimilar, Bs. As., Biblioteca Nacional, 2015, p. 11.
} 
transformar el régimen proscriptivo que vivía la argentina desde 1955. Lo llamativo era que frente a la autonomía universitaria tradicional, planteaban la independencia absoluta respecto de los formalismos institucionales y académicos. Esto significaba una total separación y rechazo del aparato educativo y hasta el cuestionamiento del liderazgo docente en los procesos pedagógicos. Ningún "paliativo reformista" podía transformar la universidad. La tarea era "crítica" y "destructiva" frente a las instituciones, ya que su verdadera democratización recién llegaría con la liberación nacional y social que habría de encabezar el movimiento peronista ${ }^{270}$.

Este tipo de controversias no estuvieron ausentes en Antropología 3er. Mundo y aparecieron en el momento de su inflexión editorial. Como comentamos anteriormente, a partir de su séptima entrega de 1971, titulada "Perón. Pensamiento político y social", la misma publicación declaró un viraje hacia los análisis de política y actualidad. Estos empezaron a acaparar casi todas las notas y eclipsaron los escritos de los primeros números que dedicaban varias líneas a las ciencias sociales, los intelectuales y la universidad. Sin embargo, la octava edición de ese mismo año reproducía una nota de los CEP que evaluaba la experiencia del cuerpo de delegados de Filosofía y Letras, a la que enmarcaba en el contexto de nacionalización y radicalización de las clases medias. Dicho artículo consideraba a esta instancia organizativa como un lugar privilegiado para instaurar una línea de confrontación contra la dictadura e integrar al estudiantado a las luchas políticas del país ${ }^{271}$. Detrás de esa afirmación taxativa, existía un relato que se diferenciaba de los artículos que habían tratado la cuestión universitaria en los ejemplares iniciales de Antropología 3er. Mundo. A diferencia del Manifiesto de FORJA y las viejas intervenciones de Cárdenas y Gutiérrez, ya no se denunciaban desviaciones de la Reforma y rescataban aspectos positivos de la misma, sino que directamente se la daba por muerta. La participación política del estudiantado era puesta en primer lugar, incluso con exigencias de que los docentes se subordinaran a ella, pero su anclaje no estaba en las "caducas" formas liberales de representación, encarnadas en los centros, las federaciones y el gobierno tripartito. Ahora estos discursos ponían en primer plano la ruptura con el pasado e insistían en el repudio a los que sólo se preocupaban por las reivindicaciones gremiales y universitarias.

Pero declarar la primacía de la política y la defunción de la Reforma no significaba necesariamente descartar esas demandas específicas. La experiencia de los cuerpos de

\footnotetext{
270 "Pasión y muerte de una institución”, en Cristianismo y Revolución, No 30, septiembre 1971, pp. 3-5.

271 "CEP evalúa la experiencia del cuerpo de delegados de Filosofía y Letras", en Antropología 3er. Mundo, No 8, septiembre-octubre 1971, pp. 10-11.
} 
delegados revelaba un panorama mucho más complejo de la politización y radicalización de aquellos años. El mismo artículo del CEP publicado en Antropología 3er. Mundo también mostraba una preocupación por cómo estaban organizadas las carreras, la falta de materias teóricas y las metodologías de evaluación ${ }^{272}$. Los Libros tampoco pasó por alto estos temas y dedicó extensos escritos al respecto. Las notas sobre el Taller Total en la Facultad de Arquitectura de Córdoba, el cuerpo de delegados rosarino o el mismo documento de la agrupación docente 29 de Mayo proponían alternativas pedagógicas para repensar las relaciones entre docentes y estudiantes, las formas tradicionales de evaluación y los contenidos de las asignaturas ${ }^{273}$. Hasta incluso llegaban afirmar que todos las modificaciones propuestas no implicaban hacer una concesión al "espíritu pequeño burgués" que buscaba trampear a la institución universitaria estudiando poco y prestándole escasa atención ${ }^{274}$. Aunque en estos temas, la experiencia de la CENAP fue la más productiva y sistemática. A principios de los setenta, su organización Tendencia Universitaria Popular de Arquitectura y Urbanismo (TUPAU) publicó numerosos folletos y boletines destinados a discutir las particularidades de su facultad y disciplina. Los más sugerentes eran los proyectos de planes de estudio, donde integraban y detallaban todas las dimensiones técnicas, pedagógicas, sociales y políticas de la carrera ${ }^{275}$. En el fondo, existía una fuerte paradoja en el relato de la CENAP-TUPAU. Si pretendía, como vimos anteriormente, un rechazo extremo del aparato educativo ¿cómo era posible que esa tarea "crítica" y "destructiva" se lleve a cabo con la elaboración de programas que hasta detallaban las correlatividades entre el plan anterior del régimen y el nuevo de los estudiantes revolucionarios?

\section{EL RETORNO DEL ESPÍRITU REFORMISTA}

Los discursos político-académicos de esos años eran menos lineales que las hipótesis que relacionan la radicalización y la peronización con la disolución de la cuestión universitaria. No obstante, el paisaje de ese entonces tampoco puede ser reducido a los actores que hablaban de la muerte de la Reforma y reivindicaban los cuerpos de delegados. Si 1971 exaltó los instrumentos de base en el marco de los levantamientos populares que siguieron al

\footnotetext{
272 Ibídem, p. 10.

273 "La agrupación docente 29 de Mayo a los compañeros de Filosofía y Letras"; "Facultad de Arquitectura de Córdoba. La experiencia del Taller Total"; "Facultad de Arquitectura de Rosario. Balance de 6 meses de lucha", en Los libros, $\mathrm{N}^{\circ} 23$, noviembre 1971.

${ }^{274}$ Ibídem, p. 4.

${ }^{275}$ Todos los documentos de CENAP-TUPAU pueden consultarse en FAU. Antología pedagógica. 4 años de producción político-pedagógica del peronismo en la Facultad de Arquitectura de Bs. As volcados en 15 meses de gobierno popular de la universidad., Bs. As., Departamento Pedagógico FAU, diciembre 1974. Este trabajo contiene una serie de propuestas pedagógicas fechadas entre 1967 y 1974. Fue reeditado por la Facultad de Arquitectura Diseño y Urbanismo de la UBA en 2014.
} 
Cordobazo, el fortalecimiento de las organizaciones armadas y los sindicatos combativos; el año siguiente mostró el retorno de los centros de estudiantes y el espíritu reformista, en un escenario signado por fuertes demandas de institucionalizar los conflictos sociales y concretar la salida electoral. Cuando a fines de octubre de 1972, se celebraron elecciones en varias facultades de la UBA -Medicina, Económicas, Ciencias Exactas, Farmacia, Derecho e Ingeniería-, el brazo estudiantil del PC, denominado Movimiento de Orientación Reformista (MOR), resultó inesperadamente ganador en todas esas casas de estudio ${ }^{276}$. Holgadamente en las primeras y de manera ajustada en las dos últimas ${ }^{277}$. Pero el recorrido del triunfo comunista no se agotó ahí y fue aún más sorpresivo. Un tiempo después, Arquitectura y Filosofía y Letras realizaron comicios estudiantiles. Su puesta en práctica implicó muchos debates internos, ya que en esas facultades tenían fuerte injerencia las organizaciones que criticaban a los centros y habían adquirido gran protagonismo sus cuerpos de delegados en el año previo. Durante 1971, en Filosofía habían logrado implementar cátedras paralelas y programas elaborados por docentes y estudiantes. Mientras que en Arquitectura este tipo de medidas había obligado a las autoridades a clausurar preventivamente la facultad por más de cinco meses. Ninguna de esas dos situaciones anteriores impidió que el MOR se consagrara ganador y robusteciera los triunfos del mes anterior ${ }^{278}$.

La victoria del brazo estudiantil del PC demostraba que el escenario universitario de principios de los setenta no podía reducirse a los actores más radicalizados. A diferencia de las voces aparecidas en Antropología 3er. Mundo y Los Libros, el MOR reivindicaba la actualidad de la Reforma y sus organismos de representación. Prueba de ello era el documento de la Comisión Nacional Universitaria del PC aparecido en julio de 1972. En sus páginas, los comunistas criticaban las corrientes que señalaban la defunción del reformismo y posponían la posibilidad de lograr trasformaciones en la universidad hasta lograr la "vuelta de Perón" o la "revolución". Según ellos, había que partir de las demandas específicas de los estudiantes, docentes y graduados para transformar el sistema de educación superior e introducir a estos sectores en la lucha por un gobierno democrático, popular y antiimperialista. No había ninguna razón ni argumento que justificara posponer la reivindicación de la autonomía, el gobierno tripartito y la calidad científica de la institución.

\footnotetext{
${ }^{276}$ Sobre el MOR puede consultarse: Califa, J. S., "A la universidad con banderas reformistas. Los comunistas y la reconquistas de la Universidad de Buenos Aires 1968-1972”, en e - L@tina. Revista electrónica de estudios latinoamericanos, $\mathrm{N}^{\mathrm{o}}$ 56, 2016.

277 "El reformismo marxista ganó los comicios en todos los centros de Buenos Aires", en La Opinión, 1 de noviembre 1972.

278 "El triunfo del reformismo en los comicios de Filosofía. Duro revés para los insurreccionalistas", en $L a$ Opinión, 21 de noviembre 1972; "El reformismo marxista es mayoría absoluta en la FUBA", en La Opinión, 23 de noviembre 1972 .
} 
Además, señalaban que las tendencias radicalizadas terminaban abandonando las batallas dentro de la universidad, al promover asambleas entre el reducido círculo de activistas y al enfrentar a los cuerpos de delegados con los centros de estudiantes ${ }^{279}$.

A pesar de los discursos de los protagonistas, los resultados de los comicios estudiantiles de 1972 también manifestaban que no existía una oposición irreductible entra estas dos instancias de organización. El MOR proclamaba la unificación del movimiento estudiantil en los centros y las federaciones, pero no desconocía los ámbitos de base. En este punto, es necesario tener en cuenta que a contramano de otras facultades, las elecciones realizadas en Filosofía y Letras que nombramos anteriormente pusieron en juego a un "ejecutivo" del cuerpo de delegados y no a un centro de estudiantes; aunque a diferencia del año anterior sus representantes no surgían en asambleas, sino mediante voto secreto. En esta situación, la Lista Violeta Reformista del MOR igualmente desplazó a las otras tendencias de izquierda que venían cuestionando su actuación en esos mismos lugares, como el FAUDI y TUPAC. A su vez, estas dos organizaciones que pertenecían a las corrientes críticas de los centros de estudiantes no renunciaron a participar en las elecciones de dichos espacios en 1972. Si se cuentan los votos en toda la UBA, las dos terminaron a gran distancia del ganador $^{280}$. La situación del FAUDI era la más llamativa ya que cuatro años antes con su surgimiento había deteriorado fuertemente la posición del PC en la universidad al sustraerle la mayoría de sus cuadros, permitiéndole una importante presencia política en las casas de estudio que ostentó hasta la misma victoria del MOR.

De todas maneras, el triunfo comunista no debe sobredimensionarse. Los comicios se realizaron en un contexto de semi-legalidad, el voto no era obligatorio y sólo participó el 10 por ciento del padrón electoral. Tampoco formó parte ninguna de las agrupaciones peronistas que en ese momento contaban con una militancia significativa. La Opinión, el diario de tirada nacional que cubría con mayor profundidad y periodicidad el panorama político de la universidad, llegó afirmar a fines de 1972 que el peronismo era la fuerza política con más respaldo entre el alumnado ${ }^{281}$. Al no contar con su participación en las elecciones es difícil determinar su verdadero grado de inserción. Lo que sí es posible corroborar es que todas las tendencias peronistas mantuvieron la posición de que no era legítimo incursionar en las elecciones estudiantiles en medio de la dictadura, la cual estaba en retirada pero todavía

\footnotetext{
279 "Seis años de dictadura: por una solución democrática, popular y antiimperialista para la universidad y el país”, en Apunte Interno, Comisión Nacional Universitaria del Partido Comunista, 29 de julio 1972.

${ }^{280}$ Los resultados totales de las elecciones de 1972 fueron los siguientes: MOR 8020, FAUDI 2199, Franja Morada 1590, TERS 1567, AUN 1081 y TUPAC 267. "El reformismo marxista es mayoría absoluta en la FUBA", en La Opinión, 23 de noviembre 1972.

281 "El reformismo marxista es mayoría absoluta en la FUBA", en La Opinión, 23 de noviembre 1972.
} 
seguía en pié.

\section{VI - PERONISMo Y UNIVERSIDAD}

En el final del primer capítulo habíamos dejado abierto el interrogante si la peronización porteña impulsó nuevos discursos sobre la universidad, los intelectuales y el movimiento estudiantil. Frente a hipótesis generales que a veces parecieran dar a entender que los protagonistas de esos años sólo priorizaron la política y desatendieron los temas que referían a su ámbito particular, las experiencias que analizamos anteriormente muestran que el panorama era más complejo y menos lineal de lo que se cree. A decir verdad, los grupos que se orientaron hacia el peronismo de izquierda en aquel entonces otorgaron cada vez más centralidad a la política, pero también se vieron obligados a buscar nuevos relatos para la universidad. Esto era una problemática ineludible y difícil de soslayar. El peronismo tenía una historia conflictiva tras de sí con el espacio académico, ya que en los años cuarenta y cincuenta buena parte de sus opositores más activos habían surgido en ese ámbito. Por eso, los universitarios peronizados no sólo tenían que buscar elementos para explicar su nueva pertenencia política, sino también para justificar su presencia en las casas de estudio y sus intenciones de transformarlas.

En relación a las experiencias particulares trabajadas en este capítulo, podemos afirmar que el debate sobre la cuestión universitaria atravesó dos momentos diferentes entre 1968 y 1972. El primero fue a fines de los sesenta y se reflejó en los primeros números de la revista Antropología 3er. Mundo. En ese momento, la publicación y el espacio de las CN se hicieron eco de una controversia más amplia que venía afrontando el campo políticointelectual vinculado a la nueva izquierda desde años anteriores. Esta no era otra que la clásica discusión sobre la conflictiva relación entre el peronismo y las clases medias. De esta manera, se fue esbozando un incipiente discurso que sostenía que para lograr una alianza efectiva entre estos dos polos había que partir de las especificidades organizativas e ideológicas del mundo universitario. Ya no se podía continuar con la vieja metodología de la JUP y los ANDE y creer que la solución a este conflicto sólo consistía en acercar a los estudiantes a las protestas de los trabajadores. Todo lo contrario, ahora había que prestar más atención a la situación particular de las casas de estudio y proponer políticas adecuadas. Si bien ni Antropología 3er. Mundo ni las CN llegaron a plantear un nuevo proyecto de universidad, abrieron una incipiente autocrítica en el papel del peronismo universitario que también se manifestaba cuando hacían alusión a los primeros gobiernos de Perón. De éstos más que nada rescataban su importancia en la democratización social de las casas de estudio. 
Pero a la hora de pensar su papel político en la universidad, recurrieron a FORJA y ahí se encontraron con la Reforma y el Manifiesto Liminar, o por lo menos con una de sus demandas centrales. Para el peronismo de izquierda era imperioso reconocer que la participación política del estudiantado garantizaba una presencia crítica que era capaz de articular la problemática académica con confrontaciones sociales más amplias. Por esta razón no negaban la Reforma, sino que cuestionaban a quienes supuestamente la habían desnaturalizado y encerrado en demandas puramente académicas.

El segundo momento de debate de la cuestión universitaria fue a principios de los setenta cuando se desarticularon las $\mathrm{CN}$ e irrumpieron los cuerpos de delgados en la UBA, en un contexto signado por grandes protestas sociales, el accionar de las organizaciones armadas y los recambios presidenciales en el gobierno militar. Entre 1971 y 1972 se puso en primer plano un discurso fuertemente radicalizado que cuestionó las estructuras políticas y pedagógicas "tradicionales" de la universidad. El mismo podía rastrearse en espacios peronistas y de izquierda, como en las revistas Antropología 3er. Mundo, Los Libros y grupos estudiantiles como CEP, CENAP y FAUDI. A diferencia de la etapa anterior, ahora las voces militantes directamente daban por muerta a la Reforma. La participación política del estudiantado era puesta en primer lugar, incluso con exigencias de que los docentes se subordinaran a ella, aunque su anclaje no estaba en las "caducas" formas liberales de representación, encarnadas en los centros, las federaciones y el gobierno tripartito. Las críticas a estos ámbitos no eran necesariamente nuevas, en el caso del peronismo se podían encontrar en años anteriores, pero lo que sí era innovador era esa pretensión de querer refundar la universidad "desde las bases"”, expresadas en los cuerpos de delegados y las asambleas estudiantiles. Dichas instancias eran consideradas un lugar privilegiado para instaurar una línea de confrontación a la dictadura, pero también para debatir cómo estaban organizados los planes de estudio, las materias y las metodologías de evaluación. Sin embargo, estas propuestas no duraron demasiado y se fueron desarticulando en 1972 a medida que el comunismo triunfaba en las elecciones de centros de estudiantes.

Como vemos en estos dos momentos descriptos anteriormente, el discurso del peronismo universitario en esos años no era lineal y estuvo lejos de sólo preocuparse por temas políticos, incluso en sus expresiones más radicalizadas. Desde ya que no hay que sobredimensionar los relatos anteriores ni tampoco pensar que fueron los únicos. No obstante, estos debates incipientes sobre la cuestión universitaria van a volver a reactivarse al poco tiempo con la vuelta del peronismo al poder en 1973. El retorno al gobierno demandará nuevos posicionamientos y discursos sobre la universidad, los cuales traerán a colación 
muchas de las discusiones previas que trabajamos en este capítulo, especialmente cuando surja una nueva JUP y se produzca todo un reposicionamiento del peronismo de izquierda en las casas de estudio. 


\section{LA PERONIZACIÓN EN LOS ALBORES DE LA PRIMAVERA CAMPORISTA \\ DE la PRoto-JUP A la ASUNCIÓN de PUIGgrós \\ 1972-1973}

En este tercer capítulo abordamos la manera en que se canalizaron organizativamente las experiencias de peronización de universitarios porteños a principios de los setenta. Luego de una introducción referida a cómo interpretaron algunos intelectuales de la época el contexto expectante que generó el retorno de Juan Domingo Perón a la Argentina en 1972 y la elección de Héctor Cámpora como nuevo presidente constitucional en 1973, analizamos la constitución de la Juventud Universitaria Peronista, tomando como antecedente inmediato al proceso de unificación de las Juventudes Peronistas y el surgimiento de la Coordinadora Universitaria Peronista. Finalmente, presentamos el escenario político en el que se enmarcó la designación de Rodolfo Puiggrós como nuevo rector interventor de la UBA el 29 de mayo de 1973, para indagar de dónde provenía la base de docentes e intelectuales sobre la que partió su gestión.

\section{I - EL CRUCE DEL RÍO MATANZAS}

El general Alejandro Lanusse intentó pero no pudo. Finalmente el peronismo, dentro de una coalición política más amplia llamada Frente Justicialista de Liberación Nacional (FREJULI), resultó ganador en las elecciones presidenciales celebradas el 11 de marzo de 1973. La lista encabezada por Héctor Cámpora y Vicente Solano Lima se impuso en los comicios con el 49,56 por ciento de los sufragios. No hizo falta recurrir al régimen de segunda vuelta que había ideado el saliente presidente de facto junto a su ministro del interior Arturo Mor Roig. Ricardo Balbín, candidato a presidente de la UCR por tercera vez en su historia, consiguió un lejano segundo puesto con el 21,29 por ciento de los votos y decidió abandonar la partida. A esa altura, eran escasas las posibilidades de torcer el resultado en un balotaje. La campaña electoral y el mismo triunfo de Cámpora habían demostrado que un amplio arco social depositaba sus expectativas en el FREJULI. Atrás había quedado la fallida "Revolución Argentina" y ahora parecía abrirse un panorama de grandes cambios.

Por lo menos, así lo insinuaba más de una declaración pública de esos años. Sobre 
todo eran sugestivas las voces de personalidades que, en un pasado reciente, habían mostrado posiciones críticas al peronismo. Uno de los escritores más reconocidos del ambiente políticocultural de ese momento era Julio Cortázar, el autor de "Casa tomada", un cuento al que más de una vez se le adjudicaron aires antiperonistas. Unos días antes de los sufragios, había llegado a la Argentina luego de una gira por países de Latinoamérica para asistir al lanzamiento de El libro de Manuel. En la entrevista que le brindó a Osvaldo Soriano, al poco tiempo de su arribo, no sólo describía las implicancias políticas de su nueva novela, sino que era optimista con el momento político que vivía la Argentina: "al frente justicialista le puede faltar una ideología definida, pero expresa un movimiento visceral de todo el pueblo argentino" 282 .

Posturas similares a la de Cortázar eran compartidas por otros actores del campo intelectual que se asumían de izquierda y tampoco tenían un pasado peronista. Un caso que nombramos anteriormente era el de Pasado y Presente. La publicación encabezada por José Arico y Juan Carlos Portantiero había dejado de salir en 1965, pero lanzó su segunda etapa en 1973 bajo una consigna que no ocultaba su optimismo en relación al devenir político: "La larga marcha al socialismo en la Argentina". Para ellos, el triunfo de marzo expresaba el rechazo popular al capitalismo dependiente que había eclosionado unos años antes en el Cordobazo. Por eso, era un paso importante en el camino de articular un movimiento social revolucionario con eje en la clase obrera. Hasta incluso se animaban a decir que el único "voto clasista" era el voto al FREJULI. Sin embargo, vale aclarar que estas expectativas no estaban depositadas en el peronismo en su conjunto, para Pasado y Presente no todos los peronismos conducían al socialismo. Una cosa eran los sectores políticos y sindicales, mientras que otra muy distinta eran los jóvenes y el ala izquierda con sus promesas de revolución y socialización de la economía. La etapa política que luego se conoció como la "primavera camporista" recién comenzaba y les hacía creer que el peronismo podía mutar hacia una opción de masas revolucionaria y dejar de ser un movimiento popular "acaudillado" por la burguesía nacional ${ }^{283}$.

Por testimonios posteriores y trabajos historiográficos, en la actualidad sabemos que los años que comenzaron con la algarabía por el final de la dictadura y la asunción del nuevo gobierno terminaron muy lejanos a los anhelos que venimos describiendo. Pero en ese

\footnotetext{
282 "Julio Cortázar llega a la Argentina convencido de que a pesar de las contradicciones, se consolida la vía al socialismo en América Latina”, en La Opinión, 11 de marzo 1973. La entrevista fue publicada el mismo día de las elecciones, pero ya la había realizado Soriano tres días antes.

283 "El único voto clasista es el voto al FREJULI", en Pasado y Presente, No 1(nueva serie), abril-junio 1973, pp. 141-144.
} 
momento varios actores imaginaban un futuro distinto. Si eran grandilocuentes las declaraciones de algunos escritores e intelectuales que habían cambiado sus opiniones sobre el peronismo, descontamos el frenesí en los que directamente se identificaron con él. Sobre todo en reconocidos docentes universitarios porteños que ahora cantaban loas a su nueva pertenencia política y festejaban lo que en esos años ellos mismos llamaban como la peronización de las canteras jóvenes del estudiantado.

Un caso era el de Conrado Eggers Lan, quien había sido medalla de oro del Colegio Nacional Buenos Aires (CNBA) y en ese momento se desempeñaba como profesor de la Facultad de Filosofía y Letras. En enero de 1972, publicó Izquierda, peronismo y socialismo nacional, un libro donde reflexionaba sobre su actual pertenencia política y confesaba haber sido un activo militante opositor al gobierno de Perón $^{284}$. Al año siguiente continuó la misma línea de lectura con Peronismo y liberación nacional y las respuestas no se hicieron esperar $^{285}$. En el diario La Nación apareció una reseña donde lo criticaban por incurrir en el "panfletismo", negar datos históricos y pretender transformar al peronismo en un "nacionalismo revolucionario tremendista"286. Eggers Lan ya en su propio trabajo de 1973 anticipaba estas críticas y argumentaba que estudiaba los procesos políticos con el mismo rigor que los temas de filosofía antigua ${ }^{287}$. Pero de todas maneras, ¿qué era lo que La Nación señalaba como un optimismo exagerado carente de veracidad histórica? El tema estaba en cómo Eggers Lan leía el momento político que vivía la Argentina y cómo éste impactaba en el mundo universitario. Todo lo que implicaba su respuesta a esos dos interrogantes lo sintetizaba en una imagen: el cruce del "río Matanzas" el lluvioso 17 de noviembre de 1972. En otras palabras, sus grandes expectativas sobre la etapa que estaba viviendo el país las depositaba en que ese día muchos intelectuales, docentes y alumnos porteños habían atravesado "aguas torrentosas" para recibir a un líder político que en sus años de gobierno había logrado un escaso respaldo de esos sectores sociales ${ }^{288}$.

Como sabemos, ese líder finalmente no pudo ser presidente en las elecciones de marzo, pero sí su delegado personal. Por eso, desde el regreso de noviembre hasta la victoria electoral, se podían oír posicionamientos que exhibían el crescendo de optimismo político alrededor del peronismo. No pretendemos recurrir a los testimonios mencionados para evaluar el grado de concordancia que tuvieron con los acontecimientos posteriores. Tampoco

\footnotetext{
${ }^{284}$ Eggers Lan, C., Izquierda, peronismo y socialismo nacional, Bs. As., Ediciones Búsqueda, enero 1972.

${ }^{285}$ Eggers Lan, C., Peronismo y liberación nacional, Bs. As., Ediciones Búsqueda, febrero 1973. El autor dedica el décimo capítulo de este libro a explicar el fenómeno de la peronización del estudiantado a partir de 1966.

286 “Libros político. Cuatro autores y una sola intención”, en La Nación, 7 de mayo 1973.

${ }^{287}$ Eggers Lan, C., Ob. cit., febrero 1973, p. 8.

${ }^{288}$ Ibídem, p. 11.
} 
sobredimensionar este tipo de discursos, ya que existían otras voces con distintos tonos y evaluaciones. Lo que procuramos es situarnos en el corto período de tiempo que comprende los meses anteriores y posteriores a las elecciones de marzo de 1973; con el objetivo de analizar si dentro de ese contexto de expectación alrededor del peronismo, efectivamente se consolidó en las facultades porteñas la peronización de estudiantes, docentes e intelectuales. Y si fue así ¿cuáles fueron sus características particulares y distintivas? ¿Aparecieron nuevas organizaciones para canalizar dicha experiencia? ¿Cómo quedó conformado el panorama del peronismo universitario luego de estos cambios y de qué manera se replantearon los debates con otros actores sociales, políticos y culturales? La imagen de intelectuales, docentes y estudiantes cruzando el "río Matanzas" que evocaba Eggers Lan es un símbolo fuerte porque muestra un quiebre de clivajes históricos precedentes, pero necesita deconstruirse para poder indagar los alcances y los límites de la reconversión política que experimentó el mundo universitario porteño en los setenta, desde un enfoque que sea capaz de pensar cómo se retroalimentaron mutuamente el contexto político y las casas de estudio.

\section{II - EL SURGIMIENTO DE LA JUP}

Once días después de su victoria en las urnas, Cámpora llamó a sus partidarios a mantenerse en estado de alerta y a organizarse en todos los lugares que fueran necesarios. Había pasado un tiempo prudente y todavía el elenco encabezado por Lanusse se negaba a reconocer el escrutinio definitivo de los comicios del 11 de marzo de 1973. Por eso, en su mensaje del 22, el presidente electo le reclamaba al gobierno saliente que sólo se dedique a funciones administrativas e incitaba a todos los militantes a evitar mediante la unión las “intenciones continuistas" de los militares o sus allegados ${ }^{289}$.

Esta declaración pareció tener una repercusión inmediata en la universidad. A un mes del discurso de Cámpora, se anunció la creación oficial de la Juventud Universitaria Peronista (JUP) en la sede central del Partido Justicialista (PJ), bajo la conducción de José Pablo Ventura. El "Tala" era un ex alumno del CNBA que había sido integrante de la Juventud Estudiantil Católica (JEC), del Comando Revolucionario Universitario (CRU) y en ese momento estudiaba en la Facultad de Derecho y Ciencias Sociales de la UBA ${ }^{290}$. Al acto del

\footnotetext{
289 "Hay que defender la victoria”, 22 de marzo 1973, en Cámpora, H., La revolución justicialista, Bs. As., Eudeba, 1973, pp. 74-75.

${ }^{290}$ A fines de los sesenta, el CRU surgió como un grupo de superficie del Comando Camilo Torres que encabezaba Juan García Elorrio, quien fue el director de Cristianismo y Revolución hasta su muerte en 1970. Sobre Ventura, véase: Baschetti, R., La memoria de los de abajo 1945-2007, La Plata, De la Campana, 2007, Tomo II, p. 69; Anguita, E., y Caparrós, M., La voluntad, Bs. As., Planeta, 2013, Tomo I, p. 148, 539 y 700.
} 
23 de abril, no pudo concurrir Rodolfo Galimberti, el flamante representante de la JP en el Consejo Superior del Movimiento Nacional Justicialista (MNJ). Los periódicos dudaban si su ausencia era producto de los supuestos inconvenientes de transporte en su viaje a Mendoza o por los disgustos que había generado su llamado a crear milicias populares en el acto de lanzamiento de la Unión de Estudiantes Secundarios (UES), realizado cinco días antes en el Sindicato de Calzado. Los que sí asistieron fueron los reconocidos Rodolfo Ortega Peña, Arturo Jauretche y el sacerdote Carlos Mugica. Pero la presencia más significativa era la del doctor Rolando García ${ }^{291}$. Su figura representaba los vaivenes que había vivido la universidad argentina y las nuevas opciones políticas que traía la época. El otrora decano de la Facultad de Ciencias Exactas que se había exiliado del país por la represión que sufrió en "La noche de los batones largos", se mostraba como un ferviente partidario del peronismo y adhería al mitín de la JUP en representación del Consejo Tecnológico (CT) del MNJ, que él mismo presidía y había ayudado a crear el 14 de julio de 1972 luego de su encuentro con Perón en Madrid. Este organismo de profesionales se había constituido con la idea de planificar políticas para el futuro gobierno. Su plataforma fundacional recalcaba la importancia de la "doctrina justicialista" y la necesidad de establecer el socialismo nacional en Argentina ${ }^{292}$.

El documento de la JUP leído en su lanzamiento oficial del 23 de abril mostraba aspiraciones similares al CT y seguía los lineamientos que había dado el presidente electo el mes anterior. Sus pasajes más importantes aducían que era necesario profundizar la organización del estudiantado peronista para defender la victorial electoral de marzo, proponer políticas universitarias al gobierno electo y garantizar que ninguno de los funcionarios de la dictadura permaneciera en sus $\operatorname{cargos}^{293}$. Sin embargo, el proceso de constitución de la agrupación que encabezó Ventura era mucho más complejo que una simple respuesta al llamado de Cámpora. El propio relato de la JUP se situaba en una historia amplia y vislumbraba un pasado y un horizonte más profundo que el resultado obtenido en los últimos comicios nacionales. En primer lugar, porque consideraba al propio surgimiento de la organización como resultado de una "gesta" por la liberación nacional y social, que había

\footnotetext{
También son importantes los testimonios de Lorenzo Donohoe para reconstruir su trayectoria, debido a que conoció a Ventura desde la infancia e integró la JUP. Entrevista a Lorenzo Donohoe, C.A.B.A., 27/01/2016.

${ }^{291}$ Para una cobertura del acto de lanzamiento de la JUP, véase: "Mañana se anunciará la creación de la rama universitaria de la JP", en La Opinión, 22 de abril 1973; "Crea expectativa la movilización peronista", en La Nación, 22 abril 1973; "Galimberti dijo cómo serán las milicias”, en La Nación, 23 de abril 1973; "Bases de la JUP”, en La Nación, 24 de abril 1973.

${ }^{292} \mathrm{Su}$ acta fundacional puede consultarse en: "El Consejo Tecnológico del Movimiento Nacional Justicialista", en Ciencia Nueva, $\mathrm{N}^{\circ} 18,18$ de agosto 1972. En el capítulo siguiente, describimos los lineamos principales de la revista Ciencia Nueva.

293 JUP, "El peronismo en la universidad", abril 1973. Reproducido en Aportes para la nueva universidad, Secretaría de Planeamiento, UNPBA, No 1, julio 1973, pp. 26-27.
} 
tenido sus huellas más importantes en el 17 de octubre, la Resistencia, las huelgas sindicales de 1964, la CGT de los Argentinos (CGTA), los “cordobazos" y en la aparición de las organizaciones armadas. En segundo lugar, porque dejaba entrever que la victoria electoral no significaba la "verdadera" conquista del poder. Ésta recién llegaría cuando se garantizara el control de todos los resortes económicos, políticos, militares y culturales del país, mediante lo que caracterizaban como una "guerra popular revolucionaria". No está demás resaltar que cuando abordaba este último punto, la JUP denunciaba que existían sectores internos del FREJULI que pretendían utilizar las elecciones para "domesticar" al peronismo, como ya lo había intentado el general Lanusse al lanzar el GAN ${ }^{294}$.

\section{La unificación de las Juventudes Peronistas}

Antes de indagar en las interpretaciones que hacían los propios actores sobre su historia y sus opciones políticas, claramente orientadas a legitimar su lugar en el interior del peronismo y a diferenciarse de otros sectores del movimiento con los que disputaban espacios, es necesario preguntarse cómo fue posible el surgimiento de la JUP. Para responder al interrogante, podemos delimitar factores que respondían a la dinámica del escenario político nacional y otros vinculados al reordenamiento de las fuerzas político universitarias. Los primeros estaban relacionados con el proceso de unificación de los heterogéneos agrupamientos juveniles del peronismo. Esta experiencia fue compleja e involucró a distintos actores, incluido al mismo Perón. Uno de sus momentos clave se produjo durante el bienio 1971-72, cuando el viejo líder trazó una estrategia de oposición contra el régimen militar que comprendía no sólo el diálogo y la articulación con otros partidos políticos, sino la puesta en primer plano de la juventud y la caracterización de la guerrilla peronista como las “formaciones especiales" del movimiento. Para eso, reemplazó a Jorge Daniel Paladino por Cámpora como su delegado personal, designó a Juan Manuel Abal Medina como secretario general y nombró a Rodolfo Galimberti y Julián Licastro como representantes de la nueva rama juvenil en el Consejo Superior del $\mathrm{MNJ}^{295}$. Su idea inicial era que el líder de las Juventudes Argentinas para la Emancipación Nacional (JAEN) se encargara del aspecto organizativo; mientras que el teniente que había sufrido el retiro forzoso del Ejército después

\footnotetext{
${ }^{294}$ Ibídem, p. 18 y 28.

295 El 9 de noviembre de 1971 fue designado Cámpora como representante personal de Perón en lugar de Paladino, mientras a Abal Medina lo nombraron secretario general del MNJ el 2 de noviembre de 1972. El Consejo Superior del MNJ era la instancia máxima de organización política. Estaba por encima del Consejo Nacional del Partido Justicialista, el organismo partidario que había sido formalmente reconocido para actuar políticamente por el gobierno militar. Bernetti, J., El peronismo de la victoria, Bs. As., Colihue, 2011, p. 45 y 50 .
} 
del Cordobazo dedicara sus esfuerzos al desarrollo doctrinario de los cuadros juveniles. Siguiendo esa dirección, Galimberti constituyó en enero de 1972 el Consejo Provisorio de la $J P$ junto a Alberto Brito Lima. La alianza duró poco, ya que el referente del Comando de Organización $(\mathrm{CdeO})$ decidió apartarse rápidamente por diferencias políticas ${ }^{296}$.

De todas maneras, el mayor intento por agrupar a todo el conglomerado de grupos juveniles se realizó con el “Acto de Unidad” en la Federación Argentina de Box y la creación del Consejo Nacional Reorganizador de la JP, el 9 de junio de ese mismo año. Pero a pesar de las consignas y los llamados exultantes, la fraternidad estaba minada de antemano y existían de hecho dos grandes nucleamientos juveniles. Uno estaba integrando por los sectores que se habían alineado tras la figura de Galimberti y reivindicaban directamente la política de las organizaciones armadas peronistas. La columna vertebral de esta entente reposaba en la articulación que habían entablado el histriónico delegado juvenil y Montoneros, agrupación guerrillera que en esos momentos ostentaba una fuerte presencia política debido a su impactante aparición pública, tan sólo dos años atrás con la ejecución del general Pedro Eugenio Aramburu ${ }^{297}$.

La otra vertiente juvenil giraba sobre la Mesa de Trasvasamiento Generacional y era encabezada por el Movimiento de Bases Peronistas (MBP) de Roberto Grabois ${ }^{298}$ y Guardia de Hierro (GH) de Alejandro Álvarez, donde también militaba el antiguo dirigente estudiantil humanista Julio Bárbaro ${ }^{299}$. Esta alianza, si bien establecía fuertes críticas a la dictadura y se reconocía como parte del peronismo combativo, era reticente a encolumnarse detrás de los grupos guerrilleros y privilegiaba la "lucha política" sobre la armada. En un principio, formaban parte de la Mesa el teniente Licastro, Dardo Cabo y los cineastas Fernando Solanas

\footnotetext{
${ }^{296}$ Bartoletti, J., Montoneros: de la movilización a la organización. Un caso paradigmático de militarización, Tesis Doctoral, UNSAM, 2010, p. 34; Larraquy, M., y Caballero, R., Galimberti. De Perón a Susana, de Montoneros a la CIA, Bs. As., Aguilar, 2011, pp. 149-151.

${ }^{297}$ El vínculo entre Galimberti y Montoneros se remonta a 1970. Después de la toma de La Calera, los jefes de la organización establecieron un asiduo contacto con él y otro dirigente del JAEN: Ernesto Jauretche. Ambos operaban como canal de comunicación con diferentes sectores del peronismo. Entrevista a Ernesto Jauretche, La Plata, 15/01/2016; Lanusse, L., Montoneros. El mito de sus 12 fundadores, Bs. As., Vergara, 2007, p. 251.

298 Por los contactos que estableció en la CGTA al concurrir constantemente en representación del Frente Estudiantil Nacional (FEN), Grabois trabó relaciones con Delfino Pérez, quien dirigía a fines de los sesenta la comisión interna de la Fábrica Argentina de Engranajes. De estos contactos políticos, surgió en 1970 el MBP. Grabois, R., Memorias de Roberto Pajarito Grabois. De Alfredo Palacios a Juan Domingo Perón (1955-1974), Bs. As., Corregidor, 2014, p. 204.

${ }^{299}$ Bárbaro se incorporó a GH en 1969 cuando todavía era presidente de la Liga Humanista de Buenos Aires. El principal contacto que lo introdujo a la organización fue el "gallego" Álvarez. Entrevista a Julio Bárbaro, C.A.B.A., 21/01/2016; Bárbaro, J., Juicio a los '70, Bs. As., Sudamericana, 2009, pp. 86-87. Por otra parte, Cucchetti ha señalado el error de identificar a GH con el mote de "derecha", sus orígenes se remontan a principios de los sesenta a un desprendimiento del Comando Nacional Peronista (CNP) que encabezaron César Marcos y Raúl Lagomarsino. El CNP era parte de los sectores "duros" de la resistencia peronista e incluso por su línea intransigente había llegado a cuestionar la decisión de Perón de fomentar el voto a Arturo Frondizi. Cucchetti, H., Combatientes de Perón, herederos de Cristo, Bs. As., Prometeo, 2010, p. 75.
} 
y Octavio Getino. Pero todos ellos se alejaron al poco tiempo. Licastro continuó en el Comando Tecnológico Peronista (CTP); mientras Cabo sumó su Agrupación Peronista de Base 17 de Octubre (APEBA-17) a Descamisados, grupo armado encabezado por Norberto Habegger, Horacio Mendizábal y Oscar De Gregorio que se diluiría al poco tiempo en Montoneros $^{300}$. Con este panorama, la Mesa de Trasvasamiento Generacional quedó reducida al MBP y a GH, quienes ya habían formado a principios de 1972 la Organización Única de Trasvasamiento Generacional (OUTG), junto a otros grupos del interior del país ${ }^{301}$.

A sólo un mes del mencionado acto en la Federación Argentina de Box, el tándem Montoneros - Galimberti terminó conformando la Juventud Peronista Regionales (JP Regionales) $)^{302}$. Este nucleamiento fue el que más creció al canalizar a la mayor parte de sectores medios que se acercaron al peronismo, en lo que algunos llamaron la "época del engorde". Un momento crucial en su ascendencia estuvo vinculado al protagonismo que asumió en el regreso de Perón a la Argentina a principios de los setenta. Mientras más de un agrupamiento peronista dudaba del retorno, teniendo en cuenta la experiencia fallida de 1964, Montoneros y la JP Regionales lanzaron la consigna Luche y Vuelve ${ }^{303}$. El desenlace favorable vivido el 17 de noviembre de 1972 les otorgó un protagonismo que siguieron ostentando durante la campaña electoral. Este proceso terminó de afianzarse en los albores de 1973, cuando Montoneros decidió lanzarse a la creación de una estructura federal articulada en frentes de masas, con el objetivo de robustecer el trabajo de superficie que venían realizando el mismo Galimberti y la JP Regionales ${ }^{304}$. En este marco, fueron creadas la propia

\footnotetext{
${ }^{300}$ Descamisados se integraría a Montoneros a fines de 1972. Como señalamos en el primer capítulo, Habbeger, Mendizábal y De Gregorio eran ex militantes de Democracia Cristiana que habían formado los Grupos Marcha con Bárbaro a fines de los sesenta. Cabo creó APEBA-17 en 1970, pero Mendizábal lo convenció de abandonar la Mesa de Trasvasamiento Generacional. Castro, F. y Salas, E., Norberto Habegger. Cristiano, descamisado, montonero, Bs. As., Colihue, 2011, p. 45.

${ }^{301}$ El propio Grabois afirma que tuvo su primer contacto con GH gracias a Bárbaro, con quien había participado en la película La Hora de los Hornos y formado parte de la articulación de la CGTA y el movimiento estudiantil a fines de los sesenta. Grabois, R., Ob. cit., 2014, p. 316, 341 y 351.

${ }^{302}$ La fecha exacta fue el 9 de julio de 1972. Véase: “El país se pregunta: ¿Qué es la Juventud Peronista?”, en El Descamisado, № 8, 10 de julio 1973.

${ }^{303}$ La desconfianza ante la posibilidad del retorno de Perón era compartida por distintos actores, como GH, el PB y el sindicalista Juan José Taconne. Bernetti, J., Ob. cit., 2011, p. 47.

${ }^{304}$ González Canosa muestra que al principio todas las organizaciones armadas peronistas desconfiaban de la salida electoral, pero luego Montoneros decidió participar activamente en ella. También que desde 1971 fue una preocupación importante del grupo armado su vinculación con organizaciones de "superficie". Por eso, incorporó las Unidades Básicas Revolucionarias (UBR) a su estructura. Las UBR eran un nivel intermedio dentro de Montoneros que debía oficiar de nexo con las agrupaciones de base. Sus miembros estaban encuadrados en la organización, pero no abandonaban la militancia de "superficie" en los frentes de masas. González Canosa, M., "Las Organizaciones Armadas Peronistas (OAP): un análisis comparativo de los (re) posicionamientos de las FAR", en Tortti, M. C. (dir.), La nueva izquierda argentina (1955-1976): socialismo, peronismo y revolución, Rosario, Prohistoria Ediciones, 2014, pp.145-146. A su vez, para entender la estructura organizativa de Montoneros y la JP Regionales puede consultarse: Perdía, R., "Cómo era "la Orga", en Montoneros. El peronismo combatiente en primera persona, Bs. As., Planeta, 2013, pp. 181-187.
} 
JUP, la UES, los Equipos Político-Técnicos, la Juventud Trabajadora Peronista, la Agrupación Evita, el Movimiento de Inquilinos Peronistas y el Movimiento de Villeros Peronistas. Todos estos espacios que se estructuraron bajo la conducción de Montoneros fueron conocidos como la Tendencia Revolucionaria del peronismo. No obstante, es necesario aclarar que dicho conglomerado político no se reducía a los sectores que nombramos anteriormente, dado que era más amplio y heterogéneo. Involucraba a otras organizaciones guerrilleras como Descamisados, las Fuerzas Armadas Revolucionarias (FAR) y las Fuerzas Armadas Peronistas (FAP), a agrupaciones políticas como el Peronismo de Base y a grupos profesionales, como la Agrupación de Abogados Peronistas y el Consejo Tecnológico de Rolando García ${ }^{305}$. Por esta razón, en los siguientes apartados podemos referirnos a sectores que eran de la Tendencia, pero no de la estructura orgánica de Montoneros y la JP Regionales, el núcleo hegemónico de la izquierda peronista.

\section{EL SUSTRATO MILITANTE PREVIO: DE LA PROTO-JUP A LA JUP}

De todas maneras, sería un grave error suponer que el surgimiento de la JUP sólo estuvo relacionado con cambios superestructurales que operaron de arriba hacia abajo, en el contexto de consolidación de los frentes de masas de la JP Regionales y de la Tendencia en su conjunto. A decir verdad, su modo de emergencia era muy distinto al de la vieja Confederación General Universitaria (CGU), la cual había aparecido en tiempos del primer peronismo por una simple decisión oficial y sin un gran correlato anterior de militancia estudiantil organizada que le sirviera de soporte. Ya había corrido mucha agua bajo el puente y los años setenta mostraban un panorama diferente al de los cuarenta y cincuenta, tiempo en el que habían sido nulas las articulaciones políticas eficaces para resolver el desencuentro entre peronistas y universitarios.

Por lo tanto, es necesario resaltar que la aparición de la JUP no sólo dependió de la unificación juvenil más amplia que impulsaron a su manera Perón, Montoneros y otros actores del movimiento, sino que jugaron un papel clave el conjunto de organizaciones estudiantiles que se habían desarrollado previamente al calor de la peronización de capas medias universitarias. Es importante recordar que el acto inaugural de la JUP del 23 de abril

\footnotetext{
${ }^{305}$ En este punto, no debe pasarse por alto el proceso de fusión que llevó adelante Montoneros con otras organizaciones armadas desde 1972. A fines de ese año, se unen con Descamisados, en octubre de 1973 con FAR y más adelante, en junio de 1974, con el sector de las FAP liderado por Carlos Caride. Por otra parte, es necesario tener en cuenta que las FAR jugaron un papel importante en la formación de los frentes de masas de la JP Regionales que nombramos anteriormente. Lenci, M. L., "Cámpora al gobierno, Perón al poder. La Tendencia revolucionaria del peronismo antes de las elecciones del 11 de marzo de 1973”, en Pucciarelli, A. (ed.), La primacía de la política, Bs. As., Eudeba, 1999, p. 174.
} 
de 1973 convocó a veintiocho agrupaciones de Capital Federal, Santa Fe, Córdoba, Chaco, Corrientes, Misiones, Formosa, La Plata, Rosario, Mar del Plata y Bahía Blanca ${ }^{306}$. Por su puesto que no pretendemos afirmar de antemano que la entidad resultante tuvo el mismo peso en todos los distritos. Habría que analizar cada lugar en profundidad y los itinerarios que convergieron en ellos. Pero sí que la convocatoria del acto fundacional obliga a rastrear el sustrato militante previo que la hizo posible.

En el caso de la UBA, la constitución de la JUP se vivió con intensidad porque fue respaldada por una red de activismo sedimentada en años precedentes. Un momento ineludible fue la formación de la Coordinadora Universitaria Peronista (CUP) en 1972. Esta entidad, que podría considerarse como la proto-JUP, surgió a raíz de un conjunto de agrupaciones que lograron tejer una militancia política común y absorber a un conjunto de estudiantes que en buena medida provenían de ámbitos no peronistas. La articulación cobró dinamismo a partir de su participación en las protestas de los cuerpos de delegados contra las restricciones al ingreso y los planes de estudio de la dictadura. Como vimos en el capítulo anterior, estas experiencias de base tuvieron gran protagonismo en las facultades de Arquitectura y Filosofía y Letras a principios de los setenta.

Por esta razón, no era casualidad que los principales focos de la CUP estuvieran afincados en esos dos espacios. En la primera de dichas facultades, residía la Tendencia Universitaria Popular de Arquitectura y Urbanismo (TUPAU), entidad estudiantil surgida en 1967, donde militaban Norberto Chávez, Alberto Bello, Horacio Machi, Roberto Corvaglia y Jaime Sorín $^{307}$. En esos años, la TUPAU formaba parte de la Corriente Estudiantil Nacional y Popular (CENAP), la cual había surgido en 1968 gracias a su unión con la Corriente Estudiantil Antiimperialista (CEA) de Derecho y la Tendencia Antiimperialista Universitaria (TAU) de Filosofía y Letras; dos agrupaciones que participaron en la fundación del Frente Estudiantil Nacional (FEN), pero se escindieron rápidamente. En la casa de estudio de Viamonte, la CENAP no contaba con el mismo peso que en Arquitectura y entre sus integrantes estaban Ernesto López, Silvia Sánchez y León Repetur ${ }^{308}$.

\footnotetext{
${ }^{306}$ Véase: "Mañana se anunciará la creación de la rama universitaria de la JP”, en La Opinión, 22 abril 1973 ; JUP, "El peronismo en la universidad", abril 1973. Reproducido en Aportes para la nueva universidad, Secretaría de Planeamiento, UNPBA, No 1, julio de 1973, pp. 31-32.

${ }^{307}$ Corvaglia provenía de una familia radical, mientras Sorín había realizado sus primeros pasos de militancia en el PC. Entrevista a Roberto Corvaglia, C.A.B.A., 11/09/2015; Entrevista realizada a Jaime Sorín por Juan Molina y Vedia, C.A.B.A., 16/06/2015. Disponible en http://archivosdarentrevistas.blogspot.com.ar.

${ }^{308}$ López había militado en la agrupación Carta Abierta. Según Acha, la misma era el brazo universitario de los Comandos Populares para la Liberación (CPL), una organización creada por iniciativa de Eduardo Jozami y Oscar Terán, dos militantes que se alejaron del PC atraídos por la Revolución Cubana. Acha, O., "La autocrítica de la intelectualidad revolucionaria: Oscar Terán y la historia de las ideas argentinas", en Revista Herramienta, No 59, primavera 2016; Entrevista a Ernesto López, C.A.B.A., 18/05/2016; Corvaglia, R., "La militancia al
} 
Sin embargo, el panorama de grupos era más variado en Filosofía y Letras. Entre los sectores que terminaron en la CUP, también estaban los Comandos Estudiantiles Peronistas (CEP) y la Federación Nacional de Estudiantes Peronistas (FANDEP). A esta última, el mote de "federación" le quedaba grande en esos tiempos. Ya no agrupaba como a mediados de los sesenta a los distintos ANDE del país y su activismo había quedado reducido al ámbito porteño. Aunque a inicios de los setenta, atravesó un recambio generacional con el ingreso de Roberto Marafioti, Irma Parentella, Jorge Gercovich, Jorgelina Aglamisi y Nora Rabotnikof $^{309}$. Por su parte, el CEP tenía sus principales militantes en la carrera de Sociología. Los más destacados eran el antiguo activista de JAEN Horacio Pietragalla, Leonardo Bettanin, Norberto Ivancich y Marcelo Cerviño. Los dos últimos habían integrado el Movimiento Humanista Renovador (MHR) ${ }^{310}$.

A los núcleos de Arquitectura y Filosofía y Letras de la CUP, se sumaría otro que iría adquiriendo importancia con el correr del tiempo. En un principio se los conocía como los "barbudos" y después como las Bases Peronistas de Derecho. Era el grupo liderado por dos ex estudiantes del CNBA: Miguel Talento y el nombrado Ventura ${ }^{311}$. Al poco tiempo, las Bases se extendieron a la Facultad de Económicas gracias a la militancia de Lorenzo Donohoe y también a Ingeniería ${ }^{312}$.

Todos los focos militantes que constituyeron la CUP (CEP, CENAP, FANDEP y las Bases) fueron la columna vertebral de la JUP en 1973. Desde ya que esto no sólo se debió a su participación en las protestas de los cuerpos de delegados. Intervención, por otra parte, que fue mucho más clara en el caso de CENAP, CEP y las Bases que en FANDEP, la cual era más reacia a la militancia estudiantil y estaba más preocupada por el reclutamiento de cuadros políticos. Pero esa inserción fue un factor de crecimiento que luego se combinó con el impulso político que trajo el retorno de Perón y la campaña electoral. Para sintetizar, podemos afirmar que la CUP se fortaleció y tuvo un papel central en la conformación de la JUP, porque no había sido ajena a los conflictos estudiantiles de principios de los setenta y porque se referenció con uno de los sectores del peronismo que más creció cuando comenzó a materializarse el retorno de Perón en 1972 y las elecciones de 1973. No por nada, CEP,

servicio de la causa nacional y popular en los claustros universitarios", en Baschetti, R., Peronistas que estudian. De los libros de lectura a la lectura de la realidad, Bs. As., Jironesdemivida, 2016, p. 186.

${ }^{309}$ Entrevista a Roberto Marafioti, C.A.B.A., 06/01/2016 y 19/01/2016.

${ }^{310}$ Ramus, S., Sueños sobrevivientes de una montonera a pesar de la ESMA, Bs. As. Colihue, 2000, p. 14; Entrevista a Arturo Armada, C.A.B.A., 15/12/ 2015 y 29/12/2015.

${ }^{311}$ Entrevista a Miguel Talento, C.A.B.A., 11/01/2016 y 04/05/2016; Talento, M., "Sobre el '73: algunas reflexiones y recuerdos", en Baschetti, R., Ob. cit., 2016, pp. 209-211; Talento, M., "Sobre ilusiones, represión y memoria en el '73”, en Testimonios. A 25 años del golpe, CABA, FUBA/UBA/Página 12, 2000, pp. 68-79.

${ }^{312}$ Entrevista a Lorenzo Donohoe, C.A.B.A., 27/01/2016. 
CENAP, FANDEP y las Bases fueron las agrupaciones estudiantiles que más se identificaron con la JP Regionales y Montoneros.

Cuando argumentamos que puede considerarse a la CUP como la proto-JUP, no estamos afirmando que sus organizaciones fueron las únicas que terminaron conformado el frente de masas universitario de la JP Regionales en abril de 1973. También participaron otras agrupaciones estudiantiles que en un principio no compartían un apoyo tan explícito a la guerrilla peronista. Una de ellas era la Fuerza para la Organización Revolucionaria Peronista (FORPE), surgida a raíz de la ruptura de JAEN que encabezó Carlos Álvarez en 1970. Junto al "Chacho" se habían alejado los frentes barriales de Saavedra y Munro, como militantes universitarios de Derecho y Filosofía y Letras, entre los que se encontraban Ricardo Mitre, Alberto Iribarne, Omar Estela y Mirtha Grosso ${ }^{313}$. Otra de las organizaciones era la Agrupación de Estudiantes Peronistas (AEP), la cual era parte del Movimiento Revolucionario Peronista (MRP), donde militaban Miguel Hurst y Darío Alessandro. Hurst, por su parte, había sido el principal dirigente del MHR y era propietario de Cimarrón, una liberaría donde concurrían alumnos y docentes de Filosofía y Letras ${ }^{314}$. Además, en la Facultad de Derecho existían otros focos estudiantiles que no integraban la CUP pero terminarían formando parte de la JUP, como el Movimiento Social Cristiano, el Frente de Acción Nacional y el Movimiento Independiente Nacional.

\section{III - CLIVAJES DEL PERONISMO UNIVERSITARIO Y PANORAMA ESTUDIANTIL PORTEÑO}

En 1973 el mapa del peronismo universitario no se agotaba en los sectores que formaban parte de los frentes de masas conducidos por Montoneros. El panorama era más diverso y estaba surcado por los mismos clivajes que dividían a la juventud peronista en su conjunto. Como señalamos anteriormente, a la par de la articulación JP Regionales Montoneros se conformó otro conglomerado juvenil a principios de los setenta. Era el sector que giraba sobre la Mesa de Trasvasamiento Generacional. En un principio, formaron parte de ella varios grupos, pero luego quedó reducida a la OUTG que habían constituido el MBP de Grabois y GH del “Gallego” Álvarez, a principios de $1972^{315}$. La formación de la OUTG

\footnotetext{
${ }^{313}$ Larraquy, M., y Caballero, R., Ob. cit., 2011, pp. 115-116.

${ }^{314}$ En el siguiente capítulo, volveremos a nombrar a Hurst y el papel relevante que tuvo en la revista Envido, aparte de analizar en profundidad el origen y la trayectoria del MHR.

${ }^{315}$ La OUTG estaba compuesta por un mando colegiado en cuya cabeza se encontraba Álvarez (GH), acompañado de Grabois (MBP-FEN), Eduardo Ceballos (FEN Rosario), Pedro González (GH) y Lorenzo Gatica (Agrupación Nacional Peronista de Córdoba). Además, tenía un "Estado Mayor" liderado por Fabio Bellomo (GH), cuya función era dotar de elementos materiales y cognitivos a la conducción para la realización de actividades políticas bajo un esquema militar. Cucchetti, H., Ob. cit., 2010, p. 157; Grabois, R., Ob. cit., 2014 , p. 355.
} 
tuvo un correlato inmediato en la universidad porteña, debido a que los grupos estudiantiles que respondían a ambos espacios terminaron por unificarse. De esta manera, ya no existía el FEN ni la Organización Universitaria Peronista (OUP) por separado, sino el FEN-OUP. Esta vertiente no ingresó a la JUP dado que siguió la política más general de la OUTG de diferenciarse de las organizaciones armadas ${ }^{316}$.

En una carta a Perón fechada el 15 de mayo de 1972, Galimberti señalaba con cierto desdén que este agrupamiento era el único sector juvenil que criticaba a las "formaciones especiales" y promovía la campaña de afiliación al PJ sólo para obtener "pequeños réditos políticos"317. A pesar de las afirmaciones interesadas del representante de la JP en el Consejo Superior del MNJ, lo cierto era que el FEN-OUP como toda la OUTG estaba lejos de ser una organización reaccionaria o de derecha como el Sindicato de Derecho o la Concentración Nacional Universitaria $(\mathrm{CNU})^{318}$. Sintomático de esta cuestión fue el Primer Cabildo Abierto del Peronismo Universitario que realizaron el FEN y OUP el 15 y 16 de abril de 1972 en la ciudad de Córdoba. En el encuentro, además de resaltar su lealtad a Perón o la importancia táctica del PJ, hablaban de la "guerra revolucionaria" para la toma definitiva del poder y la construcción del socialismo nacional ${ }^{319}$. Esto no dejaba de ser una consigna abstracta, pero no era inusual en aquel entonces encontrar puntos en común entre los sectores juveniles que terminaron distanciados. Por otra parte, conviene recordar que el FEN había compartido espacios militantes con CEP, CENAP y FANDEP, sobre todo, cuando a fines de los sesenta la CGTA logró nuclear a su alrededor a distintos activistas estudiantiles.

El escenario de la JP en su conjunto y de las agrupaciones estudiantiles peronistas carecía de linealidad y tenía varias aristas. No obstante, los que pudieron obtener mayor protagonismo durante el retorno de Perón y los comicios presidenciales fueron los sectores que se posicionaron detrás de la JP Regionales y Montoneros. Con este impulso, se terminó conformando la JUP a sólo un mes del triunfo electoral de marzo del '73. Si miramos en retrospectiva, esta experiencia muestra una novedad histórica en la UBA. A diferencia de las primeras gestiones de Perón que recibieron desde un inicio la oposición del grueso del

\footnotetext{
${ }^{316}$ Según Bonavena, la OUP surgió en 1969. Por otra parte, entre los docentes que ingresaron a la OUTG vía GH podemos nombrar a Amelia Podetti, la ex integrante de las Cátedras Nacionales de la Facultad de Filosofía y Letras. Bonavena, P, "El peronismo estudiantil universitario 1966/1970", en XI Jornadas de Sociología de la $U B A, 2015$, p. 14; Denaday, J. P., "Amelia Podetti: una trayectoria olvidada de las Cátedras Nacionales", en Nuevo Mundo Mundos Nuevos, 2013.

${ }^{317}$ Carta de Rodolfo Galimberti a Juan Domingo Perón, 15 de mayo 1972, en www.cedema.org/ver.php?id=227.

${ }^{318}$ Como afirmamos en una cita anterior, el trabajo de Cucchetti muestra el error de caracterizar a $\mathrm{GH}$ o a la OUTG como organizaciones de la derecha peronista. Cucchetti, H., Ob. cit., 2010, p. 22.

319 "Documento de agrupaciones universitarias peronistas. Primer Cabildo Abierto del Peronismo Universitario", en Envido, № 6, julio 1972, pp. 74-75. También puede consultarse: "Unión para la batalla", en Primera Plana, $\mathrm{N}^{\circ} 482,25$ de abril 1972.
} 
movimiento estudiantil, el electo presidente Cámpora ahora recibía apoyos explícitos en el activismo universitario.

No obstante, el respaldo de la JUP debe comprenderse en su forma de politización particular. El documento de su lanzamiento oficial del 23 de abril era representativo al respecto. Como señalamos anteriormente, la agrupación de Ventura respaldaba al gobierno y pretendía proponerle políticas universitarias a llevar adelante, pero al igual que Montoneros caracterizaba que la "verdadera toma del poder" recién llegaría con la "guerra popular y prolongada" ${ }^{, 320}$. En este punto, manifestaba una tensión entre la lógica político-institucional y la lógica revolucionaria. Esta ambivalencia había cruzado desde sus inicios a Montoneros y a la JP Regionales. A pesar de haber protagonizado la campaña electoral y de referenciarse con el nuevo gobierno peronista, siempre tuvieron que lidiar con sus resquemores de lo que llamaban -no sin cierta subestimación- como las instancias político-formales de la “democracia burguesa". Por esta razón, en un principio habían criticado a los comicios como una "trampa" y tenían un discurso confrontativo con otros sectores del movimiento que pretendían borrar su contenido revolucionario e "integrarlo" al sistema ${ }^{321}$.

Más allá de esta ambivalencia de Montoneros y la JP Regionales, la JUP era un frente de masas y desde allí daba centralidad a su trabajo en el ámbito universitario. A lo que se sumaba que recibía con ansias al gobierno electo por el nuevo panorama que podría abrirse en la universidad. Esto no era una cuestión exclusiva de los sectores peronistas, hasta descendientes de la antigua izquierda y el reformismo recibieron a Cámpora con expectativas. Al poco tiempo de las elecciones presidenciales, se realizó el Congreso de Unidad Metropolitana para dirimir las autoridades de la Federación Universitaria de Buenos Aires (FUBA). El encuentro logró la participación de los dos sectores en que estaba dividida la Federación Universitaria Argentina (FUA) desde noviembre de 1970. La FUA La Plata se encontraba en manos del Movimiento de Orientación Reformista (MOR), la agrupación estudiantil que respondía al PC; mientras que la FUA Córdoba era conducida por Franja Morada (FM) y el Movimiento Nacional Reformista (MNR), enrolado en el Partido Socialista Popular (PSP), aunque también participaban en ella vertientes de izquierda como la

\footnotetext{
${ }^{320}$ JUP, "El peronismo en la universidad", abril 1973. Reproducido en Aportes para la nueva universidad, Secretaría de Planeamiento, UNPBA, No 1, julio de 1973, pp. 26-27.

${ }^{321}$ Un análisis de las tensiones que cruzaron a Montoneros y al conjunto de la Tendencia frente a la apertura electoral, puede consultarse en: Lenci, M. L., Ob. cit., 1999, pp. 200-201. Por otra parte, este tema era reconocido contemporáneamente por propios integrantes de la JP Regionales y Montoneros. El 28 de abril, Nicolás Casullo escribió una nota en La Opinión, donde reconocía que la JP Regionales había acertado en su defensa al retorno de Perón y a la candidatura de Cámpora, pero su política de no afiliación al partido la condujo a no tener gran gravitación en la conformación de listas electorales cuando finalmente quisieron integrarlas. "La composición de la JP determina sus propuestas radicalizadas", en La Opinión, 28 de abril 1973.
} 
Tendencia Estudiantil por la Revolución Socialista (TERS), el Frente de Agrupaciones Universitarias de Izquierda (FAUDI), la Tendencia de Agrupaciones Revolucionarias Estudiantiles de Avanzada (TAREA), las Agrupaciones Universitarias Nacionales (AUN) y la Tendencia Universitaria Popular Antiimperialista Combativa (TUPAC) ${ }^{322}$. Las jornadas llevadas a cabo entre el 5 y el 6 de mayo terminaron en la elección de una conducción que respondía al MOR, con Norberto Castagni como presidente y Ricardo López como secretario general. Si bien las distintas agrupaciones que formaron parte del encuentro tenían diferencias en la valoración del nuevo gobierno peronista a punto de asumir, la FUBA declaró un "apoyo crítico" a las flamantes autoridades en un petitorio que reclamaba la liberación de los presos políticos, el fin del "continuismo" en la universidad, la participación estudiantil en el cogobierno y la reanudación de los vínculos diplomáticos con $\mathrm{Cuba}^{323}$.

Desde ya que el respaldo crítico al gobierno electo que emitía la declaración final de la federación porteña era más cercana a la línea política general de su conducción comunista. A pesar de que el PC no había formado parte del FREJULI y sus candidatos habían integrado la Alianza Popular Revolucionaria (APR), que encabezaron Oscar Alende y Horacio Sueldo, recibió con mayores expectativas que otros grupos de izquierda el nuevo panorama político $^{324}$. Otros sectores como el PCR y Política Obrera, en los que se referenciaban el FAUDI y la TERS, habían llamado al voto en blanco y a no participar de lo que consideraban un "fraude electoral",325.

\section{IV - La ASunción de Puiggrós en la UBA}

Teniendo en cuenta estos últimos posicionamientos, en una nota para el diario $L a$ Opinión escrita unos días antes del congreso de la FUBA, Portantiero llamaba al conjunto de la izquierda a reacomodar sus esquemas ante la nueva situación política. A su entender, los sectores vinculados a la JP Regionales y Montoneros estaban demostrando ser algo más que un mero entusiasmo juvenil y parecían delinear una tendencia política con un programa

\footnotetext{
${ }^{322}$ El FAUDI era el brazo estudiantil del Partido Comunista Revolucionario (PCR); TAREA estaba bajo la égida del Partido Socialista de los Trabajadores (PST); TERS era el grupo universitario del colectivo trotskista Política Obrera; AUN pertenecía al Partido Socialista de la Izquierda Nacional (PSIN); mientras TUPAC estaba vinculada a Vanguardia Comunista.

323 "Efectuará la FUBA un congreso de unidad", en La Nación, 5 de mayo 1973; "El congreso de la FUBA. Concretaron la unidad fuerzas antagónicas", en La Nación, 8 de mayo 1973; "El activismo político en la universidad", en La Nación, 12 de mayo 1973.

${ }^{324}$ Gilbert, I., La Fede. Alistándose para la revolución. La Federación Juvenil Comunista 1921-2005, Bs. As., Sudamericana, 2009, pp. 590-591. También puede consultarse: "Replanteó el ENA su actividad frente al nuevo gobierno", en La Opinión, 8 de mayo 1973; "Censura comunista al llamado de Cámpora a la unidad nacional", en La Opinión, 20 de mayo 1973.

325 "El voto en blanco en la izquierda antiparlamentaria", en La Opinión, 3 de marzo 1973.
} 
nacionalista, revolucionario y socialista ${ }^{326}$. Aunque el integrante de Pasado y Presente, no era la única firma reconocida que encabezaba las notas de opinión del periódico dirigido por Jacobo Timerman. A principios de los setenta, también era usual encontrar en el "Diario independiente de la mañana" a Mariano Grondona, quien ya había participado en Primera Plana con columnas que eran recordadas por su apoyo explícito a la intervención militar de Onganía. Ahora en el año '73 se mostraba como un defensor de la institucionalidad del nuevo gobierno que estaba por asumir. Dos días antes del esperado 25 de mayo, escribió un editorial donde parecía poner paños fríos al clima de algarabía de aquellos que creían ver a Cámpora como un promotor exclusivo de la izquierda peronista. Para el abogado, esas apreciaciones estaban lejos de la realidad. A su entender, el oficialismo entrante se definía así mismo como "un centro que miraba hacia la izquierda sin ser, por eso, de izquierda"327.

A decir verdad, no era desacertada la afirmación de Grondona. En su mensaje de asunción ante la asamblea legislativa, el propio Cámpora reconocía el papel decisivo que había tenido la juventud en el triunfo electoral y el futuro promisorio que le esperaría por ello. Sin embargo, en esa misma alocución hacia suyas las palabras de Perón que llamaban a ese mismo sector a dejar atrás el "exceso de entusiasmo" y avanzar con equilibrio en el camino venidero $^{328}$. Pese a que todavía seguía en primer plano el ardor y la movilización de la izquierda peronista, era evidente que la tonalidad política estaba cambiando y que el tercer gobierno justicialista estaba lejos de darle prioridad exclusiva. Esto quedó de manifiesto en los espacios de poder que le fueron asignados a los sectores vinculados a la Tendencia: contaron con un senador nacional, ocho diputados nacionales, una treintena de provinciales e integraron los equipos de gestión de un conjunto de gobernadores electos, con los que compartían espacios y entablaron buenas relaciones políticas durante la campaña electoral ${ }^{329}$.

Si bien no era una cuota de poder nada desdeñable, donde menos sobresalió su representación fue en el gabinete que conformó Cámpora luego de sus reuniones con Perón en Madrid. En los puestos de primera línea no había ningún hombre de la Tendencia. Lo más cercano era el joven abogado Esteban Righi, antiguo militante reformista porteño que llegó a

\footnotetext{
326 "Fenómenos nuevos obligan a reacomodar esquemas" en La Opinión, 22 de abril 1973.

327 "Se aclara el cuadro de oposiciones y alianzas del eminente gobierno", en La Opinión, 23 de mayo 1973.

328 "Mensaje ante la asamblea legislativa", 25 de mayo 1973, en Cámpora, H., La revolución justicialista, Bs. As., Eudeba, 1973, pp. 187-188.

${ }^{329}$ Alicia Servetto sostiene que la izquierda peronista tuvo cercanía con los siguientes gobernadores electos: Oscar Bidegain de Buenos Aires, Antenor Gauna de Formosa, Ricardo Obregón Cano de Córdoba, Alberto Martínez Baca de Mendoza, Jorge Cepernic de Santa Cruz y Miguel Ragone de Salta. Roberto Perdía, ex dirigente de Montoneros, agrega a la lista al gobierno de San Luis y Misiones, pero no al de Formosa. Posteriormente, una vez destituidos de sus cargos, Bidegain y Obregón Cano se integrarían públicamente a Montoneros. Servetto, A. 73/76. El gobierno peronista contra las 'provincias montoneras', Bs. As., Siglo XXI, 2010, p.15; Perdía, R., Ob. cit., 2013, pp.219-220.
} 
convertirse en Ministro del Interior por su fuerte cercanía al propio presidente, a quien sería un error caracterizar como parte orgánica de la izquierda peronista ${ }^{330}$. Aunque el "Tío" entabló buena relación con los "muchachos", nunca dejó de ser un hombre de las entrañas políticas del justicialismo. De este mismo espacio, provenían los que fueron designados para encabezar la cartera de educación, defensa y justicia. La primera estuvo a cargo de Jorge Taiana, médico personal de Perón que había sido rector de la UBA en $1954^{331}$. Mientras que Ángel Robledo y Antonio Benítez, antiguos legisladores del primer peronismo, asumieron las dos restantes, respectivamente. La nómina ministerial se completaba con un representante de la CGT que había sido colaborador de Vandor, el ex presidente de la Confederación General Económica (CGE), el decano de la Escuela de Ciencia Política y Relaciones Internacionales de la Universidad de Rosario y el secretario privado de Perón. De esta manera, Ricardo Otero asumió en Trabajo, José Gelbard en Hacienda y Finanzas, Juan Carlos Puig en Cancillería y José López Rega en Bienestar Social ${ }^{332}$.

\section{UNA RESPUESTA A UNA UNIVERSIDAD CONVULSIONADA}

La dictadura había dejado como legado una sociedad movilizada y en ese contexto los actores pugnaban por distintos espacios de poder. La Tendencia si bien estuvo lejos de hegemonizar el reparto de cargos políticos a nivel nacional y provincial, lograría fortalecerse en el ámbito educativo más importante del país con la designación de un rector interventor que respondía a sus lineamientos ideológicos. Este nombramiento no ocurría en el vacío y en gran parte era una respuesta a la agitada situación política que vivía la UBA. Desde varios días antes de la asunción de Cámpora, militantes universitarios del peronismo y la izquierda habían realizado una serie de protestas para exigir la renuncia de funcionarios nombrados por el régimen militar. Las más activas fueron realizadas contra el rector y los decanos de Ciencias Exactas y de Filosofía y Letras. Debido a estos rechazos, Carlos Durrieu, Raúl Zardini y Antonio Serrano Redonnet renunciaron a sus cargos antes de la retirada de

\footnotetext{
${ }^{330}$ Bernetti, J., "Righi: la recuperación democrática y el peronismo", en Controversia, № 1, México, 1979.

${ }^{331}$ Cabe resaltar que al interior del Ministerio de Cultura y Educación, le fue asignada a la izquierda peronista la Secretaría de Prensa y el Departamento de Cultura y Comunicación de Masas. La primera quedo a cargo de Andrés Zavala y el segundo de Nicolás Casullo. Ambos habían militado en JAEN y desde ahí se vincularon a la JP Regionales y Montoneros. Para Bartoletti, la agrupación de Galimberti supo estar siempre bien ubicada en términos de influencias y espacios de poder, a pesar de no ser un grupo extenso en términos numéricos. Bartoletti, J., Ob. cit., 2010, p. 415.

332 "Los nuevos ministros", en La Prensa, 26 de mayo 1973. Para una caracterización de los espacios de poder y las áreas de influencia que consiguió la Tendencia durante el gobierno de Cámpora, véase: Bernetti, J., Ob. cit., 2011, pp. 95-100; Svampa, M., "El populismo imposible y sus actores, 1973-1976", en James, D. (comp.), Violencia, proscripción y autoritarismo (1944-1976), Bs. As., Sudamericana, 2003, pp. 397-402; Gillespie, R, "Soldados de Perón: historia crítica sobre los Montoneros", Bs. As., Sudamericana, 2008, pp. 211-217.
} 
Lanusse $^{333}$. Sin embargo, los altercados continuaron en medio de las "tomas" de reparticiones públicas que se desataron luego de que Cámpora recibiera la banda presidencial el 25 de mayo. Estas involucraron a grupos de distinto signo político y cada una de ellas tuvo sus propias particularidades. Todas juntas tuvieron tanto alcance y duración que el propio Abal Medina en su figura de secretario general del MNJ tendría que pedir al mes siguiente en cadena nacional el cese de las mismas ${ }^{334}$.

Aunque en el caso de la UBA, las ocupaciones no se extendieron tanto y estuvieron acotadas a la asunción de las nuevas autoridades que se realizaron al poco tiempo de la jura presidencial. Cuando empezó a correr el rumor de una intervención de las universidades nacionales, el 28 de mayo a la mañana los no docentes enrolados en la Asociación del Personal Universitario de Buenos Aires (APUBA) tomaron los edificios del rectorado y las facultades porteñas. Su argumento era que debían ser los trabajadores lo que entregaran las instalaciones a los flamantes mandatarios y que era necesario garantizar que los funcionarios salientes no innovaran en materia administrativa, como supuestamente pretendían hacerlo mediante una resolución que disponía una partida de 1.300 millones de pesos para abonar retroactividades de incrementos salariales de personal jerarquizado. A la medida de fuerza iniciada por los no docentes, se sumó la JUP, quien ya venía reclamando el fin del “continuismo" junto a otras agrupaciones estudiantiles ${ }^{335}$. Finalmente, el 29 de mayo Cámpora decretó la intervención de las universidades nacionales y designó a Rodolfo Puiggrós en el cargo de rector interventor de la casa de estudio porteña ${ }^{336}$. Al día siguiente, el flamante funcionario concurrió junto al ministro Taiana al rectorado, donde el secretario

\footnotetext{
${ }^{333}$ Para un panorama de las protestas contra el "continuismo" con anterioridad al 25 de mayo, puede consultarte: La Opinión, 4, 6, 16, 18, 23, 25 de mayo 1973; La Prensa 18 y 19 mayo 1973; La Nación 18, 23, 24 de mayo 1973.

${ }^{334}$ El 14 de junio de 1973, Abal Medina pidió el levantamiento de las ocupaciones. Entre mayo y julio de ese año se produjeron "tomas" generalizadas en instituciones públicas y privadas de distintos lugares del país, como radioemisoras, hospitales, comercios, industrias, oficinas, hoteles, universidades, escuelas primarias y secundarias. Este proceso requiere un análisis en sí mismo ya que fue una experiencia compleja donde participaron orientaciones políticas de izquierda y derecha. Véase: Nievas, F., "Cámpora: primavera-otoño. Las tomas", en Pucciarelli, A. (ed.), La primacía de la política, Bs. As., Eudeba, 1999; Nievas, F., "Del Devotazo a Ezeiza. Guerra de posiciones en junio de 1973", en Izaguirre, I. (coord.), Lucha de clases, guerra civil y genocidio en Argentina 1973-1983, Bs. As., Eudeba, 2009.

335 Para una reconstrucción de las ocupaciones en la UBA previas a su intervención, véase: "Los no docentes ocuparon ayer la Universidad local", en La prensa, 29 mayo 1973; "Ocuparon dependencias de la Universidad", en La Nación, 29 de mayo 1973; "Fueron ocupadas por peronistas todas las facultades de Buenos Aires y La Plata”, en La Opinión, 29 de mayo 1973; "Cámpora decretó la intervención a las universidades nacionales”, en La Opinión, 30 mayo 1973.

${ }^{336}$ Por el decreto 37 del 29 de mayo de 1973 se designaron las autoridades de las Universidades Nacionales que habían sido intervenidas por el decreto 35 del mismo día. Los interventores contaban con las atribuciones que los estatutos otorgan al rector y al Consejo Superior. Decreto № 35, Bs. As., 29/05/1973, en Boletín Oficial de la República Argentina, No 22705, Año LXXXI, viernes 13 de julio 1973; Decreto No 37, Bs. As., 29/05/1973, en Boletín Oficial de la República Argentina, № 22.684, Año LXXXI, lunes 11 de junio 1973.
} 
general de APUBA, Antonio Martínez, les entregó las llaves del edificio como símbolo de que la toma llegaba a su fin ${ }^{337}$.

La designación de Puiggrós era todo un símbolo de la época. Un intelectual que se había distanciado del PC cuando éste decidió formar parte de la Unión Democrática en 1945 y que había dedicado buena parte de su obra a la crítica de las izquierdas argentinas por su falta de comprensión de la realidad nacional, ahora se convertía en rector interventor de una universidad donde militaban muchos jóvenes que habían dejado atrás el viejo antiperonismo de sus padres ${ }^{338}$. La misma asunción de su cargo el 30 de mayo era sintomática al respecto. No sólo porque durante ella aparecieron ribetes de la liturgia justicialista como el himno, la marcha peronista y el minuto de silencio por Eva Perón, sino porque también se hicieron visibles los símbolos, los actores y los cambios que habían traído los dieciocho años de proscripción. Entre medio de banderas montoneras y gritos por los guerrilleros caídos, Taiana investía a Puiggrós en presencia de dirigentes de la JUP, la FUBA y FUA La Plata. Desde ya

${ }^{337}$ Una amplia cobertura de la asunción de Puiggrós, puede encontrarse en: "La intervención en la Universidad", en La Nación, 31 de mayo 1973; "Fue puesto en funciones el nuevo interventor universitario", La Prensa, 31 de mayo 1973. En relación al proceso más amplio de ocupaciones de reparticiones públicas, debe tenerse en cuenta que la toma de APUBA encontró el repudio de la Asociación de Trabajadores del Estado (ATE), la cual acusaba a la primera por su identificación con núcleos estudiantiles de "ideologías izquierdistas". Véase: "Prosigue el pleito en la Universidad Porteña", en Clarín, 30 de mayo 1973. También que al contrario de lo sucedido en la UBA, en otros espacios dependientes del Ministerio de Cultura y Educación se sumaron a la escalada de ocupaciones sectores ligados a la derecha peronista. Nievas, F., Las tomas durante el gobierno de Cámpora, Tesis de Maestría, FSOC, UBA, 1999.

${ }^{338}$ Puiggrós puede ser definido como intelectual, historiador, periodista y profesor universitario. En 1928 se acercó al PC y fue expulsado luego del XI Congreso de 1946 por su adhesión al peronismo. Entre los años cuarenta y cincuenta, fue el principal teórico de la disidencia comunista del Movimiento Pro Congreso Extraordinario y el Movimiento Obrero Comunista (MOC). En 1956 publicó la primera versión de su obra más trascendente: Historia crítica de los partidos políticos argentinos, donde desarrolló una fuerte crítica a la izquierda argentina por su incomprensión del peronismo. Tras un paso por México, donde se desempeñó como periodista y profesor de la UNAM, volvió en 1966 a la Argentina. Ese año constituyó el "Club Argentina 66". Según Acha, tenía el fin de elaborar una teoría que hegemonizara al movimiento peronista para inyectarle un impulso revolucionario. En 1969 publicó el quinto volumen de la Historia crítica de los partidos políticos argentinos, bajo el título El peronismo: sus causas. Allí sostuvo que ese movimiento policlasista necesitaba una teoría revolucionaria para orientar las tareas de liberación nacional, pero también profundizar una etapa posterior de revolución social. El mismo Perón prologó la segunda edición de este volumen en 1971. Al año siguiente, Puiggrós se afilió al PJ. Según Miguel Bonasso, Montoneros presentó una terna de candidatos para ocupar el cargo de interventor de la UBA en 1973, donde figuraban él, Hernández Arregui y Lucio Gera. Algunos testimonios recogidos en esta tesis abalan la cuestión de la terna. Por otra parte, Taiana escribió en sus memorias que el nombramiento de Puiggrós fue la única solicitud que Perón le hizo a Cámpora. Más allá de estas visiones particulares, en este trabajo hacemos hincapié en que habría sido muy difícil la designación de otro perfil en la UBA, dada la capacidad de movilización y el signo político de los actores universitarios. Georgieff sostiene que en los sesenta y setenta, Puiggrós fue el intelectual más destacado de un nacionalismo popular revolucionario ligado a la izquierda peronista debido a que trabajó sistemáticamente la vinculación de la cuestión nacional con la revolución y fue un referente para las jóvenes generaciones. Véase: Acha, O., La Nación Futura. Rodolfo Puiggrós en las encrucijadas argentina del siglo XX, Bs. As, Eudeba, 2006, p. 208; Bonasso, M., Diario de un clandestino. Bs. As., Planeta, 2000, pp. 116-119; Taiana, J., El último Perón. Testimonio de su médico y amigo, Bs. As., Planeta, 2000, p. 96; Georgieff, G., Nación y revolución. Itinerarios de una controversia en Argentina (1960-1970), Bs. As., Prometeo, 2008, p.89. Además, sobre la biografía político-intelectual de Puiggrós puede consultarse: Puiggrós, A., Rodolfo Puiggrós. Retrato familiar de un intelectual militante, Bs. As., Taurus, 2010; Friedemann, S., El marxismo peronista de Rodolfo Puiggrós. Una aproximación a la izquierda nacional, UBA, IIGG, Documento de jóvenes investigadores, No 39, 2014. 
que no estaban todos los grupos estudiantiles, el FEN - OUP sentía que ese era un acto de la Tendencia y otros sectores de izquierda no pensaban en los mismos términos que la conducción comunista de las dos federaciones. Pero la designación de Puiggrós era funcional a un ámbito donde crecía el peronismo de izquierda y más de un descendiente del viejo reformismo estaba dispuesto a brindar un apoyo crítico al gobierno. Por esta razón, no era casual que el flamante interventor llamara en su primer discurso a recibir el apoyo no sólo de peronistas, sino de todos los que compartían la idea de liberación nacional y pretendían seguir el "camino socialista" que el "país había elegido". Asimismo reivindicaba el liderazgo de Perón y convocaba hacer efectiva la "alianza obrero-estudiantil" que muchos habían proclamado desde la Reforma, pero nunca nadie había realizado ${ }^{339}$.

Luego de la asunción de Puiggrós, la centenaria institución fue rebautizada de hecho como la "Universidad Nacional y Popular de Buenos Aires" (UNPBA) ${ }^{340}$. La primera tarea que encaró el nuevo funcionario fue nombrar a los cargos más importantes de la UNPBA y a los delegados interventores de cada facultad. Entre los primeros, designó a Ernesto Villanueva como secretario general, a Jorge Capio como secretario de planeamiento ${ }^{341}$ y a Rogelio García Lupo como director ejecutivo de la Editorial Universitaria de Buenos Aires (EUDEBA), a la que luego se sumó Arturo Jauretche como presidente ${ }^{342}$. Mientras que en las casas de estudio, asumieron Justino O’Farrell en Filosofía y Letras, Oscar Sbarra Mitre en Ciencias Económicas, Alberto Banfi en Odontología, Alfredo Ibarlucía en Arquitectura y Urbanismo, Francisco Rossi en Veterinarias, Miguel Virasoro en Exactas y Naturales, Marcelo Cereijido en Farmacia y Bioquímica, Horacio Pericoli en Agronomía, Mario Kestelboim en Derecho y Ciencias Sociales, Teseo Roscardi en Ingeniería y Tomás Mascitti en Medicina ${ }^{343}$. Estos dos últimos renunciaron a los pocos días y en su lugar ocuparon el cargo de delgados interventores Enrique Martínez y Mario Testa ${ }^{344}$. A lo que sumó, el nombramiento como rector del CNBA a Raúl Aragón y de la Escuela Superior de Comercio Carlos Pellegrini a

\footnotetext{
${ }^{339}$ Por el acto de investidura de Puiggrós, véase documentos referenciados en la cita 337. En este punto, tampoco puede pasarse por alto que la dirección de la FUBA fue recibida por Puiggrós al otro día de su asunción. "La intervención en la Universidad", en La Nación, 31 de mayo 1973.

${ }^{340}$ No existió una normativa por el cambio de nominación, sino que fue impuesta por los protagonistas al momento de asumir las nuevas autoridades. La misma se reflejó luego en las resoluciones, publicaciones, solicitadas y documentos que empezó a emitir la UBA con posterioridad a la designación de Puiggrós.

${ }^{341}$ El primer cargo de Villanueva fue de secretario académico. Después cambió el organigrama del rectorado y pasó a ser secretario general, instancia de la cual dependía la secretaria de planeamiento donde fue designado Carpio, además de otras secretarías que componían la estructura del rectorado. Res. (C.S.) No 10, UBA, 6 de junio 1973.

${ }^{342}$ La primera resolución que dictó la gestión de Puiggrós dispuso la intervención de EUDEBA y la designación de García Lupo. Res. (C.S.) N ${ }^{\circ}$ 1, UBA, 31 de mayo 1973. El cargo de Arturo Jauretche como presidente es ratificado por Res. (C.S.) No 47, UBA, 14 de enero 1974.

${ }^{343}$ Res. (C.S.) $\mathrm{N}^{\circ} 2$ y No 3 , UBA, 31 de mayo 1973; Res. (C.S.) $\mathrm{N}^{\circ} 5$ y N $\mathrm{N}^{\mathrm{o}}$ 7, UBA, 1 de junio 1973.

${ }^{344}$ Res. (C.S.) No 9, UBA, 5 de junio 1973 y Res. (C.S.) No 40 y No 41, UBA, 19 junio 1973.
} 
Ramón Vilutis ${ }^{345}$.

\section{V - UNIVERSITARIOS PERONISTAS CON PUIGgRós}

Cuando anteriormente afirmamos que la izquierda peronista lograría fortalecerse en el ámbito educativo más importante del país con la designación de Puiggrós, no era sólo porque él había sido un referente político-intelectual de muchos jóvenes que se acercaron al peronismo en los años sesenta o porque en su acto de asunción se coreaba la consigna de socialismo nacional. Lo relevante en esta cuestión fue que muchos espacios de gestión durante su rectorado fueron ocupados por docentes, intelectuales y profesionales que formaban parte de los frentes de masas de la JP Regionales o estaban inscriptos en agrupamientos que tenían vinculaciones con ella o con las mismas organizaciones armadas. Si bien puede profundizarse el análisis de lo ocurrido en cada casa de estudio, un panorama general por dichos grupos brinda elementos para comprender el rumbo seguido por las experiencias de peronización a principio de los setenta y los ámbitos que encauzaron la actividad política y profesional de los universitarios en este nuevo contexto. Por tal razón, en los siguientes subapartados nos abocamos a identificar de dónde provenían los docentes e intelectuales en los que se apoyó Puiggrós en el rectorado de la UNPBA, aunque la experiencia de su gestión será abordada en el quinto capítulo ${ }^{346}$.

\section{Los Equipos Político-TÉcnicos Y LA Agrupación Docente Universitaria Peronista}

Los Equipos Político-Técnicos (EPT) dependían directamente de la JP Regionales. Fueron organizados en 1972 y su constitución oficial se anunció en abril de 1973 mediante una conferencia de prensa y un acto en el sindicato de Luz y Fuerza, a sólo unos días del lanzamiento de la JUP ${ }^{347}$. Durante su inauguración, Alcira Argumedo leyó un documento donde señalaba que el objetivo a corto plazo de los EPT era generar cuadros y proyectos

\footnotetext{
${ }^{345}$ Res. (C.S.) No 4, UBA, 1 de junio 1973 y Res. (C.S.) No 8, UBA, 5 de junio 1973.

${ }^{346}$ En la tesis doctoral de Friedemann se puede encontrar un análisis de las designaciones de Puiggrós en el rectorado de la UBA y una aproximación a los equipos de gestión de cada facultad porteña. Si bien esta investigación parte de un enfoque analítico distinto, dicho trabajo es un gran aporte para reconstruir la experiencia de la UNPBA como la trayectoria de sus funcionarios. Friedemann, S., La Universidad Nacional y Popular de Buenos Aires (1973-1974). Una reforma universitaria inconclusa, Tesis de Doctorado, FSOC, UBA, 2015.

${ }^{347}$ En relación a la conferencia de prensa del día 24 y el acto de lanzamiento público del día 26, véase: “Creará la juventud peronista su propio equipo técnico-político", en La Opinión, 24 de abril 1973; "Concretó un proyecto la juventud peronista", en La Nación, 25 de abril 1973; "Proyectos de los seis equipos técnicos-políticos", en La Opinión, 28 de abril 1973. Para una descripción del proceso de surgimiento de los EPT, puede consultarse: Pozzoni, M., "La participación político-técnica de la izquierda peronista en el ministerio de educación bonaerense (1973-1974)", en Estudios, $\mathrm{N}^{\circ}$ 8, julio-diciembre 2015.
} 
políticos para el gobierno electo. A su entender, esta tarea coyuntural tenía que seguir profundizando el acercamiento de profesionales al peronismo y terminar de desmitificar el aspecto neutral de la ciencia, como lo habían hecho en años anteriores las Cátedras Nacionales $(\mathrm{CN})^{348}$. Argumedo era integrante del área de educación de los EPT, al igual que Juan Pablo Franco. Este último, en la misma presentación de abril, afirmaba que los EPT tenían el objetivo de generar políticas para la universidad junto con la Agrupación Docente Universitaria Peronista (ADUP), la cual se había constituido por entonces como un equivalente de la JUP pero enfocada a la organización de graduados y profesores ${ }^{349}$.

En este sentido, los EPT y ADUP sirvieron para aglutinar a los sectores docentes que se referenciaban con la JP Regionales y Montoneros. Algunos de los universitarios que formaron parte de ellos ya tenían acumulada una trayectoria militante y académica previa. No era casualidad que en el lanzamiento de los EPT se hubiese nombrado como antecedente a las CN. De esta experiencia, provenían varios de los que pasaron a ocupar ámbitos clave de gestión con la llegada de Puiggrós, como Villanueva que era su segundo en el rectorado, Carpio que tenía a su cargo la secretaría de planeamiento y O'Farrell en su papel de delegado interventor de Filosofía y Letras. Éste, a su vez, designó a otros ex CN en puestos importantes en esa casa de estudio: Ricardo Sidicaro en la secretaría académica, Guillermo Gutiérrez como director del Departamento de Antropología, Franco en el de Sociología y Fernando Álvarez en el Instituto de esa misma carrera ${ }^{350}$. Sin un pasado en las $\mathrm{CN}$, pero siendo integrante de los EPT y ADUP, Adriana Puiggrós fue nombrada como directora del Departamento de Ciencias de la Educación. Si bien ella se incorporó al espacio de la JP Regionales de la mano del MRP, en sus primeros tiempos universitarios había militado en el Partido Socialista de la Izquierda Nacional (PSIN) de Abelardo Ramos ${ }^{351}$. Por otra parte, O’Farrell también nombró en el Departamento de Filosofía a Conrado Eggers Lan y en Letras al escritor y militante de las FAR Francisco Urondo, quien recientemente había sido liberado

\footnotetext{
348 “Concretó un proyecto la juventud peronista”, en La Nación, 25 de abril 1973

${ }^{349}$ Proyectos de los seis equipos técnico-políticos", en La Opinión, 28 de abril 1973.

350 Entrevista a Ernesto Villanueva, Florencio Varela, 04/05/2014 y 17/09/2014; Entrevista a Jorge Carpio, C.A.B.A., 20/11/2015 y 30/10/2015; Entrevista a Juan Pablo Franco, C.A.B.A., 18/10/2016; Entrevista virtual a Guillermo Gutiérrez, 29/11/2016.

${ }^{351}$ Hacia fines de 1972, el MRP terminó casi en su totalidad absorbido por la JP Regionales y Montoneros. Según Ragali, en la primera mitad de los sesenta, Adriana Puiggrós formó parte del Frente de Acción Universitaria de Ernesto Laclau, el cual se integró al PSIN. Regali, E. A., Abelardo Ramos. La izquierda nacional y la nación latinoamericana, Córdoba, Ferreyra Editor/Ediciones del Corredor Austral/CICUSS, 2012, pp. 313-314. También pueden encontrase varias referencias a la agrupación de Laclau en Tortti, M. C., El viejo partido socialista y los orígenes de la nueva izquierda, Bs. As., Prometeo, 2009, p. 308. Para una trayectoria de Adriana Puiggrós, véase: Entrevista a Adriana Puiggrós, C.A.B.A., 09/02/2016; Camou, A., y Prati, M., "La planificación no es contraria a la democracia: donde hay desigualdad hay que planificar", en Cuestiones de Sociología, № 8, 2012.
} 
de la cárcel de Villa Devoto junto a otros presos políticos de la dictadura.

En el área de salud de los EPT participó Testa, el sanitarista que asumió la intervención de Medicina luego de la inmediata renuncia de Mascitti. Testa había vuelto recientemente al país, luego de una experiencia de posgrado en la Universidad Central de Venezuela, vinculada a la planificación de políticas de salud. Un tiempo antes de su partida había trabajado como Responsable de Bienestar Estudiantil en la UBA durante el rectorado de Risieri Frondizi ${ }^{352}$. Por otra parte, en el área de vivienda y de economía estuvieron Ibarlucía y Sbarra Mitre, luego interventores de Arquitectura y Ciencias Económicas, respectivamente ${ }^{353}$. A su vez, en los EPT o en ADUP también participaron graduados recientes que habían sido hasta hace poco tiempo militantes estudiantiles y luego pasaron a ocupar espacios de gestión. Uno de ellos fue Horacio Fazio, el secretario académico del decanato de Sbarra Mitre. De origen cristiano, había participado a fines de los sesenta en los Grupos Marcha con Bárbaro, Habbeger, De Gregorio y Mendizábal. Luego de una estadía de formación en la Universidad de Madrid volvió a la Argentina y siguió su militancia en la Organización Peronista 17 de Octubre (OP-17) y en los CEP de Económicas, donde participó hasta su graduación ${ }^{354}$. Otra caso similar fue el de Roberto Marafioti, designado por O'Farrell como secretario de extensión en su decanato; poco tiempo antes de graduase en la carrera de Letras había militado en FANDEP ${ }^{355}$. Finalmente, podemos nombrar a Ernesto López, quien de CENAP pasó a ADUP luego de graduarse en sociología; integró el Instituto del Tercer Mundo creado una vez asumido Puiggrós, donde ex CN ocuparon puestos importantes, como Argumedo en la dirección del centro de estudios y Gunnar Olsson del centro de investigaciones ${ }^{356}$.

\section{Consejo Tecnológico del Movimiento Nacional Justicialista}

El CT del MNJ fue otro espacio importante que sirvió como base a la gestión de

\footnotetext{
352 En 1958 comenzó a trabajar en la gestión de Frondizi y en la década del sesenta partió a Venezuela con una beca otorgada por el gobierno de ese país. Allí participó en la creación del método de planificación en salud conocido como "Método CENDES OPS". Posteriormente trabajó en su difusión dando cursos y seminarios para OPS en América Latina. Entrevista a Mario Testa, C.A.B.A., 16/02/2016. También puede consultarse el "Fondo Mario Testa" de la Universidad Nacional de Lanús: http://www.unla.edu.ar/index.php/fondo-mario-testa. En la presentación de los EPT en 1973 declaró: “Ante la destrucción sistemática del hospital público, buscaremos que los propios núcleos villeros y barriales se hagan cargo de la infraestructura de salud. Hay salud para el pueblo o no hay salud para nadie. "Proyectos de los seis equipos técnicos-políticos", en La Opinión, 28 de abril 1973.

353 "Creará la juventud peronista su propio equipo técnico-político", en La Opinión, 24 de abril 1973. Según Bonasso, quien fue encargado del área de comunicación de los EPT, en el organigrama que Montoneros le elevó a Perón, Sbarra Mitre figuraba como candidato a ministro de Hacienda y Finanzas y también, en evidente premio consuelo, a subsecretario de Comercio Exterior. Bonasso, M., Diario de un clandestino, Bs. As., Planeta, 2000, p. 118.

${ }^{354}$ Entrevista a Horacio Fazio, C.A.B.A., 09/12/2015.

${ }^{355}$ Entrevista a Roberto Marafioti, C.A.B.A., 06/01/2016 y 19/01/2016.

${ }^{356}$ Entrevista a Ernesto López, C.A.B.A., 18/05/2016. El Instituto del Tercer Mundo fue creado mediante la Res. (C.S.) $\mathrm{N}^{\circ}$ 347, UBA, 30 de agosto 1973.
} 
Puiggrós. Si bien no era parte de la estructura orgánica de la JP Regionales, compartía el ideario de la izquierda peronista. La iniciativa del CT surgió a principios de los setenta cuando Perón convocó a Madrid a Rolando García, doctor en Física y docente universitario que había sido cofundador de la Universidad Nacional del Sur en 1956, el primer vicepresidente del CONICET y decano de la Facultad de Ciencias Exactas y Naturales de la UBA entre 1957 y 1966. Este encuentro llamó a muchos la atención, dado que García había sido uno de los referentes de la universidad reformista que siguió al derrocamiento del peronismo y que se desarrolló en contraposición a él. Luego del encuentro en España, García se convirtió en el presidente del CT, finalmente constituido el 14 de julio de $1972^{357}$.

Al igual que los EPT, este organismo fue conformado con la idea de funcionar como una usina de cuadros y políticas públicas. Con este objetivo, en 1973 editó las Bases para un programa peronista de acción de gobierno y Gobierno Peronista, dos publicaciones que contenían un conjunto de documentos y propuestas en industria, energía, universidad, salud, vivienda, comunicación, transporte y energía, entre muchas otras áreas ${ }^{358}$. Como integrante del amplio conglomerado de la Tendencia que reivindicaba el objetivo del socialismo nacional, el CT se diferenciaba de agrupamientos del mismo estilo formados a principios de los setenta por otros sectores del movimiento, como el Comando Tecnológico Peronista que conducía Licastro o el Consejo de Planificación encabezado por el abogado Leopoldo Frenkel, que respondía a Antonio Cafiero y Alfredo Gómez Morales ${ }^{359}$.

Luego de la asunción presidencial de Cámpora en mayo de 1973, varios integrantes del CT ocuparon cargos importantes en las universidades nacionales y en ministerios de la provincia de Buenos Aires. Entre los primeros, estaba el ingeniero Iván Chambouleyron, con un pasado reformista en la UNLP y un doctorado en física en la Universidad de París, ese año fue designado interventor de la Universidad Tecnológica Nacional (UTN) al poco tiempo de

\footnotetext{
357 "El Consejo Tecnológico del Movimiento Nacional Justicialista", en Ciencia Nueva, N 18,18 de agosto 1972. Para una rememoración actual de García por un ex integrante del CT, véase: Bauer, Horacio W., "Un maestro de la militancia y la ciencia”, en Página 12, 14 de diciembre 2012. Más adelante, el 20 de abril de 1977, Puiggrós ingresaría al Movimiento Peronista Montonero como secretario de la Rama de Intelectuales, Profesionales y Artistas en la que también se integraría García. Acha, O., Ob. cit., 2006, p. 269.

${ }^{358}$ Las publicaciones pueden considerarse como una porque el tono, el diseño y la forma se mantienen en ambas aunque cambien de nombre. En ellas, el organismo se presentaba de esta manera: "El CT del MNJ es uno de los órganos oficiales del Movimiento que tiene a su cargo la formulación de propuestas para planes de gobierno". Véase, por ejemplo: Bases para un programa peronista de acción de gobierno, $\mathrm{N}^{\circ} 2,10$ de mayo 1973. Pueden encontrarse distintos números de las dos publicaciones en: www.ruinasdigitales.com.

${ }^{359}$ En este punto, es importante aclarar lo señalado al principio de este capítulo. Existían sectores que eran parte de la Tendencia, pero no de la estructura orgánica de Montoneros y la JP Regionales, el tándem hegemónico de la izquierda peronista. Para visualizar los distintos grupos del peronismo que proponían la formación de cuadros y políticas al nuevo gobierno, puede consultarse: "Rolando García propone crear un ministerio de Ciencia y Técnica", en La Opinión, 24 de marzo 1973; "El Comando Tecnológico Peronista hizo conocer su propuesta sobre salud pública. Busca diferenciarse de las otras tendencias justicialistas”, en La Opinión, 28 de abril 1973.
} 
la asunción de Puiggrós ${ }^{360}$. Otro fue Enrique Martínez, quien reemplazó a Roscardi en la Facultad de Ingeniería como delegado interventor a tan sólo unos días de su designación ${ }^{361}$. Martínez se había graduado como ingeniero químico en 1966 y era docente concursado de esa casa de estudio desde antes de 1973. En la primera mitad de los sesenta, había militado en la facultad vinculado a sectores de la primera $\mathrm{JUP}^{362}$. En su gestión como interventor en Ingeniería contó un tiempo con el asesoramiento del mismo García, quien en ese momento era responsable de la Asesoría Provincial de Desarrollo de Buenos Aires ${ }^{363}$. Por otra parte, también fue nombrado Marcelino Cereijido como interventor en la Facultad de Farmacia y Bioquímica, por pertenecer a la red de contactos de García. Cereijido era médico y doctor en fisiología. Se había formado con Bernardo Houssay, premio nobel de físiología y medicina en los años del primer peronismo y declarado opositor al mismo ${ }^{364}$. Sin embargo, permaneció menos de tres meses como decano y fue reemplazado por Raúl Laguzzi, quien estaba referenciado con ADUP y la JP Regionales ${ }^{365}$.

\section{Agrupación de Abogados Peronistas}

\footnotetext{
${ }^{360}$ Entrevista a Iván Chambouleyron, C.A.B.A., 09/05/2016. Es insoslayable su libro autobiográfico por sus referencias a la trayectoria de García y al surgimiento del CT, además de su reconstrucción de la universidad de aquel entonces. Chambouleyron, I., La Lista, Bs. As., Liber Editores, 2014.

${ }^{361}$ Puiggrós asumió el 30 de mayo y el 5 de junio ya designó a Martínez en reemplazo de Roscardi. Res. (C.S.) $\mathrm{N}^{\circ}$ 9, UBA, 5 de junio 1973. Es importante tener en cuenta que Roscardi era el vicedecano de Ingeniería en 1966 cuando se produjo la intervención de Onganía. Él, al igual que García, habían firmado el comunicado del Consejo Superior de la UBA en defensa de la autonomía y la democracia que nombramos en el primer capítulo. "Declaración de la Universidad de Buenos Aires", 28 de junio 1966. Se puede consultar el documento en: Baschetti, R., Ob. cit., 2016, p. 144.

${ }^{362}$ Entrevista a Enrique Martínez, C.A.B.A., 30/12/2015. Durante el tercer gobierno peronista, Martínez también se desempeñó en la función pública. Estuvo a cargo del Departamento de Evaluación de Proyectos de la Secretaría de Industria y de la Dirección de Importaciones en la Secretaría de Comercio Exterior. Para acercarse a sus reflexiones sobre la universidad en los setenta, véase: Martínez, E., El proyecto universitario. Un aporte desde el peronismo, Bs. As., Ciencia Ediciones, 1975.

${ }^{363}$ Entre mayo y julio de 1973, el gobernador bonaerense electo, Oscar Bidegain, sancionó una serie de decretos para designar a sus funcionarios, rodeándose de varios colaboradores cercanos a la izquierda peronista. Entre ellos, García y los ministros de Bienestar Social, Floreal Ferrara, de Asuntos Agrarios, Guillermo Gallo Mendoza, y de Obras Públicas, Alberto González. Pozzoni, M., Ob. cit., 2015, p. 127.

${ }^{364}$ Para Adriana Puiggrós, Cereijido en los setenta valoraba mucho su formación en la universidad postperonista. Para ilustrarlo, en uno de sus libros destaca lo siguiente: "Convocando a su profesor Eduardo Braun Menéndez, Marcelino Cereijido pronunció en 1973 críticas a la comunidad científica argentina no solamente profundas, sino valientes. De cara a las masas estudiantiles, que tenían el anticientificismo como una de sus banderas, expresó que el cientificismo de las décadas del '50 y '60 no era para tanto. La experiencia trasmitida por Cereijido es que en el pos-peronismo [...] la Facultad de Farmacia y Bioquímica sobresalía como un hervidero científico profesional donde se gestaban los técnicos que necesitaban la salud pública y la industria nacional". Puiggrós, A., El Lugar del Saber, Bs. As., Galerna, 2003, p. 308. También puede consultarse el repaso del propio protagonista por su trayectoria y formación en: Cereijido, M., La nuca de Houssay. La ciencia argentina entre Billiken y el exilio, México, FCE, 2000.

${ }^{365}$ Res. (C.S.) No 350 , UBA, 30 de agosto 1973. Al poco tiempo de su renuncia, la revista Ciencia Nueva publicó una nota de Cereijido con un análisis de situación de la Facultad de Farmacia y Bioquímica que él mismo le entregó a Laguzzi al abandonar su cargo. "No pone el hombro quien no quiere...", en Ciencia Nueva, No 27 , octubre 1973 .
} 
La Agrupación de Abogados Peronistas (AAP) fue otro de los espacios que canalizó la peronización de universitarios a principios de los setenta y que sirvió como punta pié inicial a la gestión de Puiggrós. La AAP surgió en 1972 en el seno de la Asociación Gremial de Abogados (AGA), entidad que había tenido un papel destacado en la defensa de presos políticos de la dictadura y en donde participaron abogados politizados de izquierda y peronistas, los cuales tenían contactos con distintas organizaciones, especialmente con los grupos armados ${ }^{366}$. Por su carácter clandestino, a estas organizaciones les era fundamental contar con profesionales de actuación pública y legal para defender a sus militantes. La AGA nucleó a abogados de distintas procedencias e incluso en 1973 un miembro de su primera comisión directiva, Estaban Righi, llegó a ser designado ministro del interior del gabinete de Cámpora. A diferencia de la AGA, que era un organismo de "frente" o "plural", la AAP optó por poner en primer plano una identificación partidaria. Su “junta de mando" estuvo integrada por Mario Kestelboim, Mario Hernández y Rodolfo Ortega Peña. Los tres fueron nombrados en cargos de gestión una vez ocupado el rectorado por Puiggrós.

Kestelboim asumió como delegado interventor en la Facultad de Derecho, donde se había graduado y dictaba clases. En su época de estudiante, tuvo un breve paso por el Movimiento Universitario Reformista (MUR), pero luego participó en la formación de ANDE en su facultad. También estuvo vinculado al Comando Nacional Peronista $(\mathrm{CNP})^{367}$. Una vez graduado, en la primera mitad de los sesenta, se sumó a la Comisión de Familiares de Detenidos (COFADE), creada unos años antes por Isidoro Ventura Mayoral, el abogado de Perón, como respuesta al Plan CONINTES impulsado por Arturo Frondizi. Al poco tiempo de su ingreso, la COFADE empezó a tener lazos con el MRP de Gustavo Rearte ${ }^{368}$. Luego de estas experiencias, Kestelboim fue un protagonista central de la AGA y de la AAP. De estas agrupaciones provino la mayoría de su equipo, cuando asumió el decanato de Derecho en

\footnotetext{
${ }^{366}$ El hecho que definió la creación de la AGA en 1971 fue el secuestro y desaparición del abogado de izquierda Néstor Martins, junto a la negativa del Colegio de Abogados y la Asociación de Abogados de Buenos Aires de realizar acciones de denuncia sobre el caso. Martins era un abogado ligado al PC que había participado de la Liga Argentina por los Derechos del Hombre y luego se sumó al equipo de defensores de la CGTA. Su desaparición y asesinato está relacionado a que Martins acababa de denunciar y enfrentarse personalmente a un jefe de Coordinación Federal. Muchos de los que trabajaron en el equipo de abogados de la CGTA, impulsaron y formaron parte de la AGA. Chama, M., "Movilización y politización: abogados de Buenos Aires entre 1968 y 1973”, en Pérotin-Dumon, A. (dir.), Historizar el pasado vivo en América Latina, Universidad Alberto Hurtado, 2007.

${ }^{367}$ El CNP fue organizado desde la cárcel por Jhon William Cooke en 1956 y en la Capital Federal tenía como principales referentes a César Marcos y Raúl Lagomarsino. Uno de los principales objetivos políticos del CNP era desplegar una estrategia insurreccional intransigente contra el gobierno militar que permitiese la vuelta de Perón al país. Bozza, A., "La resignificación revolucionaria del peronismo y sus protagonistas durante la etapa de proscripción", en Tortti, M. C., Ob. cit., 2014, p. 65.

${ }^{368}$ Chama, M., "Activismo social, militancia política y radicalización en los años sesenta. La experiencia de la Comisión de Familiares de Detenidos (COFADE)", en Tortti M. C., Ob. cit., 2014, pp. 111-129.
} 
1973: el secretario de Asuntos Estudiantiles Eduardo Pesci, la secretaria de Extensión Universitaria Alicia Pierini, el director del Departamento de Publicaciones Horacio Vega y su subdirector Luis Kon. La única excepción a la regla fue Carlos María Duhalde, el secretario de Supervisión Administrativa ${ }^{369}$. A su vez, Kestelboim también incorporó como colaborador a Envar El Kadri, uno de los fundadores de las FAP, quien fue liberado de presión luego del 25 de mayo de $1973^{370}$. Por otra parte, Raúl Aragón, designado como rector del CNBA, también provenía de la AGA, pero no de la AAP.

Hernández, por su parte, fue secretario académico de la Facultad de Derecho e integró ambos espacios de abogados, desde donde actuó como defensor de militantes acusados por la ejecución del general Aramburu y de algunos de los presos políticos involucrados en la "Masacre de Trelew", el 22 de agosto de 1972. A diferencia de Kestelboim, a comienzos de 1973 su trayectoria ya estaba vinculada a la JP Regionales y a Montoneros, donde participó en distintas áreas. Fue el asesor legal de la JP Regional I de Buenos Aires e incluso el director de los dos primeros números de El Descamisado, el órgano de prensa oficial de Montoneros que lanzó su ejemplar inaugural el 8 de marzo de $1973^{371}$.

Ortega Peña también participó en la AGA y la AAP, al igual que su compañero Eduardo Duhalde. Ambos ocuparon más de un cargo en la gestión de Puiggrós en la UNPBA. El primero como jefe de los departamentos de Historia en la Facultad de Derecho y en Filosofía y Letras. Mientras el segundo como responsable del Instituto de Historia Argentina e Iberoamericana en esta última casa de estudio y de la Subsecretaria de Asuntos Jurídicos del rectorado $^{372}$. Tanto Ortega Peña como Duhalde provenían de familias de clase media

\footnotetext{
${ }^{369}$ Chama, M. y González Canosa, M., "Universidad, política y movimiento estudiantil: la Intervención de Kestelboim y el rol de la Juventud Universitaria Peronista en la Facultad de Derecho de la UBA", en Conflicto Social, No 5, 2011, pp. 313-314.

370 Entrevista a Mario Kestelboim, C.A.B.A., 16/11/2015; Entrevista a Luis Kon, C.A.B.A., 22/12/2015. También puede consultarse un reportaje a Kestelboim y una nota de su autoría de 1973: "El decano de Derecho define pautas de su gestión. Kestelboim consultará a los claustros para modificar los planes de enseñanza", en $L a$ Opinión, 14 de junio 1973; Kestelboim, M., "Una experiencia de militancia: la Asociación Gremial de Abogados", en Peronismo y Socialismo, № 1, 1973.

371 Acerca de Hernández, véase: Baschetti, R., La memoria de los de abajo 1945-2007, La Plata, De la Campana, 2007, Tomo I, pp. 257-258. En los números de El Descamisado nunca figuró su equipo de redacción. La única mención fue a sus directores. Hernández dirigió los número 0 y 1, luego continuó como director Dardo Cabo y como codirector el periodista Ricardo Grassi. La circulación de la revista fue legal en sus 47 números publicados. Montoneros se responsabilizó por su confección y financiamiento. Slipak, D., Las Revistas Montoneras. Cómo la organización construyó su identidad a través de sus publicaciones, Bs. As., Siglo XXI, 2015, p.63. También puede consultarse: Micieli, C., Dar la vida / quitar la vida: el peronismo en los años 70 a través de las publicaciones El Descamisado y El Caudillo, Bs. As., La Parte Maldita, 2010; Nadra, G. y Y., Montoneros: ideología y política en El Descamisado, Bs. As., Corregidor, 2011; Grassi, R., El Descamisado. Periodismo sin aliento, Bs. As., Sudamericana, 2015.

${ }^{372}$ A Duhalde lo designaron subsecretario de asuntos jurídicos de la UNPBA mediante la resolución 11. Ésta transformó la Dirección de Asuntos Jurídicos en una subsecretaría dependiente de la Secretaría Operativa del rectorado. Al poco tiempo de asumir, Puiggrós transformó el organigrama y la estructura interna de la universidad. Véase: Res. (C.S.) No 10 y No 11, UBA, 6 y 7 de junio 1973.
} 
antiperonistas. No obstante, durante sus años de militancia universitaria en Derecho empezaron a recorrer su pasaje al peronismo. Ortega Peña había tenido un efímero acercamiento al radicalismo frondicista, tras lo cual recaló en la FJC hasta 1960. Sin embargo, en paralelo con su militancia comunista, mantuvo intercambios con Juan José Hernández Arregui y César Marcos ${ }^{373}$. Por su parte, Duhalde tras un breve paso por el humanismo, se incorporó al reformismo en el MUR, donde llegó a ser vicepresidente del centro de estudiantes en $1958^{374}$. En el último tramo de su carrera mantuvo contactos con núcleos trotskistas, como Palabra Obrera y Praxis, hasta que a principios de los sesenta se asumirá como peronista por influencia de Hernández Arregui y Ortega Peña, con los cuales participó en la fundación de los Centros Organizados Nacionales de Orientación Revolucionaria (CONDOR) en $1964^{375}$.

Duhalde y Ortega Peña abrieron juntos un estudio jurídico dedicado al derecho laboral y penal a principios de esa misma década, donde establecieron vínculos con distintos sindicatos peronistas, desde uno combativo como la Asociación Obrera Textil de Andrés Framini, hasta la Unión Obrera Metalúrgica de Augusto Timoteo Vandor; gracias a este último vínculo llegaron a ser asesores letrados de la CGT. Luego de esa experiencia, formaron parte de la AGA y de la AAP a inicios de los setenta. En ese momento, tuvo un papel importante Ortega Peña, ya que participó activamente en la campaña "Luche y vuelve" de la JP Regionales, de la comitiva que acompañó a Perón en su primer retorno del 17 de noviembre de 1972 y hasta integró como diputado nacional suplente la lista del FREJULI en las elecciones de marzo del año siguiente ${ }^{376}$. Como veremos en el quinto capítulo, esto le permitirá ser uno de los protagonistas en el debate parlamentario sobre la ley universitaria del tercer gobierno peronista, el cual involucrará a distintos sectores universitarios, entre ellos a la JUP y ADUP.

\footnotetext{
373 Ortega Peña entró en contacto con la Resistencia Peronista a través de Marcos, el dirigente del CNP relacionado a Cooke. Tarcus, H. (dir.), Diccionario biográfico de la izquierda argentina, Bs. As., Emecé, 2007, p. 471 .

374 Entre fines de los cincuenta y comienzos de los sesenta, las agrupaciones estudiantiles construyeron centralmente su identidad en relación al reformismo en la Facultad de Derecho. El MUR era un frente que nucleaba a militantes del PC, PS, Palabra Obrera, MLN, entre otros. Por fuera, se encontraban los humanistas del Movimiento Social Cristiano y los grupos de derecha y extrema derecha como el Movimiento Universitario del Centro, el Movimiento Sindical Universitario y el Sindicato Único de Derecho.

${ }^{375}$ CONDOR nació el 4 de junio de 1964 por iniciativa de Hernández Arregui. Incorporó a intelectuales provenientes del peronismo y la izquierda nacional. Según Acha, su objetivo era trasmitir formación ideológica a la clase obrera y a las capas medias abiertas al proceso de nacionalización desde una perspectiva anclada en el peronismo revolucionario. Acha, O., Historia Crítica de la historiografia argentina. Vol. 1: las izquierdas en el siglo XX, Bs. As., Prometeo, 2009, p. 322.

${ }^{376}$ Celesia, F., y Waisberg, P., La Ley y las armas. Biografia de Rodolfo Ortega Peña, Bs. As., Aguilar, 2013, pp.237-256.
} 


\section{VI - LA PARTIDIZACIÓN DE LA UNIVERSIDAD}

En este capítulo analizamos la manera en que se canalizó organizativamente la peronización de universitarios porteños a inicios de los setenta. Desde el itinerario que recorrimos en los apartados anteriores, podemos delimitar dos procesos importantes que involucraron a diversos actores del ámbito político y académico. Los dos empezaron a constituirse en 1972 y terminaron de plasmarse en 1973.

El primero fue el pasaje de la CUP a la JUP. Como señalamos, esta última organización no surgió espontáneamente luego del triunfo de Cámpora. Al contrario, sus raíces están relacionadas a una experiencia que comenzó a desarrollarse unos años antes, frente al panorama que abrió la retirada del régimen militar. Hacemos referencia a la unificación de los distintos agrupamientos juveniles que impulsó el mismo Perón y en la que tampoco estuvo ausente Montoneros, a través de su articulación con Galimberti; el representante de la JP en el Consejo Superior del MNJ al que le había sido encomendada la tarea. Si bien no pudo materializarse una unidad completa de los distintos grupos, estas articulaciones permitieron el surgimiento de la JP Regionales, de la cual a su vez se desprendieron frentes de masas particulares, entre ellos la JUP. Todo este sector funcionaba en un esquema organizacional bajo la conducción de Montoneros, más allá de que sus militantes no estuvieran necesariamente encuadrados en la estructura armada.

Sin embargo, en el caso particular de la JUP, uno de los espacios de la JP Regionales más activo y movilizado, no puede sostenerse que su surgimiento sólo dependió de un proceso operado de arriba hacia abajo. La agrupación liderada por Ventura también logró materializarse porque tenía tras de sí una nueva militancia universitaria peronista que había comenzado a gestarse a fines de los sesenta y había revitalizado sus lazos a inicios de la década siguiente, acompañando la irrupción de los cuerpos de delgados en la UBA. Este sustrato militante previo fue el que permitió el surgimiento de la CUP en 1972. Aunque la incipiente articulación entre CEP, CENAP, FANDEP y las Bases Peronistas tampoco habría podido dar un salto de unidad más amplio sino hubiese existido la JR Regionales y Montoneros. Salvando las distancias, éstos en cierto sentido cumplieron un papel parecido a la CGTA en años anteriores, al ofrecer un espacio concreto en el que pudieron confluir y fortalecerse los activistas universitarios peronistas. De esta manera, a la JUP se sumó el núcleo de la CUP, pero también formaron parte de ella grupos como FORPE, AEP, entre otros.

Este tipo de politización particular implicó una tensión desde la propia constitución de la JUP. Silvia Sigal sostiene que a partir del régimen de Onganía se produjo una incipiente 
"partidización" de la comunidad académica, cuando comenzaron a florecer organizaciones que dejaron de definirse según la pertenencia a la universidad o la adhesión a la Reforma, para hacerlo en función de una determinada agrupación político-partidaria ${ }^{377}$. El surgimiento de la JUP en la UBA puede mostrarse como un caso paradigmático de dicha hipótesis. Aunque debe aclararse que se trató de una forma específica de partidización, dado que se encauzó en el marco de una estructura a la vez política y militar como la JP Regionales-Montoneros. Esto implicó que la JUP se viera tensionada por dos lógicas que expresó en su discurso de lanzamiento del 23 de abril de 1973. Durante su presentación oficial, se concibió a sí misma como una agrupación enfocada al ámbito concreto del estudiantado y como un espacio para proponer políticas universitarias al presidente electo. Mientras a su vez afirmaba que el "verdadero" cambio llegaría mediante la lucha armada porque la "toma del poder" no se reducía a un simple acto electoral y de gobierno. Como veremos en los capítulos siguientes, esta tensión entre la lógica política-institucional y la lógica revolucionaria-armada produciría ciertas particularidades y dificultades en su forma de hacer política en la universidad.

El segundo proceso que indagamos para entender las experiencias de peronización a inicios de los setenta, fue el surgimiento de cuatro agrupamientos que encauzaron la actividad política y/o profesional de universitarios porteños: la ADUP, los EPT, el CT y la AAP. La primera era la equivalente de la JUP en el ámbito docente. Los dos siguientes se generaron específicamente para formar cuadros y políticas de gobierno y la última era un espacio de abogados peronistas enfocado a la defensa de presos políticos. De todos ellos, sólo ADUP y los EPT estaban referenciados a la JP Regionales-Montoneros, el resto se enmarcaba en el campo más amplio de la Tendencia Revolucionaria. Desde estas experiencias, la designación de Puiggrós en el cargo de interventor puede entenderse como una medida acorde al tono político que había dado a la UBA la movilización estudiantil en años anteriores; pero también como un reconocimiento a toda una franja del peronismo que había construido una fuerte base de apoyo en el mundo universitario.

La pregunta que queda abierta para el próximo capítulo es si estos grupos cuando se encontraron con la posibilidad de ocupar cargos en la UBA e influir en la política a seguir, habían debatido con anterioridad un proyecto de universidad. Para intentar responder a este interrogante, nos vamos a retrotraer a la revista Envido, con la finalidad de analizar cómo encararon el debate sobre la cuestión universitaria los estudiantes, docentes e intelectuales que

\footnotetext{
377 "Durante los años de politización universitaria, desde mediados de los "60 hasta 1976, ni la institución ni la Reforma serán ya productoras de identidad, y los partidos se encargarán de canalizar los conflictos”. Sigal, S., Intelectuales y poder en la década del sesenta, Bs. As., Puntosur, 1991, p. 71.
} 
se orientaron hacia el peronismo de izquierda en el contexto del retorno de Perón en 1972 y la asunción de Cámpora en 1973. 


\section{UN PROYECTO PARA LA UNIVERSIDAD \\ DE LA REVISTA ENVIDO A LA JUP Y ADUP \\ 1972-1973}

En este cuarto capítulo abordamos cómo debatieron la cuestión universitaria los grupos porteños de estudiantes, docentes e intelectuales que se orientaron al peronismo de izquierda en el contexto del retorno de Juan Domingo Perón en 1972 y las elecciones presidenciales de 1973. Luego de una introducción referida al modo en que Rodolfo Puiggrós y José María Rosa interpretaron en aquel entonces la relación entre el peronismo y los universitarios, analizamos la trayectoria de los principales integrantes de la revista Envido. Después tomamos como referencia a esta publicación para indagar si la creación de la Juventud Universitaria Peronista y la Agrupación Docente Universitaria Peronista trajo consigo la elaboración de una propuesta concreta para definir los fines, la estructura y la organización de las casas de estudio. Por último, analizamos cómo en 1972-73 el peronismo de izquierda formó parte de una red más amplia de revistas, diarios, libros y editoriales en la cual un conjunto de actores de diverso signo político diagnosticaba la crisis de la universidad argentina y sugería distintas recetas para solucionarla.

\section{I - DOS ENTREVISTAS COMO PUNTO DE PARTIDA}

Rodolfo Puiggrós visitó a Juan Domingo Perón en más de una oportunidad entre 1960 y 1970. Más allá del incomprobable hecho de que en uno de esos encuentros el general prometió nombrarlo rector de la Universidad de Buenos Aires (UBA) si retornaba a la Argentina, lo cierto era que esos contactos estuvieron acompañados de una articulación política entre ambos ${ }^{378}$. Al pasar puede nombrarse que Puiggrós acudió en 1970 a la asunción presidencial de Salvador Allende en representación de Perón y que un año después éste

\footnotetext{
${ }^{378}$ En 1977, ya exiliado en México, Puiggrós reveló en una entrevista que Perón le habría prometido el rectorado de la UBA en 1964. "El espíritu de Perón en las universidades argentinas", en Excelsior, México, 13 de febrero 1977. Adriana Puiggrós sostiene que esta promesa recién se la hizo Perón en una visita a Puerta de Hierro en 1967. Puiggrós, A., Rodolfo Puiggrós. Retrato familiar de un intelectual militante, Bs. As., Taurus, 2010, pp. 210-211.
} 
escribió el prólogo a la segunda edición del quinto tomo de la Historia Crítica de los Partidos Políticos Argentinos que el viejo militante comunista ya había titulado El Peronismo: sus causas $^{379}$. Pero lo más fructífero para Puiggrós era que en una de esas visitas a Puerta de Hierro, Perón había aceptado presidir un organismo del cual él fue secretario general. Esta agrupación constituida en 1971 se llamó Movimiento Argentino de Solidaridad Latinoamericana (MASLA) y, como su nombre sugería, estaba destinada a generar contactos políticos con mandatarios y organizaciones de otros países de la región. La creación del MASLA implicaba un nueva etapa en la relación de Puiggrós con el peronismo debido a que terminó afiliándose al Partido Justicialista (PJ) el 5 de enero de 1972 y formando parte de las arduas negociaciones que implicarían el retorno del peronismo al poder, como lo demostraría su presencia el 6 de julio de ese mismo año en el encuentro que encabezó Héctor Cámpora en el restaurante de la calle Cangallo al 900, el cual permitiría la constitución del Frente Cívico de Liberación Nacional (FRECILINA), la primera coalición encarada por el peronismo con miras a las elecciones de 1973, antes de formar el Frente Justicialista de Liberación Nacional (FREJULI) ${ }^{380}$.

Al poco tiempo de la fundación del MASLA, Puiggrós brindó una entrevista al periodista Tomás Saravi donde sintetizaba los lineamientos políticos de la agrupación ${ }^{381}$. En ella señalaba que a pesar de haberse creado desde el peronismo, pretendía incorporar a militantes de distintas extracciones que compartían un horizonte antiimperialista y revolucionario. A su entender, esta apertura era necesaria porque en ese entonces existían en la región múltiples estrategias políticas en los movimientos de masas e incluso en las luchas guerrilleras. Aunque lo que más resaltaba a la hora de valorar esa política de "puertas abiertas" era un fenómeno "impresionante" que comprobaba cuando visitaba universidades, centros culturales y políticos del país. Esta experiencia era lo que ya en esos años se nombraba como la "peronización" o "incorporación masiva" de jóvenes al peronismo. De todas maneras, Puiggrós advertía que no era una novedad absoluta si se tenía en cuenta que el primer peronismo también había surgido de la confluencia de personas y sectores con distintas militancias políticas. En este punto, parecía que estaba haciendo implícitamente alusión a su propia historia, porque a pesar de que se integró formalmente al peronismo con la fundación del MASLA en 1971 y su afiliación al PJ del año siguiente, él ya había brindado su

\footnotetext{
${ }^{379}$ La primera edición fue publicada en 1969 por Jorge Álvarez, mientras la segunda estuvo a cargo de Carlos Pérez Editor.

${ }^{380}$ Acha, O., La Nación Futura. Rodolfo Puiggrós en las encrucijadas argentina del siglo XX, Bs. As., Eudeba, 2006, pp. 224-225.

${ }^{381}$ Saravi, T., "Reportaje a Rodolfo Puggrós", en Envido, No 4, septiembre 1971, pp. 39-46.
} 
respaldo a los primeros gobiernos de Perón; adhesión que le costó la expulsión del Partido Comunista (PC) en 1947 y lo llevó a la creación del Movimiento Obrero Comunista $(\mathrm{MOC})^{382}$. Pero más allá de esta advertencia y de su trayectoria personal, Puiggrós continuaba resaltando la afluencia de jóvenes que no habían tenido ninguna militancia o provenían "desengañados" del radicalismo, el socialismo, la democracia cristiana, el comunismo y el trotskismo porque buscaban un "peronismo crítico" que se superaría así mismo con el paso al socialismo.

Como vimos en capítulos anteriores, estas declaraciones de Puiggrós de 1971 se sumaban a las voces de otros intelectuales y políticos de aquellos años que insistían una y otra vez en la necesidad de resaltar el acercamiento de los sectores medios al peronismo, sobre todo cuando hacían alusión a los jóvenes universitarios. No era extraño que llamara la atención este tipo de cuestiones. Uno de los grandes problemas que no había podido solucionar los primeros gobiernos de Perón había sido la militancia opositora de buena parte de la clase media y los universitarios. Esto incluso era reconocido por intelectuales que habían respaldado al peronismo desde sus inicios. Un año antes de las declaraciones de Puiggrós que comentamos en el párrafo anterior, el abogado e historiador José María Rosa había sido entrevistado por el mismo periodista Tomás Saravi ${ }^{383}$. En ese reportaje, donde hablaba de su antigua militancia liberal en el Partido Demócrata Progresista y de su acercamiento al revisionismo rosista, sostenía que el peronismo y la universidad no se habían entendido entre sí $^{384}$. A su parecer, uno de los grandes errores de Perón había sido el de designar rectores y decanos que eran ajenos a la universidad y sólo buscaban méritos partidarios. Esto no había hecho más que generar conflictos y malestares al interior de las casas de estudio, dónde incluso él mismo se había visto involucrado, cuando lo sumariaron por negarse a aprobar a un alumno por exigencia del decano de turno.

\footnotetext{
${ }^{382}$ El MOC primero se llamó Movimiento Pro Congreso Extraordinario. Existió entre 1947 y 1956. Puiggrós fue su secretario general, Pedro Valla su secretario de organización y el trabajador textil Próspero Malvestitti su secretario del rubro sindical. Tarcus, H. (dir.), Diccionario biográfico de la izquierda argentina, Bs. As., Emecé, 2007, pp.532-533.

${ }^{383}$ Saravi, T., "Reportajes Biográficos: José María Rosa”, en Envido, № 2, noviembre 1970, pp. 40-51.

${ }^{384}$ Como sostienen Devoto y Pagano, la categoría "revisionismo" es extremadamente ambigua y puede hacer referencia a un conjunto de historiadores con trayectorias políticas e intelectuales disímiles. En el caso de Rosa, tuvo una carrera política que lo llevó del Partido Demócrata Progresista al conservadurismo y luego al nacionalismo. Si bien tuvo varios cargos políticos anteriores, en 1943 ocupó por un breve tiempo la presidencia del Consejo de Educación en la provincia de Santa Fe. Además, a diferencia de otros revisionistas, desarrolló una extensa carrera como docente en la Universidad del Litoral, la UNLP y la UBA. En el ' 55 fue separado de todos sus cargos con el derrocamiento del peronismo. Según Acha, luego de esa fecha se acercó a algunos "ideologemas del marxismo de la época" en libros como La Guerra del Paraguay y las montoneras argentinas (1965) e Historia del revisionismo y otros ensayos (1968), aunque a su entender siempre siguió fiel a su nacionalismo. Devoto, F., y Pagano, N., Historia de la historiografia argentina, Bs. As., Sudamericana, 2010, pp. 254-256; Acha, O., Historia Crítica de la historiografía argentina. Vol. 1: las izquierdas en el siglo XX, Bs. As., Prometeo, 2009, pp. 308-309.
} 
Pero más allá de las opiniones particulares de Rosa y Puiggrós en relación a la universidad del primer peronismo y la peronización de los sectores medios, conviene preguntarse qué pensaba sobre estos temas la joven generación de estudiantes, docentes e intelectuales que había iniciado su carrera universitaria con posterioridad al golpe de Estado de 1955 y consideraba a la bibliografía del ex comunista y del historiador nacionalista como referencias importantes en su acercamiento al peronismo ¿Cómo explicaban el conflicto entre Perón y los universitarios? ¿Tenían un diagnóstico sobre el modelo de universidad de sus primeros gobiernos? ¿Creían necesario volver a ese a proyecto universitario o proponían otro en consonancia con las transformaciones vividas en los años sesenta y setenta? ¿Decían algo sobre la Reforma de 1918 cuando rememoraban al primer peronismo y reflexionaban sobre su nueva adscripción a dicho movimiento? ¿O dado que ponían el acento en la idea de revolución y socialismo nacional no tenían nada que decir sobre la Reforma ni sobre la universidad justicialista de la década del cuarenta y cincuenta?

En el segundo capítulo abordamos estos interrogantes a través del análisis de la revista Antropología 3er. Mundo. Si queremos profundizar la discusión sobre la cuestión universitaria que realizaron los grupos porteños de estudiantes, docentes e intelectuales que se orientaron al peronismo de izquierda en el contexto del retorno de Perón de 1972 y las elecciones presidenciales de 1973, no puede pasarse por alto la revista donde fueron publicados los reportajes que Saravi realizó a Rosa y Puiggrós. La misma fue titulada Envido en alusión al popular juego de cartas españolas y la mayoría de su staff estuvo integrado por universitarios peronizados que habían hecho sus primeros pasos militantes e intelectuales en el Movimiento Humanista Renovador (MHR) y en el Centro Argentino de Economía Humana (CAEH). Lo interesante de esta publicación fue que sus notas siguieron de cerca la constitución de la Juventud Peronista Regionales (JP Regionales), la campaña Luche y vuelve y el triunfo electoral del peronismo. Ya en los albores de la asunción presidencial de Héctor Cámpora, en sus páginas aparecieron un conjunto de documentos de los frentes de masas de la JP Regionales donde se analizaba la nueva situación política y se proponían un conjunto de medidas específicas para implementar en distintas áreas de gobierno. Entre ellos, tuvieron un lugar destacado los proyectos de universidad propuestos por la Agrupación Docente Universitaria Peronista (ADUP) y la Juventud Universitaria Peronista (JUP). Por esta razón, un repaso crítico por las notas y los debates de Envido permite revisar cómo fue discutido el perfil de la universidad por parte de las agrupaciones que canalizaron la afluencia de sectores medios al peronismo, sin desconocer que sus discursos estaban atravesados por varias redes de sentidos surgidos en los múltiples cruces entre el campo político, cultural y académico de 
esos años convulsionados por las constantes mutaciones de la dinámica política.

\section{II - UNA REVISTA PERONISTA DE POLÍTICA Y CIENCIAS SOCIALES}

Miguel Hurst ingresó a la carrera de Sociología en los años sesenta. Su actividad como estudiante era acompañada de un oficio que también le permitía un intercambio constante con alumnos, docentes e intelectuales que frecuentaban las aulas de Filosofía y Letras de la UBA en aquel entonces. Tenía una librearía llamada Cimarrón, donde podían conseguirse "apuntes" de varias materias y estaba ubicada en la calle Independencia al 3113, a tan sólo una cuadra de la facultad ${ }^{385}$. A principios de los setenta, Hurst ideó una revista políticocultural y se la propuso dirigir a Arturo Armada, quien a inicios de la década anterior había ingresado a la carrera de Letras pero luego del golpe de Juan Carlos Onganía siguió su formación universitaria en Filosofía. En esos primeros años, ambos habían comenzado su militancia estudiantil en el MHR y formado parte de un instituto denominado $\mathrm{CAEH}^{386}$.

¿Cómo era la publicación que Hurst le propuso conducir a Armada e incluso hasta aportó los fondos necesarios para la impresión de la primera edición? La misma se llamó Envido y bajo el subtítulo de Revista de política y ciencias sociales publicó diez números entre 1970 y 1973 . Formalmente se presentaba como una publicación trimestral, aunque como todo trabajo autogestionado no pudo mantener la regularidad anhelada: en 1970 apareció el primer número en julio y el segundo en noviembre. Al año siguiente, el tercero en abril y el cuarto en septiembre; mientras el quinto, sexto y séptimo datan en marzo, julio y octubre de 1972. Ya en 1973, se editaron el octavo en marzo, el noveno en mayo y el décimo, si bien registra impreso el mes de noviembre, recién pudo distribuirse en diciembre de ese mismo año ${ }^{387}$. Las fechas de sus respectivos ejemplares dejan ver que la revista atravesó el ocaso de la Revolución Argentina, el Gran Acuerdo Nacional (GAN) convocado por Alejandro Lanusse, el retorno de Perón a la Argentina, la elección de Cámpora como presidente, su misma destitución y hasta los primeros pasos del tercer mandato del repatriado líder del peronismo.

La autotitulación de Envido como Revista de política y ciencias sociales en cierta medida sintetizaba el objetivo editorial de crear un ámbito de debate sobre la coyuntura del

\footnotetext{
${ }^{385}$ González, H., "Envido, un frente intelectual en el lodo del lenguaje político", en Envido. Revista de política y ciencias sociales, Bs. As., edición facsimilar de la Biblioteca Nacional, 2011, Tomo I, p. 11; Gianella, C. (comp.), La vida es Perón. Historia del Encuadramiento de la Juventud Peronista, Bs. As., Biblos, 2012, p. 97. ${ }^{386}$ Entrevistas a Arturo Armada, C.A.B.A., 15/12/2015 y 29/12/2015.

${ }^{387}$ Entrevista a Arturo Armada por Norberto Raffoul y Rodolfo Beltramini, 19/04/2008. En Envido. Revista de política y ciencias sociales, edición facsimilar de la Editorial de la Facultad de Filosofía y Letras, UBA, 2010, pp. X-XI.
} 
país sin dejar de situar su labor desde la producción y el trabajo intelectual. En términos generales esta propuesta no era novedosa, tenía como antecedentes inmediatos a otras publicaciones político intelectuales como Contorno, Pasado y Presente e incluso a la misma Antropología 3er. Mundo. Muchas de estas experiencias, hoy en día catalogadas como revistas de la nueva izquierda argentina, compartían la actitud de enmarcar su tarea intelectual en proyectos políticos más amplios que hablaban de peronismo, socialismo y revolución ${ }^{388}$. Aunque lo hicieron desde diversas trayectorias y opciones políticas. En el caso de Envido, su énfasis discursivo estuvo en articular todas esas ideas a través del concepto de dependencia estructural. La contratapa de su segunda número fechado en noviembre de 1970 era sugestiva al respecto, ya que presentaba a la publicación como una "revista trimestral de información, crítica y documentación" sobre los problemas políticos y culturales del tercer mundo. A lo que sumaba una caracterización de sus integrantes como profesionales que "tomaban conciencia" de que su actividad, la vida cotidiana y toda la historia del país estaban condicionadas por la dependencia nacional ${ }^{389}$.

Donde mejor se explicitó este enfoque general que mantuvo Envido en todo su recorrido fue en la nota "La contradicción principal en la estructuración dependiente", la cual inauguró el primer ejemplar de la revista en julio de 1970. La misma estaba firmada por su consejo de redacción, con la intención de dar a entender que era la línea editorial de todo el colectivo, pero fue escrita por su director y por José Pablo Feinmann ${ }^{390}$, uno de los primeros integrantes del staff que en ese momento era docente de Historia de la Filosofía Contemporánea en la Facultad de Filosofía y Letras ${ }^{391}$. El mismo Armada lo había convocado a formar parte de Envido luego de haber cursado juntos el seminario sobre pensamiento argentino que dictaba Guillermina Garmendia de Camusso junto a Nélida Schnait y Amelia Podetti, docente de las Cátedras Nacionales $(\mathrm{CN})$ que posteriormente se convertiría en un cuadro político de Guardia de Hierro ${ }^{392}$. Tal como lo evidenciaba su título, la nota escrita por ambos para enmarcar la tarea intelectual y política de Envido tenía básicamente dos ideas

\footnotetext{
${ }^{388}$ Tortti, M. C., Che. Una revista de la nueva izquierda (1960-1961), Bs. As., CEDINCI, 2013; Celentano, A., Revistas y libros de la nueva izquierda intelectual, Dossier $\mathrm{N}^{\circ} 84$, Programa Interuniversitario de Historia Política, julio 2016.

${ }^{389}$ Envido, No 2 , noviembre 1970.

${ }^{390}$ En una nota en Página 12 y en su libro La Sangre Derramada, Feinmann da a entender que escribió él solo la editorial. Esto lo desmiente el propio Armada en la polémica que sostiene con Feinmann y Horacio González a propósito de la historia de Envido. Véase: Feinmann, J. P., "La historia con pasión”, en Página 12, 11 de marzo 2000; Feinmann, J. P., La Sangre Derramada, Bs. As., Booket, 2007, p. 71.; Armada, A., “Envido: por sus frutos los conoceréis", en El ojo mocho, № 16, verano 2001-2002, p. 158.

${ }^{391}$ En 1970, Feinmann era Jefe de Trabajos Prácticos de esta materia de la Facultad de Filosofía y Letras de la UBA. Véase: Feinmann, J. P., El peronismo y la primacía de la política, Bs. As., Planeta, 2015, p. 7.

${ }^{392}$ Denaday, J. P., "Amelia Podetti: una trayectoria olvidada de las Cátedras Nacionales", en Nuevo Mundo Mundos Nuevos, 29 de agosto 2003, párrafo 5.
} 
centrales que justificaban con citas explícitas y alusiones a Carlos Marx, Günder Frank, Herbert Marcuse y Mao Tse-Tung. La dependencia estructural o estructuración dependiente hacía referencia a que sin la explotación del resto del mundo el capitalismo no habría podido existir ni desarrollarse. Como "nació imperialista", siempre necesitó el dominio económico, político y cultural de los países centrales sobre los periféricos. La contradicción principal, por su parte, daba a entender que el conflicto más importante a resolver para erradicar al sistema capitalista ya no era el de burguesía-proletariado, sino la antinomia imperialismo-nación porque sólo la independencia de los enclaves coloniales o neocoloniales podría desarticular su verdadera fuente de sustentabilidad. Estas dos ideas eran la base de la principal toma de posición política de Envido: el peronismo era el movimiento de liberación propio de la Argentina y el único capaz de hacer realidad una etapa superior al capitalismo a la que denominaban, no sin cierta ambigüedad, como socialismo nacional ${ }^{393}$.

Desde esta tónica general, la revista abordaba discusiones políticas, culturales, científicas y profesionales. Las tres últimas eran trabajadas a partir de una gran diversidad de temáticas y experiencias que iban desde la sociología, la ingeniería, la arquitectura, los nuevos estudios sobre salud mental hasta el cine, el tango y la literatura. Al respecto, resultan ilustrativos artículos como "Leopoldo Torre Nilson o la venganza de las vacas" de Abel Posadas ( $\mathrm{N}^{\mathrm{o}} 1$ y 2); "La explotación de la sociología” de Ernesto Villanueva (No 2); "Manzi y Discepolín: el tango en la década infame" de Santiago González ( $\left.\mathrm{N}^{\mathrm{o}} 4\right)$; "El ingeniero en la transición hacia el socialismo nacional" de Oscar Varsavsky ( $\mathrm{N}^{\mathrm{o}}$ 5); "La transferencia de tecnología, arma del imperialismo" de Héctor Abrales ( $\mathrm{N}^{\mathrm{o}}$ 6) y "La penetración imperialista en el campo de la salud mental" de Hernán Kesselman $\left(\mathrm{N}^{\mathrm{o}} 7\right)$. Como muestran los títulos de las notas descriptas, Envido ponía en primer plano la dependencia y trataba múltiples cuestiones culturales, científicas y profesionales, pero sin ignorar la especificidad propia de cada área. Sus autores tomaban la palabra por estar avezados en un campo particular, lo cual

\footnotetext{
${ }^{393}$ Consejo de Redacción, "La contradicción principal en la estructuración dependiente", en Envido, № 1, julio 1970. Como señalamos en capítulos anteriores, estas lecturas de los jóvenes intelectuales peronistas que concebían al movimiento como una vía para encarar la liberación nacional y la revolución social también eran deudoras de la producción intelectual de Juan José Hernández Arregui, John William Cooke y el propio Puiggrós. Este último caracterizaba a este tipo de enfoques como "nacionalismos populares revolucionarios". Los trabajos actuales difieren en la manera de catalogar a estos referentes político-intelectuales. Mientras Georgieff sitúa a Puiggrós y Hernández Arregui dentro de la tradición de la izquierda nacional, Acha sostiene que Cooke y Hernández Arregui junto a Rodolfo Ortega Peña y Eduardo Duhalde fundaron una visión y una historiografía propia de la izquierda peronista, la cual se distingue tajantemente de la izquierda nacional. Más allá de las clasificaciones, en sus análisis todos mixturaban el marxismo, el nacionalismo y el peronismo. Para profundizar estos debates, véase: Georgieff, G., Nación y revolución. Itinerarios de una controversia en Argentina (1960-1970), Bs. As., Prometeo, 2008, p. 80 y 89; Acha, O., Ob. cit., 2009, p. 307. En relación a la caracterización de "nacionalismo popular revolucionario", puede consultarse: Puiggrós, R., "Tesis sobre el Nacionalismo Popular Revolucionario", en Las Izquierdas y el Problema Nacional, Bs. As., Ediciones Cepe, 1973, pp. 187-194.
} 
constituía una forma especial de intervención que no se reducía al hecho de compartir una perspectiva política de carácter general.

Por otra parte, la revista de Armada abordaba el debate político desde distintos ángulos. Sus estudios, ensayos, notas de opinión y entrevistas intercalaban el análisis de coyuntura, la discusión teórica y la revisión de la historia político-intelectual de nuestro país. En este punto, no pueden obviarse los editoriales de su director o la sección Crónica Política que realizaba Jorge Luis Bernetti bajo el seudónimo de Claudio Ramírez en casi todos los números, excepto en el octavo y noveno que estuvo a cargo de Santiago González ${ }^{394}$. Tampoco las entrevistas de Saravi a Puiggrós y a Rosa que nombramos al inicio del capítulo, como los trabajos de Feinmman. Este último dedicó la mayoría de sus escritos a la crítica del pensamiento político argentino del siglo XIX y al debate sobre la interpretación del peronismo, en los cuales no estuvieron ausentes José Hernández, Felipe Varela, Sarmiento, ni autores marxistas contemporáneos como Milcíades Peña, Miguel Murmis y el ya nombrado Juan Carlos Portantiero ${ }^{395}$. Estos trabajos fueron la base de su primer libro El peronismo y la primacía de la política que editaría tiempo después el propio Hurst bajo el sello Cimarrón ${ }^{396}$. Entre las indagaciones políticas de Envido que pivoteaban entre la pesquisa de sucesos coyunturales de ese momento y las reflexiones teóricas más amplias sobre el peronismo, el marxismo y la dependencia, también pueden destacarse "Imperialismo y coloniaje" de Roberto Carri ( $\mathrm{N}^{\mathrm{o}}$ 3); “Tercera Posición, marxismo y tercer mundo” de Rubén Dri (No 4); "Humanismo

\footnotetext{
${ }^{394}$ Bernetti tuvo un papel activo en Envido. Sus crónicas estaban centradas en el análisis de la coyuntura argentina de principios de los setenta. Sus títulos eran representativos al respecto: "Crónica política de enero a abril" ( $\left.\mathrm{N}^{\circ} 1\right)$; "Salida política y conciliación nacional" $\left(\mathrm{N}^{\circ} 2\right)$; "Cambio de fusibles en el gobierno" $\left(\mathrm{N}^{\circ} 3\right)$, "Gobierno: el callejón del Gran Acuerdo" ( $\left.\mathrm{N}^{\circ} 4\right)$; "El retroceso del régimen y el avance de Perón" ( ${ }^{\circ}$ 5); "El Frente contra el GAN." ( $\mathrm{N}^{\circ}$ 6); "Luche y vuelve" ( $\left.\mathrm{N}^{\circ} 7\right)$. Santiago González continuó esta línea y escribió "Crónica del fracaso lanussista" ( $\left.\mathrm{N}^{\circ} 8\right)$ y "Crónica del triunfo popular" $\left(\mathrm{N}^{\circ} 9\right)$. El décimo ejemplar de Envido no tiene la sección Crónica Política. En este número se produjo un cambio hacia una forma de dirección colectiva donde las notas no fueron firmadas.

${ }^{395}$ Entre los artículos de Feinmann, pueden nombrarse: "Felipe Varela y la lógica de los hechos" $\left(\mathrm{N}^{\circ} 2\right)$; "Racionalidad e irracionalidad en Facundo" ( $\left.\mathrm{N}^{\circ} 3\right)$; "Sobre el peronismo y sus interpretes" ( $\mathrm{N}^{\circ} 6$ y 7); "Cooke: peronismo e historia" ( $\left.\mathrm{N}^{\circ} 8\right)$; entro otros. Las notas del sexto y séptimo número son las más relevantes. En ellas, Feinmann retomaba el debate sobre los orígenes del peronismo que Murmis y Portantiero habían entablado con Gino Germani. Frente a la idea de que su aparición se debía a una clase obrera sin experiencia originada en las migraciones internas por la industrialización, Murmis y Portantiero sostenían que en verdad habían jugado un rol clave sindicatos que tenían un recorrido importante tras de sí, los cuales entablaron autónomamente una alianza con Perón para hacer efectivas sus demandas. Lo que les cuestionaba Feinmann es que luego de reconocer este hecho importante, ambos afirmasen que durante el gobierno peronista la clase obrera había terminado subordinada a la élite política, porque ésta había erradicado al Partido Laborista y a la autonomía de los sindicatos mediante su control estatal. Para Feinmann, no existían razones para sostener tajantemente que cuando los sindicatos se incorporan al Estado pierden su autonomía. Además, les inquiría una explicación de por qué si el peronismo fue sólo una manipulación de la clase obrera desde el Estado, los trabajadores lo seguían reivindicando como su identidad política luego de su derrocamiento en 1955. Véase: Murmis, M., y Portantiero, J. C., Estudios sobre los orígenes del peronismo, Bs. As., Siglo XXI, 1972; Feinmann, J. P., "El peronismo y sus intérpretes", en Envido, Nㅜ 6, julio 1972, pp. 20-21.

${ }^{396}$ A fines de 1973, Hurst le propuso publicar el libro a Feinmann. Terminó siendo editado en junio de 1974. Feinmann, J. P., Ob. cit., 2015, p. 15.
} 
y Estrategia en Juan Perón" de Horacio González ( ${ }^{o}$ 4); "Peronismo o desarrollismo" de Juan Pablo Franco y Fernando Álvarez ( $\mathrm{N}^{\mathrm{o}}$ 6); y "El gobierno popular y la construcción del socialismo nacional" de Horacio Fazio ( $\mathrm{N}^{\circ}$ 9).

El tratamiento de temas políticos siempre fue una marca característica de la revista, pero a partir del quinto número de 1972 adquirió un matiz especial ya que una serie de consignas empezaron a encabezar las portadas de la publicación. Las más importantes y llamativas fueron "El Socialismo Nacional como Objetivo" ( $\left.\mathrm{N}^{\circ} 5\right)$, "Perón Vuelve" $\left(\mathrm{N}^{\circ} 7\right)$, “Gobernar es Movilizar" ( $\mathrm{N}^{\circ}$ 9) y "Perón al Poder" $\left(\mathrm{N}^{\circ} 10\right)$. Estos lemas sintetizaban su posicionamiento ante el escenario político de principios de los setenta y su identificación con el sector del peronismo que terminaría encabezando el tándem JP Regionales-Montoneros, cuando este apostó de lleno al incierto retorno de Perón a la Argentina y luego tuvo un protagonismo importante en el posterior triunfo electoral del FREJULI, como en la misma asunción presidencial de Cámpora. La ubicación política de Envido también se reflejó en la publicación de una gran cantidad de notas firmadas por los frentes de masas de la JP Regionales o por agrupamientos de la Tendencia Revolucionaria con fuertes afinidades políticas con dicha organización juvenil. Entre los primeros, podemos nombrar a la Juventud Trabajadora Peronista (JTP), los Equipos Político-Técnicos (EPT), ADUP y la JUP ${ }^{397}$. Entre los segundos, al Movimiento de Sacerdotes para el Tercer Mundo, el Consejo Tecnológico (CT) del Movimiento Nacional Justicialista (MNJ) y las 62 Organizaciones de Córdoba ${ }^{398}$. No obstante, Envido nunca se presentó como una revista orgánica de una agrupación política particular y cuando aceptó una propuesta para vincularse a Montoneros luego de su noveno número, esta no fructífero debido a la indiferencia de la organización armada hacia la producción de la revista y por las repercusiones del asesinato de José Ignacio Rucci a sólo dos días de la tercera elección presidencial de Perón.

Pero más allá de esta última cuestión que será retomada en el capítulo siguiente, corresponde señalar que la experiencia de Envido fue una clara expresión de la opción por el peronismo de izquierda de diversos grupos universitarios porteños. Así lo evidencia la trayectoria de la mayor parte de los miembros del consejo de redacción que conformó Armada y del "grupo promotor" que encabezó Hurst para administrar económicamente la revista y garantizar su distribución. Este último estaba compuesto por el sacerdote Domingo Bresci, la filósofa Susana Sciannameo y Eduardo Clausen, quien al igual que Hurst estudiaba en la carrera de Sociología y era su socio en la librería Cimarrón. En cambio, el consejo de redacción de los

\footnotetext{
${ }^{397}$ Envido, $\mathrm{N}^{\circ} 7,8,9$ y 10.

${ }^{398}$ Envido, № 1, 2, 4, 7 y 9.
} 
tres primeros números estuvo integrado por Feinmann, el economista Manuel Fernández López, el psicólogo Carlos Alberto Gil, el periodista Santiago González, el filósofo Bruno Roura y el propio Bresci. Luego fue sufriendo bajas y otras incorporaciones, como las del periodista Bernetti, el sociólogo Horacio González, el ingeniero químico Héctor Abrales y el economista Horacio Fazio. La articulación Hurst-Armada como dúo fundador de Envido y los nombres que eligieron para integrarla se explican en buena medida porque en la primera mitad de los sesenta la mayoría de ellos había participado en dos espacios ya mencionados que tenían conexiones entre sí: el MHR y el CAEH.

\section{DEL HUMANISMO AL PERONISMO}

El MHR fue una agrupación estudiantil de la Facultad de Filosofía y Letras marcada por los aires renovadores del Concilio Vaticano II. Su influencia más relevante en ese entonces era la del personalismo filosófico cristiano de Emmanuel Mounier. Él editaba en Francia la revistalibro Esprit, que al igual que Les Temps Modernes discutía desde filosofía hasta economía, pasando por la política y las artes, con números temáticos, secciones fijas y fuerte contenido teórico $^{399}$. A principios de los sesenta, Armada, Hurst, Gil, Santiago González, Roura, Sciannameo y Clausen engrosaron las filas del MHR, cuando la organización participaba en las elecciones del centro de estudiantes, del diálogo entre cristianos y marxistas, y canalizaba un incipiente acercamiento al peronismo. El 16 de septiembre de 1964 participó junto a otros grupos en la toma del rectorado de la UBA en repudio de un nuevo aniversario de la "Revolución Libertadora", en medio del Plan de Lucha de la CGT y a poco del retorno frustrado de Perón a la Argentina ${ }^{400}$.

El CAEH, por su parte, fue creado en 1963. Era una institución que realizaba conferencias, investigaciones y publicaciones sobre economía, sociedad y el rol de los católicos en los procesos de cambio. Contaba con conexiones en el medio universitario y

\footnotetext{
${ }^{399}$ Mounier (1905-1950) fue un filósofo socialcristiano francés que participó en la resistencia contra el nazismo y creó la noción de "socialismo personalista", en su intento de llevar a cabo una síntesis entre la perspectiva socialista y cristiana. Sus escritos tuvieron una profunda influencia en los grupos posconciliares de América Latina. En 1932 fundó la revista Esprit, la cual tras su muerte en 1950, fue dirigida por Albert Béguin y después por Jean-Marie Domenach. Desde 1988, encabeza la revista Olivier Mongin. En testimonios actuales, Armada resalta la admiración que tenían en ese momento por las revistas-libro francesas como Esprit y Les Temps Modernes. Entrevista a Arturo Armada por Norberto Raffoul y Rodolfo Beltramini, 19/04/2008. En Envido. Revista de política y ciencias sociales, edición facsimilar de la Editorial de la Facultad de Filosofía y Letras, UBA, 2010, p. XI.

${ }^{400}$ En el primer capítulo de esta investigación ya abordamos cómo se manifestó el diálogo entre católicos y marxistas en la propia Facultad de Filosofía y Letras. También la situación general del humanismo en la UBA, el cual llegó a contar con dos rectores propios en la primera mitad de los sesenta: Julio Olivera e Hilario Fernández Long.
} 
sindical por su cercanía al MHR y a la Asociación Sindical Argentina (ASA) ${ }^{401}$. Se formó bajo la influencia del sacerdote dominico Joseph Lebret, quien a fines de los cincuenta había participado en la fundación del Centro Latinoamericano de Economía Humana (CLAEH) en Montevideo y luego fue uno de los principales impulsores del Concilio Vaticano II, con una prédica que reclamaba la renovación del pensamiento cristiano y el compromiso católico ante la injusticia social ${ }^{402}$. En nuestro país, los universitarios que participaban en el CAEH editaban una revista llamada Cambio, en cuyas páginas no sólo había citas de Mounier y Pierre Teilhard de Chardin ${ }^{403}$, sino que además se hablaba de la necesidad de crear una "universidad nueva" en una "argentina liberada" ${ }^{404}$. En este centro signado por la politización y los cambios posconciliares del mundo católico, participaron Armada, Hurst y Clausen, pero también otros futuros "envidistas" que no integraron el MHR, como Abrales y Bernetti ${ }^{405}$. El primero había sido representante del humanismo en la comisión directiva del Centro de Estudiantes de Ingeniería "La Línea Recta"406, mientras el segundo había participado en el Movimiento Independiente y en la Juventud Estudiantil Católica en sus años de estudios secundarios en el Colegio Nacional Buenos Aires. A lo que se sumaba, al igual que en el caso de Armada, su paso por Democracia Cristiana (DC) antes de producirse el golpe de Estado de Onganía en $1966^{407}$.

En el trascurso de la segunda mitad de los sesenta, dos intelectuales que también habían tenido una temprana militancia en la DC fueron claves en el pasaje al peronismo de varios integrantes de Envido que habían hecho sus primeros pasos en el MHR y el CAEH. Uno de ellos fue Conrado Eggers Lan, el destacado profesor de Filosofía y Letras que nombramos en más de una oportunidad. Ya sea desde sus cátedras de Filosofía Antigua y

\footnotetext{
${ }^{401}$ La ASA fue fundada en octubre de 1955 por iniciativa de referentes de la Juventud Obrera Católica (JOC). Su objetivo fundacional era reemplazar a la dirigencia peronista de los sindicatos cuando fueron intervenidos por los militares. Sin embargo, progresivamente fue abandonando su antiperonismo y se incorporó finalmente a la CGT a principios de los sesenta. Esto permitió al CAEH realizar cursos de capitación en la central obrera. Donatello, L. M., Catolicismo y Montoneros, Bs. As., Manantial, 2010, pp. 52-53.

${ }^{402}$ Lebret (1897-1966) ya había fundado durante 1940 el centro de estudios "Economía y Humanismo" en Lyon. Uno de los objetivos de su obra era realizar una síntesis teórica entre el socialismo y el pensamiento cristiano.

${ }^{403}$ Teilhard de Chardin (1881-1955) fue un sacerdote jesuita francés. Como paleontólogo, teólogo y filósofo intentó adaptar la teoría de la evolución de Darwin al catolicismo. Sus investigaciones influyeron fuertemente en el pensamiento cristiano de la segunda mitad del siglo XX.

${ }^{404}$ La historia del CAEH se reconstruye contemporáneamente en el libro Los católicos posconciliares en la Argentina que editó en 1970 el propio Armada junto a Norberto Habegger y Alejandro Mayol. Lo interesante de este trabajo es que no sólo contiene un análisis de los autores, sino una serie de documentos sobre el proceso de renovación posconciliar del catolicismo. La publicación fue posible porque Armada trabajaba en la editorial Galerna, en el párrafo siguiente abordamos las conexiones que estableció a partir de esta labor con otros docentes e intelectuales de la época. Mayol, A., Habegger, N., y Armada, A., Los católicos posconciliares en la Argentina, Bs. As., Galerna, 1970, pp. 127-128.

${ }^{405}$ Entrevistas a Arturo Armada, C.A.B.A., 15/12/2015 y 29/12/2015.

${ }^{406}$ Baschetti, R., Militantes del peronismo revolucionario uno por uno, en www.robertobaschetti.com

${ }^{407}$ Entrevista a Jorge Luis Bernetti, C.A.B.A, 06/02/2016.
} 
Antropología Filosófica, en el sin fin de conferencias que brindaba o en los grupos de estudio y discusión política que integraba, su papel fue relevante para encauzar el diálogo de cristianos con marxistas y el posterior ingreso al peronismo ${ }^{408}$. Los títulos de buena parte de sus libros de aquellos años eran en sí mismos una expresión del cauce de politización y peronización de una parte del activismo cristiano. En 1964 publicó Cristianismo, Marxismo y Revolución Social y en 1968 Cristianismo y Nueva Ideología, ambos editados por Jorge Álvarez. Ya a fines de los sesenta y principios de los setenta, escribió Violencia y estructuras (1971), Izquierda, peronismo y socialismo nacional (1972) y Peronismo y liberación nacional (1973). Estos últimos trabajos fueron publicados por Ediciones Búsqueda, un emprendimiento que encabezó el psicólogo y ex militante del MHR Jorge Rodríguez.

El otro intelectual relevante en la peronización de varios "envidistas" de origen cristiano fue Gonzalo Cárdenas por haber sido uno de los referentes del CAEH y una de las principales figuras de las CN. Un año antes de convertirse en director de Envido, Armada trabajaba en la editorial Galerna y publicó Las Luchas Nacionales Contra la Dependencia (1969) en la colección Problemas latinoamericanos, un trabajo de Cárdenas muy leído en el ambiente universitario porteño cercano o identificado con el peronismo ${ }^{409}$. Ese mismo año, también editó en la colección el libro Ser Social y Tercer Mundo que involucraba a otros tres integrantes de las CN: al autor Norberto Wilner, su director de tesis, Justino O’ Farrell, y a la prologuista, Amelia Podetti ${ }^{410}$. Si bien cuando comenzó a salir Envido a mediados de 1970, Cárdenas empezó a sufrir problemas psíquicos y una frustrada militancia en Encuadramiento, estas redes de contactos previos explican la participación de muchos $\mathrm{CN}$ en la revista, como Ernesto Villanueva, Roberto Carri, Alcira Argumedo, O’ Farrell, Juan Pablo Franco y Fernando Álvarez ${ }^{411}$. Aunque el único que integró su consejo de redacción fue Horacio

\footnotetext{
${ }^{408}$ Como vimos en el primer capítulo, Eggers Lan había entablado una polémica sobre marxismo y cristianismo con León Rozitchner entre 1962 y 1964. La misma tuvo lugar en las páginas de Pasado y Presente, luego de las repercusiones que trajo una entrevista a Eggers Lan en el Correo de C.E.F.Y.L, la publicación del centro de estudiantes de la Facultad de Filosofía y Letras de la UBA.

${ }^{409}$ Cárdenas, G., Las luchas nacionales contra la dependencia, Bs.As., Galerna, 1969. En el primer capítulo, vimos que Cárdenas escribió especialmente este libro con el fin de utilizarlo como material para su cátedra de Historia Social Argentina, una de las asignaturas que integraba el conjunto de materias que los alumnos de la Facultad de Filosofía y Letras nombraban como "Cátedras Nacionales".

${ }^{410}$ Wilner, N., Ser Social y Tercer Mundo (Elementos para una lógica de lo nacional), Bs. As., Galerna, 1969. Este libro era la tesis de licenciatura en filosofía de Wilner que dirigió O'Farrell. La prologuista, Podetti, aclaraba esto en las primeras páginas y en la portada se presentaba a Wilner como docente de Sociología Sistemática, otra de las materias de las $\mathrm{CN}$.

${ }^{411}$ La organización Encuadramiento de la Juventud Peronista tuvo una trayectoria que no está disociada de actores provenientes de la izquierda. Sus orígenes se remontan a escisiones de grupos trotskistas argentinos, si es considerado el caso de su fundador y líder Juan Carlos Bardoneschi. A principios de los setenta, entabló vinculaciones con Jorge Daniel Paladino, el delegado personal de Perón. Desde 1973, el Encuadramiento (o "los Demetrios", en alusión al nombre de uno de los principales integrantes de la agrupación, Demetrio Tarazzi) conformó los espacios de la "ortodoxia peronista" opuestos a la izquierda y a Montoneros. Por un tiempo,
} 
González, quien como vimos no provenía de una militancia cristiana, pero conocía al MHR por haber frecuentado el ambiente estudiantil de Filosofía y Letras en la primera mitad de los sesenta cuando participaba en la Tendencia Antiimperialista Universitaria (TAU), agrupación de izquierda dirigida en ese entonces por Wilner.

Hacia 1972-73 los miembros más importantes de Envido terminaron de integrarse al sector de la Tendencia Revolucionaria que hegemonizó Montoneros. El propio Armada y Horacio González realizaron militancia territorial en la JP Regionales, el primero en la zona de Florencia de Varela y el segundo en Floresta. Este último también había tenido un paso previo por el Movimiento Revolucionario Peronista (MRP) ${ }^{412}$. Hurst y Clausen, los socios de Cimarrón, ingresaron a las filas de la Agrupación de Estudiantes Peronistas (AEP), la cual era parte del MRP. Como vimos, AEP fue una de las agrupaciones que conformó la JUP en el ' $73^{413}$. A lo que se sumaba que en marzo de ese mismo año el propio Hurst resultó electo concejal en San Isidro en representación de la JP Regionales. Abrales, por su parte, ya en aquel momento era uno de los principales profesionales e investigadores del CT que presidía Rolando García desde $1972^{414}$. También integraba el colectivo de asesores de la revista Ciencia Nueva que dirigió Ricardo Ferraro entre 1970 y 1974. En esta publicación, donde se discutía el papel político de la producción científica y tecnológica, escribieron importantes figuras de los "tiempos dorados" de la UBA que se terminaron acercando al peronismo, como el propio García, Varsavsky y Manuel Sadosky ${ }^{415}$. No por nada, Ciencia Nueva fue uno de los medios que difundió el primer documento del CT donde se recalcaba la importancia de la "doctrina justicialista" y la necesidad de establecer el socialismo nacional ${ }^{416}$.

Cárdenas entabló relaciones con este sector hasta que problemas psíquicos progresivamente lo alejaron de la política y de su actividad universitaria a principios de los setenta. Sobre Encuadramiento puede consultarse: Gianella, C., Ob. cit., 2012; Ortiz, N., ¿Peronistas de Perón? Historia testimonial del encuadramiento de la Juventud Peronista, C.A.B.A., Biblioteca Nacional, 2015. Para una caracterización de la época: Bonasso, M., "Actúan como 'la Juventud del Delegado'. Realizarán un acto 'los demetrios', un esotérico grupo justicialista", en La Opinión, 28 de noviembre 1971.

412 Entrevistas a Arturo Armada, C.A.B.A., 15/12/2015 y 29/12/2015; “Testimonio de Horacio Luis González”, en Archivo Testimonial de la Biblioteca Nacional Mariano Moreno, Bs. As., 2015. Disponible en http:/trapalanda.bn.gov.ar/jspui/handle/123456789/15679; Caparrós, M., y Anguita, E., La Voluntad, Bs. As., Planeta, 2013, Tomo I, p. 32.

${ }^{413}$ El sexto número de Envido contiene un documento de AEP titulado "El frente de liberación Nacional". En el mismo, la agrupación se presenta como el "frente estudiantil" del MRP y afirma que formaba parte del Consejo Provisorio de la JP, que encabezaba en ese entonces Rodolfo Galimberti. Envido, № 6, julio 1972. Al poco tiempo, el MRP terminó ingresando a la JP Regionales - Montoneros y AEP a la JUP.

${ }^{414}$ Chambouleyron, I., La Lista, Bs. As., Liber Editores, 2014, p. 104.

${ }^{415}$ La revista Ciencia Nueva publicó 29 números entre 1970 y 1974. En sus páginas participaron Varsavsky, García y Sadosky, pero también otros profesionales con perfiles diferentes como Jorge Sábato, Mario Bunge o Gregorio Klimovsky. En esta revista era publicado con mucha frecuencia el sociólogo y antropólogo brasileño Darcy Ribeiro.

416 "El Consejo Tecnológico del Movimiento Nacional Justicialista", en Ciencia Nueva, N 18,18 de agosto 1972. 
Por otro lado, Bernetti, que además de su primera militancia católica había tenido un temprano acercamiento al peronismo de izquierda mediante su participación en Acción Revolucionaria Peronista (ARP) y en la revista Cristianismo y Revolución ${ }^{417}$, en los setenta ingresó a la estructura orgánica de la JP Regionales por su militancia en las Juventudes Argentinas para la Emancipación Nacional (JAEN). Como vimos, esta organización tuvo importancia en la conformación de los frentes de masas porque era liderada por Rodolfo Galimberti, en ese entonces representante juvenil en el Consejo Superior del MNJ. En 1973, el principal activismo de Bernetti fue en el Bloque de Prensa Peronista que integraba la JTP, el cual había surgido de la fusión de dos grupos que participaban en la Asociación de Periodistas: la Agrupación 26 de Julio y la Agrupación 26 de Enero, fundada por Bernetti junto a Dardo Cabo y Julio Bornic. Aunque su mayor visibilidad se dio durante las elecciones de marzo, al desempeñarse como vocero oficial de Cámpora dentro de la oficina de prensa del FREJULI, a cargo de Miguel Bonasso ${ }^{418}$.

Para finalizar, al último integrante de Envido que podemos nombrar por haber integrado la red de militancia vinculada a Tendencia es Horacio Fazio. Si bien al igual que Horacio González no provenía del MHR y el CAEH, sí era católico y había tenido una formación política inicial en los Grupos Marcha. A principios de los setenta, militó en los Comandos Estudiantiles Peronistas (CEP) de la Facultad de Ciencias Económicas y ya como graduado en los EPT de la JP Regionales. Luego de la asunción de Cámpora, fue designado secretario académico de esa casa de estudios, donde también dictó clases Fernández López, otro economista pero de origen marxista que formó parte del consejo de redacción en los primeros números de la revista hasta que lo reemplazó el mismo Fazio ${ }^{419}$. A esto hay que agregar que el propio Oscar Sbarra Mitre, quien fue designado decano interventor de Económicas, participó en el octavo número de Envido con una nota titulada: "Poder político popular y distribución del ingreso" ${ }^{240}$.

\section{III - UN PROYECTO PARA LA NUEVA UNIVERSIDAD}

Envido era una revista multifacética que incursionó en la política, la historia, la

\footnotetext{
${ }^{417}$ ARP fue fundada por Cooke en 1963 luego de su viaje a Cuba con la intención de generar una organización de cuadros que sea capaz de orientar al movimiento peronista hacia estrategias insurreccionales y armadas. Véase: Cersósimo, F., Envar El Kadri. Historias del peronismo revolucionario, Bs. As., Colihue, 2008, p. 193. En ARP participó Juan García Elorrio el director de Cristianismo y revolución. Bernetti fue el secretario de redacción de la revista. Se puede consultar especialmente el número dos y tres donde se muestra el staff. Cristianismo y revolución, $\mathrm{N}^{\circ}$ 2-3, octubre-noviembre 1966.

${ }^{418}$ Entrevista a Jorge Luis Bernetti, C.A.B.A, 06/02/2016; Bernetti, J., El peronismo de la victoria, Bs. As., Colihue, 2011.

${ }^{419}$ Entrevista a Horacio Fazio, C.A.B.A., 09/12/2015

${ }^{420}$ Envido, № 8, marzo 1973, pp. 25-43.
} 
arquitectura, la canción popular, el cine, la economía, la sociología y la salud mental, pero sobre todo fue una caja de resonancia de cuestiones universitarias. Como vimos, los principales integrantes de su staff estaban ligados al ámbito académico porteño, a lo que se sumaba que una buena parte de su distribución en el interior del país era posible por sus contactos con grupos estudiantiles, como el Integralismo de Córdoba, los Ateneos de Santa Fe y la Federación Universitaria de la Revolución Nacional (FURN) de La Plata. Aunque lo más importante en este aspecto, fue que desde sus primeros ejemplares publicó notas y documentos firmados por núcleos estudiantiles, docentes e intelectuales peronistas. Entre su segundo número de noviembre de 1970 y el sexto de julio de 1972, pueden encontrarse varias intervenciones, algunas que hacían más hincapié en lo político-universitario y otras más centradas en la coyuntura política. En relación a las primeras, no puede pasarse por alto el escrito de la Tendencia Popular de Arquitectura y Urbanismo (TUPAU) que indagaba las particularidades que adquiría su profesión en un país dependiente ${ }^{421}$ o las reflexiones de Argumedo y O'Farrell sobre los enfoques académicos y políticos de las $\mathrm{CN}^{422}$. Mientras en las notas más atentas a la situación del país y a las tomas de posición política, las firmas podían ir desde el Frente Estudiantil Nacional y la Organización Universitaria Peronista (FEN-OUP) hasta los CEP y la Fuerza para la Organización Revolucionaria Peronista (FORPE) que encabezaba en ese entonces "Chacho" Álvarez ${ }^{423}$. La tónica general de estos documentos y artículos era la crítica a la dictadura de Lanusse y la visión del peronismo como un movimiento de liberación orientado a la construcción del socialismo nacional.

Sin embargo, la discusión de la cuestión universitaria en Envido adquirió relevancia a partir de su séptimo número de octubre de 1972 titulado "Perón Vuelve" ¿Qué fue lo que empezó a ocurrir en ese momento previo al retorno del viejo líder exiliado para señalarlo como un punto de quiebre en relación a cómo se discutía el papel de la militancia peronista en la universidad y sus ideas en torno a los objetivos, la estructura y la organización de la misma? Desde fines de dicho año, los sectores estudiantiles y docentes peronistas que se integraron a la estructura de la recién creada JP Regionales bajo el liderazgo público de Galimberti y la conducción de Montoneros comenzaron hacer mayor hincapié en la necesidad de discutir las especificidades del mundo universitario. Esto lo reflejó la Declaración del

\footnotetext{
${ }^{421}$ TUPAU, "Arquitectura y dependencia", en Envido, $\mathrm{N}^{\circ}$ 2, noviembre 1970. Como vimos en el capítulo anterior la TUPAU era parte de CENAP, uno de los sectores estudiantiles peronistas que conformó la JUP en 1973.

${ }^{422}$ Argumedo, A., "Cátedras Nacionales: una experiencia peronista en la universidad", en Envido, № 3, abril 1971 y O'Farrell, J., "Mensaje a los compañeros”, en Envido, № 4, septiembre 1971.

${ }^{423}$ FORPE, "Sobre la guerra y el socialismo nacional", en Envido, $\mathrm{N}^{\circ}$ 5, marzo de 1972; FEN-OUP, "Primer cabildo abierto del peronismo universitario, en Envido, $\mathrm{N}^{\circ}$ 6, julio 1972 y CEP, "El frente de liberación nacional", en Envido, $\mathrm{N}^{\circ}$ 6, julio 1972.
} 
Congreso Nacional de Estudiantes Peronistas que apareció en el mencionado séptimo ejemplar de la revista. A este encuentro, asistieron grupos estudiantiles peronistas de Santa Fe, Corrientes, Paraná y Buenos Aires. Su pronunciamiento público manifestaba la necesidad de garantizar la retirada de la dictadura mediante la reorganización de la JP, el retorno de Perón a la Argentina y el respaldo a las organizaciones armadas. Pero lo más interesante era que resaltaba que para contribuir a dicho objetivo había que construir una "política universitaria peronista" enfocada en las demandas particulares de las casas de estudio y del estudiantado $^{424}$. Entre todas las agrupaciones del país que firmaron el comunicado, estaban presente AEP y los núcleos estudiantiles porteños que formaron a principios de los setenta la Coordinadora Universitaria Peronista (CUP). La columna vertebral de esta entidad que en el capítulo anterior caracterizamos como la proto-JUP, estaba compuesta por los grupos que más se referenciaron con las organizaciones armadas en ese entonces: la Corriente Estudiantil Nacional y Popular (CENAP), los CEP, la Federación de Agrupaciones Nacionales de Estudiantes Peronistas (FANDEP) y las Bases Peronistas de Derecho (BAPDE), que luego se extendieron a Económicas e Ingeniería.

De todas formas, la declaración del Congreso Nacional de Estudiantes Peronistas todavía no especificaba de qué manera se construiría esa política universitaria que proclamaba. A decir verdad, el verdadero cambio en este terreno recién se hizo posible a principios de 1973, con la elección de Cámpora como nuevo presidente y la constitución del frente de masas universitario de la JP Regionales, compuesto por la JUP y la ADUP. La creación de ambas organizaciones implicó no sólo la preocupación por prestar atención a las particularidades de la universidad que ya podía rastrearse con mayor o menor énfasis en años anteriores, sino la propuesta de un proyecto concreto para definir los fines, la estructura y la organización de las casas de estudio. Este asunto no pasó desapercibido en Envido. En el octavo número de marzo y el noveno de mayo de 1973, se publicaron tres propuestas para la nueva universidad firmados por ADUP, la FURN y la JUP, respectivamente. Estos documentos delimitaban un plan con una orientación política común, más allá de algunas particularidades de cada uno. El primero de ellos aclaraba en su portada que había sido elaborado por petición del propio Cámpora y los otros dos que habían sido diseñados con el propósito de generar políticas universitarias específicas para ser aplicadas por el nuevo gobierno peronista y tenidas en cuenta en la elaboración de una futura ley que reorganizara las

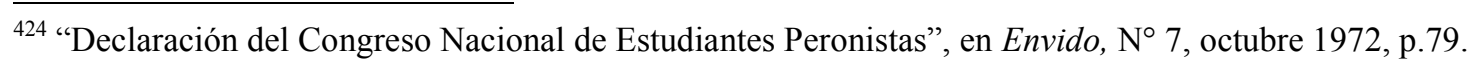


casas de estudio ${ }^{425}$

Sin embargo, dichos señalamientos se hacían sin dejar de sostener que el principal horizonte del peronismo era la construcción del socialismo nacional y la superación del "sistema liberal burgués". Como vimos en el capítulo anterior, cierta ambivalencia cruzaba a todos los frentes de masas de la JP Regionales, porque a la vez que se reconocían parte de un gobierno surgido en elecciones democráticas y se veían en la obligación de aportar cuadros y políticas para sus diversas áreas de trabajo, afirmaban públicamente que la verdadera "toma del poder" recién llegaría mediante la "guerra revolucionaria" y no a raíz de un proceso electoral. Este juego a dos puntas no debe llamar la atención si se tiene en cuenta que al calor del retorno del peronismo al gobierno, los propios Montoneros impulsaron la creación de grandes ámbitos de superficie en base a la unión de distintos sectores juveniles, con la intención de fortalecerse en el plano político-institucional y no sólo en el militar. Los tres artículos que nombramos eran sugestivos al respecto, sobre todo el de la JUP. Este aparte de funcionar como un decálogo de propuestas para la universidad y de resaltar la militancia en ese ámbito, nunca dejaba de exaltar la consigna de "guerra popular y prolongada" ${ }^{26}$. Además, lo interesante es que este documento fechado el 9 abril de 1973 fue su misma acta de constitución; la base programática que acordaron los distintos grupos estudiantiles que integraron la JUP, antes de su lanzamiento público el día 23 de ese mismo mes en la sede central del Partido Justicialista (PJ). El acta estaba refrendada por distintas agrupaciones del país, como el Movimiento Ateneísta de Santa Fe y la FURN de La Plata, pero la mayoría pertenecía al ámbito porteño. Estaban presentes las firmas de todos los integrantes de la CUP y de otros actores estudiantiles que ya nombramos en más de una oportunidad, como AEP y FORPE $^{427}$.

Más allá de esta ambivalencia, que demostraba el doble carácter que tuvieron ADUP y la JUP en un principio en tanto se consideraban pilares del gobierno electo y a la vez grupo de superficie de una estructura militar, ¿en qué consistía el proyecto para la nueva universidad que difundieron en Envido por ser una revista con llegada al ámbito académico y militante? El proyecto partía de un diagnóstico general: la universidad estaba en crisis al igual que el resto del país por los 18 años de democracias fraudulentas y golpes militares. Por esta razón,

\footnotetext{
425 ADUP, "Documento presentado por la Juventud Peronista al compañero Cámpora. Política universitaria", en Envido, N 8, marzo 1973, p. 60; FURN, "La nueva universidad: resumen de pautas para su implementación”, en Envido, N 9, mayo 1973, p. 53; JUP, “Juventud Universitaria Peronista”, en Envido, № 9, mayo 1973, p. 55. Para sintetizar la escritura, hacemos referencia al plan que delimitaron estos tres documentos como propuestas para la nueva universidad o proyecto para la nueva universidad.

${ }^{426}$ JUP, Ob. cit., mayo 1973, p. 54.

${ }^{427}$ Ibídem, p. 61. Como la FURN también integró la JUP, de ahora en adelante sólo nombraremos a JUP y ADUP para hacer referencia a las propuestas para la nueva universidad.
} 
argumentaban que la "reconstrucción nacional" debía ser acompañada por una "reconstrucción universitaria". Para la JUP y ADUP, ello sólo sería posible si se transformaba todo el sistema de educación superior en base a tres grandes ejes: el fortalecimiento del poder planificador del Estado; la reorganización de los métodos y contenidos de enseñanza; y el establecimiento de la gratuidad total y el ingreso irrestricto.

El primer punto era considerado central para garantizar que la formación de docentes, investigadores, técnicos y profesionales en las universidades sea puesta "al servicio" del desarrollo productivo, político y cultural de todas las regiones del país. La responsabilidad estatal en el diseño y control de los fines de la enseñanza superior era inalienable, pero esto no significaba quitarles incidencia en su definición a los actores específicos del campo académico y tampoco desconocer la intervención de otros sectores sociales. A su entender, la planificación tenía que terminar de definirse y consensuarse en un órgano de gobierno universitario compuesto por representantes de: a) el Ministerio de Educación para garantizar la articulación entre las políticas globales del Estado y las universidades; b) los claustros docentes, estudiantiles y no docentes para asegurar la participación de los protagonistas de la vida académica y respetar sus particularidades sectoriales; c) organizaciones populares o referentes territoriales no pertenecientes al Estado ni a la universidad capaces de brindar un encuadramiento social a la comunidad académica. Mediante esta propuesta, la JUP y ADUP buscaban una estructura que posibilitara ensamblar la comunidad universitaria, la sociedad y el Estado. Pero dentro de este esquema general, no dejaban de resaltar que era imperioso garantizar la participación política de los estudiantes y reconocer -por primera vez en la historia- el acceso de los no docentes al gobierno de las casas de estudio ${ }^{428}$.

La transformación del proceso pedagógico era la segunda propuesta de la JUP y ADUP. Esta implicaba una reorganización total de la formación superior a partir de tres áreas: una técnico-científica, una productiva y otra político-doctrinaria. La primera sería la encargada de orientar el desarrollo profesional, técnico y científico de acuerdo a las necesidades sociales y económicas de cada provincia argentina. Desde este enfoque, pretendían crear un sistema de promoción de carreras prioritarias y reemplazar el curso de ingreso tradicional por un ciclo introductorio común de un año, orientado a brindar un “Servicio de Información y Orientación Vocacional" para los ingresantes. El área productiva, por su parte, tendría la tarea de superar la disociación entre trabajo manual e intelectual en el proceso de aprendizaje. Este espacio debería incorporar a los estudiantes a actividades sociales y a ámbitos de producción vinculados a la formación de sus respectivas carreras, en

\footnotetext{
${ }^{428}$ ADUP, Ob. cit., marzo 1973, p. 62; FURN, Ob. cit., mayo 1973, p. 52; JUP, Ob. cit., mayo 1973, p. 69.
} 
estrecha articulación con los ministerios de Educación y Economía. La implementación de este régimen permitiría crear nuevos escenarios pedagógicos más allá del aula universitaria e introducir a otros actores sociales. Finalmente, el área político-doctrinaria era considerada como el ámbito de formación política de los estudiantes. La encargada de establecer en las facultades una serie de cursos en los cuales se abordara desde actualidad política hasta historia argentina y latinoamericana. Dichos encuentros, podrían ser dictados por profesores universitarios y por personas que no formaran parte del personal docente, pero que estuvieran capacitadas para impartir formación política y doctrinaria ${ }^{429}$.

El tercer punto importante del proyecto era el acceso gratuito y sin restricciones a la universidad. La propuesta de no cobrar ningún tipo de aranceles y de erradicar "trabas" como los exámenes de ingreso eliminatorios, estaba basada en la idea de que era responsabilidad del Estado concebir a la educación superior como un servicio social en favor de las clases populares. Para garantizar la incorporación de estos sectores, también sugerían otras medidas relevantes, como rentar el trabajo que el área productiva asignaría a los alumnos que no estaban en condiciones de financiar sus estudios y establecer un presupuesto que permitiera otorgar becas y remuneraciones adecuadas al personal docente y no docente. Además, proponían contrarrestar la excesiva extensión de algunas carreras y el alto porcentaje de deserciones mediante la creación de títulos intermedios. Todas estas medidas, como el mismo ingreso gratuitito e irrestricto, deberían combinarse con una política que, a través del ciclo introductorio y el curso de orientación vocacional del área técnico-científica, alentara el ingreso a carreras consideradas prioritarias ${ }^{430}$.

\section{ENTRE LA REFORMA Y EL PRIMER PERONISMO}

¿Por qué la JUP y ADUP sostenían en Envido que la nueva universidad debía erigirse en base a estas tres grandes orientaciones para contribuir desde su espacio particular a la reconstrucción nacional y a la futura instauración del socialismo en Argentina? A su entender, este proyecto no sólo era adecuado ante la crisis que vivían las casas de estudio, sino también porque buscaba resolver una problemática que permanecía abierta desde comienzos del siglo XX. Esta era caracterizada como el divorcio entre los universitarios y los movimientos nacional-populares. El drama supuestamente había comenzado después de 1918 cuando el reformismo fue abandonando progresivamente el espíritu “antioligárquico” y

\footnotetext{
${ }^{429}$ ADUP, Ob. cit., marzo 1973, pp. 60-61; FURN, Ob. cit., mayo 1973, pp. 51-52; JUP, Ob. cit., mayo 1973, p. 60

${ }^{430}$ ADUP, Ob. cit., marzo 1973, p. 61; FURN, Ob. cit., mayo 1973, p. 52; JUP, Ob. cit., mayo 1973, p. 60.
} 
"antiimperialista" que había compartido con el yrigoyenismo. Si al principio su demanda por la democratización interna de las casas de estudio había sido acompañada de otras reivindicaciones políticas que expresaban el avance de los sectores medios en el Estado, al poco tiempo diluyó su repertorio a la simple preocupación por el cambio de estatutos universitarios. Para la JUP y ADUP, esta desconexión entre la cuestión universitaria y la nacional había terminado por desvirtuar el papel progresivo del movimiento reformista, tal como habría quedado demostrado cuando impulsó el derrocamiento de Hipólito Yrigoyen en 1930. Además, señalaban que pese a los llamados de FORJA, los universitarios no pudieron superar esa visión política distorsionada en los años siguientes. Así, se opusieron desde el principio al peronismo cuando este anuló la autonomía universitaria, sin contemplar la mejora socioeconómica de la clase trabajadora, ni los avances conseguidos en la educación superior, como la supresión de aranceles, la creación de residencias estudiantiles, el aumento del presupuesto universitario, las becas y la creación de la Universidad Obrera Nacional $(\mathrm{UON})^{431}$

El relato histórico de la JUP y ADUP daba a entender que su proyecto para la nueva universidad recién pudo materializarse cuando la comunidad académica logró superar ese viejo desencuentro representado metafóricamente en los años del primer peronismo en la consigna “alpargatas sí, libros no". Según los estudiantes y docentes de la izquierda peronista, este proceso había comenzado a fines de los cincuenta cuando los universitarios empezaron a cuestionar la política "cientificista" y "desarrollista" del gobierno de Arturo Frondizi. Pero a su entender, el verdadero cambio había llegado con la intervención de 1966. Esta afirmación no era para nada novedosa y hasta podría decirse que era el sentido común de buena parte del peronismo universitario de los años sesenta y setenta. Era la idea recurrente de que la represión de Onganía sobre la universidad no había hecho más que introducir la "realidad del país" en la "isla democrática". Dicho en otros términos, la propia JUP y ADUP volvían a poner en primer plano la concepción de que la peronización de estudiantes, docentes e intelectuales se debía en gran parte a que la dictadura había extendido la proscripción política que vivía el peronismo al interior de las universidades. A su entender, el intento despolitizador de los claustros no había hecho más que acercar a los trabajadores y universitarios a un terreno común que contribuyó a identificarlos políticamente. Dicha conexión habría terminado de afianzarse con el Cordobazo en 1969 y las otras revueltas

\footnotetext{
${ }^{431} \mathrm{Si}$ bien los tres documentos tienen referencias históricas, el de la JUP hace un relevamiento ordenado de la situación política y universitaria entre 1918 y 1973. El mismo delimita tres etapas: "La Reforma Universitaria de 1918", "La Universidad en la segunda Década Infame” y "La Universidad de la Revolución Argentina". JUP, Ob. cit., mayo 1973, pp. 55-58.
} 
populares en el interior del país que marcaron el comienzo del fin de la Revolución Argentina $^{432}$. El recorrido trazado por la JUP y ADUP no era casual, pretendía dar a entender que su proyecto para la nueva universidad sería el que coronaría en el plano de la educación superior el encuentro entre dos actores políticos que habían marchado por carriles opuestos durante muchos años.

Como toda visión política del pasado que pretende auto-justificarse y resumir en unas pocas líneas una gran secuencia histórica, el relato de JUP y ADUP incurría en simplificaciones y generalizaciones. Sin embargo, su retrospectiva y las propuestas publicadas en Envido mostraban que el discurso universitario del peronismo de izquierda carecía de linealidad y tenía un carácter zigzagueante. Lo primero que sobresale es que no retomaban la tónica de los últimos números de Antropología 3er. Mundo. Como vimos en el segundo capítulo, la última etapa de esta publicación reflejó la voz de los grupos estudiantiles y docentes peronistas que a principios de los setenta habían exaltado los cuerpos de delegados, la "muerte del reformismo" y la crítica radical al sistema educativo, en consonancia con otros sectores maoístas como FAUDI y TUPAC que se expresaban en la revista Los Libros $^{433}$. Esta cuestión es relevante si se tiene en cuenta que la columna vertebral de la JUP en la UBA estaba compuesta por aquellos núcleos militantes peronistas que más se habían referenciado en el discurso de esos organismos de base, sobre todo durante 1971 en las facultades de Arquitectura y Filosofía y Letras. Sin embargo, tan sólo dos años después, en medio de la algarabía por el triunfo electoral y el retorno del peronismo al gobierno, el frente universitario de la JP Regionales se apartó de ese antecedente inmediato y volvió a poner el foco en una concepción surgida en los primeros números de Antropología 3er. Mundo, donde artículos como el de Cárdenas o el del propio director de la revista habían esbozado un relato destinado a promover y legitimar la presencia del peronismo en la universidad ${ }^{434}$. Esta perspectiva resaltaba la necesidad de construir una articulación virtuosa entre ese movimiento y los sectores medios, sobre la base de una política que hiciera hincapié en las demandas específicas de los universitarios y reconociera antecedentes valiosos tanto en la Reforma como en los primeros gobiernos de Perón.

La JUP y ADUP fueron más allá en 1973 y desde las páginas de Envido tradujeron ese

\footnotetext{
${ }^{432}$ Se puede consultar sobre todo el apartado "La Universidad de la Revolución Argentina" que nombramos en la cita anterior. Ibídem, p. 58.

${ }^{433}$ Véase en el capítulo dos, los documentos: "CEP evalúa la experiencia del cuerpo de delegados de Filosofía y Letras", en Antropología 3er. Mundo, № 8, septiembre-octubre 1971; "El movimiento estudiantil: de la Reforma al Cordobazo", en Los Libros, $\mathrm{N}^{\circ} 21$, noviembre 1971.

${ }^{434}$ Cárdenas, G., "El movimiento nacional y la universidad", en Antropología 3er. Mundo, № 3, noviembre 1969; Gutiérrez, G., "Pensamiento nacional y política”, en Antropología 3er. Mundo, N 4, septiembre 1970.
} 
relato preliminar en un proyecto concreto para definir los fines, la estructura y la organización de las casas de estudio. Pero lo hicieron sin abandonar ese primer "anhelo revisionista" que esbozó Antropología 3er. Mundo en relación a los dos grandes momentos de la historia universitaria de nuestro país que nombramos anteriormente. Ya afirmamos, a partir de Raymond Williams, que todos los actores sociales justifican sus nuevas prácticas y propuestas desde una visión de los sucesos históricos precedentes, en la cual algunos hechos o significados son acentuados y otros invisibilizados ${ }^{435}$. Así ocurrió también en el momento en que los universitarios de la JP Regionales explicaron su presencia militante en las casas de estudio y su proyecto para transformarlas. Su relato retomaba la política de democratización social de las universidades que había llevado adelante el peronismo al establecer la gratuidad y otras medidas destinadas a fomentar el ingreso de trabajadores y nuevos sectores medios. También destacaba su intento de planificar la enseñanza superior atendiendo las necesidades productivas del país al crear la UON. Pero lo que no abordaban ni revisaban la JUP y ADUP en su retrospectiva histórica era la escaza capacidad de los gobiernos de Perón de crear una articulación política eficaz con los estudiantes, docentes e intelectuales que poblaban las casas de estudio. Sus dos leyes universitarias habían subordinado a las mismas al poder ejecutivo y otorgado una nula participación política al estudiantado en los órganos de gobierno ${ }^{436}$; a ello se sumaba que la constante exaltación de aspectos políticos y doctrinarios no había hecho más que profundizar la brecha que separó desde un principio a buena parte de la militancia universitaria, como lo había señalado el propio Rosa en la revista Envido ${ }^{437}$.

Lo destacable era que la JUP y ADUP pretendían vincular el afán socialmente democratizador y planificador del primer peronismo con el protagonismo de los claustros en los ámbitos de toma de decisiones de la universidad, reclamando con énfasis un lugar importante a los estudiantes e incorporando novedosamente a los no docentes. En este punto, puede decirse que se alejaban del discurso de la "muerte de la Reforma" y retomaban la evaluación que FORJA había hecho de la misma en el manifiesto que dedicaron a los estudiantes de la UBA en 1943. ¿Cuál era la tesis principal de este documento conocido en el ambiente porteño de principios de los setenta gracias a que Antropología 3er. Mundo lo había reproducido en su cuarto ejemplar? Su afirmación más importante era que los reformistas habían "desvirtuado" el sentido inicial de la Reforma al privilegiar solamente la autonomía

\footnotetext{
${ }^{435}$ Williams, R., Marxismo y literatura, Bs. As., Las Cuarenta, 2009, p. 153.

${ }^{436}$ En el capítulo dos, ya analizamos la política de democratización social del peronismo y sus dos leyes universitarias: la 13.031 y la 14.297.

${ }^{437}$ Saravi, T., "Reportajes Biográficos: José María Rosa”, en Envido, № 2, noviembre de 1970, pp. 40-51.
} 
universitaria y desconocer la demanda central del Manifiesto Liminar ${ }^{438}$. Ésta no era otra que garantizar la participación política del estudiantado en el gobierno de la universidad y su presencia crítica en la cátedra, ya que su activismo permitía vincular la problemática universitaria con cuestiones sociales y políticas más amplias. La JUP y ADUP recurrieron a dicha lectura para resaltar sus críticas al viejo distanciamiento de reformistas y peronistas, pero también para apropiarse de ciertas reivindicaciones que el primer peronismo no les podía ofrecer. A decir verdad, FORJA era la correa de transmisión que les permitía conectar la Reforma con el peronismo. No sólo legitimaba la prédica del activismo político del movimiento estudiantil, sino que también proporcionaba un discurso que llamaba a superar la escisión entre pueblo e intelectuales, a través de la generación de instancias de complementación entre la universidad, el Estado, la economía y la sociedad ${ }^{439}$.

\section{UN HERVIDERO DE DISCURSOS SOBRE LA UNIVERSIDAD}

Desde ya que no era exclusivo de la izquierda peronista este esfuerzo por revisar la historia de la universidad y plasmar una serie de propuestas para transformarla. Todo el período 1972-73 fue un hervidero de discursos sobre cómo encarar la cuestión universitaria. Si se hace un repaso por diarios, revistas, libros y documentos de ese entonces, se puede encontrar un sinfín de personalidades opinando sobre este tema. Estudiantes, docentes, intelectuales y hasta funcionarios y políticos de diversos orígenes y posturas coincidían en que la universidad estaba en crisis y era imperioso modificarla. Las diferencias surgían cuando se diagnosticaban las causas del problema y las soluciones a seguir. Para resaltar las particularidades de la JUP y ADUP, es interesante contraponer su proyecto con el de otros dos actores que también recurrieron a una lectura retrospectiva de la Reforma y el peronismo. El primero era la Concentración Nacional Universitaria (CNU), organización que había surgido en La Plata en 1965 bajo la guía intelectual de Carlos Disandro, pero que comenzó a ser reconocida públicamente a fines de 1971 con el asesinato de la estudiante Silvia Filler en Mar del Plata ${ }^{440}$. Reconociéndose peronista, la CNU tenía una lectura y una orientación ideológica muy diferente a la de JUP y ADUP. En agosto de 1972, publicó un boletín titulado Ley 13031

\footnotetext{
438 “FORJA y la Universidad", en Antropología 3er.Mundo, No 4, septiembre 1970, p. 65. El nombre original de este documento publicado en junio de 1943 es "Manifiesto de FORJA a los estudiantes de la Universidad de Buenos Aires". El mismo será reeditado nuevamente en 1974 en la revista Crisis. Véase: Crisis, No 11, marzo 1974.

439 Dip, N., "El peronismo universitario en un mundo de tensiones. Una aproximación al itinerario de las organizaciones de estudiantes y docentes peronistas de los años sesenta a través del estudio del proyecto de Universidad Nacional-Popular propuesto en la revista Envido", en Nuevo Mundo Mundos Nuevos, 2013.

${ }_{440}$ Carnagui, J.L., Nacionalistas, católicos y peronistas. Auge, afianzamiento y reconfiguración de la Concentración Nacional Univeristaria (CNU) La Plata, 1955-1974, Tesis de Doctorado, FaHCE-UNLP, 2015.
} 
del 47 que estaba firmado por distintos grupos que la integraban, entre los que se encontraban el Sindicato Universitario de Ingeniería de la UBA. El documento señalaba que la decadencia de las universidades había surgido con el "sentido antinacional" de la Reforma de 1918. Esta experiencia era considerada como una extensión local de la Revolución Rusa y negada por haber introducido un factor conflictivo con el establecimiento de "soviets" de estudiantes, profesores y graduados. A su entender, la única solución para la universidad era retornar al “espíritu nacional” de la ley 13.031. La restauración de esta normativa, que había sancionado el primer gobierno de Perón en 1947, sería suficiente para “normalizar" y encauzar a las casas de estudio, al subordinar sus autoridades al poder ejecutivo, eliminar el cogobierno, garantizar la conducción universitaria del claustro de profesores y desterrar la "politiquería"441 . Como vemos, la divergencia entre la CNU y la JUP-ADUP puede comprenderse no sólo porque unos levantaban la consigna de la "patria peronista" desde una perspectiva antimarxista y otros la del "socialismo nacional", sino por sus distintas maneras de significar la crisis universitaria de los setenta y sus antecedentes más importantes.

El otro actor que no puede pasarse por alto para entender las particularidades del proyecto para la nueva universidad difundido en las páginas de Envido, es el Movimiento de Orientación Reformista (MOR). Ya observamos en el segundo capítulo que el brazo estudiantil del PC se impuso ampliamente en las elecciones estudiantiles celebradas en la UBA a fines de 1972. En contraste con las agrupaciones de la izquierda maoísta que reivindicaban la "muerta de la Reforma", el MOR seguía afirmando su plena actualidad y vigencia. Es más, si la CNU expresaba la tesis de la "restauración peronista" en la universidad, los comunistas eran su contracara reformista. En un documento de 1972 firmado por la Comisión Nacional Universitaria del PC eran claros al respecto. A su entender, la universidad sólo podría superar su crisis interna si se garantizaban la autonomía, el gobierno tripartito y la calidad científica de la enseñanza ${ }^{442}$.

Aunque es importante aclarar que los comunistas argentinos no fueron los únicos que defendieron esta tesis y que el debate sobre la cuestión universitaria en los setenta tuvo incluso un alcance regional. A fines de ese mismo año, la revista Ciencia Nueva publicó en la tapa de su decimonoveno número la "mesa redonda" sobre crisis universitaria latinoamericana que compartieron el chileno Arturo Jadresic Vargas, el uruguayo Oscar Maggiolo, el brasilero Darcy Ribeiro y los argentinos Fernando Storni y Risieri Frondizi, en el Centro Cultural

\footnotetext{
${ }^{441}$ CNU, "LEY 13031 del 47”, agosto 1972. Disponible en CPM. Archivo de la ex-DIPBA, Mesa A, Leg. $\mathrm{N}^{\circ} 154$, Foja 16.

${ }^{442}$ Comisión Nacional Universitaria del PC, "Seis años de dictadura: por una solución democrática, popular y antiimperialista para la universidad y el país", 29 de julio 1972.
} 
General San Martín de la Municipalidad de Buenos Aires ${ }^{443}$. En ella, el antiguo rector de la UBA sostuvo una postura similar a la del MOR. Para Frondizi, el colapso de las universidades que produjo el golpe de Onganía en 1966 y la situación crítica de todas las casas de estudio de la región, podía ser remediado con dos medidas reformistas clásicas que el mismo había señalado en 1971 en su libro La Universidad en un mundo de tensiones. Éstas no eran otras que la autonomía y la libertad de cátedra. Desde su perspectiva, era imperioso garantizar a las unidades académicas la capacidad de dictar sus propias normas y a los profesores la independencia para difundir la concepción pedagógica y científica que consideren más adecuada. Estas "grandes libertades" eran necesarias porque las universidades y las cátedras estaban integradas por los hombres de "mayor jerarquía intelectual”, por esta razón no precisaban ni guías ni tutores “ajenos" que las controlen. No obstante, en consonancia con los aires de cambio de los setenta, Frondizi también aclaraba que dichas libertades debían ser entendidas como un derecho que obligaba a los universitarios a comprometerse con la transformación de la estructura socio-económica y a orientar su formación científica, profesional y técnica de acuerdo a las necesidades del país ${ }^{444}$.

La postura de la JUP y ADUP tenía una visión crítica del reformismo y sobre todo de la autonomía universitaria que seguían reivindicando con énfasis el MOR y el propio Frondizi. Pero su orientación era muy lejana al discurso de la CNU. A decir verdad, las medidas anti-reformistas del primer peronismo que valoraba la organización de Disandro, como la prohibición de la política y la clausura del cogobierno universitario, eran invisibilizadas por la JUP y ADUP. Su relato hacía énfasis en otras políticas de los gobiernos de Perón y su plan de gestión universitaria difundido desde Envido era más bien un intento de combinar el papel planificador del Estado con la intervención política de todos de los claustros, incluidos estudiantes y no docentes.

De todas maneras, tampoco está demás aclarar que esta postura no era un invento propio y tenía como referente importante a Darcy Ribeiro, el sociólogo y ex militante del PC brasileño que había participado junto a Frondizi, Maggiolo, Storni y Jadresic Vargas en la mesa de debate organizada por Ciencia Nueva. Ribeiro combinaba varias características que lo hacían atractivo para los universitarios de la izquierda peronista, a los que conocía personalmente por las relaciones que había entablado con algunos docentes de las $\mathrm{CN}$ en años

\footnotetext{
$\overline{{ }^{443} \text { La actividad fue organizada el } 1}$ de agosto de 1972. Véase: "Mesa Redonda. La Universidad en América Latina", en Ciencia Nueva, № 19, octubre 1972.

${ }^{444}$ Frondizi, R., La universidad en un mundo de tensiones. Misión de las universidades en América Latina, Bs. As., Eudeba, 2005 [1971], pp. 318-322.
} 
anteriores $^{445}$. A su prestigio académico internacional por sus estudios antropológicos, sumaba una extensa trayectoria en gestión universitaria que había comenzado en Brasil durante las presidencias de Juscelino Kubitschek y Joao Goulart, y continuado en distintos países de América Latina luego del golpe de Estado de 1964 que lo forzó al exilio; entre los que se destacaba su asesoramiento al gobierno de Salvador Allende en Chile. Toda esta experiencia quedó plasmada en dos libros que se editaron en Argentina. El primero lo publicó Galerna en 1967 bajo el título La universidad necesaria, mientras el segundo apareció en 1973 con el título La universidad nueva. Un proyecto, cuya edición estuvo a cargo del sello Ciencia Nueva que también editaba la revista homónima ${ }^{446}$.

¿Por qué decimos que Ribeiro era un referente para la izquierda peronista? Porque su discurso sobre universidad reforzaba la idea de crear un compromiso activo contra la “dependencia científico-técnica" de los países centrales, a partir de una política universitaria capaz de planificar la relación entre la educación superior, la comunidad, el gobierno y sus distintas áreas. A ello sumaba su prédica por complementar la función científico-académica con la exigencia de una "universidad popular y masiva" donde no sólo concurrieran los sectores medios y altos ${ }^{447}$. Por otra parte, Ribeiro seguía visitando la Argentina en 1973. El 25 de marzo de ese mismo año, el diario La Opinión recogió algunas declaraciones suyas antes de la presentación de su libro La universidad nueva. Un proyecto. En ellas, dejó entrever algunas afirmaciones que no pasaban desapercibas en el contexto expectante de refundación que producían la retirada militar y el triunfo peronista. La más importante de todas era que a su entender el "gran mérito" de los argentinos radicaba en su conciencia sobre la crisis de la universidad. En este punto, advertía a modo de recomendación que era central que "los estudiantes no sólo tengan planes para transformar el país, sino también la universidad". Además, que era imperioso que participaran en el gobierno universitario ya que su presencia era la "única garantía" de cambio, al estar "demasiado comprometidos" los cuerpos académicos y los funcionarios con el statu quo ${ }^{448}$.

Como vemos, la postura de Ribeiro era funcional al intento de la JUP y ADUP de reforzar su presencia militante en las casas de estudio y su posición en el nuevo gobierno

\footnotetext{
${ }^{445}$ Según Argumedo, en ese entonces tenían contactos frecuentes con Ribeiro e incluso él había participado como invitado en la materia Nación y Estado que encabezó O'Farrell. En el segundo capítulo, señalamos que esta asignatura fue la última que dictaron las CN en 1971. Entrevista a Alcira Argumedo, C.A.B.A., 01/11/2012.

${ }^{446}$ Para un análisis de la recepción de las obras de Ribeiro en Argentina, se puede consultar: Celentano, A., "De la universidad necesaria a la universidad nueva: la recepción argentina de las tesis de Darcy Ribeiro entre 1967 y 1973”, en VII Jornadas de Sociología de la UNLP, La Plata, 2012.

${ }^{447}$ Darcy, R., "Repensando la universidad", en La universidad nueva. Un proyecto, Bs. As., Ciencia Nueva, 1973, pp.75-156.

448 “La universidad en el cambio revolucionario. Una investigación del antropólogo brasileño Darcy Ribeiro", en La Opinión, 25 de marzo 1973.
} 
peronista con la difusión de un proyecto de universidad en la revista Envido, el cual volvía a resaltar una y otra vez que la militancia específica en ese ámbito era esencial para contribuir a la "reconstrucción nacional" y a la instauración del socialismo. Sin dejar de aclarar, desde ya, que la "verdadera toma del poder" llegaría con la "guerra revolucionaria".

\section{IV - Peronistas Que PIENSAN Y GobIERNAN LA UNIVERSIDAD}

La revista que dirigió Armada no tuvo una vida muy larga. Envido sólo publicó diez números en todo su recorrido y a fines de 1973 terminó su empresa editorial. Pero la trayectoria de los principales integrantes de su staff demuestra que fue una clara expresión de la opción por el peronismo de izquierda de numerosos contingentes universitarios porteños. Sus discusiones políticas, culturales, científicas y profesionales que ponían en primer plano la cuestión de la dependencia y el socialismo nacional mostraban los múltiples cruces del campo político y universitario de esos años. Aunque nunca se presentó como una publicación orgánica de una agrupación política, el itinerario de Envido evidenció una fuerte identificación de su colectivo con la Tendencia Revolucionaria, el conglomerado político que terminó de conformarse bajo la hegemonía de la JP Regionales y Montoneros, al calor del retorno de Perón a la Argentina, el triunfo electoral del FREJULI y la asunción de Cámpora.

Desde esta ubicación y en este contexto complejo, la revista funcionó como un espacio de discusión de la cuestión universitaria. Sus páginas fueron un canal privilegiado para que los estudiantes, docentes e intelectuales que terminaron enrolados en la JUP y en ADUP, tramaran y difundieran un discurso que por primera vez presentaba un decálogo de medidas concretas para transformar los fines y la estructura de las casas de estudio. Las propuestas para la nueva universidad de estas dos organizaciones que funcionaron como el frente de masas universitario de la JP Regionales, tenían su punto de irradiación en Envido y formaban parte de una red más amplia de revistas, diarios, libros y editoriales donde un conjunto de actores de diverso signo político diagnosticaba la crisis de la universidad argentina y sugería distintas recetas para solucionarla.

Toda esta experiencia muestra otra arista importante de la peronización universitaria porteña. En capítulos anteriores, afirmamos que no se trató de un proceso general, sino de un itinerario orientado a la izquierda que adquirió magnitud a principios de los setenta y terminó siendo canalizado por agrupaciones como la JUP y la ADUP. Si ahora consideramos el proyecto de universidad publicitado en Envido, podemos sostener que la peronización implicó un fenómeno doble. Por un lado, fue un complejo camino a través del cual estudiantes, docentes e intelectuales procedentes de sectores que habían sido opositores al peronismo 
finalmente lo asumieron como su propia identidad política, aunque desde una perspectiva revolucionaria acorde a los relatos de los años sesenta y setenta. Pero por otra parte, también significó una nueva forma de pensar el papel de la universidad. El peronismo tenía que superar los viejos años de desencuentro para legitimar su presencia en las casas de estudio. Por esta razón, ya no podía caracterizar a la universidad como una "isla democrática" que daba la espalda al peronismo, sino que debía bosquejar una perspectiva capaz de reconocerla como un espacio legítimo de militancia en pos de la tan mentada construcción del socialismo nacional.

Si se toma como referencia el lapso temporal que comprende el pase de los sesenta a los setenta, no puede desconocerse que el discurso del peronismo de izquierda en torno a la cuestión universitaria careció de linealidad y tuvo un carácter zigzagueante. El itinerario que va desde Antropología 3er. Mundo hasta Envido no implicó un discurso monocorde y atravesó distintas experiencias políticas. No obstante, la constitución de JUP y ADUP en 1973 no sólo permitió aglutinar a la mayor parte del peronismo universitario, sino que también posibilitó delinear un proyecto alternativo para la gestión de las casas de estudio. Pedro Krotsch caracteriza a los años setenta como una época en la cual surgieron intensas propuestas para transformar la educación y la universidad, donde se exaltaban las ideas de "planificación" y "revolución" "449. Lo interesante del discurso de la JUP y ADUP radica en que acudían a esos conceptos pero sin dejar de establecer una mirada retrospectiva sobre la Reforma de 1918 y el primer peronismo; lo cual demuestra la importancia que tuvieron esas dos experiencias en el debate de los setenta y que el anhelo de construir una "universidad nueva" estaba anclado en la coyuntura particular de ese momento, pero también en una historia político-universitaria más amplia que se remonta a toda la primera mitad del siglo $\mathrm{XX}$.

De todas maneras, las propuestas de JUP y ADUP son inentendibles sin la referencia a 1973. Hay que recordar que los documentos publicados en Envido afirmaban explícitamente que habían sido diseñados con el propósito de contribuir a la política universitaria del nuevo gobierno peronista y a la elaboración de una futura ley universitaria. En el capítulo anterior, señalamos que a pesar de su gran protagonismo en el retorno de Perón y en la campaña electoral, la izquierda peronista estuvo lejos de llevarse la mejor parte en el reparto de cargos políticos nacionales y provinciales. Sin embargo, en la UBA pudo hegemonizar los espacios

\footnotetext{
${ }^{449}$ Krotsch, P., "Los universitarios como actores de reformas en América Latina ¿han muerto los movimientos estudiantiles?", en Carli, S. (dir.), Universidad pública y experiencia estudiantil. Historia, política y vida cotidiana, Bs. As., Miño y Dávila, 2014, p.149.
} 
de gestión, gracias a la designación de Puiggrós como rector-interventor y al nombramiento de una serie de funcionarios que formaban parte de los frentes de masas de la JP Regionales o eran integrantes del conglomerado más amplio de la Tendencia. Lo tratado en todos estos apartados, hace pensar que a la izquierda peronista no sólo se le reconoció ese protagonismo por su peso militante en la casa de estudio porteña, sino porque fue capaz de elaborar una propuesta política concreta para darle un sentido a la intervención de las universidades. Este proyecto fue reconocido desde un primer momento y el propio Cámpora lo hizo suyo en el mensaje que dirigió a la asamblea legislativa el mismo día de su asunción como presidente. A pesar de que su discurso hacia una exaltación de la "libertad de enseñanza" que no compartían los estudiantes y docentes de la Tendencia ${ }^{450}$, el mandatario electo retomaba las ideas centrales del proyecto para la nueva universidad publicitado en Envido. Sobre todo cuando afirmaba que la tarea de la universidad era acabar con la dependencia cultural y que era necesario superar las viejas antinomias como "reforma / anti-reforma", "gobierno estudiantil / gobierno de claustros" y "autonomía universitaria / dependencia de gestión". A su entender y en consonancia con la izquierda peronista, esto sólo sería posible si la universidad era capaz de combinar la participación de todos sus componentes - estudiantes, docentes, no docentescon mecanismos de representación de la comunidad e instancias orientadoras del Estado ${ }^{451}$.

Si se tiene en cuenta esta perspectiva sobre la organización de la universidad, tampoco resulta extraño que incluso sectores no peronistas hayan brindado desde el inicio un apoyo crítico al gobierno de Cámpora y a la propia gestión de Puiggrós. Ya comentamos en el capítulo anterior, que cuando el ministro Taiana invistió a este último en su cargo de rector interventor el 30 de mayo de 1973, concurrieron al acto dirigentes de FUA La Plata y de la FUBA. En presencia de ellos, el propio Puiggrós sostuvo que esperaba contar no sólo con el apoyo de peronistas, sino con el de todos los que compartían la idea de liberación. Lo relevante era que este llamado a la convergencia estaba dado por algo más que una simple interpelación por compartir un horizonte político común. El acercamiento de las dos federaciones que en ese momento seguía encabezando el MOR, se explica en buena medida por la forma en que Puiggrós encaró la cuestión universitaria desde el inicio de su mandato. Unos días después de su asunción, respondió un breve cuestionario en la revista Panorama que era sugestiva al respecto. El mismo se llamaba "Actualidad de la Reforma Universitaria"

\footnotetext{
${ }^{450}$ Bernetti muestra muy bien esta diferencia. Mientras Cámpora aseguraba en su discurso inaugural que no habría monopolio estatal de la enseñanza, la JUP y ADUP sostenían en sus planes que se iría progresivamente hacia un predominio de lo público. Bernetti, J., Ob. cit., 2011, p. 119.

${ }_{451}$ "Mensaje ante la Asamblea Legislativa. 25 de mayo de 1973", en Cámpora, H., La revolución peronista, Bs. As., Eudeba, 1973, p. 151.
} 
y estaba compuesto por tres preguntas: “¿Es actual la Reforma?” ¿Sirve o no sirve?” ¿Hay que actualizarla?". Su respuesta era interesante porque a pesar de que consideraba que la Reforma como un "todo" había perdido su vigencia, sostenía que eso no significaba negar que algunos de sus postulados pudieran ser recogidos, desarrollados y llevados a la práctica. Y como si esto fuera poco, afirmaba que la misma "idea peronista" de otorgar a la universidad una función junto al pueblo ya estaba presente en los proyectos reformistas de 1918, aunque nunca había podido convertirse en plena realidad ${ }^{452}$.

En este punto, Puiggrós parecía compartir la actitud "revisionista" que habían encarado la JUP y ADUP desde las páginas de Envido y retomado el propio Cámpora en su mensaje de asunción. Como vimos, los actores de la época traían a colación recurrentemente la idea de crear una "universidad nueva". Pero a decir verdad, lo que el proceso de peronización terminó gestando fue un nuevo peronismo en la universidad ¿Dónde radicaba lo nuevo? la novedad residía no sólo en su prédica a favor del socialismo nacional y la revolución, sino en su intento de superar viejos enfrentamientos y revisar distintos legados para proponer una política universitaria que fuera acorde a la realidad argentina de los años setenta. Esta actitud fue la que le permitió a ese peronismo iniciar una gestión que recibió el visto bueno de las agrupaciones reformistas y la que incluso posibilitaría, en meses posteriores a la asunción de Puiggrós, que la JUP se presentara a las elecciones de centros de estudiantes y participara en la disputa por la conducción de la FUBA, la federación que en otros tiempos había sido uno de los símbolos del antiperonismo.

\footnotetext{
452 “Actualidad de la Reforma Universitaria”, en Panorama, 14 de junio 1973. También se puede encontrar en Puiggrós, R., La universidad del pueblo, Bs. As., Ediciones de Crisis, 1974, p. 49.
} 


\section{PARTE III || CAPÍTULO V}

\section{EL AUGE Y OCASO DE LA PERONIZACIÓN PORTEÑA}

\section{De Puiggrós a la Ley Taiana}

1973 - 1974

En este quinto capítulo analizamos los posicionamientos de los grupos estudiantiles, docentes e intelectuales que se identificaron con el peronismo de izquierda en el contexto políticoacadémico que abrió la elección de Héctor Cámpora como presidente y de Rodolfo Puiggrós como interventor de la UBA. Luego de una introducción referida al modo en que distintos actores de la época diagnosticaron la llegada de Puiggrós al rectorado y la refundación de la casa de estudio como la "Universidad Nacional y Popular de Buenos Aires", reconstruimos el respaldo que brindaron la JUP y ADUP a su gestión. A su vez, indagamos si el peronismo de aquel entonces congregó una adhesión importante en la población universitaria, teniendo en cuenta la participación de la JUP en las elecciones de centros de estudiantes. Por último, abordamos las controversias que surgieron en torno a la sanción de la Ley Taiana (20.654), con la intención de analizar los debates que entablaron la JUP y ADUP con otros sectores del peronismo, la izquierda y el radicalismo.

\section{I - LA REFUNDACIÓN UNIVERSITARIA}

El 29 de mayo de 1973, en el cuarto aniversario del Cordobazo, las universidades nacionales fueron intervenidas por el decreto 35 que rubricaron el flamante presidente Héctor Cámpora y su ministro de Cultura y Educación, Jorge Alberto Taiana. La normativa del ejecutivo fundamentaba la decisión en la necesidad de superar la "crisis" que atravesaban las casas de estudio. En sus argumentos, se señalaba que esa situación era producto de la "dependencia" que sufría el país y de la represión de "todo tipo de disconformismo" manifestado por estudiantes, docentes y no docentes en años anteriores. Por esta razón, la medida establecía un "régimen transitorio de gobierno" hasta que pudiera establecerse un nuevo ordenamiento legal que definiera los objetivos y sentara las bases de la "reconstrucción universitaria", la cual tenía que estar al "servicio del pueblo" y contar con la participación de 
todos los sectores vinculados a la vida académica ${ }^{453}$. Para iniciar este camino, Cámpora sancionó el mismo 29 de mayo el decreto 37 con el que designó a los primeros cuatro interventores universitarios de su gestión: Rodolfo Agoglia en la Universidad Nacional de La Plata, Adolfo López Domínguez en la Universidad del Litoral, Víctor Benamo en la Universidad del Sur y Rodolfo Puiggrós en la Universidad de Buenos Aires. Desde ese momento, el poder ejecutivo les atribuyó las funciones que los estatutos otorgaban al rector y al consejo superior, con la finalidad de administrar transitoriamente las casas de estudio hasta que fuera aprobada la nueva ley universitaria ${ }^{454}$.

En el caso de la universidad porteña, Taiana invistió a Puiggrós en el cargo al día siguiente de sancionados los decretos. Su asunción fue recibida con expectativas por una parte importante del movimiento estudiantil, el cual ostentaba una gran presencia política por haber sido uno de los principales opositores al régimen militar saliente. Poco tiempo antes de su nombramiento, sectores peronistas y de izquierda habían participado de movilizaciones y ocupaciones de establecimientos, en reclamo de que ningún funcionario de la dictadura continuara en cargos de gestión. En la jornada de investidura de Puiggrós tuvo un papel protagónico la Juventud Universitaria Peronista (JUP), aunque tampoco estuvieron ausentes militantes enrolados en la Federación Universitaria de Buenos Aires (FUBA). En su discurso inaugural, el flamante mandatario señaló que el retorno del peronismo al poder abría otra etapa para el país y la posibilidad de crear una "nueva universidad" con todos los que compartían el horizonte de "liberación" y el camino hacia el "socialismo nacional"455 . La presencia destacada del activismo estudiantil y la tónica politizada que convocaba a una refundación universitaria, se repitió en la toma de posesión de los delegados interventores que nombró Puiggrós en cada una de las facultades de la que pasó a llamarse de hecho como la “Universidad Nacional y Popular de Buenos Aires" (UNPBA).

No todos recibieron con entusiasmo este nuevo panorama de la casa de estudio porteña. El tradicional diario La Prensa, que tenía una histórica confrontación con el peronismo e incluso el antecedente de haber sido expropiado por el primer gobierno de Perón en 1951, no sólo editorializó en duros términos la elección de Cámpora como presidente, sino

\footnotetext{
${ }^{453}$ Decreto No 35, Bs. As., 29/05/1973, en Boletín Oficial de la República Argentina, No 22705, Año LXXXI, viernes 13 de julio 1973 .

${ }^{454}$ Decreto No 37 , Bs. As., 29/05/1973, en Boletín Oficial de la República Argentina, № 22.684, Año LXXXI, lunes 11 de junio 1973. Luego de la intervención, en la UBA se siguió operando administrativamente según el estatuto vigente, el cual había sido aprobado en 1968 por el decreto 1.529 del presidente de facto Onganía. La futura ley universitaria tenía que comenzar un proceso de normalización de las casas de estudio para culminar en la elección de nuevas autoridades y en la aprobación de nuevos estatutos.

455 “La intervención en la Universidad", en La Nación, 31 de mayo 1973.
} 
que también condenó desde un primer momento la situación de la UNPBA ${ }^{456}$. A días de asumir Puiggrós, publicó un editorial titulado "Universidad intervenida y vilipendiada"457. A su entender, el acto donde el ministro Taiana ungió al interventor parecía "un local político del partido triunfante" en que ambos no habían pronunciado "una sola frase" sobre los "problemas reales" de la enseñanza. Al poco tiempo, el periódico de la familia Paz también manifestó que "el caos en la universidad" había sobrepasado lo imaginable y que el "extremismo ideológico" de "signo internacional" que irradiaba Puiggrós se había apoderado de los claustros ${ }^{458}$. En esta misma línea se pronunció otro importante diario tradicional de la Argentina, La Nación, afirmando que las declaraciones de los nuevos funcionarios traslucían "una voluntad irracional de destrucción" y que la "inesperada entrega" de las universidades sólo había "provocado caos" y era un grave error que el gobierno debía enmendar de inmediato $^{459}$.

Más allá del entusiasmo de unos y la condena de otros, tomamos como punto de partida estos relatos de época para preguntarnos cómo se posicionaron los grupos estudiantiles, docentes e intelectuales que se identificaron con el peronismo de izquierda en el contexto político-académico que abrió la elección de Cámpora como presidente y de Puiggrós como interventor de la UNPBA: ¿Lograron incrementar sus adhesiones en la universidad en el marco de un gobierno peronista que generaba grandes expectativas de cambio? ¿Cómo fue su injerencia en la gestión de Puiggrós? ¿Qué influencia tuvieron en la elaboración de la ley universitaria que anunciaron Cámpora y el ministro Taiana cuando designaron a los interventores y recalcaron la necesidad de crear una normativa consensuada por el conjunto de la comunidad académica? ¿Entablaron nuevos debates con otros sectores del peronismo, la izquierda y el radicalismo en este marco?

\section{II - LA GESTIÓN DE PUiggróS Y EL RESPALdo DEL ACTIVISMo UNIVERSITARIO}

Puiggrós inició su gestión con una condición planteada de antemano en su mismo nombramiento. Debía ser el interventor de la UNPBA hasta la sanción de la nueva ley

\footnotetext{
${ }^{456}$ El diario La Prensa fue fundado en 1869 por José C. Paz y se convirtió rápidamente en una voz del pensamiento liberal-conservador. En 1951 un conflicto gremial, que devino en político, culminó en la expropiación del medio mediante la ley 14.021, la cual fue respaldada en el debate parlamentario con la intervención del entonces diputado John William Cooke. Para un análisis de los posicionamientos políticos de $\mathrm{La}$ Prensa en el contexto del retorno de Perón en 1972 y la asunción del nuevo gobierno peronista al año siguiente, véase: Panella, C., "El regreso de una pesadilla: Perón y el tercer gobierno peronista en la visión del diario La Prensa”, en Rein, R., y Panella, C. (comps.), El retorno de Perón y el peronismo en la visión de la prensa nacional y extranjera, La Plata, EDULP, 2009.

457 "Universidad intervenida y vilipendiada", en La Prensa, 4 de junio 1973.

458 "Marchas y contramarchas en la enseñanza superior", en La Prensa, 14 de junio 1973.

459 “La increíble situación universitaria”, en La Nación, 10 de junio 1973.
} 
universitaria. En consecuencia, tenía dos objetivos inmediatos en su tarea en el rectorado: dar los primeros pasos en la "reconstrucción" de la casa de estudio y generar las condiciones para que sea debatida la ley universitaria. Para impulsar ambas cuestiones, si bien tuvieron un rol destacado sus colaboradores más cercanos en el rectorado y los delegados interventores, quien jugó un papel clave fue la JUP en tanto se constituyó en el principal respaldo de Puiggrós junto a una parte de la militancia estudiantil no peronista.

La importancia de la organización que encabezó José Pablo Ventura se manifestó inmediatamente. A tan sólo unos días de asumir, Puiggrós anunció una serie de medidas que desataron resistencias y oposiciones a su gestión. La primera fue la amnistía para todos los estudiantes que habían sido sancionados por razones políticas o gremiales en años anteriores $^{460}$. La misma estaba en consonancia con la liberación y el indulto a los presos políticos que siguió a la asunción de Cámpora, aunque en el caso de la universidad adquiría un efecto simbólico especial al reconocer y resaltar la militancia estudiantil. La segunda disposición del interventor anulaba las renuncias y cesantías docentes producidas entre 1955 y $1973^{461}$. El período considerado buscaba congregar el apoyo de un amplio abanico de universitarios, dado que la medida incluía a sectores que habían sido apartados de la UBA tras el derrocamiento del primer peronismo, como a los que sufrieron ese mismo destino en 1966. Un caso del primer grupo fue el del historiador nacionalista José María Rosa, mientras el ya peronizado Rolando García del segundo ${ }^{462}$. De todas maneras, la intervención universitaria de 1973 también estuvo acompañada de nuevas renuncias, cesantías y expulsiones. La gestión de la UNPBA justificaba las exoneraciones haciendo alusión a que los profesores apartados habían respaldado al gobierno militar o pertenecían a grandes empresas privadas o multinacionales ${ }^{463}$.

Inmediatamente a esas dos resoluciones que sancionó Puiggrós el 8 de junio, se desató una protesta de un grupo de docentes que reivindicaba al ex rector Bernabé Quartino y al ex decano de Ciencias Exactas Raúl Zardini ${ }^{464}$. Este sector acusaba al nuevo interventor de

\footnotetext{
${ }^{460}$ Res. (C.S.) N ${ }^{\circ}$ 12, UBA, 8 de junio 1973.

${ }^{461}$ Res. (C.S.) N $\mathrm{N}^{\circ} 18, \mathrm{UBA}, 8$ de junio 1973.

${ }^{462}$ Varios docentes y no docentes cesanteados y renunciantes entre 1955 y 1973 fueron reincorporados. Véase: "La reincorporación de los sancionados aumenta la base de apoyo de Puiggrós", en La Opinión, 12 de junio 1973. Además pueden consultarse las siguientes resoluciones del rectorado: Res. (C.S.) $\mathrm{N}^{\circ} 18$, UBA, 8 de junio 1973; No 87, UBA, 18 de julio 1973; No 132, UBA, 26 de julio 1973, entre otras.

${ }^{463}$ En el mes de julio, el rectorado directamente dispuso la incompatibilidad de tareas docentes con el desempeño de funciones jerárquicas o de asesoramiento en empresas extranjeras o multinacionales. Res. (C.S.) $\mathrm{N}^{\circ}$ 89, UBA, 17 de julio 1973.

${ }^{464}$ Quartino fue un geólogo que se desempeñó como interventor en la Facultad de Ciencias Exactas entre 1966 y 1967. Con la asunción de Lanusse, ocupó el rectorado de 1971 a 1973. Un tiempo antes de la llegada de Cámpora al gobierno, fue reemplazado por Carlos Durrieu. Zardini, por su parte, fue geólogo e interventor en Ciencias Exactas entre 1969 y 1973. Véase: www.uba.ar/institucional.
} 
permitir la "infiltración de marxistas y trotskistas" dentro de la casa de estudio porteña ${ }^{465}$. Sus denuncias tuvieron eco en La Nación y La Prensa, dos diarios de tirada nacional que dedicaron una larga serie de notas críticas a la situación universitaria abierta tras la asunción de Cámpora ${ }^{466}$. El principal foco opositor se desarrolló en Exactas y, sobre todo, en la Facultad de Derecho. La designación de Mario Kestelboim como delegado interventor produjo la renuncia de docentes que habían ocupado importantes cargos políticos y judiciales tras el derrocamiento del primer peronismo. Entre los que dimitieron estaban Roberto Alemann, ex ministro de economía de Arturo Frondizi, y juristas como Marco Aurelio Risolía, Luis Carlos Cabral, Jaime Smart y Gabino Salas. Los dos primeros habían sido integrantes de la Corte Suprema de Justicia durante la dictadura saliente, mientras los segundos habían formado parte de la Cámara Federal en lo Penal en ese mismo período. Esta última era recordada como la "Cámara del Terror" o "El Camarón" por haber sido un fuero especial encargado de enjuiciar la actividad "subversiva" de las organizaciones políticomilitares ${ }^{467}$. La distancia de estos sectores con Kestelboim y su equipo no podía ser más amplia. Como explicamos en el tercer capítulo, la mayoría de quienes acompañaban al decano provenía de la Asociación Gremial de Abogados y de la Agrupación de Abogados Peronistas, dos entidades que nucleaban a defensores de presos políticos fuertemente politizados. Es necesario aclarar que las dimisiones no sólo se habían producido como rechazo a la llegada de Kestelboim, sino también porque la JUP había irrumpido en las aulas exigiendo la renuncia de numerosos docentes a principios de junio.

Frente a las primeras manifestaciones de oposición a Puiggrós y los pedidos de desplazamiento del decano de Derecho, la organización de Ventura impulsó el 11 de junio una asamblea en esa casa de estudio y una movilización ante el Ministerio de Educación ${ }^{468}$. A esto

\footnotetext{
465 "Primer intento opositor en la universidad local", en La Opinión, 12 de junio 1973.

466 Frente a los cuestionamientos de los diarios tradicionales, la revista Militancia Peronista para la Liberación dedicó numerosas notas a favor de la gestión de Puiggrós, a la vez que denunciaba a La Nación y La Prensa por intentar crear una imagen de "caos" sobre la universidad. Esta publicación fue dirigida por Rodolfo Ortega Peña y Eduardo Duhalde entre mediados de 1973 y 1974. Tuvo un total de 38 números hasta que fue clausurada en junio de 1974. A partir de ese momento, la revista cambió de nombre y pasó a llamarse De Frente. Véase: "La Prensa y La Nación frente a la Universidad", en Militancia Peronista para la Liberación, № 3, 27 de junio 1973.

467 Junto al lanzamiento del GAN, el régimen de Lanusse había reforzado mecanismos represivos ilegales e instrumentado nuevas disposiciones para lograr mayor efectividad en la represión legal. Dos ejemplos de esta cuestión fueron: por un lado, la sanción de la ley 19.081, la cual autorizaba la intervención de las Fuerzas Armadas para "combatir la subversión"; por otro lado, la ley 19.110, que reglamentaba el funcionamiento de la Cámara Federal en lo Penal para el juzgamiento de la actividad "subversiva". Un panorama general de la gestión de Kestelboim en Derecho, puede consultarse en: Chama, M. y González Canosa, M., "Universidad, política y movimiento estudiantil: la Intervención de Kestelboim y el rol de la Juventud Universitaria Peronista en la Facultad de Derecho de la UBA”, en Conflicto Social, No 5, 2011; Perel, P., Raíces, E., y Perel, M., Universidad y dictadura. Derecho, entre la liberación y el orden (1973-1983), Bs. As., Ediciones del CCC, 2007.

468 "La gestión del rector Puiggrós suscita una ofensiva continuista", en La Opinión, 13 de junio 1973.
} 
se sumó que al día siguiente, el interventor de la UNPBA brindó una conferencia de prensa durante la cual afirmó que existían "maniobras" orientadas a desacreditar a sus funcionarios y a mostrar una imagen de "caos" en la universidad. A la vez defendió a Kestelboim frente a lo que consideraba un "grupito minúsculo desplazado" que creaba dificultades y volvió a destacar el activismo estudiantil. Además, anunció la restitución del título doctor honoris causa que le habían anulado a Perón en 1955 y comunicó que estaba trabajando con todas las facultades en un nuevo sistema de ingreso sin ningún tipo de limitaciones, cupos ni aranceles $^{469}$. Este último punto no sólo debe ser entendido como expresión de una política de gratuidad y libre acceso a la universidad, sino también como un reconocimiento al movimiento estudiantil, dado que una de sus principales demandas había sido justamente el ingreso irrestricto ${ }^{470}$.

En esa misma conferencia de prensa del 12 de junio, Puiggrós informó la creación de una comisión destinada a generar aportes para la redacción de la ley universitaria que el gobierno impulsaría en el corto plazo. Como indicamos previamente, el nuevo interventor de la UNPBA debía encauzar los primeros pasos de la institución, pero también generar debates y propuestas en relación a la futura normativa. Con ese objetivo, el 15 de junio constituyó una comisión integrada por Kestelboim, Miguel Virasoro, Mario Testa y Justino O’Farrell, los decanos de Derecho, Ciencias Exactas, Medicina y de Filosofía y Letras, respectivamente. La misma estaba bajo la coordinación de la Secretaría de Planeamiento del rectorado, a cargo del ex Cátedras Nacionales (CN) Jorge Carpio ${ }^{471}$. A instancias de la comisión y de esta área de la UNPBA se propusieron dos iniciativas. Una fue el lanzamiento de una serie de publicaciones titulada Aportes para la Nueva Universidad, con la intensión de recopilar materiales y propuestas. En su edición no sólo tuvieron en cuenta experiencias históricas como la Universidad Obrera Nacional, discursos de Perón y Cámpora, sino también proyectos de ley

\footnotetext{
469 “Apoyo de estudiantes y docentes jóvenes ratifica su línea de gobierno”, en La Opinión, 13 de junio 1973. La restitución del título doctor honoris causa a Perón se tramitó con la Res. (C.S.) No 17, UBA, 14 de junio 1973. También se impulsaron otras medidas similares como la designación de profesores eméritos, entre los cuales estaban José María Rosa, Hernán Benítez, Leonardo Castellani, Juan José Hernández Arregui, entre otros. Res. (C.S.) No 92, UBA, 17 de julio 1973.

${ }^{470}$ En agosto de 1973 se resolvió crear, para implementar al año siguiente, un curso introductorio único, no limitativo, válido para todas las facultades con un requisito de asistencia al 75 por ciento de las clases. Se diferenciaba de los cursos implementados en años anteriores que culminaban con un examen y una selección por orden de mérito según la cantidad de vacantes. Sin embargo, este curso finalmente fue suspendido y el ingreso irrestricto se encauzó directamente en cada facultad. Para un análisis en profundidad de las políticas que intentó instrumentar Puiggrós en su corta gestión, puede consultarse: Friedemann, S., La Universidad Nacional y Popular de Buenos Aires (1973-1974). Una reforma universitaria inconclusa, FSOC, UBA, Tesis de Doctorado, 2015.

${ }^{471}$ La comisión fue creada mediante la Res. (C.S.) No 29, UBA, 15 de junio 1973. También véase: "Puiggrós crea una nueva comisión", en La Opinión, 27 de junio 1973; Entrevista a Jorge Carpio, C.A.B.A., 30/10/2015 y $20 / 11 / 2015$
} 
universitaria de la Unión Cívica Radical, la Alianza Popular Revolucionaria y de otras casas de estudio nacionales e incluso privadas, como la Universidad Católica y del Salvador ${ }^{472}$. La difusión de documentos de otras fuerzas políticas era acorde al discurso sostenido por Puiggrós respecto a la legitimidad del activismo estudiantil y a su amplia convocatoria de peronistas y reformistas.

La otra iniciativa de la comisión de decanos, que funcionó bajo la dirección de la Secretaría de Planeamiento, fue la elaboración de un documento de discusión titulado "Lineamientos generales para la elaboración de la ley universitaria". El escrito recuperaba los tres ejes centrales del proyecto de universidad de la JUP y ADUP publicados en Envido poco tiempo atrás ${ }^{473}$. Un primer eje buscaba articular el papel orientador del Estado en la educación superior con la participación de los estamentos universitarios y de la comunidad. Para esto, el documento de la comisión de decanos consideraba que el gobierno de la universidad debía estar compuesto por: a)- un rector elegido por el poder ejecutivo; b)- representantes de docentes, estudiantes y no docentes, seleccionados por el voto obligatorio y directo de sus respectivos claustros, en elecciones donde pudieran participar listas propiciadas por fuerzas políticas; y c)- un "cuarto estamento" conformado por referentes vinculados a asociaciones vecinales, gremiales u otras formas de organización comunitaria. El segundo eje proponía que la formación universitaria conjugara trabajo, investigación y enseñanza. En este punto, era central superar la actividad exclusivamente intelectual mediante la participación de estudiantes y docentes en ámbitos productivos, administrativos o culturales. A esto se sumaba la incompatibilidad entre el ejercicio de la docencia y el desempeño de funciones en empresas extranjeras o multinacionales. El último eje establecía la necesidad de garantizar al conjunto de la población el acceso gratuito e irrestricto a la educación superior. El Estado debía asegurar todos los medios para ese fin y la universidad generar cursos de orientación vocacional para priorizar la inscripción en profesiones acordes a las necesidades del país ${ }^{474}$.

Los "Lineamientos generales para la elaboración de la ley universitaria" -redactados por la comisión de decanos que seleccionó Puiggrós- fueron presentados como un primer borrador para que se discutiera entre docentes y estudiantes de distintas facultades. En este

\footnotetext{
${ }^{472}$ Aportes para la Nueva Universidad, Secretaría de Planeamiento, UNPBA, № 1, julio 1973; No 2, julio 1973; $\mathrm{N}^{\mathrm{o}} 3$, agosto 1973; No 4, septiembre 1973; No 5, enero 1974; No 6-7, mayo-junio 1974.

${ }^{473}$ ADUP, "Documento presentado por la Juventud Peronista al compañero Cámpora. Política universitaria", en Envido, N 8, marzo 1973; JUP, “Juventud Universitaria Peronista”, en Envido, № 9, mayo 1973. Véase el cuarto capítulo de la presente tesis.

${ }^{474}$ Los "Lineamientos generales para la elaboración de la ley universitaria" que realizó la comisión de decanos creada por Puiggrós fueron publicado en agosto de 1973 en el tercer número de Aportes para la Nueva Universidad. Se puede consultar: Comisión de delegados interventores, "Lineamientos generales para la elaboración de la ley universitaria. Primer borrador. Esquema para discusión en las bases", en Aportes para la Nueva Universidad, Secretaría de Planeamiento, UNPBA, No 3, agosto 1973, pp. 23-30.
} 
punto la JUP volvió a tener un papel clave porque, desde su propia constitución en el mes de abril, impulsó las “Mesas Universitarias para la Reconstrucción Nacional”. Mediante esa consigna la agrupación liderada por Ventura realizó una serie de actividades a las cuales invitaba a docentes y funcionarios para discutir la política universitaria general y los planes de estudio de las carreras. Las fuertes críticas que recibía la UNPBA en medios como La Nación y La Prensa, en gran parte eran producto de esa estrecha cercanía entre las autoridades de las facultades y la militancia estudiantil. La notable identificación política entre los dos polos de la vida universitaria fue una característica distintiva de toda esta experiencia. A ello se sumó el impulso iconoclasta desplegado en muchas casas de estudio, donde asumieron primeros puestos de gestión jóvenes docentes que no contaban con una extensa trayectoria políticoacadémica $^{475}$. De esta manera, el rectorado de Puiggrós dio sus primeros pasos en medio de conflictos y promesas de cambio, con un estudiantado peronista que se sentía parte y garante de la intervención.

\section{LA INTERNA PERONISTA EN LA UNPBA}

A los primeros altercados desatados en junio por las disputas entre los universitarios opositores y afines a Puiggrós, se sumó otro factor conflictivo que con el tiempo empezaría a tener cada vez más repercusiones en la UNPBA: la interna del movimiento peronista. Tras la "masacre de Ezeiza", el avance de los sectores sindicales y de derecha precipitó la renuncia de Cámpora el 13 de julio de $1973^{476}$. La asunción de Raúl Lastiri, presidente de la Cámara de Diputados y yerno del ministro de Bienestar Social López Rega, como primer mandatario provisional puso en alerta a toda la Tendencia y generó una sensación de incertidumbre respecto a sus áreas de influencia en las reparticiones estatales ${ }^{477}$. En el caso de la universidad

\footnotetext{
${ }^{475}$ Una nota de La Opinión hace una comparación estereotipada entre los perfiles de los interventores de la gestión Puiggrós y de los sectores docentes que cuestionaban y pedían su desplazamiento. Los primeros se caracterizaban por: a)- Jóvenes, militantes políticos y opositores a la última dictadura militar; b)- Receptores del aval político de la mayoría del alumnado peronista y no peronista; c)- Reivindicación de un programa de liberación y posturas radicalizadas. En cambio, los principales rasgos de los segundos eran: a)- Titulares de extensa carrera universitaria comprometidos con la dictadura saliente; b)- Respaldo político de sectores extrauniversitarios enfrentados al gobierno de Cámpora; c)- Opositores a la intervención de Puiggrós a la que consideraban "izquierdista". "Disputas ideológicas en la Universidad”, en La Opinión, 19 de junio 1973.

${ }^{476}$ Acordamos con Marina Franco que el conflicto interno del peronismo ya era perceptible desde la asunción de Cámpora, pero con el episodio de Ezeiza pasó a ocupar el espacio público y nacional. Franco, M., Un enemigo para la nación. Orden interno, violencia y “subversión” 1973-1976, Bs. As., FCE, 2012, p.50. A esto hay que agregar que la Tendencia sufrió desplazamientos antes de los hechos de Ezeiza, como la destitución de Rodolfo Galimberti en el cargo de representante de la JP en el Consejo Superior del MNJ. Jorge Bernetti, un protagonista de la época, llegó a caracterizar a ese suceso como "el inicio de la derrota dentro de la victoria", debido que a los pocos días del triunfo electoral empezaron a manifestarse los primeros trazos de una etapa de lucha interna. Bernetti, J., El peronismo de la victoria, Bs. As., Colihue, 2011, p. 81.

${ }^{477}$ Lastiri estaba casado con la hija de López Rega y había llegado a la presidencia de la Cámara de Diputados a instancias de él. Cuando Cámpora y Solano Lima renunciaron, debía asumir interinamente el vicepresidente de la
} 
porteña, la JUP incluso tomó facultades un día antes de la dimisión de Cámpora, denunciado "un golpe orquestado por la CIA" desde el Ministerio de Bienestar Social con apoyo de la "burocracia sindical" " continuidad de Puiggrós. Frente a estos acontecimientos, la JUP convocó a un acto en la Facultad de Ciencias Económicas en respaldo al interventor y a la candidatura de Perón como presidente. El hecho puso de manifiesto el amplio arco de adhesiones que había conseguido la gestión de la UNPBA, dado que aquella noche del 17 de julio también movilizaron el MOR, el FAUDI y Franja Morada. Durante la concentración, Ventura declaró que existían sectores dentro del movimiento peronista que pretendían "quebrar su carácter revolucionario" y exigía al gobierno provisional de Lastiri “no innovar” en la política iniciada por Cámpora y acompañada por Puiggrós. Al día siguiente, seguía sin confirmarse la continuidad del interventor en su cargo, hasta que declaró públicamente que Taiana le "ratificó su confianza",479.

Luego de estos sucesos, se organizó el 7 de septiembre el Primer Congreso Nacional de la Juventud Universitaria Peronista en la Facultad de Derecho. Durante el encuentro, realizado en el "Día del Montonero", fue conformada la "Mesa de Mando de la Conducción Nacional" de la JUP, la cual pasó a estar integrada por el referente porteño Ventura y los líderes del resto de la regionales del país ${ }^{480}$. Al mitín concurrieron desde militantes del Movimiento de Sacerdotes para el Tercer Mundo hasta delegados de la Juventud Radical y la Federación Juvenil Comunista. En el cierre, Ventura declaró que la militancia había roto "el aparato" que los "enemigos" intentaban poner entre Perón y su pueblo. Por esta razón, consideraba que su candidatura en las inminentes elecciones presidenciales era un "acontecimiento histórico trascendente" en el camino hacia el socialismo nacional ${ }^{481}$.

A pesar de las declaraciones entusiastas de la JUP, el abrumador triunfo electoral de Perón en los comicios del 23 de septiembre y el asesinato de José Ignacio Rucci tan sólo dos

Cámara de Senadores, Alejandro Díaz Bialet. Sin embargo, lo enviaron al exterior en una misión diplomática y debió pedir licencia. En la línea sucesoria le seguía el mismo Lastiri. De Riz, L., Retorno y derrumbe. El último gobierno peronista, Bs. As., Hyspamérica, p. 92.

478 "Los estudiantes peronistas ocuparon ayer todas las facultades de la UBA", en La Opinión, 13 de julio 1973.

479 "El respaldo del estudiantado", en Siete Días, 20 de julio 1973; "Universidad. Fin de la dependencia", en Militancia Peronista para la Liberación, № 7, 26 de julio 1973.

${ }^{480}$ El "Día del Montonero" era rememorado los 7 de septiembre por los asesinatos de Fernando Abal Medina y Carlos Gustavo Ramus en 1970, dos de los fundadores de la organización. El resto de la "Mesa de Mando de la Conducción Nacional" de la JUP estaba integrada por Ramón Puch (Regional II); Alfredo Martelloto (Regional III), Juan Carlos Benítez (Regional IV), Ramón Ponce (Regional V); Carlos Sanhueza (Regional VI) y Jorge Aluano (Regional VIl). La JUP tenía la misma organización en regionales que el resto de los grupos de superficie que respondían a Montoneros. Cada regional hacía referencia a la siguiente división territorial: I Buenos Aires, II Litoral, III Córdoba, IV Noroeste, V Noreste, VI Cuyo, VII Sur. Perdía, R., Montoneros. El peronismo combatiente en primera persona, Bs. As., Planeta, 2013, p. 183.

481 "Primer Congreso Nacional de la Juventud Universitaria Peronista", en El Descamisado, No 17, 1 de septiembre 1973. 
días después, volvió a recrudecer la interna peronista. Ésta tuvo sus propias manifestaciones al interior de la UNPBA. En la jornada siguiente al atentando contra el secretario general de la CGT, El Descamisado, el órgano de prensa oficial de la JP Regionales y Montoneros, anunció que se cernía una "inminente amenaza" contra la universidad ${ }^{482}$. El 28 de ese mismo mes, Ventura, Ernesto López y Cristián Caretti brindaron en la Facultad de Farmacia y Bioquímica una conferencia de prensa en representación de la JUP, la ADUP y la UES, respectivamente. En ella leyeron un documento donde se consideraba que el asesinato de Rucci agudizaba la "ofensiva de sectores reaccionarios e infiltrados en el movimiento" y que éstos buscaban "impedir" la "reconstrucción universitaria". A su entender, eso había quedado de manifiesto con la irrupción en las casas de estudio de grupos armados como la CNU y la Alianza Libertadora Nacionalista, pero sobre todo con el asesinato de Enrique Grynberg, un militante de la JP Regionales que era director del Centro de Investigaciones Aplicadas de la UNPBA ${ }^{483}$.

La tan anunciada ofensiva finalmente llegó el 1 de octubre cuando el ministro Taiana le solicitó la renuncia a Puiggrós por pedido del propio Perón. Al día siguiente, el interventor la presentó y Lastiri, todavía en ejercicio como presidente provisional, dictó el decreto 1.574 para designar interinamente en su puesto al decano de odontología Alberto Banfi ${ }^{484}$. Ese mismo día a su vez fue publicado en La Opinión el "Documento Reservado" del Consejo Superior del Movimiento Nacional Justicialista (MNJ). Este escrito intrapartidario consideraba que el asesinato de Rucci había sido un punto de inflexión y en consecuencia llamaba a librar una "guerra" contra los "grupos marxistas subversivos infiltrados" en el peronismo. Para eso, juzgaba necesario acatar sin vacilaciones las directivas de Perón, utilizar todos los medios disponibles e incluso los resortes del Estado para "reprimir con vigor". Para el diario de Jacobo Timerman, dicho documento había sido anunciado por el mismo Perón en una reunión con gobernadores convocada por Lastiri. Además, según La Opinión, el pedido de renuncia a Puiggrós constituía "el punto más alto" del proceso de “depuración” ideológica del justicialismo ${ }^{485}$.

Frente a estas noticias y la dimisión del interventor de la UNPBA, no se quedaron impasibles ni el activismo universitario ni el propio Puiggrós y sus funcionarios. Desde el

\footnotetext{
482 "La consigna del imperialismo. Liquidar la Universidad antes del 12 de octubre", en El Descamisado, № 19, 26 de septiembre 1973.

${ }^{483}$ Grynberg fue asesinado al día siguiente del atentado contra Rucci. Mientras los demás frentes de masas de la JP Regionales daban declaraciones públicas similares a la JUP, los militantes se iban enterando sorpresivamente que los propios Montoneros habían asesinado al dirigente de la CGT. "La JUP denuncia una ofensiva reaccionaria que intenta frenar la Liberación Nacional", en El Descamisado, № 20, 2 de octubre 1973.

${ }^{484}$ Decreto $\mathrm{N}^{\mathrm{o}}$ 1.574, Bs. As., 02/10/1973, en Boletín Oficial de la República Argentina, No 22.738, Año LXXXI, martes 6 de noviembre 1973.

485 "Drásticas instrucciones a los dirigentes del Movimiento para que excluyan todo atisbo de heterodoxia marxista", en La Opinión, 2 de octubre 1973.
} 
momento en que se conoció el pedido de Taiana el 1 de octubre, todos los decanos interventores hicieron una conferencia de prensa y dirigieron una carta a Perón donde se presentaban como "soldados disciplinados del movimiento", pidiéndole que confirme a Puiggrós en su cargo ${ }^{486}$. Con la misma demanda, ese día a la noche la JUP convocó a una concentración en la Facultad de Ciencias Económicas y a una movilización al Ministerio de Educación. Estas manifestaciones fueron masivas y contaron con la participación de las dos FUA, la FUBA e incluso de sectores estudiantiles críticos de la intervención como TUPAC y $\mathrm{TERS}^{487}$. Al día siguiente, la JUP ocupó todas las facultades y el rectorado con el resto de la militancia y el apoyo de los decanos ${ }^{488}$.

Ante esta situación, Puiggrós terminó reuniéndose con Perón y Solano Lima el 3 de octubre. Llamativamente en ese encuentro el líder del peronismo le negó que haya sido él quien pidió su renuncia. Luego de la reunión, la JUP y Puiggrós realizaron una serie de declaraciones públicas donde informaron lo acontecido y volvieron a acusar al "lastirismo" y al "lopezreguismo" de intentar frenar la edificación de la UNPBA ${ }^{489}$. A esto se sumó que el 4 de octubre la JUP encabezó nuevamente una nutrida marcha al rectorado donde finalmente lograron que Banfi diera un "paso al costado" 490 . Sin embargo, al día siguiente Puiggrós no volvió a ocupar su cargo, sino que Taiana nombró ad-referéndum del poder ejecutivo al secretario general Ernesto Villanueva como encargado provisorio del rectorado, hasta que Perón fuera investido como presidente el 12 de octubre ${ }^{491}$.

Frente a la designación de un hombre de su propio espacio político, la JUP concluyó las ocupaciones y las medidas de fuerza ${ }^{492}$. Al asumir, Villanueva declaró que iba a continuar con la política de Puiggrós y anunció su designación como Profesor Emérito de la Facultad de Filosofía y Letras ${ }^{493}$. Una vez que Perón fue proclamado primer mandatario de la Nación, el

\footnotetext{
486 “A Puiggrós le fue exigida la renuncia y los delegados de facultades lo apoyan”, en La Opinión, 2 de octubre 1973.

${ }^{487}$ Debe recordarse que la FUA estaba dividida en dos sectores desde noviembre de 1970. La FUA La Plata estaba en manos del MOR, la agrupación estudiantil que respondía al PC; mientras la FUA Córdoba era conducida por radicales de FM y socialistas del MNR. En esta última también participaban vertientes de izquierda como el FAUDI, TERS y TUPAC. El primero era el brazo estudiantil del PCR; TERS era el grupo universitario del colectivo trotskista Política Obrera y TUPAC estaba vinculada a Vanguardia Comunista. "Se acepta la renuncia de Puiggrós", en La Razón, 2 de octubre 1973.

488 "La Juventud Universitaria Peronista tomó el Rectorado y ocupó todas las Facultades", en La Razón, 3 de octubre 1973; "Ocuparon anoche el Rectorado de la Universidad", en La Opinión, 3 de octubre 1973.

489 "Perón no solicitó la renuncia de Puiggrós", en La Opinión, 4 de octubre 1973; "Triunfó la Universidad Peronista", en El Descamisado, N ${ }^{\circ}$ 21, 9 de octubre 1973.

490 "El Problema Universitario", en La Razón, 5 de octubre 1973.

491 "Hay un compás de espera en el Problema Universitario", en La Razón, 6 de octubre 1973.

492 “Triunfó la Universidad Peronista", en El Descamisado, № 21, 9 de octubre 1973.

${ }^{493}$ El nombramiento se produce por Res. (C.S.) N ${ }^{\circ}$ 629, UBA, 9 de octubre 1973. La conferencia de prensa de Villanueva está reproducida en Recalde, A., "La Universidad de Buenos Aires en la década de 1970: análisis del comunicado de prensa en solidaridad con Rodolfo Puiggrós", en Salud Colectiva, No 3, 2012, pp. 315-322.
} 
ex CN y militante de Montoneros continuó a cargo del rectorado pese a no ser ratificado. El 25 de octubre, Taiana propuso en su reemplazo a Rodolfo Agoglia, en ese momento rector interventor de la UNLP, pero recibió otra vez la negativa de la JUP ${ }^{494}$. Luego de este compás de espera, a fines de noviembre un decreto del poder ejecutivo confirmó en el cargo a Villanueva $^{495}$. Con tan sólo 28 años, se convirtió en la primera autoridad más joven en toda la historia de la universidad porteña.

¿Cómo se interpretó entonces la renuncia de Puiggrós y su reemplazo por Villanueva? Los sectores estudiantiles y docentes vinculados a la JUP, ADUP, la JP Regionales y Montoneros lo mostraron como un triunfo en las páginas de El Descamisado, haciendo un esfuerzo por explicar que Perón estaba de su parte y que tanto el mismo líder como Taiana e incluso Banfi habían sido involucrados en una "maniobra" de López Rega ${ }^{496}$. Otros espacios donde también se expresaban voces a favor de la UNPBA, eligieron mostrar un diagnóstico menos triunfalista. Éste era el caso de Ciencia Nueva, una revista que publicaba con regularidad trabajos de docentes y profesionales vinculados al Consejo Tecnológico de Rolando García; algunos de los cuales ocupaban cargos universitarios, como Enrique Martínez en el decanato de Ingeniería e Iván Chambouleyrón en el rectorado de la UTN. En su número del 27 de octubre, Ciencia Nueva difundió una nota titulada "U.B.A." a modo de editorial, donde hacía una defensa de Puiggrós y se lamentaba por su renuncia. De todas maneras, alegaba que su dimisión iba a figurar entre los "hechos insólitos" en la "larga y azarosa" historia de la UBA, porque fue requerida en nombre del presidente electo (Perón) que formalmente no podía pedirla ni aceptarla; admitida por un ministro (Taiana) que decía actuar en cumplimiento de órdenes, pero cuando dichas órdenes fueron desmentidas mantuvo la decisión como algo irreversible; y objetada por un estudiantado de amplio espectro político que apoyaba vigorosamente a Puiggrós, pero que aceptó su relevo con una "moderación sin precedentes", ya que denunció "la maniobra" y la repudió, aunque se abstuvo de atacar sus “orígenes aparentes",497.

\footnotetext{
${ }^{494}$ Se puede consultar: "Agoglia, reemplazante de Puiggrós”, en La Razón, 25 de octubre 1973; "Discute la JUP su apoyo a la gestión de Agoglia", en La Opinión, 26 de octubre 1973; "La JUP rechaza a Agoglia como nuevo interventor", en La Opinión, 27 de octubre 1973; "No reemplaza Agoglia a Puiggrós", en La Razón, 27 de octubre 1973; "La JUP rechaza a Agoglia como nuevo interventor", en La Opinión, 27 de octubre 1973.

495 "Habla el interventor en la universidad. Reportaje exclusivo a Ernesto Villanueva", en Noticias, 28 noviembre 1973; "Designóse interventor universitario", en La Prensa, 28 de noviembre 1973.

${ }^{496}$ La revista El Descamisado realizó una cronología de lo que caracterizó como una "exitosa semana de lucha". Véase: "Triunfó la Universidad Peronista", en El Descamisado, $\mathrm{N}^{\circ}$ 21, 9 de octubre 1973. Sergio Bufano sostiene que este tipo de discursos de la JUP mostraban la difícil y enrevesada decisión de la JP Regionales y Montoneros de eludir el enfrentamiento con Perón y no involucrarlo en las medidas que adoptaba el gobierno, perjudicándolos directa o indirectamente. Bufano, S. y Texidó, L., Perón y La Triple A. Las 20 advertencias a Montoneros, Bs. As., Sudamericana, 2015, pp. 163-164.

497 “U.B.A.", en Ciencia Nueva, No 27, octubre 1973.
} 
Este editorial de Ciencia Nueva mostraba la difícil situación de los integrantes de la izquierda peronista en la universidad, especialmente de la JUP, la principal fuerza de movilización que incluso tenía un poder de veto sobre las políticas que atenían a las casas de estudio. No pudo mantener a Puiggrós, pero logró conservar a un docente de su espacio político al frente del rectorado y paralizar no sólo la designación de Banfi, sino también la de Agoglia. A esto se sumaba otra cuestión producto de la politización particular de la JUP. Como vimos, la organización surgió en el contexto del triunfo de Cámpora para atender las especificidades del estudiantado en el marco de dos referencias políticas: el gobierno peronista, al que pretendía aportarle políticas universitarias, y Montoneros, organización con la que seguiría el camino de la "guerra popular y prolongada" en busca del socialismo nacional. Sus dos referentes ahora entraban en conflicto y eso ponía a la JUP en una difícil encrucijada a la hora de legitimar su política en la UNPBA.

\section{III - LOS CENTROS DE ESTUDIANTES Y LA REFUNDACIÓN DE LA FUBA}

Un interrogante importante que queda pendiente es si el surgimiento de la JUP, ADUP y la intervención de Puiggrós implicaron un verdadero afianzamiento del peronismo en el ámbito universitario. Para responder a esta pregunta, podemos tomar como referencia las elecciones estudiantiles de 1973. En la casa de estudio porteña, éstas comenzaron a fines de julio en la Facultad de Ingeniería, continuaron en noviembre en la UTN y finalizaron a principios de diciembre en Arquitectura y Medicina, unos días después de la confirmación de Villanueva como nuevo interventor ${ }^{498}$. El resultado de todos los escrutinios otorgó el primer puesto a la JUP con el 44 por ciento de los votos, seguida por FM con el 21, el MOR con el 18 y la alianza maoísta de FAUDI-TUPAC con el 8. De esta manera, la agrupación encabezada por Ventura triunfó en 9 de los 13 centros de estudiantes disputados. Como lista "Intermesas" en la regional Bs. As. de la UTN y "Azul y Blanca” en las facultades de Económicas, Derecho, Odontología, Arquitectura, Medicina y Filosofía y Letras. Aunque la octava y novena victoria que completan las siete nombradas, no debe adjudicarse sólo a la JUP debido a que en Veterinaria y Agronomía compartió la plataforma electoral ganadora con FM y el MOR. Por otra parte, estas dos agrupaciones también obtuvieron triunfos por su cuenta. Los "morados", específicamente su línea interna agrupada en la Juventud Radical

\footnotetext{
${ }^{498}$ Tomamos en consideración las elecciones en la sede regional Bs. As. de la UTN porque los distintos diarios la tienen en cuenta para contabilizar los resultados finales en la casa de estudio porteña. Para una delimitación de las fechas de inicio y cierre de los comicios, véase: "Elecciones en Ingeniería", en Bandera Roja, 10 de septiembre 1973; "Compiten peronistas y marxistas", en Noticias, 19 de noviembre 1973; "Bajo sueldos pero lo respaldan", en Noticias, 21 de noviembre 1973; "Finalizan elecciones estudiantiles", en Noticias, 1 de diciembre 1973.
} 
Revolucionaria (JRR), consiguieron el primer puesto en la Facultad de Ingeniería, mientras los comunistas aventajaron a las demás listas en Exactas y Farmacia y Bioquímica ${ }^{499}$.

El cambio del panorama político porteño era notorio si tenemos en cuenta que en las elecciones del año anterior ni siquiera se habían presentado las organizaciones que formaban parte de la JUP y el MOR había obtenido una holgada victoria con el 46,9 por ciento de los votos, dejando en un lejano segundo lugar a FM. Además, la legalización de los comicios estudiantiles a raíz de la apertura democrática estuvo acompañada de un crecimiento vertiginoso en la participación política. En 1973 se cuadriplicó la cifra de votantes gracias a que intervino aproximadamente el 50 por ciento de la población estudiantil metropolitana. En un año se pasó de 13.000 sufragantes a más de 50.000, en un proceso electoral que continuaba siendo no obligatorio. Los resultados mostraron un claro triunfo de la JUP, un estancamiento del MOR y el crecimiento del radicalismo, a pesar de haber obtenido un centro menos que los comunistas. Mientras en 1972 el MOR obtuvo 6.100 votos y FM 1.592, al año siguiente lograron 9.555 y 10.824 sufragios, respectivamente. Así, los comunistas aumentaron su caudal electoral en mucha menor proporción que los radicales en términos comparativos. Mientras que la JUP aventajó ampliamente a ambos sumando un total de 20.719 sufragios en su primera participación electoral ${ }^{500}$.

Sin embargo, estos resultados no sólo manifestaban la transformación del escenario político de la UBA al imponerse la JUP en casi todos los centros que había conquistado el MOR en las elecciones anteriores. Desde una mirada retrospectiva, también puede rastrearse una continuidad importante entre 1972 y 1973. Esa persistencia estaba dada por el afianzamiento de los centros de estudiantes frente a otras formas de participación política. Retomando lo trabajado en capítulos anteriores, podemos afirmar que si 1971 había sido el año de los cuerpos de delegados, 1972 y 1973 volvieron a poner en el centro de la escena a los organismos tradicionales del movimiento estudiantil. Lo paradójico es que en la consolidación

\footnotetext{
${ }^{499}$ Dentro de FM existían dos tendencias: la Juventud Radical Revolucionaria que era más cercana a Ricardo Balbín y la Juventud Radical afín a Ricardo Alfonsín. En las elecciones de Ingeniería de 1973, fue electo presidente del centro de estudiantes Miguel Ponce de la JRR. Entrevista a Miguel Ponce, C.A.B.A., 20/11/2015 y 27/11/2015. Para consultar testimonios, documentos y entrevistas sobre la historia de la Juventud Radical en los setenta, véase: Muiño, O., Los días de la Coordinadora: política, ideas, medios y sociedad (1968-1983), Bs. As., Corregidor, 2011 b y La otra juventud. De la insignificancia al poder: protagonistas y relato de la Junta Coordinadora Nacional de la Juventud Radical (1968-1983), Bs. As., Corregidor, 2011a; Ponce, M., Testimonios. A 25 años del golpe, CABA, FUBA/UBA/Página 12, 2000, pp. 61-65.

${ }^{500}$ Los resultados de 1973 en cada una de las unidades académicas y la comparación entre los comicios de dicho año y el anterior, puede consultarse en: "En Arquitectura y Medicina ganó la JUP", en La Nación, 4 de diciembre 1973; "Sufragaron 54 mil alumnos", en Noticias, 5 de diciembre 1973; "El triunfo de la JUP y el futuro político", en La Nación, 6 de diciembre 1973. Un dato a tener en cuenta es que en los resultados totales por agrupación La Nación otorga a la JUP 23.716 sufragios, mientras Noticias 20.719. La diferencia surge porque el primer periódico suma los votos de los frentes de Veterinaria y Agronomía a la JUP, cuando en realidad habría que considerarlos aparte de los resultados de cada agrupación particular.
} 
de esa tendencia tuvo un papel protagónico la JUP, organización surgida de la unificación de agrupaciones que hasta entonces se habían negado a participar en los comicios e incluso habían privilegiado a los cuerpos de delegados sobre los centros de estudiantes.

Este reposicionamiento del peronismo fue reconocido y celebrado por los propios reformistas. En el nuevo periódico Noticias, dirigido por Miguel Bonasso e integrado por otros periodistas vinculados a la JP Regionales y Montoneros ${ }^{501}$, el radical Enrique Arana consideraba como un avance la participación de la JUP en las elecciones porque a su entender la unidad del estudiantado sólo podría alcanzarse "superando viejos enfrentamientos" dentro de los centros y sus respectivas federaciones. Para el dirigente de FM-JRR, que además era miembro de la junta ejecutiva de FUA-Córdoba, este cambio había sido posible por el apoyo dado por peronistas, comunistas y radicales a la intervención universitaria abierta a principios de año y porque ese mismo respaldo muchas veces se tradujo en acciones políticas en común entre las tres corrientes mencionadas ${ }^{502}$.

Ventura, el titular de la Regional I e integrante de la mesa nacional de la JUP, también abordó la cuestión en el diario Noticias, a raíz de un interrogante que nadie pasaba por alto: “PPor qué decidieron participar en las elecciones si antes se negaban?”. Desde un discurso que volvía pivotear entre la lógica militar y la político-institucional, aducía que esta "readaptación" se debía a una "nueva etapa de la guerra popular" que ya no exigía el enfrentamiento abierto contra la proscripción y la dictadura, sino la creación de "instancias de participación de masas" en el marco del nuevo gobierno, a pesar de todas las "contradicciones" que podían achacársele al mismo. Estos dichos giraban sobre la vieja idea de la "isla democrática" que los peronistas habían utilizado en más de una oportunidad para justificar su ausentismo electoral. Como en años anteriores se le había negado al peronismo la participación en los comicios, optaron por no legitimar los mecanismos político-formales de representación en ningún ámbito particular y por organizarse en espacios alternativos para denunciar a ese "régimen fraudulento". Esos ámbitos podían ir desde un cuerpo de delegados hasta una organización armada. En cambio, en 1973 cuando el peronismo ya había triunfado en las elecciones, se volvía necesario aprovechar todas las instancias de participación, aunque sin abandonar otras formas necesarias de intervención, como la lucha armada. Esas otras formas serían las que permitirían superar "los límites" del gobierno, al que se había llegado

\footnotetext{
${ }^{501}$ Noticias apareció por primera vez el 19 de noviembre de 1973. Era un órgano de prensa vinculado a Montoneros, pero a diferencia de El Descamisado no se presentaba como un medio orgánico, con lo cual poseía un discurso más diverso y menos politizado. Esquivada, G., Noticias de los Montoneros, Bs. As., Sudamericana, 2010.

502 "Los radicales satisfechos. Reportaje a Enrique Arana, dirigente universitario de Franja Morada", en Noticias, 6 de diciembre 1973.
} 
por los mecanismos de la "democracia formal", y conquistar el poder mediante una guerra que aún no había terminado ${ }^{503}$.

Desde esta perspectiva, Ventura argumentaba que el cambio de la abstención a la participación estaba demostrando efectividad, no sólo porque el peronismo había triunfado en la mayoría de centros de estudiantes, sino porque también obtenía importantes resultados en las elecciones docentes, realizadas contemporáneamente en algunas casas de estudio ${ }^{504}$. En este punto, hacía referencia implícitamente a la performance de ADUP, la agrupación que aglutinaba a los profesores que se referenciaron políticamente con la JP Regionales. A fines de noviembre, con una campaña centrada en el apoyo a la intervención de la UNPBA y en el proyecto de ingresar a la Confederación de Trabajadores de la Educación (CTERA) para poder agremiarse junto a docentes primarios y secundarios, sus listas vencieron a la alianza constituida por el PC y el Partido Socialista de los Trabajadores en la Facultad de Ciencias Exactas, a la plataforma "Marrón" del PCR en Arquitectura y a otra vinculada al comunismo en Filosofía y Letras ${ }^{505}$.

Antes de continuar con las razones que daban los propios protagonistas a sus cambios de posicionamiento político, queda pendiente el interrogante sobre si el peronismo se había afianzado en el ambiente universitario. Este punto parece incuestionable, no sólo porque logró encabezar la gestión de la UNPBA y obtuvo importantes triunfos en los comicios docentes, sino, y sobre todo, porque consiguió un amplio respaldo en la población estudiantil. Este era, sin duda, el hecho más relevante de esta experiencia. Muchos trabajos han sostenido que para rastrear la peronización universitaria es necesario poner el foco en el golpe de 1966 o en el Cordobazo $^{506}$ ¿Pero puede hablarse verdaderamente de peronización en el período que antecede a los setenta? Si entendemos a la peronización como la capacidad de lograr una adhesión masiva de la comunidad académica, este proceso adquiere realidad y un auge sin precedentes en la UBA recién en 1973. Ese año terminó de configurarse todo un sector del peronismo que logró articular detrás de sí un respaldo importante del estudiantado e incluso el apoyo de las organizaciones más relevantes del radicalismo y la izquierda.

\footnotetext{
503 "Los estudiantes votaron con el país. Declaraciones exclusivas de Pablo Ventura, de la regional uno de la Juventud Universitaria Peronista”, en Noticias, 5 de diciembre 1973.

${ }^{504}$ Ibídem.

505 “Terminó elección docente”, en Noticias, 2 de diciembre 1973.

${ }^{506}$ Por sólo nombrar algunos estudios de varios que señalamos en la parte introductoria de la tesis: Barletta, A. M., "Peronización de los universitarios (1966-1973). Elementos para rastrear la constitución de una política universitaria peronista", en Pensamiento Universitario, año 9, № 9, Bs. As., abril 2001; Reta, M. A., El proceso de peronización dentro del movimiento universitario en los años sesenta en la Argentina. El caso del Frente Estudiantil Nacional, Tesis de Maestría, FSOC, UBA, 2010; Recalde, A., Intelectuales, peronismo y universidad, Bs. As., Punto de Encuentro, 2016.
} 
Además, como ya indicamos en otras oportunidades, es importante recalcar que no se trató de cualquier peronización, sino de una orientada a la izquierda. El arco del peronismo que encabezó este proceso fue el que se consolidó al calor del retorno de Perón y la campaña electoral bajo la hegemonía de la JP Regionales y Montoneros. Las elecciones estudiantiles de 1973 vuelven a ser sugestivas en dicho aspecto. El FEN, que a fines de los sesenta era considerado la agrupación más importante de "pasaje al peronismo" y a principios de la década siguiente se diferenció de las organizaciones armadas conformando la Organización Única de Trasvasamiento Generacional (OUTG) junto a Guardia de Hierro, obtuvo un magro resultado electoral con 1.043 votos, debido a que sólo presentó sus listas en las facultades de Ingeniería y Odontología ${ }^{507}$. Su situación era bastante particular. Proveniente de sectores reformistas y de izquierda, en 1973 el FEN terminó abandonado el discurso sobre el socialismo nacional y puso en primer plano su lucha contra "la sinarquía internacional" Desde este enfoque, justificaba su abstención en casi todas las casas de estudio porque acusaba a la JUP de pretender crear una "isla revolucionaria" y una nueva "Unión Democrática" junto a radicales y comunistas ${ }^{509}$.

No obstante, el auge de la peronización de izquierda parece haber sido una excepcionalidad de la UBA y no una regla para el conjunto de las universidades. Como han indicado algunos trabajos, constituye un error analítico generalizar las experiencias de dicha casa de estudio al resto del país ${ }^{510}$. Los sufragios a centros de estudiantes a nivel nacional

\footnotetext{
507 "El triunfo de la JUP y el futuro político", en La Nación, 6 de diciembre 1973.

${ }^{508}$ Humberto Cucchetti señala que la palabra "sinarquía", como expresión de una amenaza internacional contra la nación, si bien no estuvo ausente en expresiones de izquierda, adquirió gran asidero en las alas más duras del nacionalismo. En Argentina, tuvo gran predicamento a partir del intelectual y escritor Carlos Disandro, el referente de la CNU. Durante el tercer gobierno peronista, sectores de la OUGT como el FEN, comenzaron a reivindicar los conceptos de "comunidad organizada", "patria peronista" y "conducción personal". Desde ellos, objetaron a la Tendencia su validez política y nacional al catalogarla como una "deformación marxista" y una "infiltración sinárquica". En este punto, el autor sugiere que poco importaba que esas representaciones estuvieran imbuidas de significados que poco tiempo antes pudieron haber sido asignados a los mismos actores que ahora defendían un "peronismo histórico" y descartaban la idea de "socialismo nacional". Cucchetti, H., Combatientes de Perón, herederos de Cristo, Bs. As., Prometeo, 2010, pp. 187-190.

509 "La posición de FEN-OUP", en Las Bases. Órgano oficial del Movimiento Nacional Justicialista, № 69, 21 de noviembre 1973. En relación a este tema, también es importante tener en cuenta que a diferencia de la JUP, el FEN-OUP y la derechista CNU se habían manifestado contra la continuidad de Puiggrós y en apoyo de Banfi como su reemplazante. A pesar de estas posturas en común, coincidimos con Juan Besoky de que por su trayectoria y posicionamientos políticos generales, los sectores de la OUTG deberían ser ubicados en el centro político, a una distancia más o menos equidistante -dependiendo el momento- de la derecha y la izquierda del peronismo. Besoky, J. L., La derecha peronista. Prácticas políticas y representaciones (1943-1976), Tesis Doctoral, FaHCE, UNLP, 2016, p. 196.

${ }_{510}$ Germán Soprano sugiere que las lecturas sobre la historia de las universidades y sobre el campo intelectual han sido formuladas desde un punto de vista excesivamente "porteñocéntrico". Por esta razón, si son aplicadas mecánicamente pueden obturar la posibilidad de encontrar procesos de mayor ambivalencia que los producidos en la UBA. Soprano, G., "De la pedagogía a la ciencia de la educación. A propósito de un estudio sobre intervenciones políticas y académicas de los pedagogos en el ámbito universitario", en Propuesta Educativa, $\mathrm{N}^{\circ}$ 28, 2006.
} 
evidencian la especificidad del caso porteño. A principios de diciembre de 1973, las elecciones realizadas en casi una centena de unidades académicas contaron con la participación de 122.823 alumnos, una cifra sin precedentes en la Argentina. Del total de votos computados, 99.718 se repartieron entre las cinco principales tendencias: la JUP con 24.550, el MOR con 22.120, FM con 20.402, el FAUDI-TUPAC con 15.035 y el MNR con 10.824. Si comparamos los resultados obtenidos por la agrupación peronista a nivel nacional con los cosechados en la UBA, salta a la vista que la inmensa mayoría de sus votos pertenecían a dicha casa de estudio. Esto se debe, entre otras razones, a que la JUP no se presentó en los sufragios de importantes universidades, como La Plata, Rosario, Córdoba y el Litoral. Los números de participación en elecciones por grupos estudiantiles eran elocuentes. Mientras el FAUDI-TUPAC participó en 63 comicios, el MOR en 61 y FM en 42, la JUP sólo contabilizó una veintena de intervenciones electorales. A los contundentes triunfos porteños, sólo pudo sumar los primeros puestos obtenidos en unidades académicas más pequeñas como Río Cuarto y Lomas de Zamora, además de las victorias parciales en Bahía Blanca en alianza con AUN, en Tucumán y Mar del Plata con la lista Frente Universitario de Liberación (FUL) compartida con el MNR y en Mendoza junto con el MOR y FM ${ }^{511}$.

El panorama político-universitario de los setenta era más complejo de lo que suelen sugerir algunas interpretaciones generales referidas a los procesos de politización, radicalización y peronización. En el tercer capítulo afirmamos a partir de la lectura de Silvia Sigal que la experiencia de la JUP en la UBA puede mostrarse como un caso paradigmático de "partidización" de la comunidad académica, en tanto dicha agrupación se definía principalmente por su pertenencia político-partidaria ${ }^{512}$. Pero este señalamiento no debe opacar otro tipo de cuestiones. La organización liderada por Ventura no consolidó su hegemonía política en 1973 de cualquier manera, sino que lo hizo a través del organismo político-gremial que habían defendido históricamente todas las corrientes que se identificaron con la Reforma de 1918 ¿Por qué la JUP que había surgido de un conjunto de agrupaciones que reivindicaban a los cuerpos de delegados se lanzó de lleno a la conquista de centros de estudiantes? ¿Esto se debía a que los sectores reformistas y peronistas habían superado los viejos enfrentamientos, como afirmaba el radical Arana en Noticias? ¿O era producto de que el fin de la proscripción del peronismo reclamaba nuevas tácticas políticas, como

\footnotetext{
511 "Votaron 123 mil alumnos universitarios", en Noticias, 10 de diciembre 1973.

${ }^{512}$ Sigal, Silvia, Intelectuales y poder en la década del sesenta, Bs. A.s, Puntosur, 1991, p. 71. Más allá de la JUP, fue una característica general de la elección estudiantil de 1973 la definición partidaria de la mayoría de las agrupaciones que participaron. Esto expresaba, entre otras cosas, el creciente protagonismo de las ramas juveniles de los partidos políticos.
} 
argumentaba Ventura en ese mismo periódico? Ambos señalamientos son importantes y tienen algo de razón, pero es necesario tener en cuenta que la JUP construyó un discurso menos anti-reformista de lo que a veces se presenta y más atento a pensar las particularidades de la universidad y el movimiento estudiantil de lo que se cree.

En este sentido, también es relevante considerar la incursión de la JUP en la FUBA. Luego de las elecciones estudiantiles, peronistas, radicales y comunistas acordaron convocar al congreso de la federación universitaria porteña para el 22 de diciembre de 1973. En las reuniones previas a su realización, la JUP propuso modificar el nombre de la entidad como símbolo de los nuevos tiempos. Para eso, planteó dos opciones: "Federación de la Liberación Nacional” o "Federación de la Reconstrucción Nacional”. FM concordaba en que la idea de "liberación" no sectorizaba y mostraba el cambio de los últimos años, pero a su entender había que incluir una referencia al carácter regional de la entidad ${ }^{513}$. De esta manera, el día 22 en el aula magna de la Facultad de Medicina fue constituida la Federación Universitaria para la Liberación Nacional de Buenos Aires (FULNBA). Su presidencia quedó a cargo de Miguel Talento (JUP) y la secretaría general en manos de Rafael Pascual (FM-JRR), ambos estudiantes de Derecho ${ }^{514}$. Los principales puntos acordados en el congreso apuntaban a apoyar la intervención de la UNPBA, atender las particularidades del movimiento estudiantil y encarar próximamente su unificación nacional ${ }^{515}$. Por entonces, seguían existiendo dos FUA, la "Córdoba" encabezada por los radicales y "La Plata" dirigida por los comunistas ${ }^{516}$. Si bien este debate quedó pendiente para más adelante, la JUP planteó un proyecto que era sintomático del nuevo peronismo universitario que terminó de definirse en los setenta: la futura central nacional de estudiantes no podría llamarse "Federación Universitaria Argentina" por las reminiscencias "gorilas" de ese nombre, pero tampoco "Confederación

\footnotetext{
513 "JUP y Franja Morada cambian nombre a FUBA", en Noticias, 6 diciembre 1973; "Congreso de FUBA. Tratativas peronistas-radicales", en Noticias, 7 de diciembre 1973; "FUBA. Mañana inicia su congreso. Acción mancomunada de peronistas y otros sectores", en Noticias, 21 de diciembre 1973.

${ }^{514}$ La Mesa Ejecutiva de la FULNBA quedó conformada por 15 miembros: 7 de la JUP, 5 de FM, 3 del MOR y 1 de la alianza FAUDI-TUPAC. "Se realiza hoy el congreso de la FUBA", en Noticias, 22 de diciembre 1973; Entrevista a Miguel Talento, C.A.B.A., 11/01/2016 y 04/05/2016; Entrevista a Rafael Pascual, C.A.B.A., $17 / 12 / 2015$

515 "A un paso de la unidad estudiantil. La JUP propuso integrar de inmediato una nueva central nacional", en Noticias, 15 de diciembre 1973; "FULNBA: unidad estudiantil concretada", en Noticias, 24 de diciembre 1973.

${ }^{516}$ Entre el 15 y 17 de diciembre se había llevado adelante el XIII Congreso de FUA Córdoba en Rosario. En el mismo, se eligió como presidente a Federico Storani, estudiante de Derecho de la UNLP. La FUA Córdoba estaba basada en una alianza entre FM y el MNR. Al encuentro, concurrió una delegación de la JUP encabezada por Ventura en carácter de observadora. Por otra parte, en 1973 la FUA La Plata estaba presidida por el comunista Jorge Alberto Kreyness. La división de la FUA no era nueva y databa desde fines de 1970. Véase: "Storani presidiría FUA - Córdoba. Trascendió que su designación ya está acordada" y "El MOR no aspira a ser mayoría. Entrevista a Kreyness, presidente de FUA - La Plata", en Noticias, 14 de diciembre 1973.
} 
General Universitaria”, por estar ese sello identificado con una "política nefasta" ${ }^{217}$. De esta manera, la izquierda peronista construía su propia experiencia intentando superar los símbolos del reformismo y el primer peronismo, los cuales evocaban viejos años de desencuentros entre fuerzas que ahora marchaban unidas bajo la bandera de "liberación".

\section{IV - LA IZQUIERDA PERONISTA ANTE LA LEY TAIANA}

Desde el inicio del tercer gobierno peronista se había afirmado que la nueva legislación universitaria debía surgir del aporte y la discusión de diversos sectores, especialmente de la comunidad académica. El propio Cámpora había resaltado esto ante la asamblea legislativa el día de su asunción e incluso figuraba en los considerandos de su decreto de intervención de las universidades nacionales ${ }^{518}$. Sin embargo, el 11 de junio de 1973, el ministro Taiana anunció oficialmente la creación de una comisión especial presidida por él para confeccionar las bases de una nueva normativa. En ella no había ningún representante de la izquierda peronista y entre sus principales integrantes estaban Ricardo Guardo, Horacio Domingorena y Jorge Vanossi. El primero había sido el redactor de la primera ley universitaria del peronismo (13.031), el segundo de la normativa que habilitó a las universidades privadas a otorgar títulos académicos y el tercero el secretario de la UBA en la gestión de Carlos Durrieu, el último rector de la dictadura saliente ${ }^{519}$.

Frente a los primeros rumores de que Taiana pretendía contrarrestar el peso de los actores vinculados a la Tendencia y cerrar la discusión ${ }^{520}$, el mismo ministro brindó una conferencia el 25 de junio ante los interventores de las universidades nacionales y les pidió que elevaran propuestas concretas para ser tenidas en cuenta en la elaboración de la ley. Indicó como fecha límite el 31 de agosto porque pretendía presentar el proyecto al congreso ese mismo año ${ }^{521}$. Por su parte, Puiggrós ya había creado el 15 de junio una comisión de

\footnotetext{
${ }^{517}$ El diario Noticias describía esta posición de la JUP en los siguientes términos: "Luego de un debate entre los miembros de su dirección, la JUP rechazó la idea de proponer como nombre para la futura central nacional, el de Confederación General Universitaria (CGU). El nombre de CGU fue descartado, según se supo, porque si la FUA es símbolo de gorilismo, la CGU está identificada con una política nefasta". Véase: "Apoyo de la FULNBA a los interventores", en Noticias, 26 de diciembre 1973.

518 "Mensaje ante la asamblea legislativa", 25 de mayo 1973, en Cámpora, H., La revolución justicialista, Bs. As., Eudeba, 1973, pp.187-188; Decreto No 35, Bs. As., 29/05/1973, en Boletín Oficial de la República Argentina, $\mathrm{N}^{\circ}$ 22705, Año LXXXI, viernes 13 de julio 1973.

${ }^{519}$ La comisión comenzó a funcionar el 15 de junio. Los restantes miembros eran José Cravero, Julio Fortezza y su secretario Alberto Godoy. "Crean una comisión que redactará ley universitaria", en La Opinión, 12 de junio 1973; "La gestión del rector Puiggrós suscita una ofensiva continuista", en La Opinión, 13 de junio 1973; "Hoy inicia sus tareas la comisión que redactará la futura ley universitaria”, en La Opinión, 15 de junio 1973.

520 "FUA - La Plata define los alcances de su apoyo a las autoridades universitarias", en La Opinión, 16 de junio 1973; "Desfavorable reacción de estudiantes reformistas. Actúa la comisión redactora de una ley", en La Opinión, 22 de junio 1973.

521 "Jorge Taiana delimitó las atribuciones de los interventores de las casas de estudio", en La Opinión, 26 de
} 
decanos con ese fin, bajo la coordinación de la Secretaría de Planeamiento a cargo de Carpio, un sociólogo ex CN referenciado con la JP Regionales. Desde este espacio, se impulsó la publicación Aportes para la Nueva Universidad y se elaboró el documento "Lineamientos generales para la elaboración de la ley universitaria". El mismo fue presentado por Testa, el decano de Medicina, en una conferencia de prensa a principios de agosto y entregado a la comisión del Ministerio de Educación que presidía Taiana ${ }^{522}$. Como señalamos anteriormente, estos lineamientos para discutir la nueva normativa que elaboraron los funcionarios de Puiggrós estaban en sintonía con los primeros proyectos sobre universidad que habían difundido la JUP y ADUP en Envido antes de la asunción de Cámpora.

Hacia fines de 1973, Puiggrós ya no estaba más al frente de la UNPBA y Taiana aún no había elevado ninguna propuesta al parlamento. Sin embargo, paralelamente al congreso donde surgió la FULNBA el 22 de diciembre, empezó a correr la noticia de que Perón y Balbín se habían puesto de acuerdo para sancionar una ley universitaria en las sesiones extraordinarias de verano. A fin de mes, Talento en conferencia de prensa leyó un documento en el cual las distintas fuerzas de la federación porteña llamaban a posponer el tratamiento para después de febrero, debido a que en esa fecha era muy difícil la participación de los universitarios $^{523}$. La preocupación central del presidente de la FULNBA era que durante el receso vacacional decaía la militancia estudiantil y eso les quitaba capacidad de intervenir. Finalmente, Perón y Taiana firmaron el proyecto de ley y lo presentaron al senado el 12 de febrero de $1974^{524}$. Mientras FM, el FAUDI y TUPAC realizaron una movilización al congreso en protesta el día 20; la JUP decidió organizar un encuentro el 22 en la Facultad de Derecho para fijar su posición ante la nueva situación ${ }^{525}$.

junio 1973. Puede consultarse el discurso que brindó el ministro ese día en: Taiana, J., "La universidad no es una isla en el proceso nacional. Exposición del Señor Ministro de Cultura y Educación ante los Señores Interventores de las Universidades Nacionales en la reunión realizada el día 25 de junio", Ministerio de Cultura y Educación, Centro Nacional de Documentación e Información Educativa, Bs. As., julio 1973.

522 "La elaboración de la nueva ley motiva polémicas en las casas de estudios", en La Opinión, 2 de agosto 1973. Como vemos, el pedido de Taiana se cumplió en la UNPBA durante el tiempo acordado. Además, ese mismo mes se publicó el documento de la comisión de decanos en la revista institucional de la universidad. "Lineamientos generales para la elaboración de la ley universitaria", en Aportes para la Nueva Universidad, Secretaría de Planeamiento, UNPBA, No 3, agosto 1973.

523 "La FULNBA no acepta que la ley sea sancionado durante el receso de verano y exige un debate previo", en Noticias, 29 de diciembre 1973.

${ }^{524}$ El 12 de febrero, Taiana presentó en el congreso el proyecto de ley. El discurso que brindó en esa ocasión fue difundido luego por el propio Ministerio de Educación. Se puede consultar en: Taiana, J., "Exposición de S.E. el señor Ministro de Cultura y Educación de la Nación, Dr. Jorge A. Taiana, ante el Honorable Congreso de La Nación presentando el Proyecto de Ley destinado a regir las Universidades Nacionales el 12 de febrero de 1974", en Espíritu y normas de aplicación de la Ley Universitaria, Ministerio de Cultura y Educación, Centro Nacional de Documentación e Información Educativa, Bs. As., 1974.

525 "La Ley Universitaria. Taiana respondió a las críticas del radicalismo", en Noticias, 19 de febrero 1974; "La cuestión de la autonomía es fundamental para la JRR", El Cronista Comercial, 20 de febrero1974; "Ley 
En el acto realizado por la noche en el aula magna de la casa de estudio que encabezaba Kestelboim, Ventura leyó una declaración política en la cual anunciaba el apoyo de la JUP al proyecto de ley del poder ejecutivo, a la vez que solicitaba modificaciones y la continuidad de los actuales interventores una vez sancionado el texto legal e iniciado el período de normalización. El respaldo de la JUP lo justificaba porque la propuesta enviada al congreso reconocía principios que la agrupación había sostenido desde sus inicios ${ }^{526}$. Entre ellos, Ventura resaltaba la definición de las universidades como "comunidades de trabajo", encargadas de formar profesionales e impartir la enseñanza técnico-científica para aportar a la "liberación nacional" y solucionar los problemas regionales del país; además de orientarlas a la promoción de cultura nacional como a la producción de bienes y servicios sociales, con el fin de eliminar la distinción entre trabajo manual e intelectual (Art. $1^{\circ}$ y $\left.2^{\circ}\right)^{527}$. También destacaba que explicite que la universidad no podía aceptar subsidios o préstamos condicionantes de organismos internacionales, junto a la prohibición de ejercer cargos docentes o administrativos en paralelo con funciones en empresas multinacionales (Art. $11^{\circ} \mathrm{y}$ $47^{\circ}$ ). Por otro lado, Ventura consideraba importante que el proyecto contemplara el establecimiento de la gratuidad de la enseñanza universitaria y dos elementos que caracterizaba como de "suma corrección y legitimidad": la presencia del poder ejecutivo en el gobierno de las casas de estudio, a través de su potestad de designar a los rectores, y la participación de los claustros docentes, estudiantiles y no docentes (Art. $23^{\circ}$ y $33^{\circ}$ ); además de garantizar vías para la colaboración de la comunidad extra universitaria (Art. $27^{\circ}$ ).

Efectivamente, estos ejes del proyecto de Taiana compartían los grandes lineamientos de las propuestas iniciales de la JUP, ADUP y del documento de la comisión de decanos que había creado Puiggrós en la Secretaría de Planeamiento de la UNPBA. No obstante, la inminente sanción de la ley y el contexto político hizo precisar a la JUP algunas de sus ideas en relación con estos temas. Así lo manifestó el mismo Ventura en su lectura de las modificaciones que solicitaron para la normativa. La primera se refería a que en los órganos de gobierno, los claustros de docentes, estudiantes y no docentes tuvieran la misma cantidad de representantes, no una distribución del 60,30 y 10 por ciento como establecía el proyecto del ejecutivo $\left(A r t .30^{\circ}\right)$. La segunda pretendía eliminar la cláusula que avalaba la remoción de

universitaria: piden postergarla", en Noticias, 21 de febrero 1974; "Manifestación estudiantil en el Congreso", en La Nación, 21 de febrero 1974.

526 "La Universidad. La JUP apoya la ley", en Noticias, 24 de febrero 1974; "Posición de la JUP ante la ley universitaria", en La Nación, 24 de febrero 1974.

${ }^{527}$ Para todas las referencias al proyecto de ley original enviado por Perón y Taiana al congreso, véase: "Régimen de universidades nacionales - Mensaje y proyecto de ley del Poder Ejecutivo", en Cámara de Senadores de la Nación, $65^{\mathrm{a}}$ reunión, continuación de la $15^{\mathrm{a}}$ Sesión Extraordinaria, 4 y 5 de marzo 1974, pp. 3605-3632. 
docentes por "proselitismo partidario" o "ideas contrarias al sistema democrático" (Art.12), debido a que este tipo de disposiciones podrían dar lugar a la proscripción política en la universidad. En relación a este punto, también se consideraba necesario precisar la idea de "alteración del orden público" como causante de intervención de las casas de estudio, además de asentar que ésta no pudiera ser realizada por el poder ejecutivo, sino por el congreso (Art. $50^{\circ}$ ). Finalmente, la última modificación propuesta era no contemplar el artículo que facilitaba la posibilidad de exigir estudios complementarios o cursos de capacitación antes de aceptar a alumnos a determinadas facultades, departamentos o carreras, porque eso podría dificultar el ingreso irrestricto (Art. $\left.35^{\circ}\right)^{528}$.

El 29 de enero las agrupaciones universitarias habían concurrido al congreso a exponer sus puntos de vista. Había asistido Ventura en representación de la JUP, Talento por la FULNBA y Ricardo Sidicaro, otro ex CN que era secretario académico de la Facultad de Filosofía y Letras, por ADUP ${ }^{529}$. Sin embargo, cuando finalmente el 14 de marzo se aprobó la ley universitaria 20.654 en la Cámara de Diputados con 142 votos a favor y sólo 15 en contra, los legisladores del FREJULI no tuvieron en cuenta ninguna de las propuestas de la JUP y ADUP. Los principales cambios a la normativa en su tratamiento legislativo procedieron del radicalismo y del mismo oficialismo ${ }^{530}$. Por petición de la UCR, se aceptó que el rector fuera elegido por las propias universidades y no por el poder ejecutivo como indicaba el proyecto original, aunque la representación de los distintos claustros en los órganos de gobierno continuó en proporción desigual: 60 por ciento para los docentes, 30 estudiantes y 10 no docentes (Art. $19^{\circ}$ y $33^{\circ}$ ). En esta cuestión, es relevante tener en cuenta que la normativa resultante no sólo garantizaba el co-gobierno, sino que confería a las universidades autonomía académica junto a una autarquía administrativa, económica y financiera (Art. $3^{\circ}$ ).

La otra modificación importante al proyecto de ley original provino del oficialismo,

\footnotetext{
528 “La Universidad. La JUP apoya la ley”, en Noticias, 24 de febrero 1974; "Posición de la JUP ante la ley universitaria", en La Nación, 24 de febrero 1974

${ }^{529}$ Según el diario de sesiones del congreso, 57 organismos, instituciones o personas presentaron trabajos o propuestas relacionadas con la ley universitaria. Además, se realizó una reunión con 24 partidos políticos el 21 de enero de 1974 y otra con organizaciones universitarias el 29 de enero. A su vez, se presentaron cuatro proyectos de ley aparte del oficial. Las universidades nacionales también elevaron sus propuestas, así como muchas de sus facultades, centros de estudiantes, agrupaciones docentes y no docentes. "Inserciones", en Cámara de Senadores de la Nación, 66 reunión, 15ª sesión extraordinaria, 7 y 8 de marzo 1974, pp. 3810-3825.

${ }^{530}$ La composición del congreso luego del 25 de mayo de 1973 fue la siguiente: en la Cámara de Senadores, el FREJULI contaba con 44 de un total de 69 miembros. En segundo lugar, la UCR con 12 senadores y por último una serie de partidos provinciales. En la Cámara de Diputados, el FREJULI también tenía la mayoría absoluta con 144 miembros sobre un total de 243, mientras la UCR tenía 51 diputados. Los bloques de ambas cámaras del FREJULI estaban compuestos por el PJ, el Movimiento de Integración y Desarrollo, el Partido Conservador Popular y el Partido Popular Cristiano. Para un análisis en profundidad de la composición de las cámaras y las distintas posturas que sostuvieron las fuerzas políticas ante la Ley Taiana, puede consultarse: Friedemann, S., Ob. cit., 2015, pp. 316-366.
} 
quien generalizó como una prohibición para todos los claustros de la universidad la cláusula que permitía la remoción de docentes por "proselitismo político partidario" o difundir "ideas contrarias al sistema democrático" (Art. $5^{\circ}$ ). Este punto renovaba el carácter restrictivo de la primera ley universitaria del peronismo (13.031) y de la normativa de Onganía para las casas de estudio $(17.245)^{531}$. A esto se sumaba que el texto legal que aprobó el congreso finalmente dio continuidad a la resolución que permitía la intervención de las casas de estudio por el poder ejecutivo en casos de "alteración grave del orden público", "conflicto insoluble", "subversión con los podes de la Nación”, entre otros (Art. 51).

Si bien la Ley Taiana fue aprobada por unanimidad en el senado y tuvo escasos votos en contra en la de diputados, los artículos $5^{\circ}$ y $51^{\circ}$ provocaron críticas en algunos legisladores del radicalismo, la Alianza Popular Revolucionaria (APR) y del peronismo ${ }^{532}$. Entre estos últimos, estaban Leonardo Bettanin, Miguel Zavala Rodríguez y Rodolfo Ortega Peña. Los tres ingresaron a la cámara un día antes de la aprobación de la Ley Taiana porque ocho diputados de la JP Regionales habían renunciado a sus bancas para no acatar la directiva de Perón de votar las reformas al Código Penal que endurecían las penas por delitos políticos ${ }^{533}$. Bettanin y Zavala Rodríguez pertenecían al sector juvenil vinculado a Montoneros. El primero había militado en los Comandos Estudiantiles Peronistas (CEP), uno de los grupos fundadores de la JUP. Por otro parte, Ortega Peña estaba vinculado al Peronismo de Base y dirigía Militancia Peronista para la Liberación, una revista crítica del gobierno que había publicado varias notas en defensa del rectorado de Puiggrós y el decanato de Kestelboim ${ }^{534}$. Esto no era casual, ya que Ortega Peña había tenido cargos de gestión en la UNPBA e incluso había sido profesor en las facultades de Filosofía y Letras y Derecho, hasta que fue apartado a

\footnotetext{
531 El artículo $4^{\circ}$ de la ley 13.031 establecía: "Los profesores y los alumnos no deben actuar directa, ni indirectamente en política, invocando su carácter de miembros de la corporación universitaria"; mientras el artículo 10 del decreto-ley 17.245 indicaba: "Prohíbase en los recintos universitarios, toda actividad que asuma formas de militancia, agitación, propaganda, proselitismo o adoctrinamiento de carácter político”. Mignone, E., Política y universidad. El Estado Legislador, Bs. As., Lugar Editorial, 1998, p. 27 y 46.

${ }^{532}$ La APR había llevado la fórmula Alende-Sueldo en la primera campaña presidencial de 1973. Estaba compuesta por el PC, el Partido Revolucionario Cristiano, el Partido Intransigente y la Unión del Pueblo Argentino. Era la tercera fuerza política con representación en la Cámara de Diputados. En ese momento, votó en contra de la ley universitaria.

${ }^{533}$ Los ocho renunciantes fueron Rodolfo Vittar, Roberto Vidaña, Carlos Kunkel, Armando Croatto, Santiago Díaz Ortiz, Diego Muñiz Barreto, Jorge Gleller y Aníbal Iturrieta. "Hoy entran los ocho diputados. Reemplazarán a los que renunciaron por aponerse a la ley represiva", en Noticias, 13 de marzo 1974.

${ }^{534}$ Tras su conocida jura -"la sangre derramada no será negociada”- Ortega Peña reemplazó a uno de los diputados renunciantes de la JP, pero en lugar de integrarse al bloque del FREJULI por el que resultó electo, decidió conformar un bloque unipersonal: "bloque de la base". Celesia, F., y Waisberg, P., La Ley y las armas. Biografia de Rodolfo Ortega Peña, Bs. As., Aguilar, 2013, p. 257-259; “Ortega Peña anunció que no integrará el bloque de diputados del Frejuli", en La Opinión, 14 de marzo 1974.
} 
fines de 1973 por aplicársele la ley de prescindibilidad a petición de Taiana ${ }^{535}$.

Los recién incorporados Bettanin y Zavala Rodríguez votaron la ley con el resto del bloque del FREJULI, pero mostraron su disconformidad con el artículo $5^{\text {o536 }}$. El segundo de ellos reconoció durante el debate en el congreso que la ley contemplaba avances y demandas de la juventud universitaria. Aunque le parecía "de más e innecesario" hablar de "proselitismo" dado que la educación tiene siempre un trasfondo político y que toda política se desarrolla desde un interés concreto ${ }^{537}$. Por su parte, desde su bloque unipersonal, Ortega Peña expresó una posición más crítica y votó en contra de la ley, aludiendo a su experiencia como "alumno, egresado, profesor universitario y como prescindido". A su entender, la normativa no cumplía con el "programa de liberación" elegido por el pueblo el 11 de marzo de 1973, ya que la prohibición de "actividades proselitistas" del artículo $5^{\circ}$ podía llevar a proscribir cualquier actividad política en la universidad. También acusaba al ejecutivo de mantener una "grave contradicción" porque en la nueva ley de asociaciones profesionales se había derogado la normativa anterior que excluía la política en los sindicatos. Más polémico aún le parecía el artículo $51^{\circ}$ dada la "peligrosísima" posibilidad de que el ejecutivo interviniera las universidades por decreto aludiendo a la idea de "subversión", un concepto tan "lato" y "ambiguo" que podía prestarse a cualquier interpretación. Finalmente, Ortega Peña sentenciaba que si era sancionada la ley traería "consecuencias casi inmediatas" en la medida que el "estudiantado reaccione",538.

Cuando se aprobó la Ley Taiana el 14 de marzo de 1974, todos los interventores de las universidades nacionales presentaron sus renuncias, incluidos los delegados de las facultades y Villanueva, el secretario general a cargo del rectorado de la UNPBA desde la renuncia de Puiggrós. Según la flamante legislación, el poder ejecutivo debía designar nuevos decanos y

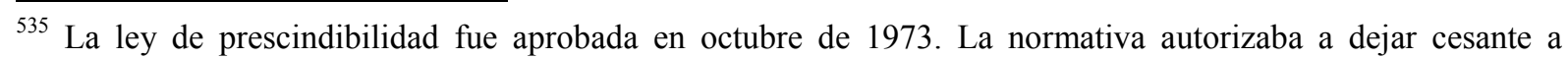
personal del Estado a criterio de las autoridades de cada dependencia y prohibía que el personal afectado volviera a ingresar a la administración estatal durante los siguientes cinco años. Taiana decidió aplicarla para los cargos que tenían Ortega Peña y Duhalde en las facultades de Derecho y Filosofía y Letras. Esto en gran parte se debía a la posición crítica al gobierno de la revista Militancia Peronista para la Liberación. Villanueva, Kestelboim, la JUP y ADUP intentaron oponerse, aunque finalmente fueron separados de sus cargos. Bufano, S. y Texidó, L., Perón y La Triple A. Las 20 advertencias a Montoneros, Bs. As., Sudamericana, 2015, pp. 165166.

${ }^{536}$ Ambos al poco tiempo serían separados del bloque del FREJULI por una petición de Alberto Brito Lima, el jefe del Comando de Organización. "Por moción de Brito Lima diputados de la JP fuera del bloque", en Noticias, 21 de marzo 1974.

${ }^{537}$ Todas las referencias al debate parlamentario corresponden a los diarios de sesiones de la Cámara de Senadores, 66 reunión, 16 a sesión extraordinaria, 7 y 8 de marzo 1974, pp. 3675-3809 y de la Cámara de Diputados, 65 Reunión, continuación de la 3 $3^{\mathrm{a}}$ sesión extraordinaria, 13 y 14 de marzo 1974, pp. 6295-6369.

${ }^{538}$ Para un análisis en mayor profundidad de las distintas posturas que giraron en torno al debate parlamentario de la Ley Taiana, también puede consultarse: Buchbinder, P., "La universidad y el tercer peronismo: notas sobre el debate parlamentario en torno a la Ley Taiana", en Millán, M. (comp.), Universidad, política y movimiento estudiantil en Argentina: entre la Revolución Libertadora y la democracia del '83, Bs. As., Final Abierto, 2014.
} 
rectores "normalizadores" para que en el plazo de un año las casas de estudio funcionaran de acuerdo a la nueva normativa. Al día siguiente, la JUP emitió un documento donde pedía que continúen en el cargo los funcionarios que venían desempeñándose hasta ese momento. A su vez, llamaba al estudiantado a movilizarse para impedir que la ley universitaria sea "instrumentada" por "sectores infiltrados" del gobierno que buscaban acabar con la política de “reconstrucción universitaria” iniciada por Puiggrós y seguida por Villanueva ${ }^{539}$ ¿Por qué ahora la JUP sentía como amenaza una normativa que reconocía buena parte de sus demandas en relación a la organización de la universidad? Este posicionamiento se explica por el contexto político particular de aquel entonces y porque las modificaciones introducidas a último momento a la ley lesionaban una concepción central de su ideario en relación al papel del estudiante en la universidad.

En relación al primer punto, no debe perderse de vista que la ley universitaria fue sancionada en un momento donde se profundizó el desplazamiento de actores vinculados a la izquierda peronista en distintas áreas de gobierno. En enero, Oscar Bidegain había sido obligado a renunciar a su cargo de gobernador de la provincia de Buenos Aires luego del asalto del ERP a una guarnición del ejército en la ciudad de Azul. Mientras que en febrero fue derrocado el primer mandatario de Córdoba, Ricardo Obregón Cano, mediante una asonada policial encabezada por Antonio Navarro ${ }^{540}$. Además, casi en simultáneo a la sanción de la Ley Taiana fueron sancionadas un conjunto de normas que afectaban derechos y libertades públicas. A fines de 1973, se habían aprobado la ley de asociaciones profesionales y la de prescindibilidad. La primera aseguraba a las centrales sindicales la posibilidad de intervenir las seccionales locales de los gremios y la segunda cesantear en el sector público de manera arbitraria. A ello se sumaba la reforma del Código Penal en enero de 1974 que incrementó las penas por delitos políticos ${ }^{541}$. En paralelo, la organización paraestatal Triple A había comenzado hacer públicas sus acciones, como en el atentando contra el senador radical Hipólito Solari Yrigoyen a fines del año anterior. En su "lista negra" de "enemigos a exterminar" también estaba el mismo Puiggrós.

En cuanto al segundo punto, la Ley Taiana incluía una cláusula que limitaba la

\footnotetext{
539 "La universidad al borde de la opción: liberación o continuismo gorila", El Descamisado, No 43, 12 de marzo 1974; "La JUP convocó a la movilización. En un documento, llama a los estudiantes a sostener en sus a cargos a las actuales autoridades", en Noticias, 16 de marzo 1974.

${ }^{540}$ Los trabajos de Pablo Bonavena y Alicia Servetto describen en detalle cómo fueron destituidos los distintos gobernadores vinculados a la Tedencia, mediante la presión del sector sindical, la derecha peronista y el propio Perón. Bonavena, P., "Guerra contra el campo popular en los setenta. Juan Domingo Perón, la depuración ideológica y la ofensiva contra los gobernadores”, en Izaguirre, I., Lucha de clases, guerra civil y genocidio en la Argentina 1973-1983, Bs. As., Eudeba, 2012; Servetto, A., 73/76 el gobierno peronista contra las "provincias montoneras", Bs. As., Siglo XXI, 2010.

${ }^{541}$ Franco, M., Ob. cit., 2012, p. 89.
} 
actividad política en la universidad y esto directamente lesionaba uno de los idearios centrales de la JUP. Si bien la agrupación liderada por Ventura reivindicó muchos puntos de la normativa, concebía a la participación política del estudiantado como condición ineludible para garantizar una presencia crítica que vinculara las problemáticas concretas de las casas de estudio con cuestiones políticas y sociales más amplias. En este tema era tributaria del Manifiesto de F.O.R.J.A a los estudiantes de la Universidad de Buenos Aires que había publicado Antropología 3er. Mundo en 1970 y que volvió a editar la revista Crisis en marzo de $1974^{542}$. Como vimos, este documento llamaba a recuperar un ideario central atribuido a la Reforma y sintetizado en el lema: "el estudiante de la universidad es trasfusión del pueblo en las aulas" ${ }^{543}$. En esta cuestión, es sugestivo que durante el debate de la Ley Taiana la JUP no invocó a ley universitaria 13.031 del primer peronismo, como sí lo hicieron los sectores del movimiento que cuestionaban a la JP Regionales y Montoneros. La revista Las Bases, el órgano oficial del MNJ que resaltaba la figura del ministro López Rega, publicó en aquel entonces una gran cantidad de notas dedicadas a esa cuestión e incluso la CNU durante el debate parlamentario había acercado al presidente del bloque de senadores del FREJULI, José Humberto Martiarena, una serie de documentos que pedían elaborar la nueva ley en base a la de $1947^{544}$. Justamente, el ordenamiento legal del primer peronismo había establecido que los universitarios sólo podían dedicarse a sus funciones específicas y no actuar directa ni indirectamente en política. La complejidad de la Ley Taiana radicó en que reconoció demandas de la izquierda peronista y el radicalismo, pero también abrió la puerta a los que buscaban acabar con la politización de las casas de estudio.

\section{V - DE LA DISIDENCIA A LA MISIÓN IVANISSEVICH}

\footnotetext{
542 "FORJA y el problema universitario", en Crisis, N 11, marzo de 1974. Crisis fue una publicación de política y cultura editada en la ciudad de Buenos Aires, pero que contenía un staff compuesto por intelectuales, periodistas y escritores de Argentina y Uruguay. Cuando salió su primer número en mayo de 1973, Federico Vogelius era su director ejecutivo, Eduardo Galeano el director editorial y Julia Constenla la secretaria de redacción. El artista plástico Hermenegildo Sábat fue el ilustrador de los cuarenta números que aparecieron todos los meses hasta agosto de 1976. En sus páginas, participaron Aníbal Ford, Juan Gelman, Mario Benedetti y Rogelio García Lupo. Sonderéguer, M. (comp.), Revista Crisis 1973-1976. Del intelectual comprometido al intelectual revolucionario, Bernal, UNQUI, 2011.

543 "FORJA y la Universidad", en Antropología 3.er Mundo, No 4, septiembre 1970, p. 62.

544 "Universidad: el proyecto de la CNU" y "Universidad: la posición del Consejo Superior" en Las Bases. Órgano oficial del Movimiento Nacional Justicialista, $\mathrm{N}^{\circ}$ 78, 22 de enero 1974. Además, pueden consultarse en la misma revista las siguientes notas sobre universidad: "Otro país, un país distinto y extraño", N 63, 10 de octubre 1973; "La Reforma: sus conquistas gremiales. Su instrumentación política", N 65, 24 de octubre 1973; "El peronismo abre auténticamente las aulas al pueblo", $N^{\circ} 67,7$ de noviembre 1973. "Las leyes peronistas", $N^{\circ}$ 68, 14 de noviembre 1973; "VI congreso Nacional de la C.G:U.", N 72, 12 de diciembre 1973; "Grave renuncia: atacan al gobierno del pueblo", N 73, 19 de diciembre 1973; "La hora del país real ha llegado", N 79, 5 de febrero 1974; "Hacia la universidad de los trabajadores. Los estudiantes ipor la ley!", № 85, 12 de marzo 1974 , entre otras.
} 
Luego de la sanción de la Ley Taiana se designó como rector normalizador de la UNPBA a Vicente Solano Lima, el referente del Partido Conservador Popular y ex vicepresidente de Cámpora que en ese momento encabezaba la Secretaría General de la Presidencia de la Nación. Como lo indicaba la normativa 20.654, debía estar al frente del rectorado hasta que se redactaran los nuevos estatutos y llamara a elecciones de claustros. Villanueva, por su parte, estaba imposibilitado de seguir al frente de la casa de estudio, dado que la nueva legislación establecía una edad mínima de 30 años para ser rector o vicerrector de una universidad nacional.

Solano Lima llegó al rectorado de la UNPBA cuando el campo de fuerzas políticas había comenzado a modificarse. Entre fines de 1973 y hasta su nombramiento a inicios del año siguiente, se desarrollaron dos procesos que contribuyeron a ello: la mayor presencia de grupos de derecha en las facultades y el surgimiento de disidencias al interior de la JP Regionales y Montoneros, las cuales se reflejaron en el ámbito universitario.

Los sectores de derecha eran minoritarios en relación a la izquierda peronista y no peronista, pero desde los últimos meses de 1973 tuvieron más visibilidad y sus apariciones se volvieron frecuentes. El 25 de octubre de ese año, la CNU, el Comando de Organización y la Juventud Sindical Peronista intentaron realizar un acto en la Facultad de Derecho para homenajear al líder de la CGT recientemente asesinado. En el mismo entronaron estribillos como "Rucci leal, te vamos a vengar", "Puiggrós: la JUP es bolche como vos" e insultos contra Kestelboim y Ortega Peña. Todo terminó con varios destrozos -entre ellos un monolito que recordaba a los muertos de Trelew- y duros enfrentamientos con la JUP, los cuales dejaron como saldo tiroteos y algunos heridos ${ }^{545}$. En 1974, poco tiempo antes de la asunción de Solano Lima, la CNU volvió a tener presencia en los medios a raíz de una nueva irrupción en las casas de estudio. El 18 de marzo ocuparon paralelamente el rectorado de la UNLP y la Facultad de Derecho porteña. Luego de ser desalojados, la FULNBA ocupó por su parte los establecimientos aludiendo la necesidad de impedir nuevas "tomas" y garantizar el "normal" funcionamiento de las actividades académicas ${ }^{546}$.

El otro tema importante a tener en cuenta para entender el contexto en que Solano Lima se hizo cargo de la UNPBA, está relacionado con las disidencias que surgieron al interior de la Tendencia Revolucionaria. Después del asesinato de Rucci, un conjunto de grupos comenzaron a distanciarse y a criticar el papel de Montoneros, el más importante fue

\footnotetext{
545 "Facultad de Derecho atacada por el gangsterismo", en Militancia Peronista para la Liberación, No 21, 1 de noviembre 1973.

546 "Copan dos sedes universitarias", en Noticias, 19 de marzo 1974; "Ocupaciones de facultades", en La Nación, 19 de marzo 1974; "Normal actividad en el ámbito universitario”, en La Nación, 20 de marzo 1974.
} 
el que se conoció como JP Lealtad. Su desprendimiento tomó estado público en el encuentro realizado el 3 de febrero de 1974 en el Club Sportivo Baradero, donde bajo el impulso del cura Jorge Galli, Eduardo Moreno y Patricio Jeanmaire se redactó un documento que rechazaba a la conducción nacional de la organización armada por darse "un proyecto propio" al margen de Perón y llamaba a "recuperar la JP",547. Aunque la existencia de Lealtad terminó de oficializarse el 14 de marzo cuando fue publicada en Clarín una solicitada titulada "La conducción de Montoneros es Perón”, en la cual se cuestionaba nuevamente el enfrentamiento con el líder y se lo reivindicaba como el "único conductor estratégico",548.

Esta ruptura de Montoneros y la JP Regionales tuvo su propia manifestación en el frente universitario. A fines de enero de 1974, se realizó un campamento de la JUP en Itacombú, un campo de Corrientes ubicado a orillas del río Paraná ${ }^{549}$. En ese encuentro, se produjeron fuertes debates internos que terminaron en la conformación de JUP Lealtad. La misma fue encabezada por Norberto Ivancich, un estudiante de sociología que había comenzado su militancia en el Movimiento Humanista Renovador y luego integrado los CEP, uno de los grupos fundadores de la JUP a inicios de 1973. Después de Itacombú, se sumaron al sector Lealtad algunos militantes de Medicina y Exactas, aunque el principal núcleo disidente se radicó en Económicas y Filosofía y Letras. En la primera tuvo un papel importante Lorenzo Donohoe, quien había formado con Ventura y Talento las Bases Peronistas a principios de los setenta, otra agrupación relevante que participó en el origen de la JUP ${ }^{550}$. Mientras en Filosofía y Letras, el principal referente de Lealtad era el presidente del centro de estudiantes Darío Alessandro, quien provenía de la Agrupación de Estudiantes Peronistas (AEP) del MRP.

La JUP Lealtad pudo reunir un conjunto de activistas, pero seguía siendo minoritaria frente al espacio que se referenciaba con la JP Regionales y Montoneros, el cual retuvo la mayoría de militantes y tenía su columna vertebral en las facultades de Derecho y Arquitectura. En esta última, estudiaban importantes activistas de la JUP, como Roberto Corvaglia y Alberto Bello ${ }^{551}$. El primero era presidente del centro de estudiantes y vocal de la

\footnotetext{
${ }^{547}$ Pozzoni, M., Proyectos, ideas y prácticas políticas de las juventudes peronistas de izquierda en el contexto de la cultura política argentina. Provincia de Buenos Aires 1970- 1976, Tesis de Doctorado, Universidad Nacional de Mar del Plata, Facultad de Humanidades, 2010, p. 233; Pozzoni, M., “'Leales' y 'Traidores': la experiencia de disidencia de la Juventud Peronista Lealtad (1973-1974)”, en Nuevos Mundos. Mundos Nuevos, junio 2013. 548 “La conducción de Montoneros es Perón”, en Clarín, 14 de marzo 1974.

${ }^{549}$ Anguita, E. y Caparrós, M., La Voluntad. Una historia de la militancia revolucionaria en la Argentina 19731976, Bs. As, Planeta, Tomo II, 2013, p. 225.

${ }^{550}$ Entrevista a Lorenzo Donohoe, C.A.B.A., 27/01/2016.

${ }^{551}$ Entrevista a Roberto Corvaglia, C.A.B.A., 11/09/2015; Corvaglia, R., "La militancia al servicio de la causa nacional y popular en los claustros universitarios", en Baschetti, R., Peronistas que estudian. De los libros de lectura a la lectura de la realidad, Bs. As., Jironesdemivida, 2016, pp. 186-191.
} 
FULNBA y el segundo formaba parte de la conducción de la Regional I de la JUP. A su vez, en la casa de estudio dirigida por Kestelboim, estaban los ya nombrados Ventura, jefe de la Regional I e integrante de la Mesa Nacional de la JUP, y Talento, el presidente de la FULNBA. Los primeros cruces entre los dos sectores se produjeron en el contexto de la sanción de la Ley Taiana. Los "leales" manifestaron en todo momento su respaldo a la iniciativa y acusaron a la agrupación de Ventura de retornar a la tradición "liberal y reformista" al crear un "frente opositor" al gobierno con radicales y comunistas ${ }^{552}$. Por su parte la JUP, en el mismo documento que hizo conocer el 15 de marzo para denunciar que la ley universitaria iba a ser "instrumentada" contra la UNPBA, acusaba de "oportunismo" a "personas que hasta hacía poco tiempo pertenecían a su organización” y sólo querían “confundir al movimiento estudiantil", quedándose con cargos universitarios "a costa de la traición" $" 553$.

La división de la JUP volvió a manifestarse el mismo día de la asunción de Solano Lima. Después de sancionada la Ley Taiana y anunciado su nombramiento oficial con el decreto 949, el secretario de la presidencia finalmente asumió como rector el 2 de abril ${ }^{554}$. A la ceremonia, sólo concurrieron militantes de la JUP Lealtad y estuvieron ausentes las tres fuerzas principales que conformaban la FULNBA: la JUP, FM y el MOR. Durante el acto, los "leales" entonaron adhesiones al nuevo rector -“Lima, Perón, un solo corazón”- y duras consignas contra Villanueva, el funcionario saliente -“Apoyo a los leales, amasijo a los traidores" $", 555$. Sin embargo, la ausencia de la JUP estaba lejos de significar una actitud de prescindencia con la nueva gestión que se iniciaba. Al contrario, estaba en un compás de espera para ver si eran cumplidas las principales demandas que había reclamado a Solano Lima unos días antes. El 28 de marzo, la JUP, el resto de la FULNBA y la Federación de Trabajadores Docentes Universitarios de la Universidad de Buenos Aires (FATDUBA) habían efectuado una concentración en la Facultad de Medicina y luego se dirigieron a la casa del rector ${ }^{556}$. Ya en ella, Ventura y Talento se entrevistaron con él, le dejaron un "Acta de

\footnotetext{
${ }_{552}^{50}$ Rodríguez, L. G., Universidad, Peronismo y Dictadura 1973-1983, C.A.B.A, Prometeo, 2015, p. 40.

553 "La JUP convocó a la movilización. En un documento, llama a los estudiantes a sostener en sus a cargos a las actuales autoridades", en Noticias, 16 de marzo 1974.

${ }_{554}$ Decreto No 949, Bs. As., 23/03/1974, en Boletín Oficial de la República Argentina, № 22885, Año LXXXII, miércoles 3 de abril 1974; "Solano Lima: revolución sin sangre. Asumió como rector de la universidad y pidió siembra de ideas", en Noticias, 3 de abril 1974.

555 "Los hechos de la quincena", "Ya hemos volteado 28 generales" y "Solano lima asperezas en la universidad", en Movimiento, $\mathrm{N}^{\circ} 0$, segunda quincena abril 1974.

${ }^{556}$ FATDUBA fue creada a fines de 1973 por impulso de ADUP, luego de triunfar en la mayoría de elecciones docentes durante ese mismo año. Según la propia agrupación, FATDUBA contaba con 580 afiliados en Filosofía y Letras, 550 en Arquitectura, 250 en Farmacia y Bioquímica, 300 en Ciencias Exactas, 350 en Derecho, 300 en Ingeniería y 60 en Ciencias Económicas. "Reportaje a los compañeros de ADUP”, en Boletín de la Universidad Nacional y Popular de Buenos Aires, Dirección de Prensa y Difusión, 22 de noviembre 1973.
} 
compromiso estudiantil-docente" y le reclamaron que continuara la línea de gobierno iniciada por Puiggrós y que permanecieran en sus cargos Villanueva, Kestelboim, Ibarlucía, Laguzzi y O’Farrell ${ }^{557}$.

Solano Lima finalmente accedió a la demandas y confirmó a Villanueva en el cargo de secretario general de la UNPBA ${ }^{558}$. A su vez, designó como decanos normalizadores a Kestelboim en Derecho, a Laguzzi en Farmacia, a Ibarlucía en Arquitectura y a O' Farrell en Filosofía y Letras ${ }^{559}$. A los pocos días, no obstante, Adriana Puiggrós reemplazó a este último en la conducción de la facultad. De todas maneras, eso no significó un cambio de orientación ya que la hija del ex rector de la UNPBA militaba en ADUP y se venía desempeñando en la gestión de O'Farrell como directora del Departamento de Ciencias de la Educación. En su asunción, el día 25 de abril, se manifestó hasta qué punto podía llegar la disputa interna con los sectores "leales". Durante el acto, se produjo un tiroteo entre ambas fracciones de la $\mathrm{JUP}^{560}$. A ello se sumó la separación de integrantes de la JP Lealtad de sus cargos docentes y de gestión, como los casos de Roberto Marafioti, quien había sido hasta ese entonces el secretario de extensión, y de Alcira Argumedo ${ }^{561}$.

Sin embargo, otras designaciones de decanos normalizadores que efectuó Solano Lima manifestaban cierta redistribución de poder en las facultades. Un caso fue el de Ingeniería, donde Enrique Martínez, integrante del Consejo Tecnológico de Rolando García, fue reemplazado en el decanato por Jorge Roulet, un radical que en sus años de estudiante durante el primer peronismo había sido presidente de la FUBA y de la FUA ${ }^{562}$. Su designación se debía a dos factores: el acuerdo entre el FREJULI y la UCR por la aprobación de la Ley Taiana y porque en esa casa de estudio dominaba FM el panorama estudiantil. Al frente del histórico centro de estudiantes "La Línea Recta”, estaba Miguel Ponce de la JRR ${ }^{563}$. Por otra parte, también es importante tener en cuenta que Solano Lima renovó el cargo de Oscar Sbarra Mitre en Ciencias Económicas, uno de los decanos referenciados con la JP Regionales

\footnotetext{
557 “Universidad. Movilización en defensa de la actual política”, en Noticias, 28 de marzo 1974; "Los estudiantes de varias universidades se movilizan en apoyo de actuales autoridades", en Noticias, 29 de marzo 1974; "La FULNBA habló con el nuevo rector", en Noticias, 30 de marzo 1974; "Fijaron su posición grupos estudiantiles", en La Nación, 29 de marzo 1974; "Expectativas ante la gestión que se inicia”, en La Nación, 30 de marzo 1974; "Ponen en funciones a los rectores", en La Nación, 30 de marzo 1974.

558 "Villanueva aceptó continuar en la Secretaría, en Noticias, 2 de abril 1974.

559 Las renuncias tras la sanción de la ley universitaria y las nuevas designaciones de Solano Lima pueden consultarse en: Res. (C.S.) No 470 a 477, UBA, 28 de marzo 1974; No 2 y 3, UBA, 4 de abril 1974; $\mathrm{N}^{\circ} 10,16$ y 17, UBA, 8 de abril 1974.

560 “Quincena 1. Los hechos", en Movimiento, No 1, primera quincena mayo 1974.

561 Entrevista a Roberto Marafioti, C.A.B.A., 06/01/2016 y 19/01/2016; Entrevista a Alcira Argumedo, C.A.B.A., 01/11/2012.

${ }_{562}$ La trayectoria de Roulet puede consultarse en: www.fundacionroulet.org.ar.

${ }^{563}$ Entrevista a Miguel Ponce, C.A.B.A., 20/11/2015 y 27/11/2015.
} 
que luego de la ruptura adhirió públicamente a Lealtad ${ }^{564}$. Más aún, todo su equipo de gestión, como la JUP y ADUP de esa casa de estudio, pasó a formar parte de la disidencia a Montoneros. Junto a Sbarra Mitre tuvo un papel importante Horacio Fazio, su secretario académico, quien provenía de una militancia cristiana y había integrado años atrás los CEP con Ivancich, el referente de JUP Lealtad ${ }^{565}$.

La Facultad de Ciencias Económicas se constituyó así en uno de los principales puntos de referencia y encuentro de los sectores "leales". El 28 de abril, se realizó en sus instalaciones el Primer Congreso Regional de la JP Lealtad, al que asistieron más de 400 delegados de Capital, Buenos Aires, Corrientes, Rosario, Santa Fe y Neuquén. En el mismo se convocó al acto por el día del trabajador que iba organizarse en Plaza de Mayo y se pusieron en común una serie de puntos para impulsar el "reagrupamiento de la JP”. Según Movimiento, la revista dirigida por Miguel Saiegh para impulsar la línea política de Lealtad, entre los ejes consensuados estaban la defensa al "gobierno popular", el repudio a propuestas "alternativistas" a la conducción de Perón, la "erradicación de la violencia" para dirimir disputas internas y la necesidad de impedir la polarización del peronismo ${ }^{566}$. Para poner en práctica estos objetivos, se conformó la Coordinadora Provisoria de la JP Lealtad, la cual fue integrada por delegados de distintas zonas y referentes de algunos frentes, como el nombrado Ivancich (JUP), Horacio González (Capital), Edmundo González (Gran Buenos Aires Norte), José Canalls (Sur), Ricardo Gómez (Oeste), Mario Maidovani (UES), Mario Cisneros (provincia de Buenos Aires), Enrique Vallejos (Santa Fe), Roberto Hyon (Rosario) y Víctor Espinosa (Corrientes) ${ }^{567}$.

En relación a los sectores universitarios disidentes, no sólo es importante resaltar que Ivancich integraba la coordinadora, sino también Horacio González, el ex integrante de las CN que desde 1973 era profesor de Ciencias Económicas. En esa facultad, estaba a cargo de la materia introductoria titulada Historia Nacional y Popular, en cuyo cuerpo docente participaba Arturo Armada, un ex militante del MHR. Ambos se conocían por haber formado

\footnotetext{
${ }^{564}$ Pueden encontrarse testimonios de Sbarra Mitre en relación a la JP Lealtad en: Duzdevich, A., La lealtad: los montoneros que se quedaron con Perón, Bs. As., Sudamericana, 2015, pp. 216-217.

${ }^{565}$ Entrevista a Horacio Fazio, C.A.B.A., 09/12/2015.

566 "Leales a Perón. Se reagrupan los jóvenes peronistas escindidos de la Tendencia", en Movimiento, № 1 , primera quincena mayo 1974. El nombre completo de la revista que dirigió Miguel Saiegh era Movimiento para la Reconstrucción y Liberación Nacional. La misma no constituyó un órgano de difusión formal, sino que fue producida por un grupo de periodistas y militantes que buscaban difundir los debates que estaban dispersos en las distintas redes que se iban separando de la JP Regionales y Montoneros. Slipak, D., Las Revistas Montoneras. Cómo la organización construyó su identidad a través de sus publicaciones, Bs. As., Siglo XXI, 2015, p. 168.

567 "Surgió un nuevo sector en las huestes juveniles peronistas. La propuesta de la JP-Lealtad es afianzar la línea doctrinaria", en La Opinión, 30 de abril 1974.
} 
parte de la revista Envido. El primero como su director y el segundo como miembro del consejo editorial, que además integró Fazio e incluso Sbarra Mitre colaboró con una nota para su octavo número ${ }^{568}$. Envido había dejado de salir en diciembre de 1973, pero en su último número había anticipado las posiciones de los sectores ligados a JP Lealtad ${ }^{569}$. Como adelantamos en el capítulo anterior, la revista de Armada nunca se presentó como un proyecto orgánico de una agrupación política, aunque reflejó el itinerario de jóvenes intelectuales ligados a la Tendencia Revolucionaria. A principios de 1973, surgió una propuesta de parte de Jorge Bernetti de vincular la publicación a Montoneros; la mayoría de sus integrantes estuvieron de acuerdo y otros se negaron. Esto provocó el alejamiento de José Pablo Feinmann, Miguel Hurst, Héctor Abrales, Santiago González y Eduardo Clausen. De todas maneras, la relación no prosperó debido a la indiferencia de la organización armada y porque el asesinato de Rucci terminó alejando a casi todos de su línea política ${ }^{570}$.

El último número de Envido, en el cual las notas fueron publicadas sin firmas, contenía un artículo titulado "Esbozos críticos sobre algunas concepciones en el seno del peronismo". En él se planteaba el concepto de una "ortodoxia activa" que se diferenciaba de una "heterodoxia alternativista". Estas categorías vaticinaron lo que sería el enfoque de Lealtad hacia la JP Regionales y Montoneros. La "ortodoxia activa” planteaba una adhesión "indiscutible” hacia el conductor en tanto éste expresaba la unidad y los intereses de los sectores populares. La liberación nacional y social sólo podría realizarse a través suyo. Sin embargo, esa "lealtad" funcionaba como un "instrumento revolucionario del peronismo" por su carácter "activo". No era una subordinación pasiva al líder, sino una fidelidad que tenía que "sugerir, criticar y recrear" la conducción en el nivel de las organizaciones y de los cuadros ${ }^{571}$.

A su entender, esta postura se diferenciaba tajantemente de la "heterodoxia alternativista", la cual era criticada por dejar de lado "herramientas doctrinarias forjadas en la historia del peronismo" y por erigirse como una vanguardia por encima del movimiento e

\footnotetext{
${ }^{568}$ Sbarra Mitre, O., "Poder político popular y distribución del ingreso", en Envido, No 8, marzo 1973.

569 El último número de Envido si bien registra impreso el mes de noviembre, recién pudo distribuirse en diciembre de ese mismo año. Entrevista a Arturo Armada por Norberto Raffoul y Rodolfo Beltramini, 19/04/2008, en Envido. Revista de política y ciencias sociales, edición facsimilar de la Editorial de la Facultad de Filosofía y Letras, UBA, 2010, pp. X-XI.

${ }^{570}$ Entrevista a Arturo Armada, C.A.B.A., 15/12/2015 y 29/12/2015; Entrevista a Jorge Luis Bernetti, C.A.B.A, 06/02/2016. Además, puede consultarse en la revista El Ojo Mocho la polémica entre Horacio González, Feinmann y Armada que, entre otras cosas, repasa la disolución de Envido. El ojo mocho, $\mathrm{N}^{\circ} 16$, verano 20012002. En trabajos o testimonios actuales de los protagonistas también hay más referencias sobre la cuestión: Feinmann, J. P., Peronismo. Filosofia politica de una persistencia argentina, Bs. As., Planeta, 2011, Tomo II, pp.705-706; Feinmann, J. P. y González, H., Historia y pasión. La voluntad de pensarlo todo, Bs. As., Planeta, 2013.

571 "Esbozos críticos sobre algunas concepciones en el seno del peronismo", en Envido, № 10, noviembre 1973, pp. $48-57$.
} 
incluso del mismo Perón ${ }^{572}$. Al tener Envido una fuerte difusión en el ámbito universitario, su décimo número contribuyó a instalar el debate en estos espacios y a otorgar una base de sustento para la disidencia posterior. No era casual que en el discurso de JP Lealtad se tratara de "alternatisvista" la posición de Montoneros. Exceptuando a Bernetti, la mayoría de los miembros de Envido tuvieron relación o terminaron integrando los sectores "leales" Feinmann y Hurst sacaron una revista en julio de 1974 titulada Aluvión. Su único número salió una vez muerto Perón y contenía un editorial que expresaba hasta donde podía llegar su idea de lealtad y sus críticas a Montoneros: "El 1 de julio quedó atrás. El dolor, el estupor, la impotencia, la furia [...]. Se equivocarán quienes pretendan ofrecer su propia organización como reemplazo de la conducción que ejercía el general. Porque el general la dejó a Isabel. Y porque Isabel va a conducir, ${ }^{574}$.

\section{LA NUEVA NOCHE DE LOS BASTONES LARGOS}

A la ruptura definitiva entre Perón y Montoneros en el acto del día del trabajador realizado el 1 de mayo de 1974, le siguió al mes siguiente la partida del viejo líder del peronismo. El 1 de julio a horas de anunciarse su muerte, la Secretaría de Prensa y Difusión de la Presidencia afirmó que el poder ejecutivo había aceptado a Solano Lima la renuncia a sus dos cargos: el de secretario general de la Presidencia y el de rector normalizador. El líder del Partido Conservador Popular no hizo públicos sus motivos ${ }^{575}$. Al poco tiempo, Taiana le pidió que continuase en la UNPBA. Entre idas y vueltas, Solano Lima obtuvo una licencia y Laguzzi, el decano de Farmacia referenciado con la JP Regionales, fue nombrado interinamente como rector normalizador. Finalmente, la dimisión de Solano Lima se hizo efectiva, con lo cual Laguzzi quedó al frente de la casa de estudio porteña, al ser nombrado por Taiana el 24 de julio ad-referéndum del poder ejecutivo ${ }^{576}$.

Sin embargo, la asunción de Isabel Perón volvió el panorama más adverso aun para la izquierda peronista. El 14 de agosto fue reemplazado Taiana por Oscar Ivanissevich en el

\footnotetext{
${ }^{572}$ Ibídem, pp. 48-57.

${ }^{573}$ Para los vínculos entre Envido y la JP Lealtad, también puede consultarse: Pozzoni, M., “'Una mirada sobre la militancia en los primeros años '70 a través de la revista Envido (1970-1973)", en Nuevos Mundos. Mundos Nuevos, enero 2012.

574 "Perón vive", en Aluvión, № 1, julio 1974, pp. 1-2. Una cuestión importante a tener en cuenta es que la JP Lealtad no llegó a consolidar una conducción y una estructura orgánica que le permitiera mantenerse en el tiempo. A su vez, existieron desacuerdos en las filas "leales" a la hora de caracterizar a Isabel. Por estos y otros factores, la JP Lealtad terminó por disolverse a fines de 1974. Slipak, D., Ob. cit., 2015, p. 168.

575 “¿Renunció Solano Lima?”, en Noticias, 2 de julio 1974; "Lima abandonaría indeclinablemente la Universidad", en La Opinión, 6 de julio 1974.

576 "Lima se va, nomás", en Noticias, 25 de julio 1974; "Laguzzi afirmó que no variará la política universitaria", en La Opinión, 26 de julio 1974; "El doctor Lima deja hoy la Universidad de Buenos Aires", en La Opinión, 25 de julio 1974.
} 
Ministerio de Cultura y Educación ${ }^{577}$. El flamante funcionario era un representante del nacionalismo católico de derecha con una extensa trayectoria tras de sí. Había sido rector interventor de la UBA por un breve lapso en 1946 y ocupado el Ministerio de Educación durante el primer peronismo. Desde entonces pensaba que los estudiantes no debían hacer política y se declaraba enemigo de la Reforma del ' $18^{578}$. El mismo día de su designación, la FULNBA y FATDUBA realizaron una movilización y ocuparon facultades pidiendo que se garantizara la continuidad de Laguzzi, pero también la de Taiana. A su vez, rechazaron la posible designación de Rodolfo Tercera de Franco como rector y sostuvieron que iban a continuar con las "tomas" para garantizar el normal funcionamiento de las casas de estudio y que éstas no sean atacadas por "grupos reaccionarios"

A esto se sumaron nuevos alejamientos de funcionarios de la UNPBA cercanos a la JUP y ADUP. Luego de emprender una serie de acciones armadas, el 6 de septiembre Montoneros anunció su pasaje a la clandestinidad en una conferencia de prensa en la que Mario Firmenich fue acompañado por los distintos referentes de los frentes de masas de la JP Regionales, entre ellos estaba Ventura en representación de la $\mathrm{JUP}^{580}$. Esto desencadenó la inmediata renuncia del decano de la Facultad de Derecho. El propio Kestelboim difundió públicamente los motivos de su renuncia en un comunicado donde afirmaba que se "negaba a ser instrumento de esa política" y que no podía aceptar que la JUP, "una de las corrientes principales que sostuvo su gestión", le declarara la "guerra" al gobierno ${ }^{581}$. El 9 de septiembre, el rectorado de la UNPBA decidió aceptar su dimisión y nombró interinamente a Leonardo Franco, un docente de la facultad que había participado con Kestelboim en la Asociación Gremial de Abogados y en la Agrupación de Abogados Peronistas ${ }^{582}$.

Desde la asunción de Ivanissevich, se venía vaticinando una posible intervención de la UNPBA. La Causa Peronista, el órgano de prensa oficial de Montoneros y la JP Regionales que reemplazó a El Descamisado luego de su clausura, publicó una nota a principios de septiembre en la que acusaba al gobierno de Isabel de preparar una "nueva noche de los bastones largos" ${ }^{\$ 53}$. El propio ministro de Educación se encargó de despejar esta cuestión. En un discurso que brindó en el Teatro Colón el 10 de septiembre por el día del maestro, sostuvo que el artículo $5^{\circ}$ de ley universitaria, el cual prohibía el "proselitismo político partidario" y

\footnotetext{
577 "Hay nuevo gabinete", en Noticias, 15 de agosto 1974.

${ }^{578}$ Besoky, Ob. cit., 2016, p. 283.

579 "Fueron ocupadas las facultades anoche", en La Nación, 14 de agosto 1974; "Despliegue policial para impedir el acto de la FULNBA”, en Noticias, 15 de agosto 1974.

580 "Montoneros pasó a la resistencia activa", en La Nación, 7 de septiembre 1974.

581 "Renunció el decano de Derecho", en La Nación, 10 de septiembre 1974.

${ }^{582}$ Res. (C.S.), UBA, No 704 y 705, 10 de septiembre 1974.

583 "Preparan una nueva noche de los bastones largos", en La Causa Peronista, No 9, 3 de septiembre 1974.
} 
las "ideas contrarias al sistema democrático", no se estaba cumpliendo. Además, advirtió que "estaban dadas las causas" establecidas por esa misma normativa para intervenir las universidades. Para Ivanissevich, los estudiantes no estaban ocupando las facultades para protegerlas, sino que las usaban para la "subversión" y para atacar directamente la "jerarquía del Estado y la integridad de la República”. A su entender, lo que se imponía era el cierre de las universidades para "asearlas, ordenarlas y normalizarlas", dado que no se estaba ante un "conflicto universitario", sino ante una "batalla a muerte" contra una "conjura internacional" que pretendía "destruir la patria de Perón y la fe cristiana"

Como última señal de resistencia, el 14 de septiembre el rector Laguzzi y el secretario general Villanueva convocaron en una conferencia de prensa a los tres claustros universitarios -docentes, estudiantes, no docentes- a un plebiscito obligatorio a realizarse el 19 y 20 de ese mismo mes en todas las casas de estudio; con el fin de que se pronunciaran en relación a si avalaban o no la política universitaria impulsada desde la asunción de Puiggrós hasta la fecha. A su vez, acusaban a Ivanissevich de tener una concepción similar a los "adictos a las dictaduras militares" por su rechazo a la participación política universitaria ${ }^{585}$. Finalmente, el plebiscito no pudo llevarse adelante debido a que a los tres días de la conferencia de prensa fue intervenida la casa de estudio porteña con el decreto 865 de la presidenta Isabel Perón. En sus considerandos, la medida afirmaba que "era público y notorio" que estaban dadas las causales de intervención previstas por el artículo $51^{\circ}$ de ley 20.654 , entre las que se encontraban la "alteración del orden público" y la "subversión"586. Para llevar adelante la tarea, se designó a Alberto Ottalagano como nuevo rector interventor, un abogado y doctor en filosofía que había sido asesor de Perón en su último mandato y se asumía abiertamente como fascista y antimarxista. En su adolescencia, había sido delegado de la Alianza Libertadora Nacionalista y durante los años del primer peronismo había intervenido en la fundación de la $\mathrm{CGU}^{587}$.

Con el arribo de Ivanissevich y Ottalagano dejó de nombrarse a la casa de estudio porteña como la "Universidad Nacional y Popular de Buenos Aires". Sin embargo, sería un error entender su llegada como un punto de quiebre total, ya que la designación de ambos tenía elementos de continuidad con el proceso abierto a partir de la sanción de la Ley Taiana.

\footnotetext{
${ }^{584}$ Ivanissevich, O., "Mensaje de su Excelencia el señor Ministro de Cultura y Educación doctor Oscar Ivanissevich. 10 de setiembre de 1974", Ministerio de Cultura y Educación, Centro Nacional de Documentación e Información Educativa, Bs. As., 1974.

585 "Habrá un plebiscito en la Universidad", en La Nación, 14 de septiembre 1974; "El nucleamiento radical aspira a preservar la actividad académica", en La Opinión, 17 de septiembre 1974.

${ }^{586}$ Decreto $\mathrm{N}^{\circ}$ 865, Bs. As., 17/09/1974, en Boletín Oficial de la República Argentina, № 22999, Año LXXXII, lunes 23 de septiembre 1974.

${ }^{587}$ Ottalagano, A., Soy fascista. ¿Y qué? Una vida al servicio de la patria, Bs. As, ROCA Producciones, 1983.
} 
La aprobación de esta normativa había terminado otorgando herramientas legales para combatir al activismo político y creando condiciones para el fortalecimiento de actores que pensaban que el "peligro subversivo" debía ser erradicado con métodos legales e incluso extra legales. En el caso de la UBA, esta última cuestión resultó paradigmática si se tiene en cuenta la represión sufrida por la militancia estudiantil y el desplazamiento de las autoridades y los docentes de la izquierda peronista.

Estos últimos sufrieron atentados al poco tiempo de ser nombrado Ivanissevich. El 4 de septiembre fueron colocados explosivos en la casa de Adriana Puiggrós y el 7 en la de Laguzzi, lo cual dejó como saldo la muerte de su hijo de seis meses ${ }^{588}$. Un día antes de este hecho, la revista El Caudillo publicó una nota titulada "Cuentas claras política espesa". En ella se criticaba a Solano Lima por "haber entregado todo al marxismo loco de Laguzzi y sus adláteres”. Además de responsabilizar a éste y a Adriana Puiggrós - “una marxista de triste apellido"- de haber convertido a la universidad en un "nido subversivo" y en una "escuela del ridículo político". A su entender, la única solución era una "cirugía mayor" para acabar de una vez con el "último bastión" que conservaba la Tendencia ${ }^{589}$. Este órgano de prensa de la derecha peronista era dirigido por Felipe Romero y financiado con publicidad del Ministerio de Bienestar Social que encabezaba López Rega, el líder de la Triple A. En su distribución y realización, colaboraban miembros de la CNU y de la Juventud Peronista de la República Argentina (JPRA) $)^{590}$.

Cuando se hizo cargo Ottalagano del rectorado de la UBA declaró asueto y dejó cesantes a todos los decanos, funcionarios y docentes nombrados desde la asunción de Puiggrós ${ }^{591}$. Luego designó nuevas autoridades en las facultades: Mario José Framiñan en Odontología, José Penna en Ciencias Económicas, Jorge Antonio Antelo en Medicina, Lucas Tortoreli en Agronomía, Raúl Zardini en Ciencias Exactas y Rául Sánchez Abelenda en Filosofía y Letras. Este último recorrió las instalaciones de su facultad con una rama de olivo

\footnotetext{
588 "Solidaridad con Puiggrós", en La Opinión, 5 de septiembre 1974; Puiggrós, A., "La universidad del '73. Trascripción de una entrevista realizada a la Dra. Adriana Puiggrós", en Testimonios. A 25 años del golpe, CABA, FUBA/UBA/Página 12, 2000, pp. 69-77.

${ }_{589}$ "Cuentas claras y política espesa", en El Caudillo, No 42, 6 de setiembre 1974.

${ }^{590}$ La JPRA fue liderada por Julio Yessi, quien en 1973 había sido nombrado por Perón como representante de la JP en el Consejo Superior del MNJ, con el objetivo de aglutinar a los sectores juveniles diferenciados de Montoneros. Juan Alfredo Muciaccia, un ex militante del Movimiento Federal que conoció a Perón por intermedio de Yessi, era el secretario general. En una entrevista brindada a El Caudillo a fines de 1973, reconocía a la JPRA como un organización que pretendía institucionalizar la "revolución peronista" con "fanatismo", incluso llegando hasta las "últimas consecuencias". Besoky, Ob. cit., 2016, p. 213; "Reportaje al compañero Juan Muciaccia (Secretario General de la J.P. de la R.A.)", en El Caudillo, No 5, 14 de diciembre 1973.

591 "Prolongan en siete días el asueto universitario", en La Nación, 21 de septiembre 1974.
} 
para exorcizar los "malos espíritus de Freud, Marx y Piaget"592. Mientras Zardini había sido uno de los decanos más cuestionados por el movimiento estudiantil en los años de la "Revolución Argentina", por ser defensor de los cupos y el examen de ingreso eliminatorio. En 1972, la revista Ciencia Nueva lo había caracterizado como "el decano de la inquisición” y de ser un "oscurantista anticomunista" "593.

Antes de la llegada de Ivanissevich y Ottalagano, la Triple A ya había amenazado a integrantes de la UNPBA e incluso asesinado a Ortega Peña el 31 de julio de 1974. Pero luego de sus designaciones, las intimidaciones se multiplicaron. El 20 de septiembre, después de asesinar a Julio Troxler -un antiguo militante de la resistencia peronista que había sobrevivido a la masacre de José León Suárez en 1956- la Triple A difundió una "lista negra" en la que figuraban Cámpora, Firmenich, Bettanin, Taiana, Villanueva y Laguzzi. Este clima llevó a muchos ex integrantes de la UNPBA a la decisión de abandonar el país, como en el caso de Rodolfo Puiggrós, su hija Adriana, Testa, Ibarlucía y Laguzzi.

El arribo de Ivanissevich y Ottalagano también implicó un oscuro panorama para los militantes estudiantiles. Desde la UBA, se desplegaron medidas con la finalidad de acabar con su activismo político. El 1 de noviembre, El Caudillo realizó una entrevista al teniente coronel Antelo, el interventor de Medicina, en la cual advertía a la "muchachada estudiantil" que la facultad "estaba para estudiar y que toda otra actividad será dirigida hacia donde corresponde" ${ }^{, 594}$. A principios de octubre, luego de que Isabel firmara la ley antisubversiva, Ottalagano había creado un "cuerpo de celadores" bajo la dirección de Jaime Lemos, hombre de confianza de López Rega y funcionario del Ministerio de Bienestar Social ${ }^{595}$. Sus integrantes portaban armas de fuegos y vigilaban los pasillos de las facultades para que se cumpliera la prohibición de realizar cualquier tipo de asambleas o la aplicación de amonestaciones por participar en marchas o en huelgas ${ }^{596}$.

El decreto 865 que firmó Isabel para intervenir la UBA designaba a Ottalagano como

\footnotetext{
592 Puiggrós A., "El '73”, en El lugar del saber. Conflictos y alternativas entre educación, conocimientos y política, Bs. As., Galerna, 2003, p. 337.

593 "El decano de la inquisición”, en Ciencia Nueva, № 16, mayo 1972.

594 "Facultad de Medicina: aquí también llegó el peronismo", en El Caudillo, № 48, 1 de noviembre 1974.

${ }^{595}$ Como ley antisubversiva se conoció la Ley de Seguridad enviada por el poder ejecutivo al congreso el 25 de septiembre de 1974 y promulgada por Isabel Perón unos días después. La misma implicaba una fuerte constricción de la actividad política y violaba el derecho a huelga sancionado por la Constitución Nacional. También entre sus castigos previstos, se encontraba la suspensión de la ciudadanía y la expulsión del país. La dictadura de 1976 retomaría al pié de la letra toda la ley antisubversiva de 1974. Franco, M., Ob. cit., 2012, pp. 118-119. En relación a las medidas represivas instrumentadas por Ottalagano en la UBA, también puede consultarse: Friedemann, S., Ob. cit., 2015, pp. 425-437.

596 "Promulgóse la ley antisubversiva", en La Nación, 1 de octubre 1974; "Señaló Ottalagano los objetivos de su gestión, en La Nación, 4 de octubre 1974; "Está contemplada la desaparición de los cuerpos de celadores en las Facultades", en La Opinión, 31 de diciembre 1974.
} 
interventor hasta 31 de diciembre de 1974, por lo cual luego de esa fecha fue reemplazado por Julio Lyonnet. En los más de tres meses de gestión de Ottalagano fueron asesinados 15 estudiantes porteños ${ }^{597}$. Un mes antes de su salida del rectorado, la FULNBA había aplazado la realización de los comicios estudiantiles "hasta que existan condiciones favorables" e intentado llevar adelante un plebiscito para pedir el relevo del ministro, el rector y los 11 decanos de las facultades. La respuesta del gobierno ante ese intento fue nuevamente la represión y el encarcelamiento de dirigentes estudiantiles. El 22 de noviembre fueron detenidos Ventura y Talento en Villa Devoto ${ }^{598}$. Luego de pasar unos meses en la cárcel, ambos partieron al exilio. Cuando Ottalagano abandonó la UBA, Ivanissevich estuvo a cargo del Ministerio de Educación hasta ser reemplazado en agosto de 1975 por Pedro Arrighi. La designación y el protagonismo de ambos deben ser entendidos en el contexto más amplio de una escalada de violencia política legal e ilegal, donde la supuesta lucha contra la subversión inauguró el terrorismo de Estado antes de la última dictadura militar.

\section{VI - DEL AUGE AL OCASO}

Entre el 29 de mayo de 1973 y el 17 de septiembre de 1974 se sucedieron cuatro rectores en la rebautizada "Universidad Nacional y Popular de Buenos Aires": Puiggrós, Villanueva, Solano Lima y Laguzzi. Esa rápida sucesión de funcionarios de primera línea en tan sólo quince meses habla del grado de inestabilidad política que atravesó la institución, en un contexto nacional signado por los fuertes conflictos internos de la fuerza política gobernante: el movimiento peronista. En este marco, pueden delimitarse dos etapas para caracterizar las particularidades que adquirió el proceso de peronización de estudiantes, docentes e intelectuales porteños en ese momento conflictivo de la historia reciente argentina.

La primera comprende el lapso temporal entre la asunción de Puiggrós como interventor bajo el gobierno de Cámpora y las elecciones estudiantiles que concluyeron a fines del 1973, con Perón nuevamente como primer mandatario. Durante esos meses, la peronización adquirió un auge inédito. La gestión de la UNPBA hegemonizada por la izquierda peronista logró un respaldo masivo entre la población universitaria e incluso concitó importantes adhesiones de radicales y comunistas. La JUP tuvo un papel clave en este proceso, ya que canalizó esos apoyos y articuló políticas con otros sectores del estudiantado no peronista. La organización liderada por Ventura adquirió tal presencia y nivel de movilización que incluso se convirtió en garante de estabilidad de la gestión de Puiggrós,

\footnotetext{
${ }^{597}$ Izaguirre, I., "La Universidad y el Estado terrorista. La Misión Ivanissevich”, en Conflicto Social, No 5, 2011. 598 “Talento y Ventura fueron alojados en Villa Devoto", en La Opinión, 23 de noviembre 1974.
} 
frente a los primeros focos opositores que congregó. Además, cuando se le imposibilitó continuar en su cargo, las protestas que encabezó la JUP permitieron que los primeros puestos de la casa de estudio siguieran siendo ocupados por docentes vinculados a la izquierda peronista.

En este proceso de auge de la peronización que encabezó la JUP existieron claros y oscuros. Entre los primeros, es relevante resaltar lo fructífero que resultó su decisión de participar en los centros de estudiantes y la federación porteña, dejando atrás viejos prejuicios del peronismo universitario que identificaban a esos espacios como un simple reducto de "reformistas gorilas". La opción por intervenir en ámbitos propios de organización del estudiantado, desde un discurso que llamaba a dejar atrás la vieja dicotomía entre la CGU y la FUA, le permitió a la JUP canalizar una gran adhesión y compartir alianzas políticas con otras fuerzas. Por otra parte, entre los problemas que atravesó la organización de Ventura, debe señalarse la existencia de una tensión en su politización que generó grandes conflictos imposibles de resolver. Como vimos, la JUP buscaba atender las especificidades del estudiantado en el marco de dos referencias políticas: el gobierno peronista, al que pretendía aportarle políticas universitarias, y Montoneros, con el que seguiría el camino de la "guerra popular y prolongada". Cuando sus dos referentes entraron en conflicto, su posición en la UNPBA se hizo muy difícil de sostener. La JUP terminó adoptando un discurso enrevesado en el que pretendía mostrarse como parte del gobierno, cuando en realidad estaba resistiendo a esa misma instancia para que no desplace a la izquierda peronista de la intervención de la casa de estudio.

La segunda etapa para analizar las particularidades de la peronización de estudiantes, docentes e intelectuales puede delimitarse entre la sanción de la Ley Taiana en marzo de 1974 y la designación de Ottalagano como interventor en septiembre de ese mismo año. Con la llegada de la derecha peronista dejó de llamarse a la casa de estudio porteña "Universidad Nacional y Popular de Buenos Aires". Aunque el quiebre fundamental que inició el ocaso de la peronización comenzó con la Ley Taiana. La sanción de la normativa fue sumamente controvertida porque, por un lado, reconoció demandas de la izquierda peronista en torno a cómo organizar la universidad e incluso aceptó la propuesta del radicalismo para que los rectores fueran elegidos por la misma comunidad académica. Pero, por otro lado, terminó otorgando herramientas legales para combatir al activismo político universitario y creando un terreno fértil para el fortalecimiento de los sectores más reaccionarios y represivos.

Escudándose en los artículos $5^{\circ}$ y $51^{\circ}$ de la ley universitaria, Ivanissevich y Ottalagano desplazaron a las autoridades vinculadas a la Tendencia e iniciaron la represión del 
movimiento estudiantil. Resulta llamativo que el último intento de resistencia de Laguzzi, Villanueva, la JUP y ADUP fuera la convocatoria a un plebiscito para que la propia comunidad académica decidiera si debían seguir gestionando la UNPBA. Como vimos a lo largo de este trabajo, la izquierda peronista siempre reivindicó que la universidad no debía convertirse en una "isla ajena al país", por eso proponía un esquema organizativo que fuera capaz de articular la participación política de los claustros con la intervención del Estado en la planificación de las políticas universitarias. Lo paradójico, como bien marca Adriana Puiggrós en un texto escrito en el exilio, fue que el creciente enfrentamiento con el gobierno peronista la llevó a reivindicar de hecho una defensa extrema de la autonomía universitaria frente al Estado ${ }^{599}$.

\footnotetext{
${ }^{599}$ Puiggrós, A., "La universidad argentina de 1973-1974", en Controversia, № 1, octubre 1979; "La universidad de 1973-1974", Controversia, $\mathrm{N}^{\circ}$ 2-3, diciembre 1979. Estos artículos fueron posteriormente publicados en: Puiggrós, A., "Nacionalismo popular y universidad en la Argentina de 1973-74", en Democracia y autoritarismo en la pedagogía argentina y latinoamericana, Bs. As., Galerna, 1991. La revista Controversia fue editada por intelectuales peronistas y de izquierda en el exilio mexicano. En ella iniciaron un debate autocrítico sobre los sesenta y setenta. Su consejo de redacción estuvo integrado por José Aricó, Sergio Bufano, Rubén Sergio Caletti, Nicolás Casullo, Ricardo Nudelman, Juan Carlos Portantiero, Héctor Schmucler, Oscar Terán y Carlos Abalo.
} 


\section{CONCLUSIONES}

\section{UN NUEVO PERONISMO UNIVERSITARIO}

A lo largo de esta tesis intentamos contribuir al análisis de la politización de las universidades en los años sesenta y setenta desde los estudios de la nueva izquierda argentina. Si bien en el transcurso del siglo XX las casas de estudio ocuparon un papel preponderante en las disputas político nacionales y a la vez resultaron atravesadas por ellas, en aquel período de la historia reciente la dinámica política adquirió un matiz especial. A fines de los sesenta, numerosos universitarios participaron en la constitución de un heterogéneo conglomerado de fuerzas sociales y políticas que vinculó su oposición a la dictadura militar con la posibilidad de introducir cambios más amplios, representados en la idea de revolución, socialismo y liberación. La peronización de estudiantes, docentes e intelectuales de la UBA puede verse como un capítulo particular de la formación de la nueva izquierda en los sesenta y setenta.

Lo tratado en los cinco capítulos precedentes nos muestra que, más que un proceso general, lo que abordamos fue un estilo de peronización que llevó al surgimiento de un nuevo peronismo universitario. Esta experiencia implicó un fenómeno doble. Por un lado, fue un complejo camino a través del cual estudiantes, docentes e intelectuales procedentes de sectores que habían sido opositores al peronismo optaron por asumirlo como su propia identidad política, aunque desde una perspectiva revolucionaria acorde a los relatos de la época. Por otra parte, significó un itinerario que tejió otra forma de pensar el papel de la universidad para intentar superar viejos desencuentros y legitimar la nueva presencia del peronismo en las casas de estudio.

Esta primera aproximación requiere, sin embargo, otra aclaración producto del trabajo realizado. Al estudiar la peronización porteña reafirmamos la necesidad de no concebir de manera abstracta o general los procesos de politización y radicalización. Además, es indispensable dejar de pensar esas experiencias desde un recorrido lineal e ineluctable. Como ya ha señalado Oscar Terán, uno de los grandes riesgos que acechan al investigador es la tentación de explicar todo en clave teleológica y adjudicar finalidades desde la tranquilidad 
que nos da saber la evolución de los acontecimientos ${ }^{600}$. El análisis de las tramas discursivas y organizativas del "pasaje al peronismo de izquierda" nos permitió rescatar el carácter procesual de un trayecto que no fue lineal, en tanto involucró a un sinfín de actores y atravesó distintas coyunturas político-académicas entre mediados de la década del sesenta y principios de la siguiente.

En relación al plano organizativo esto quedó de manifiesto al reconstruir los sectores estudiantiles, docentes e intelectuales que se identificaron con el peronismo en esos años. Como vimos, no hubo un pasaje directo de los primeros agrupamientos peronizados como el FEN, UNE y las CN a la JUP y ADUP. Por el contrario, el surgimiento de unos y otros corresponde a dos etapas distintas del período delimitado. Entre 1966 y 1972 se fue modificando el panorama del peronismo en la UBA, luego de sus antiguos intentos infructuosos de generar apoyos en el estudiantado. Tras las fallidas experiencias de la CGU, los ANDE y la primera JUP, surgió al poco tiempo de la intervención universitaria de Onganía un conjunto de organizaciones estudiantiles que se declararon "nacionales" o directamente "peronistas". La reconstrucción de la trayectoria de sus principales referentes e integrantes nos permitió visualizar que buena parte de ellos provenían de sectores reformistas y, sobre todo, de núcleos católicos posconciliares que antes del golpe de 1966 habían abandonado sus posturas antiperonistas e incluso acompañaron activamente a la CGT en su Plan de Lucha de 1964. En este punto, si bien es legítimo rotular a la intervención de Onganía como un "catalizador" de la peronización, ya que situó a los universitarios y al peronismo en un mismo plano de proscripción política, no debe perderse de vista que anteriormente se venían desarrollando articulaciones entre esos dos actores.

El pasaje al peronismo de estos primeros núcleos universitarios contenía un rasgo específico. Ellos no pedían volver a los primeros gobiernos de Perón, ni crear la comunidad organizada. Su idea de ser "nacionales" o de ser "peronistas" estaba íntimamente ligada a ser antiimperialistas y socialistas. Desde ya que el ideario de un nacionalismo revolucionario anclado en los conceptos de liberación nacional y social no era nuevo. Antes de 1966 existían expresiones universitarias de izquierda e incluso católicas donde esas ideas eran recurrentes. Pero lo particular de grupos como el FEN, UNE, JAEN, CENAP y otros fue que tramitaron esa nacionalización mediante su peronización. A su entender, el movimiento liderado por Perón era la única opción política que podía concretar esos horizontes tercermundistas y revolucionarios. En esta cuestión fueron referencias las producciones de intelectuales como Cooke, Hernández Arregui y Puiggrós. No obstante, las CN jugaron un papel importante dado

\footnotetext{
${ }^{600}$ Terán, O., "Pensar el pasado", en Punto de Vista, № 58, agosto 1997.
} 
que generaron nuevos aportes político-intelectuales para argumentar esas posiciones desde las mismas aulas de la UBA. A esto se sumaba que varios de los jóvenes docentes e intelectuales que integraron las $\mathrm{CN}$, procedían de los mismos núcleos militantes que habían confluido en la formación de los grupos estudiantiles peronistas, lo que posibilitaba en cierta medida una relación cotidiana y "cara a cara".

Sin embargo, una de las principales cuestiones escasamente estudiadas que destacamos al analizar las tramas organizativas fue el papel clave de la CGTA en la peronización porteña. La central que encabezó Raimundo Ongaro ofreció un espacio concreto para que los universitarios converjan con sectores de la clase obrera en la oposición a la dictadura de Onganía, a partir de un programa que mixturaba peronismo, cristianismo posconciliar y medidas con tintes anticapitalistas. De ese modo, la CGTA terminó cumpliendo una función de enlace entre los distintos grupos peronizados, al coordinar acciones conjuntas con ellos e incluso con la FUA, a medida que crecía el frente opositor a la dictadura en 1968 y sobre todo al año siguiente con el Cordobazo. Este no es un tema de poca importancia si tenemos en cuenta que las organizaciones estudiantiles peronistas estaban fuertemente fragmentadas y las $\mathrm{CN}$ eran una experiencia anclada en Filosofía y Letras. El surgimiento de grupos como el FEN, UNE, CENAP, JAEN, CEP y las CN si bien cambió la situación del peronismo en relación a los viejos tiempos, estuvo lejos de convertirlo en hegemónico en la UBA. De todos los grupos que nombramos, el que más peso y visibilidad tuvo en ese momento fue el FEN; aunque en su disputa con la FUA intentó crear una entidad política más amplia que aglutinara a los "sectores nacionales", no logró alcanzar ese objetivo y finalmente la que cumplió el papel de enlace fue la central de Ongaro.

Justamente el FEN, el grupo más importante de "pasaje al peronismo" a fines de los sesenta, no fue el protagonista principal de la nueva etapa abierta entre 1972 y 1973, la cual estuvo signada por la retirada de la dictadura y el retorno del peronismo al gobierno. Al indagar en las tramas organizativas, pudimos reconstruir dos procesos que han sido escasamente estudiados y fueron centrales a la hora de canalizar la peronización de universitarios porteños a principios de esa década. Los dos empezaron a desarrollarse en 1972 y terminaron de plasmarse en 1973.

El primero fue el pasaje de la CUP a la JUP. Como vimos, esta última organización no surgió espontáneamente en abril de 1973 luego del triunfo de Cámpora. Al contrario, sus raíces estaban vinculadas a una experiencia que comenzó a gestarse un tiempo antes. Hacemos referencia a la unificación de los distintos agrupamientos juveniles que impulsó el mismo Perón y en la que tampoco estuvo ausente Montoneros, a través de su articulación con 
Galimberti, el representante de la JP en el Consejo Superior del MNJ. Si bien no pudo materializarse una unidad completa de los distintos grupos, estas rearticulaciones permitieron el surgimiento de la JP Regionales, de la cual a su vez se desprendieron frentes de masas particulares, entre ellos la JUP. Todo este sector funcionaba en un esquema organizacional bajo la conducción de Montoneros, más allá de que sus militantes no estuvieran necesariamente encuadrados en la estructura armada.

Sin embargo, en el caso particular de la JUP, uno de los espacios de la JP Regionales más activos y movilizados, no puede sostenerse que su surgimiento sólo dependió de un proceso operado de arriba hacia abajo. Desde una mirada retrospectiva, la JUP también logró materializarse porque tenía tras de sí una nueva militancia universitaria peronista que había comenzado a gestarse a fines de los sesenta y revitalizado sus lazos a inicios de la década siguiente, acompañando la irrupción de los cuerpos de delgados en la UBA. Este sustrato militante previo fue el que permitió el surgimiento de la CUP en 1972, a raíz de la articulación entre los CEP, CENAP, FANDEP y las Bases Peronistas. Aunque esta coordinadora tampoco habría podido dar un salto de unidad más amplio si no hubiese existido la JP Regionales y Montoneros. Salvando las distancias, estos últimos en cierto sentido cumplieron un papel parecido a la CGTA en años anteriores, al ofrecer un espacio concreto en el que pudieron confluir y fortalecerse los activistas universitarios. De esta manera, a la JUP se sumó el núcleo de la CUP, pero también formaron parte de ella grupos como FORPE, AEP, entre otros.

El segundo proceso que indagamos para entender las experiencias de peronización a inicios de los setenta, fue el surgimiento de cuatro agrupamientos que en buena medida encauzaron la actividad política y/o profesional de los universitarios porteños: la ADUP, los EPT, el CT y la AAP. La primera era la equivalente de la JUP en el ámbito docente. Los otros dos se generaron específicamente para formar cuadros y políticas de gobierno, mientras que la última era un espacio de abogados enfocado en la defensa de presos políticos. De todos ellos, sólo ADUP y los EPT estaban referenciados a la JP Regionales y Montoneros, el resto se enmarcaba en el campo más amplio de la Tendencia Revolucionaria. De estos espacios, surgieron los principales funcionarios que designó Puiggrós para cubrir cargos de gestión en el rectorado y las facultades de la UBA, una vez que asumió el 30 de mayo de 1973 como nuevo interventor. En este punto, su designación puede entenderse como un reconocimiento a toda una franja de la izquierda peronista que había podido construir una fuerte base organizativa y de apoyo en el mundo universitario.

La reconstrucción de la dimensión discursiva de la peronización de estudiantes, 
docentes e intelectuales fue otro de los aportes importantes de esta tesis. Como vimos, los grupos que se orientaron hacia el peronismo de izquierda en aquel entonces otorgaron cada vez mayor centralidad a la política, pero también se vieron obligados a buscar nuevos relatos para la universidad. Esto era una problemática ineludible y difícil de soslayar. El peronismo tenía una historia conflictiva tras de sí con el espacio académico. En los años cuarenta y cincuenta, buena parte de sus opositores más activos había surgido en ese ámbito. Por eso, los universitarios peronizados no sólo tenían que buscar elementos para explicar su nueva pertenencia política, sino también para justificar su presencia en las casas de estudio y sus intenciones de transformarlas.

Los discursos que analizamos en relación a la cuestión universitaria carecieron de linealidad y tuvieron un carácter zigzagueante. El itinerario que va desde Antropología 3er. Mundo hasta Envido no implicó un discurso monocorde y atravesó distintas experiencias. Pueden diferenciarse tres momentos de discusión entre 1966 y 1973. El primero fue a fines de los sesenta y se reflejó en los primeros números de la revista Antropología 3er. Mundo. En ese momento, la publicación y el espacio de las $\mathrm{CN}$ se hicieron eco de una controversia más amplia que venía afrontando el campo político-intelectual vinculado a la nueva izquierda en años anteriores. Ésta no era otra que la clásica querella sobre el peronismo y las clases medias. De esta manera, se fue esbozando un incipiente discurso que sostenía que para lograr una alianza efectiva entre estos dos polos había que partir de las especificidades organizativas e ideológicas del mundo universitario. Ya no se podía continuar con la vieja metodología de la primera JUP y los ANDE, creyendo que la solución a ese conflicto sólo consistía en acercar a los estudiantes a las protestas de los trabajadores. Todo lo contrario, ahora había que prestar más atención a la situación particular de las casas de estudio y proponer políticas adecuadas.

Si bien ni Antropología 3er. Mundo ni las CN llegaron a plantear un nuevo proyecto de universidad, abrieron una incipiente autocrítica en el papel del peronismo universitario que también se manifestaba cuando hacían alusión a los primeros gobiernos de Perón. De éstos más que nada rescataban su importancia en la democratización social de las casas de estudio. Pero a la hora de pensar su rol político en la universidad, recurrieron a FORJA y ahí se encontraron con la Reforma de 1918 y el Manifiesto Liminar, o por lo menos con una de sus demandas centrales. Para el peronismo de izquierda era imperioso reconocer que la participación política plena del estudiantado garantizaba una presencia crítica que era capaz de articular la problemática académica con confrontaciones sociales más amplias. Por esta razón, no negaba la Reforma, sino que cuestionaba a quienes supuestamente la habían desnaturalizado y encerrado en demandas puramente académicas. 
El segundo momento de debate de la cuestión universitaria se produjo a principios de los setenta cuando se desarticularon las $\mathrm{CN}$ e irrumpieron los cuerpos de delgados en el movimiento estudiantil de la UBA, en un contexto signado por grandes protestas sociales, el accionar de las organizaciones armadas y los recambios presidenciales en el gobierno militar. Entre 1971 y 1972 se puso en primer plano un discurso fuertemente radicalizado que cuestionó las estructuras políticas y pedagógicas "tradicionales" de la universidad. El mismo podía rastrearse en espacios peronistas y de izquierda, como en las revistas Antropología 3er. Mundo, Los Libros y grupos estudiantiles como CEP, CENAP y FAUDI. A diferencia de la etapa anterior, ahora las voces militantes directamente daban por muerta a la Reforma. La participación política del estudiantado era puesta en primer lugar, incluso con exigencias de que los docentes se subordinaran a ella; aunque su anclaje no estaba en las "caducas" formas liberales de representación, encarnadas en los centros, las federaciones y el gobierno tripartito. Las críticas a estos ámbitos no eran novedosas, en el caso del peronismo se podían encontrar en años anteriores, pero lo que sí era innovador era esa pretensión de querer refundar la universidad "desde las bases", expresadas en los cuerpos de delegados y las asambleas estudiantiles. Dichas instancias eran consideradas un lugar privilegiado para instaurar una línea de confrontación con la dictadura, pero también para debatir cómo estaban organizados los planes de estudio, las materias y las metodologías de evaluación. Sin embargo, estas propuestas no duraron demasiado y se fueron desarticulando en 1972, a medida que el comunismo triunfaba en las elecciones de centros de estudiantes.

El tercer momento de discusión de la cuestión universitaria tuvo lugar en 1973, en el lapso comprendido entre la victoria electoral del FREJULI en marzo y la asunción de Cámpora a fines de mayo. En ese escenario surgieron la JUP y ADUP, las cuales difundieron un discurso que por primera vez presentaba un decálogo de medidas concretas para transformar los fines y la estructura de las casas de estudio. Las propuestas para la nueva universidad de estas dos organizaciones fueron publicitadas en Envido y formaron parte de una red más amplia de revistas, diarios, libros y editoriales donde un conjunto de actores de diverso signo político diagnosticaban la crisis de la universidad argentina y sugerían distintas recetas para remediarla. En el caso de la JUP y ADUP, presentaron sus soluciones con el propósito de contribuir a la política universitaria del nuevo gobierno peronista y a la elaboración de una futura ley universitaria. Estas propuestas fueron reconocidas desde un primer momento y el propio Cámpora las hizo suyas en el mensaje que dirigió a la asamblea legislativa el mismo día de su asunción como presidente. Sobre todo al afirmar que la tarea de la universidad era acabar con la dependencia cultural y que era necesario superar las viejas 
antinomias como "reforma / anti-reforma" y "autonomía universitaria / dependencia de gestión”. Para la izquierda peronista, esto sólo sería posible si la universidad era capaz de mixturar en su gobierno la participación de todos sus componentes -estudiantes, docentes, no docentes- con mecanismos de representación de la comunidad e instancias orientadoras del Estado.

En este último punto radicó, a nuestro entender, la principal potencialidad del estilo de peronización que terminó gestando un nuevo peronismo universitario ¿Dónde radicaba lo nuevo? La novedad residía no sólo en su prédica a favor del socialismo nacional y la revolución, sino en su intento de superar viejos enfrentamientos y revisar distintos legados para proponer una política universitaria que fuera acorde a la realidad argentina de los setenta. Esta actitud fue la que le permitió a ese peronismo de izquierda iniciar una gestión en la UBA que recibió el visto bueno de agrupaciones reformistas y la que incluso posibilitó, en meses posteriores a la asunción de Cámpora y Puiggrós, que la JUP se presentara a elecciones de centros de estudiantes y participara en la disputa por la conducción de la FUBA, federación que en otros tiempos había sido uno de los símbolos del reformismo y el antiperonismo.

Si consideramos en conjunto las tramas organizativas y discursivas, podemos destacar como último aporte de esta tesis que la politización y la partidización de la JUP y ADUP condujeron a una tensión irresoluble en el transcurso del último gobierno peronista; especialmente cuando se produjo el desencuentro entre el líder retornado del exilio y los sectores del movimiento que habían vinculado la oposición a la dictadura militar con la posibilidad de impulsar transformaciones más profundas. Como vimos, ambas agrupaciones pretendían atender las especificidades de las casas de estudio en el marco de dos referencias políticas: el gobierno peronista, al que procuraban aportarle políticas universitarias, y Montoneros, con el que seguirían el camino de la "guerra popular y prolongada". Cuando sus dos referentes entraron en conflicto, la JUP y ADUP terminaron descolocadas en su accionar político-universitario, debido a que ese mismo gobierno que decían defender instrumentó desde fines de 1973 distintas medidas para desplazar a sus funcionarios afines de la intervención de la UBA. A su vez, la misma política de distanciamiento de Montoneros respecto a Perón produjo escisiones al interior de la JP Regionales que se replicaron en el frente universitario con el surgimiento de JUP y ADUP Lealtad. A esto se sumó que la ley universitaria que habían discutido desde un principio con tanta expectativa, finalmente se aprobó en 1974 con dos artículos controvertidos que permitieron que la UBA fuera nuevamente intervenida, esta vez bajo sectores de la derecha peronista. De esta manera, durante el gobierno de Isabel Perón se implementó una concepción contraria a la de la 
izquierda peronista, sobre todo en relación al papel político del estudiante en la universidad. Mientras esta última lo consideraba una correa de trasmisión para vincular la problemática académica con cuestiones revolucionarias más amplias, la derecha peronista lo imaginaba como un foco infeccioso que promovía la subversión.

A lo largo de esta investigación analizamos los cruces entre política y universidad en la historia reciente de nuestro país. Desde este lugar, reconstruimos trayectorias de estudiantes, docentes e intelectuales para vislumbrar un proceso de múltiples afluentes político-ideológicos que incidieron en la conformación de un conjunto de agrupamientos referenciados con el peronismo de izquierda. Estos fueron reconfigurando y dinamizando sus tramas organizativas y discursivas en un contexto conflictivo en el plano político y cultural. Un tema central radicó en cómo estos grupos elaboraron un proyecto de universidad desde el cual incidieron en la gestión de la UBA en 1973 y en la sanción de la ley universitaria de 1974; concibiendo a la casa de estudio y a la legislación como la expresión de un conjunto de luchas entre en una pluralidad de articulaciones sociales que involucraban actores, representaciones y coyunturas de diversa índole.

A modo de cierre, señalamos algunas problemáticas pendientes que pueden profundizar investigaciones futuras para mostrar nuevas aristas del caso estudiado. Si bien en esta tesis reconstruimos el respaldo de la JUP y ADUP a la gestión de Puiggrós, todavía resta un análisis más pormenorizado sobre cómo se desarrolló esta experiencia en cada una de las facultades porteñas, haciendo hincapié en la trayectoria y la perspectiva político-académica de los integrantes de cada institución. Asimismo, nos parece necesario seguir fortaleciendo el estudio sobre la cuestión universitaria en el amplio conglomerado de la nueva izquierda argentina en los años setenta. El análisis de grupos escasamente explorados como el Movimiento de Orientación Reformista o la Juventud Radical Revolucionaria, puede contribuir a mostrar distintas facetas de la partidización de un heterogéneo conglomerado de sectores docentes y estudiantiles que no se reducía al peronismo. En este marco, nuestro principal aporte radicó en vislumbrar que la JUP y ADUP propusieron un proyecto complejo que articulaba medidas del primer peronismo -la gratuidad y la planificación estatal- con conquistas de la Reforma -participación política del estudiantado y cogobierno-, el cual incluso interpeló a núcleos radicales y de izquierda. En definitiva, esperamos haber mostrado que hasta en los momentos más álgidos de la política no se disolvió completamente la cuestión universitaria. 


\section{NOTAS AMPLIATORIAS}

\section{I - LA REFORMA UNIVERSITARIA DE 1918}

La Reforma Universitaria se originó en Córdoba. Una huelga prolongada de estudiantes y graduados recientes trastocó la organización y el gobierno de la universidad mediterránea en $1918^{601}$. El proceso no sólo repercutió en la casa de estudio más antigua y tradicional del territorio rioplatense, ya que sus resonancias llegaron rápidamente a los claustros de Buenos Aires, La Plata, Santa Fe y Tucumán ${ }^{602}$. Pero a pesar de sus distintas ramificaciones, no caben dudas que el primer acontecimiento fue decisivo y fundamental. La transformación de todas las universidades del país estuvo directamente relacionada a las demandas que enarboló el movimiento reformista en los momentos más álgidos del conflicto cordobés $^{603}$. Éste transcurrió entre la huelga general de estudiantes que desató la suspensión del Internado del Hospital Nacional de Clínicas a principios de 1918 y la reforma estatutaria que decretó Hipólito Yrigoyen el 7 de octubre de ese mismo año. Sin embargo, la etapa decisiva fue cuando los reformistas plasmaron sus reclamos más importantes en el Manifiesto Liminar que redactó Deodoro Roca y en el Primer Congreso Nacional de Estudiantes Universitarios celebrado en la misma ciudad mediterránea entre el 20 y 31 de julio de 1918.

Tres meses antes de este último encuentro, la federación estudiantil cordobesa había publicado por primera vez la Gaceta Universitaria. Dicho órgano de prensa fue el vocero oficial del movimiento de protesta y al poco tiempo de su publicación pasó a la historia con la edición del documento fundacional de la Reforma. El Manifiesto Liminar llamaba a una nueva hora americana encabezada por las jóvenes generaciones y proclamaba la ruptura de la última cadena de dominación monárquica y monástica que pervivía en pleno siglo $\mathrm{XX}^{604}$. Pero en lo estrictamente universitario, sus propuestas eran muy claras y acotadas. El principal

\footnotetext{
${ }^{601}$ Buchbinder, P., ¿Revolución en los claustros? La Reforma Universitaria de 1918, Bs. As., Sudamericana, 2008, pp. 10-11.

${ }^{602}$ En ese entonces, existían cinco universidades en la Argentina. Las tres primeras eran nacionales y las últimas dos provinciales. Investigaciones como las de Graciano, Caldelari y Funes señalan cómo las movilizaciones estudiantiles en las tres universidades nacionales adquirieron rasgos específicos en cada una de ellas. Graciano, O., Entre la torre de marfil y el compromiso político. Intelectuales de izquierda en la Argentina 1918-1955, Bernal, UNQUI, 2008; Caldelari, M., y Funes, P., Escenas reformistas. La Reforma Universitaria 1918-1930, Bs. As., Eudeba, 1998.

${ }^{603}$ Compartimos con Portantiero que el reformismo fue un movimiento de clases medias que construyó sus demandas y sus clivajes político-ideológicos a medida que avanzaban los acontecimientos. Portantiero, J. C., Estudiantes y política en América Latina. El proceso de la Reforma Universitaria, México, Siglo XXI, 1987.

${ }^{604}$ Como dijimos, el Manifiesto Liminar fue publicado el 21 de junio de 1918. Lo firmaron los integrantes de la mesa directiva de la FUC, pero fue íntegramente redactado por Deodoro Roca. Se dice que elaboró el contenido de la segunda parte con la colaboración de Emilio Biagosch. Ciria, A., y Sanguinetti, H., La Reforma Universitaria / 1, Bs. As., CEAL, 1983, p. 49.
} 
reclamo de la proclama reformista hacía hincapié en la participación estudiantil en el gobierno de las casas de estudio. Para la FUC, sólo era posible crear una institución democrática, científica y moderna, si la soberanía de la universidad radicaba principalmente en los estudiantes $^{605}$. Esta postura caldeó aún más el conflicto, aunque no está demás aclarar que no era la primera vez que se discutía en el ámbito político y académico. En 1908, el Primer Congreso de Estudiantes Americanos reunido en Montevideo ya había exigido púbicamente el derecho a participar en los órganos de gobierno ${ }^{606}$. Y hasta la misma Federación Universitaria de Buenos Aires (FUBA) debatió el tema en el parlamento nacional en $1917^{607}$.

El reclamo por la representación estudiantil fue muy importante en el conflicto cordobés del año siguiente, aunque no se impuso directamente entre el repertorio de sus peticiones irrenunciables. No olvidemos que en un primer momento, el movimiento reformista había aceptado los cambios del primer interventor que designó el gobierno radical para solucionar las controversias el 11 de abril de 1918. La reforma de José Nicolás Matienzo, en ese entonces Procurador General de la Nación y catedrático de la casa de estudio platense y porteña, acababa con el régimen de las academias vitalicias y ponía al gobierno de la universidad bajo el control del cuerpo de profesores. A pesar de todo, el nuevo proceso electoral que surgió de estos cambios terminó eligiendo como nuevo rector a Antonio Nores, el representante de los viejos sectores conservadores encabezados por la Corda Frates, y no a Martínez Paz, el candidato del reformismo ${ }^{608}$. Los mismos estudiantes que en un primer momento habían aceptado la elección del 15 de junio, terminaron interrumpiendo la Asamblea Universitaria y declarando una nueva huelga. Por esta razón, cinco días más tarde, el Manifiesto Liminar denunciaba la "reforma Matienzo" y el predominio de la casta de profesores como antidemocráticos e incapaces de impulsar el verdadero cambio que

\footnotetext{
605 "La juventud universitaria de Córdoba a los hombres libres de Sudamérica: Manifiesto Liminar", en 19181998 La Reforma Universitaria, Bs. As., Editorial La Página, 1998, p. 12.

${ }^{606}$ El mismo transcurrió entre el 26 de enero y el 2 de febrero de 1909 y contó con delegaciones de ocho naciones americanas: Argentina, Bolivia, Brasil, Cuba, Chile, Paraguay, Perú y Uruguay. El encuentro tuvo una repercusión inmediata en el país anfitrión. El 31 de diciembre de ese mismo año, el Congreso Nacional uruguayo aprobó una ley orgánica universitaria que reconocía un consejero estudiantil. Del Mazo, G., Estudiantes y gobierno universitario, Bs. As., El Ateneo Editorial, 1955, pp. 25-26. Éste trabajo no puede pasarse por alto, fue escrito por uno de los líderes de la Reforma y estudia cómo se consolidó la demanda de representación estudiantil en dicho movimiento.

${ }^{607}$ La FUBA fue fundada el mismo año del congreso estudiantil en Montevideo. Durante la década de 1910, algunos centros incluyeron a la representación estudiantil en el repertorio de sus reclamos. Buchbinder, P., Ob. cit., 2008, p. 64.

${ }^{608}$ El diario La Nación ofrecía una descripción pintoresca del sector que promocionaba la elección de Nores: "¿Qué es la Corda? No es partido ni un club ni una sociedad ni nada que se le parezca. Es una tertulia de doce caballeros, católicos... Universitarios en su mayoría, políticos casi todos, funcionarios y ex funcionarios, legisladores y ex legisladores... Tiene gente de todos los partidos. Así que caiga quién caiga, triunfe quién triunfe, la Corda sale siempre parada", en La Nación, 18 de junio 1918, p. 6.
} 
necesitaba la enseñanza superior ${ }^{609}$.

El mismo día que Yrigoyen había firmado el decreto de intervención del 11 de abril de 1918, los estudiantes reformistas fundaron la Federación Universitaria Argentina (FUA), con el propósito de otorgar mayor fuerza a sus reivindicaciones. El acta constitutiva asentaba la necesidad de lograr la representación política en los consejos directivos y un encuentro nacional de estudiantes ${ }^{610}$. Como vimos anteriormente, la primera reivindicación se puso en suspenso durante el desarrollo de la intervención Matienzo, pero volvió a primer plano cuando fracasó la misma y un mes más tarde sesionó el Primer Congreso Nacional de Estudiantes en medio de la protesta cordobesa. Éste contó con la participación de delegaciones de Santa Fe, Tucumán, Buenos Aires y La Plata, y terminó de sistematizar las dos demandas centrales que reclamaba el movimiento reformista: la participación estudiantil en los órganos de gobierno y la libertad de cátedra. Las mismas quedaron de manifiesto en el Proyecto de Ley Universitaria que emanó de las deliberaciones del encuentro ${ }^{611}$. La propuesta establecía consejos tripartitos con participación de profesores, diplomados y estudiantes. A su vez, reconocía la figura del profesor libre con plenos derechos electorales en el cuerpo docente. La libertad de enseñanza era asociada a la de aprendizaje, ya que no era considerada obligatoria la asistencia de los alumnos a las clases de los docentes universitarios y podían optar por cursos paralelos a los oficiales para aprobar la materia. Pero a pesar de las nuevas demandas que incorporaba, el esbozo legislativo estudiantil no se apartaba de los lineamientos esenciales de la antigua Ley Avellaneda de 1885. Seguía reservando en el poder ejecutivo la aprobación de los estatutos universitarios y la designación final de los profesores titulares, a partir de una terna elaborada por los consejos directivos de las facultades ${ }^{612}$.

Las protestas en la ciudad mediterránea llegaron a su fin con la llegada del Ministro de Justicia e Instrucción Pública del gobierno de Yrigoyen. Esta nueva intervención encabezada por José Salinas no se concretó rápidamente y recién arribó a Córdoba el 12 de septiembre de 1918, un mes más tarde de la renuncia de Nores al rectorado y unos cuantos días después de

\footnotetext{
609 "La juventud universitaria de Córdoba a los hombres libres de Sudamérica: Manifiesto Liminar", en 1918 1998 La Reforma Universitaria, Bs.As., Editorial La Página, 1998, pp. 12-13.

${ }^{610}$ Finocchiaro, A., El mito reformista, Bs. As., Eudeba, 2014, p. 131.

611 "Proyecto de Ley Universitaria y bases estatutarias (1918)", en Ciria, A., y Sanguinetti, H., Ob. cit., 1983, pp. 59-63.

${ }^{612}$ La ley 1597 otorgaba a las universidades la capacidad de dictar sus estatutos, pero estos debían subordinarse a las reglas de la ley y someterse a la aprobación final del poder ejecutivo. Esta cláusula del artículo 21, con excepción del periodo 1955-66, perduró en los siguientes ordenamientos legales, aunque la actual ley 24.521 limita dicha revisión al examen de su conformidad con las normas superiores y somete la decisión final en caso de controversia al Poder Judicial. Mignone, E., Política y universidad. El estado legislador, Bs. As., Lugar Editorial, 1998, p. 20
} 
su designación ${ }^{613}$. Después de un tiempo prudente de normalización, el mismo Salinas dispuso otra modificación de los estatutos de la universidad para el 5 de octubre. Esta medida cerró el ciclo de protesta que venía sosteniendo el movimiento reformista desde la suspensión del Internado del Hospital de Clínicas y materializó las demandas más importantes del Manifiesto Liminar y del Primer Congreso Nacional de Estudiantes. El nuevo ordenamiento introdujo la representación estudiantil en el gobierno universitario y el régimen de docencia libre, aunque vale aclarar que estos cambios pudieron llevarse adelante sin necesidad de modificar el ambiguo articulado de la Ley Avellaneda y terminaron extendiéndose a todas las casas de estudio del país ${ }^{614}$. En perspectiva y desde una mirada retrospectiva, la Reforma Universitaria puede ser leída metafóricamente con la imagen de la revolución permanente que propuso León Trotsky en 1929. La gesta iniciada en córdoba desterró dos modelos de gestión universitaria en un mismo movimiento. Uno era el régimen de las academias vitalicias de la ciudad mediterránea. El otro era el gobierno de profesores que regía en Buenos Aires, La Plata y dificultosamente en la misma Córdoba desde la primera reforma de Matienzo hasta la última intervención de Salinas.

En sus orígenes, el movimiento reformista centró sus demandas en la representación estudiantil y la libertad de cátedra, con la finalidad de construir una universidad moderna y científica $^{615}$. Es necesario volver aclarar el asunto porque en la actualidad muchos otorgan a la Reforma principios y consignas que no estaban entre las reivindicaciones más importantes de 1918, como la autonomía y el ingreso gratuito e irrestricto a la enseñanza superior. La primera es llamativa si se tiene en cuenta que en el Manifiesto Liminar y en el proyecto de ley universitaria del Primer Congreso Nacional de Estudiantes ni siquiera aparecía la palabra ${ }^{616}$. La autonomía no era una cuestión central de la agenda y eso lo demuestra que la propuesta más elaborada en relación a ese tema pasó sin pena ni gloria por las discusiones que tuvieron lugar en el encuentro de la FUA. Emilio Biagosch intentó introducir en la discusión un concepto de autonomía que implicaba la independencia económica de las casas de estudio y su capacidad para dictarse normas propias, en especial las relacionadas a las formas de gobierno, los planes de estudio, los métodos de enseñanza, los sistema de promoción, las

\footnotetext{
${ }^{613}$ El gobierno radical designó a Salinas el 23 de agosto de 1918, luego del fallido intento de imponer como interventor a Telémaco Susini por la fuerte oposición de los sectores más tradicionalistas. Finocchiaro, A., Ob. cit., 2014, p. 161.

${ }^{614}$ A pesar de este panorama general, no puede pasarse por alto que la expansión de la Reforma en otras universidades tuvo sus propias particularidades.

${ }^{615}$ Para Burchbinder, la Reforma produjo lo contrario de lo que pretendía. En vez de formar una universidad dedicada a la producción cultural y la investigación científica, terminó reafirmando el antiguo modelo profesionalista. Buchbinder, P., "El movimiento reformista de 1918", en Estudios Sociales, Santa Fe, N 19, 2000, pp. 37-63.

${ }^{616}$ Finocchiaro, A., Ob. cit., 2014, p. 145 y 154.
} 
cuestiones docentes y administrativas. Sin embargo, esta idea no quedó plasmada en el proyecto de ley que emanó del congreso, ya que la elección de los profesores titulares y la aprobación final de los estatutos continuaron otorgándose al poder ejecutivo ${ }^{617}$. Tampoco estaba entre las demandas relevantes de la Reforma el ingreso no arancelado e irrestricto a la universidad. El Primer Congreso Nacional de Estudiantes discutió esta consigna, pero no llegó aprobar el reclamo por la gratuidad total de la enseñanza superior. En los años siguientes, hasta los mismos centros de estudiantes enfrentaron el levantamiento de aranceles y de exámenes de ingreso debido a que era un poderoso mecanismo para controlar el acceso al título profesional ${ }^{618}$, aunque no está de más aclarar que los sectores más politizados del reformismo fueron incorporando y fortaleciendo esa demanda con el correr del tiempo, como manifiesta el acta fundacional de la Unión Latinoamericana que firmaron José Ingenieros, Julio V. González, Gabriel Del Mazo y el mismo Deodoro Roca el 21 de marzo de $1925^{619}$.

\section{II - EL IDEARIO REFORMISTA: ESA TENSIÓN IRRESOLUBLE ENTRE UNIVERSIDAD Y POLÍTICA}

A principios del siglo pasado, José Carlos Mariátegui reunió en un único libro sus Siete ensayos sobre la sociedad peruana. Ya habían sido publicados con anterioridad en las revistas Mundial y Amaúta, pero ahora veían la luz en forma conjunta y revisada. Uno de esos escritos demostraba los alcances continentales de la Reforma y cuestionaba las lecturas que pretendían reducirla a una experiencia exclusivamente universitaria ${ }^{620}$. No viene mal recordar la advertencia del antiguo reformista y fundador del Partido Socialista Peruano. En sus inicios, la Reforma tuvo una faz ideológica-política que no puede desatenderse de los grandes cambios que vivió el mundo, América Latina y Argentina al iniciarse el 1900. La Primera Guerra Mundial, el ascenso bolchevique al poder, la Revolución Mexicana y la irrupción del radicalismo modificaron el escenario político, social y cultural de esos años agitados. Sin embargo, no conviene sobredimensionar esa faceta. Durante sus primeros pasos, el movimiento reformista fue un reducto político de las clases medias sin clivajes ideológicos bien definidos. El mismo Manifiesto Liminar pivoteaba sobre un ideario marcado por el americanismo, el anticlericalismo, el romanticismo juvenil y el humanismo utópico. Pero nunca establecía ni ahondaba en una programática concreta y sistemática en lo estrictamente político.

\footnotetext{
${ }^{617}$ Ibídem, p. 150.

${ }^{618}$ Buchbinder, P., Ob. cit., 2008, p. 126 y 155.

619 "Acta de fundación de la Unión Latinoamericana", en Ciria, A., y Sanguinetti, H., Ob. cit., 1983, pp. 69-70.

${ }^{620}$ Mariátegui, J. C., Siete ensayos de interpretación de la realidad peruana, Bs. As., Prometeo, 2010 [1928], pp. 147-148.
} 
Esta indefinición estaba vinculada a una controversia sobre política y universidad que marcó a fuego los orígenes de la Reforma. La misma quedó de manifiesto en el Primer Congreso Nacional de Estudiantes de 1918. El movimiento estudiantil no era un actor homogéneo y estaba atravesado por dos posiciones que disputaban su hegemonía. La primera resultó mayoritaria y la encabezaba el presidente electo de la FUA. Osvaldo Loudet representaba una corriente apoliticista que pretendía mantenerse al margen de los partidos y de las problemáticas socio-políticas externas. En su discurso de apertura, convocaba a las almas de Sarmiento, Mitre y Alberdi, mientras sentenciaba que todo era ajeno al congreso, menos las cuestiones universitarias y científicas ${ }^{621}$. El otro sector agrupaba a dirigentes que tendrían una larga trayectoria política, como Gabriel Del Mazo, Julio V. González y Alejandro Korn. Para esta postura era inconcebible separar a la Reforma de trasformaciones sociales más amplias. En los sucesos de 1918, terminaron en inferioridad, pero a larga su lectura tuvo una influencia mayor en Argentina y el resto de Latinoamérica ${ }^{622}$. El mismo Del Mazo ocuparía más tarde la presidencia de la FUA y dirigentes de la talla de Mariátegui, Víctor Raúl Haya de la Torre y Julio Antonio Mella abonarían a la perspectiva de que "no hay reforma universitaria sin cambio social" ${ }^{623}$. Deodoro Roca fue quien mejor sintetizó esta perspectiva al cumplirse 18 años de los sucesos de Córdoba. En su periódico Flecha, convocó a meditar sobre los logros y los fracasos del movimiento reformista. Al contestar su propio cuestionario, sostuvo que la Reforma significaba enlace vital de lo universitario con lo político y que no pensar esto constituía en sí mismo una monstruosidad ${ }^{624}$.

La relación entre universidad y política es una controversia que tiene múltiples manifestaciones en la historia del movimiento reformista de nuestro país. Sin embargo, la Reforma no tiene un programa oficial, ya que nadie puede invocar el título de vocero exclusivo de sus principios políticos y académicos. Su repertorio "tradicional" de soluciones se arquitectó en el Manifiesto Liminar y en el Primer Congreso Nacional de Estudiantes de 1918, pero luego fue resignificado a través de debates, polémicas y observaciones. Los aspectos académicos e ideológicos de la Reforma se modificaron históricamente en función de coyunturas y debates que transitó el espacio político-universitario. De esta manera, adquirió la forma de una tradición mixta, de naturaleza política como cultural, con un claro

\footnotetext{
621 "Discurso del Presidente de la Federación Universitaria Argentina", en Ciria, A., y Sanguinetti, H., Ob. cit., 1983, pp. 56-58.

${ }^{622}$ Buchbinder, P., Ob. cit., 2008, p.128.

${ }^{623}$ Un texto clásico de esta postura fue publicado por Mella en 1925 bajo el título: “¿Puede ser un hecho la Reforma Universitaria?”, en Gabriel Del Mazo, La Reforma Universitaria, Lima, Universidad Nacional de San Marcos, 1968.

${ }_{624}$ “Qué es la Reforma Universitaria?”, en 1918-1998 La Reforma Universitaria, Bs. As., Editorial La Página, 1998, p. 12-13.
} 
referente institucional -la universidad-, pero borrosos límites ideológicos. Esta situación le permitió adquirir distintos significados, identificar adversarios, nombrar partidarios y aglutinar a diversas fuerzas en su interior a lo largo de la conflictiva historia universitaria $\operatorname{argentina}^{625}$.

\section{III - LA UNIVERSIDAD PERONISTA}

Los gobiernos de Perón inauguraron el segundo gran hito de la historia universitaria argentina del siglo XX. Como hay un antes y después de la Reforma, también existe un antes y después del peronismo. Sus principales políticas para la universidad están reglamentadas en un conjunto de legislaciones y programas, como los Planes Quinquenales, la Constitución de 1949 y la llamada Ley Guardo. Estas propuestas fueron configurando un discurso políticoacadémico que hizo hincapié en la dirección política de la enseñanza superior y en la democratización social de las casas de estudio. Detrás de esa ecuación, existía una redefinición de los lazos que ligaban al Estado, la universidad y la sociedad. No olvidemos que el peronismo se pensó a sí mismo como un movimiento nacional y su estructura universitaria siempre fue entendida como una matriz de producción de cultura, ciencia y profesionales al servicio de la comunidad, aunque en el diseño de la política académica promovió una organización jerárquica encabezada por un gobierno de profesores y mostró una actitud hostil a la militancia política estudiantil en el interior de las casas de estudio.

El Centro Universitario Argentino (CUA) fue creado en 1945, un poco antes de la elección de Perón como nuevo presidente constitucional con casi el 53 por ciento de los votos. Esta institución que nucleaba a distintos intelectuales que adhirieron al movimiento peronista sacó su segundo volumen de publicaciones tres años más tarde. La nueva edición contaba con un conjunto de intervenciones de personalidades vinculadas al debate político-cultural de ese entonces, como Ernesto Palacio, Homero Guglielmini, John William Cooke, Carlos Astrada, Arturo Jauretche y Guillermo Borda ${ }^{626}$. Estos escritos evidenciaban temáticas diversas, pero la centralidad estaba puesta en la educación superior. El mismo prólogo de la publicación contenía una versión taquigráfica de la conferencia que había pronunciado el director del

\footnotetext{
${ }^{625}$ Sigal, S., Intelectuales y poder en la década del sesenta, Bs. As., Puntosur, 1991. Un arco político amplio se identificó con las banderas de la Reforma en sus primeros años. Este inclúa a yrigoyenistas, grupos liberales próximos al alverismo, socialistas y anarquistas. Al ingresar a la década del treinta, hasta el propio Partido Comunista comenzaría a reivindicarlas con la fundación de la agrupación universitaria Insurrexit. Graciano O., Ob. cit, 2008, pp. 126-131; Buchbinder, P., Historia de las universidades argentinas, Bs. As., Sudamericana, 2010, p. 110; Kleiner, B., 20 años de movimiento estudiantil reformista. 1943-1963, Bs. As., Editorial Planeta, 1964, p. 19.

${ }^{626}$ Pronko, M., El peronismo en la universidad. Fragmentos de una memoria / documentos, Bs. As., Libros del Rojas, 2000, p. 13.
} 
CUA en 1947. Se trataba de la charla que dictó Ricardo Guardo para presentar en sociedad el primer proyecto de ley universitaria que impulsó el peronismo gobernante y él mismo había redactado en su carácter de diputado nacional ${ }^{627}$. En esa exposición, el antiguo graduado de honor de la UBA advertía sobre la necesidad de transformar todas las casas de estudio del país porque habían tergiversado el legado de la Reforma cuando comenzaron a reivindicar una independencia que ni la misma Ley Avellaneda reconocía y produjeron una camarilla de representantes estudiantiles que provenía de la elección de un pequeño círculo, ya que nunca llegó a implementarse la agremiación obligatoria de todo el alumnado ${ }^{628}$. Guardo resaltaba que la controversia de fondo estaba relacionada al interrogante sobre quién conducía la política universitaria, si una elite de académicos o la dirigencia política del Estado en representación de la sociedad. Para él no había dudas a esta altura y lo reflejaba haciendo suyo un mensaje de Perón que enfatizaba que una verdadera democracia en la universidad podía ser posible con rectores y consejeros designados por un poder ejecutivo libremente elegido por el voto popular. Y las casas de estudio tranquilamente podían gobernarse a sí mismas y no ser democráticas, ya que nada garantizaba que sigan el sentimiento mayoritario de la nación ${ }^{629}$.

El anteproyecto de Guardo llegó al congreso el 5 de marzo de 1947 con la firma de Perón y su ministro de Educación y Justicia, Belisario Gache Pirán, pero recién terminó de convertirse en ley el 26 de septiembre de ese mismo año. No fue un trámite fácil, estuvo marcado por intensos conflictos y discusiones sobre el camino a seguir en la universidad. El antiguo aliado de Perón en las jornadas del 17 de octubre y en las elecciones presidenciales formó parte de las voces más disgustadas con la propuesta. Cipriano Reyes era categórico: el proyecto oficialista no traía ninguna solución a los problemas existentes y sólo buscaba anular la autonomía de las universidades al transformarlas en simples reparticiones del poder ejecutivo $^{630}$. El discurso del diputado laborista cargaba las tintas sobre una de las dimensiones más importantes de la Ley 13.031. Ésta pretendía asegurar la dirección y la planificación estatal de la enseñanza superior modificando sus formas de gobierno. Aunque era la primera legislación que incorporaba un concepto de autonomía restringido a cuestiones técnicas, docentes, científicas y al ejercicio de la personería jurídica de la universidad, la normativa

\footnotetext{
${ }^{627}$ Guardo, R., "La Nueva Universidad Argentina”, en Pronko, M., Ob. cit., 2000, p. 24. Guardo se graduó de doctor en odontología por la UBA en 1929 y en medicina con diploma de honor en 1942. Fue Presidente del CUA desde 1945, Diputado por la Capital Federal durante el período 1946-1952, ejerciendo la presidencia de la Cámara hasta 1948.

${ }^{628}$ No está de más aclarar que el mismo Guardo consideraba como una verdadera revolución a la Reforma del '18. Para él, era la expresión de los descendientes de las masas inmigratorias y de la irrupción política del radicalismo.

${ }^{629}$ Guardo, R., Ob. cit., 2000, pp. 30-31.

${ }^{630}$ Pronko, M., Ob. cit., 2000, pp. 16-17.
} 
establecía una clara subordinación de las facultades al poder político. Los rectores eran designados por el ejecutivo y los consejos directivos que elegían los decanos estaban conformados por profesores que eran seleccionados por esa misma instancia. A su vez, introducía la idea de planificación a partir de la creación del Consejo Nacional Universitario, un organismo presidido por el ministro de Justicia e Instrucción Pública que estaba encargado de coordinar distintos aspectos de las universidades, como sus planes de estudio, las condiciones de ingresos, los sistemas de promoción y la expedición de títulos académicos ${ }^{631}$.

El peronismo no sólo tenía en cuenta una determinada concepción del vínculo entre Estado, universidad y sociedad a la hora de diseñar su proyecto académico. La ley 13.031 también evidenciaba el intento de bloquear políticamente al movimiento estudiantil. Guardo consideraba a la Reforma como una verdadera revolución, pero su esquema erradicó una de sus conquistas centrales. El ordenamiento legal que finalmente fue promulgado el 9 de octubre de 1947 prohibía la actividad política de los universitarios y reducía la representación estudiantil en los consejos directivos a un delegado sin poder de voto, quien debía ser elegido mediante un sorteo entre los diez alumnos del último año de mejores calificaciones ${ }^{632}$. Esta cuestión no era menor y había llevado al antiguo reformista y diputado Gabriel Del Mazo a señalar, en el mismo debate parlamentario que ratificó la normativa, que el gobierno terminó optando por una universidad autoritaria que sólo contemplaba la participación de uno de sus brazos y el pupilaje del poder ejecutivo ${ }^{633}$. A principios de los cincuenta, este panorama quedó mínimamente modificado con la aprobación de una nueva ley universitaria que seguía la reforma constitucional de 1949 y el segundo Plan Quinquenal. El justicialismo fue elevado a doctrina nacional y la normativa 14.297 implementó cursos de formación política obligatorios en las casas de estudio. Pero en el fondo, el nuevo ordenamiento legal de 1954 continuaba otorgando una escasa influencia política al estudiantado en los órganos de gobierno. Estos últimos podían contar con un representante que poseía capacidad de voto en cuestiones que afectaban los intereses del alumnado, pero necesitaba provenir de los últimos tres años de la carrera y formar parte de una entidad gremial reconocida por las instituciones oficiales.

La otra cuestión importante que traen a colación los dos primeros gobiernos peronistas fue el de los avances y las limitaciones de la democratización social de la

\footnotetext{
${ }^{631}$ Mignone, E., Ob. cit., 1998, pp. 26-29.

${ }^{632}$ Graciano, O., Ob. cit., 2008, p. 316.

${ }^{633}$ En el debate parlamentario también participaron otros referentes del movimiento reformista, como Luis Dellepiane y Emilio Ravigniani. Pronko, M., "La Universidad en el parlamento peronista", en Cucuzza, H. (dir.), Estudios de historia de la educación durante el primer peronismo 1943-1955, Bs. As., Editorial Libros del Riel, 1997, p. 246 y 249.
} 
enseñanza superior. En ese momento, el lema de "abrir las puertas de la universidad al pueblo" aludía a la necesidad de eliminar las trabas arancelarias y los exámenes de ingresos. Estos temas fueron discutidos por el reformismo en sus orígenes, pero nunca llegó a una militancia concreta y sistemática por la aplicación de esos principios. Durante los años del peronismo, la concreción de estas demandas no fue de un día para el otro. La Ley Guardo y la Constitución de 1949 garantizaban un sistema de becas, pero ninguna consagraba la gratuidad de los estudios superiores y el ingreso irrestricto ${ }^{634}$. La democratización social de las universidades mediante la supresión de aranceles recién se hizo efectiva mediante el decreto 4.493 que dictó el gobierno de Perón en 1952 y luego ratificó el poder legislativo en el artículo 71 de la ley universitaria 14.297, a lo que se sumó la eliminación del examen de ingreso en 1953. Este conjunto de políticas permitieron estimular un crecimiento exponencial de la matrícula universitaria y ampliar la base social del estudiantado con el ingreso de sectores populares que nunca habían ingresado a la educación superior, aunque un problema que nunca pudo superarse fueron las tasas extremadamente altas de deserción. Muchos ingresaban a las universidades y pocos alcanzaban la graduación. Una contrapartida para esta problemática fue la creación de la Universidad Obrera Nacional en 1948. Era uno de los aspectos más innovadores de la política peronista, pero recién pudo comenzar a funcionar regularmente cinco años más tarde. En el marco de las medidas industrialistas del gobierno, propuso la formación profesional de la clase trabajadora y una organización que permitía facilidades para quienes trabajaban. Sin embargo, fue sumamente cuestionada por muchos sectores políticos y académicos que la consideraban un sistema paralelo y discriminatorio ${ }^{635}$. Más allá de las controversias suscitadas, los diez años de gobierno peronista provocaron importantes cambios en la vida universitaria argentina. Muchas de sus realizaciones continúan rigiendo la enseñanza superior actual.

\footnotetext{
${ }^{634}$ Es más, la normativa 13.031 preveía la posibilidad de establecer el cobro de tarifas y exámenes de ingreso. Ibídem, p. 236.

${ }^{635}$ Buchbinder, P., Ob. cit., 2010, pp. 158-160.
} 


\section{REFERENCIAS BIBLIOGRÁFICAS}

- Acha, O., "Del rectorado al exilio (1970-1980)", en La nación futura: Rodolfo Puiggrós en las encrucijadas argentinas del siglo XX, Bs. As., Eudeba, 2006.

- Acha, O., "La autocrítica de la intelectualidad revolucionaria: Oscar Terán y la historia de las ideas argentinas", en Revista Herramienta, No 59, primavera 2016.

- Acha, O., La Nación Futura. Rodolfo Puiggrós en las encrucijadas argentina del siglo XX, Bs. As, Eudeba, 2006.

- $\quad$ Acha, O., Los muchachos peronistas. Orígenes olvidados de la Juventud Peronista (19451955), Bs. As., Planeta, 2011.

- Acha, O., Historia Crítica de la historiografía argentina. Vol. 1: las izquierdas en el siglo $X X$, Bs.As., Prometeo, 2009.

- $\quad$ Alcalde, R., Estrategia en la Universidad, Bs. As., Ediciones del MLN, 1964.

- Alonso, L., "El análisis sociológico de los discursos: una aproximación desde los usos concretos", en La mirada cualitativa en sociología, Madrid, Fundamentos, 1999.

- $\quad$ Altamirano, C., Bajo el signo de las masas, Bs. As., Emecé Editores, 2007.

- $\quad$ Altamirano, C., Peronismo y cultura de izquierda, Bs. As., Siglo XXI, 2011.

- $\quad$ Altamirano, C., y Sarlo, B., Literatura/Sociedad, Bs. As., Edicial, 1993.

- Amaral, S. y Plotkin, M. (comps.), Perón: del exilio al poder, Bs. As., EDUNTREF, 2004.

- Amato, F. y Boyanovsky, B., Setentistas. De La Plata a la Rosada, Bs. As., Sudamericana, 2009.

- Anguita, E, y Caparrós, M, La Voluntad. Una historia de la militancia revolucionaria en Argentina, 1966-1969, tomo 1, Bs. As., Booket, 2010a; 1969-1973, tomo 2, Bs. As., Booket, 2010b; 1973-1974, tomo 3, Bs. As., Booket, 2010c.

- Anzorena, O., Tiempo de violencia y utopía, Bs. As., Ediciones del Pensamiento Nacional, 1998.

- Aramburu, L. y Giorgi, G., "Recuperando trayectorias olvidadas: José Enrique Miguens, sociólogo", en Primer Congreso de Sociólogos de la Provincia de Buenos Aires, 2013.

- Argumedo, A, Los silencios y las voces en América Latina: notas sobre el pensamiento nacional y popular, Bs. As., Ediciones Colihue, 1993.

- Balvé, B., El 69: huelga política de masas. Rosariazo/ Cordobazo/ Rosariazo, Bs. As., Contrapunto, 1989.

- $\quad$ Barletta, A. M. y Lenci, M. L., "Politización las Ciencias Sociales en la Argentina. Incidencia de la revista Antropología 3er. Mundo 1968-1973”, en Cuadernos del CISH, N 8, FaHCE, UNLP, 
2001.

- Barletta, A. M., "Peronización de los universitarios (1966-1973). Elementos para rastrear la constitución de una política universitaria peronista", en Pensamiento Universitario, Nº 9, UNQUI, abril 2001.

- Barletta, A. M., "Una izquierda universitaria peronista. Entre la demanda académica y la demanda política (1968-1973)", en Prismas, Nº 6, UNQUI, 2002.

- Barletta, A. M., y Lenci, M. L., "Politización de las ciencias sociales en Argentina. El caso de la revista Antropología 3er. Mundo", en Sociohistórica, No 8, FaHCE, UNLP, 2001.

- Barletta, A. M., y Tortti, M. C., "Desperonización y peronización en la universidad en los comienzos de la partidización de la vida universitaria”, en Krotsch, P. (comp.), La universidad cautiva. Legados, marcas y horizontes, La Plata, Al Margen, 2002.

- Bartoletti, J. Montoneros: de la movilización a la organización. Un caso paradigmático de militarización, Tesis Doctoral, UNSAM, 2010.

- Baschetti, R. (comp.), Documentos 1970-1973: de la guerrilla peronista al gobierno popular, La Plata, De la Campana, 1995.

- Baschetti, R. (comp.), Documentos 1973-1976, Volumen I: De Cámpora a la ruptura, La Plata, De la Campana, 2004a.

- Baschetti, R. (comp.), Documentos 1973-1976, Volumen II: De la ruptura al golpe, La Plata, De la Campana, 2004b.

- $\quad$ Baschetti, R. (comp.), Documentos de la Resistencia Peronista 1955-1970, Bs. As., Puntosur, 1988.

- Baschetti, R., Peronistas que estudian. De los libros de lectura a la lectura de la realidad, Bs. As., Jironesdemivida, 2016.

- $\quad$ Bernetti, J., El peronismo de la victoria, Bs. As., Colihue, 2011.

- Besoky, J. L., La derecha peronista. Prácticas políticas y representaciones (1943-1976), Tesis Doctoral, FaHCE, UNLP, 2016.

- $\quad$ Bonasso, M., Diario de un clandestino. Bs. As., Planeta, 2000.

- Bonavena, P., "El peronismo estudiantil universitario 1966/1970", en XI Jornadas de Sociología de la UBA, 2015.

- Bonavena, P., "El rector que no fue. La lucha de los estudiantes de la UBA contra la designación del odontólogo Alberto Banfi en octubre de 1973”, en Bonavena, P., Califa, J. S., Millán, M., (comp.), El movimiento estudiantil argentino: historias con presente, Bs. As., Ed. Cooperativas, 2007.

- Bonavena, P., "Guerra contra el campo popular en los setenta. Juan Domingo Perón, la 
depuración ideológica y la ofensiva contra los gobernadores", en Izaguirre, I., Lucha de clases, guerra civil y genocidio en la Argentina 1973-1983, Bs. As., Eudeba, 2012.

- Bonavena, P., "Los estudiantes universitarios peronista. Del golpe de Onganía a los 'azos' del '69", en $V^{\circ}$ Jornadas de estudio y reflexión sobre el movimiento estudiantil argentino $y$ latinoamericano, 2014.

- Bozza, A., "El Peronismo Revolucionario. Itinerario y vertientes de la radicalización, 19591969”, en Sociohistórica-Cuadernos del CISH, N 10, Prometeo, UNLP, 2002.

- Bozza, A., "La resignificación revolucionaria del peronismo y sus protagonistas durante la etapa de proscripción", en Tortti, M. C. (dir.), La nueva izquierda argentina (1955-1976): socialismo, peronismo y revolución, Rosario, Prohistoria Ediciones, 2014.

- Buchbinder, P., ¿Revolución en los claustros? La Reforma Universitaria de 1918, Sudamericana, Bs. As., 2008.

- Buchbinder, P., "El movimiento reformista de 1918”, en Estudios Sociales, Santa Fe, N 19 , 2000 .

- Buchbinder, P., "La universidad y el tercer peronismo: notas sobre el debate parlamentario en torno a la Ley Taiana”, en Millán, M. (comp.), Universidad, politica y movimiento estudiantil en Argentina: entre la Revolución Libertadora y la democracia del '83, Bs. As., Final Abierto, 2014.

- Buchbinder, P., Historia de la Facultad de Filosofía y Letras, Bs. As., Eudeba, 2010.

- $\quad$ Buchbinder, P., Historia de las universidades argentinas, Bs. As., Sudamericana, 2010.

- $\quad$ Bufano, S. y Texidó, L., Perón y La Triple A. Las 20 advertencias a Montoneros, Bs. As., Sudamericana, 2015.

- $\quad$ Burgos, R., Los gramscianos argentinos, Bs. As., Siglo XXI, 2005.

- Caldelari, M., y Funes, P., Escenas reformistas. La Reforma Universitaria 1918-1930, Bs. As., Eudeba, 1998.

- Calderali, M., y Funes, P., "La Universidad de Buenos Aires 1955-1966: lecturas de un recuerdo", en Cultura y política en los años 60, UBA, Oficina de Publicaciones del CBC, 1997.

- Califa, J. S., “A la universidad con banderas reformistas. Los comunistas y la reconquistas de la Universidad de Buenos Aires 1968-1972”, en e-L@tina. Revista electrónica de estudios latinoamericanos, $\mathrm{N}^{0} 56,2016$.

- Califa, J. S., "El movimiento estudiantil en la UBA entre 1955 y 1976. Un estado de la cuestión y algunos elementos para su estudio”, en Bonavena, P., Califa, J. S., Millán, M., (comp.), El movimiento estudiantil argentino: historias con presente, Bs. As., Ed. Cooperativas, 2007.

- Califa, J. S., "El peronismo en la UBA durante la Rev. Argentina”, en VIII Jornadas Jóvenes Investigadores, Instituto Gino Germani, 2015. 
- Califa, J. S., Reforma y revolución. La radicalización política del movimiento estudiantil de la UBA 1943-1966, CABA, Eudeba, 2014.

- Camou, A., y Prati, M., "La planificación no es contraria a la democracia: donde hay desigualdad hay que planificar", en Cuestiones de Sociología, № 8, 2012.

- Cano, D., La educación superior en la Argentina, Bs. As., FLACSO/UNESCO, 1985.

- Carnagui, J.L., Nacionalistas, católicos y peronistas. Auge, afianzamiento y reconfiguración de la Concentración Nacional Univeristaria (CNU) La Plata, 1955-1974, Tesis Doctoral en Historia, FaHCE, UNLP, 2015.

- Carnovale, V., "Aportes y problemas de los testimonios en la reconstrucción del pasado reciente en la Argentina”, en Franco, M. y Levín, F. (comps.), Historia reciente. Perspectivas y desafios para un campo en construcción, Bs. As., Paidós, 2007.

- $\quad$ Carnovale, V., Los Combatientes. Historia del PRT-ERP, Bs. As., Siglo XXI, 2011.

- Castro, F. y Salas, E., Norberto Habegger. Cristiano, descamisado, montonero, Bs. As., Colihue, 2011.

- $\quad$ Cavarozzi, M., Autoritarismo y Democracia, Bs. As., CEAL, 1983.

- Ceballos, C. A., Los estudiantes universitarios y la política 1955-1970, Bs. As. CEAL, 1985.

- Celentano, A., "De la universidad necesaria a la universidad nueva: la recepción argentina de las tesis de Darcy Ribeiro entre 1967 y 1973”, en VII Jornadas de Sociología de la UNLP, La Plata, 2012.

- Celentano, A., "La actividad de las agrupaciones estudiantiles maoístas entre la lucha antidictatorial y el retorno del peronismo", en Revista em Pauta, Rio de Janeiro, $\mathrm{N}^{\mathrm{o}} 33,1^{\circ}$ semestre de 2014.

- Celentano, A., Revistas y libros de la nueva izquierda intelectual, Dossier $\mathrm{N}^{\circ}$ 84, Programa Interuniversitario de Historia Política, julio 2016.

- Celentano, A., y Tortti, M. C., "Estudiantes, izquierda y peronismo en la Argentina”, en Tortti, M. C. (dir.), La nueva izquierda argentina (1955-1976): socialismo, peronismo y revolución, Rosario, Prohistoria Ediciones, 2014.

- Celesia, F., y Waisberg, P., La Ley y las armas. Biografia de Rodolfo Ortega Peña, Bs. As., Aguilar, 2013.

- Cersósimo, F., Envar El Kadri. Historias del peronismo revolucionario, Bs. As., Colihue, 2008.

- Chama, M. y González Canosa, M., "Universidad, política y movimiento estudiantil: la Intervención de Kestelboim y el rol de la Juventud Universitaria Peronista en la Facultad de Derecho de la UBA”, en Conflicto Social, № 5, 2011. 
- Chama, M., "La expansión de los límites de lo posible. El itinerario de una experiencia innovadora en salud mental a fines de los '60”, en Pucciarelli, A. (ed.), La primacía de la política. Lanusse, Perón y la Nueva izquierda en tiempos del GAN, Bs. As., Eudeba, 1999.

- Chama, M., "Movilización y politización: abogados de Buenos Aires entre 1968 y 1973”, en Pérotin-Dumon, A. (dir.), Historizar el pasado vivo en América Latina., Universidad Alberto Hurtado, 2007.

- Chinchilla, J., "El Instituto del Tercer Mundo de la Universidad de Buenos Aires (19731974)", en Íconos, № 51, 2015.

- $\quad$ Ciria, A., y Sanguinetti, H., La Reforma Universitaria / 1, Bs. As., CEAL, 1983

- Combessie, J. C., El método en sociología, Córdoba, Ferreira Editor, 2005.

- Crespo, H., "En torno a Cuadernos de Pasado y Presente”, en Hilb, C. (comp.), El político y el cientifico, Bs. As., Siglo XXI, 2011.

- Cucchetti, H., Combatientes de Perón, herederos de Cristo, Bs. As., Prometeo, 2010.

- Daleo, G., Casareto, S., Cabrera, M., y Pico, A. (comps.), Filo (en) rompecabezas. Búsqueda colectiva de la memoria histórica institucional (1966-1983), Bs. As., Editorial de la FFyL, UBA, 2014.

- Dawyd, D., Sindicatos y política en la Argentina del Cordobazo. El peronismo entre la CGT de los Argentinos y la reorganización sindical (1968-1970), Pueblo Heredero, Bs. As., 2011.

- De Amézola, G., "El caso del realismo insuficiente. Lanusse, La Hora del Pueblo y el Gran Acuerdo Nacional”, en Pucciarelli (ed.), La primacía de la política. Lanusse, Perón y la Nueva Izquierda en tiempos del GAN, Bs. As., Eudeba, 1999.

- $\quad$ De Riz, L., La política en suspenso, 1966-1976, Bs. As., Paidós, 2000

- $\quad$ De Riz, L., Retorno y derrumbe. El último gobierno peronista, Bs. As., Hyspamérica, 1986.

- $\quad$ Del Mazo, G., Estudiantes y gobierno universitario, Bs. As., El Ateneo Editorial, 1955.

- Denaday, J. P., “Amelia Podetti: una trayectoria olvidada de las Cátedras Nacionales”, en Nuevo Mundo Mundos Nuevos, 2013.

- Deschner, K., La político de los Papas en el siglo XX, Zaragoza, Editorial Yalde, 2004.

- Devoto, F., y Pagano, N., Historia de la historiografía argentina, Bs. As., Sudamericana, 2010.

- Dip, N., "El peronismo universitario en un mundo de tensiones. Una aproximación al itinerario de las organizaciones de estudiantes y docentes peronistas de los años sesenta a través del estudio del proyecto de Universidad Nacional-Popular propuesto en la revista Envido", en Nuevo Mundo Mundos Nuevos, 2013.

- Dip, N., "En busca de un relato para la universidad. Reminiscencias reformistas y peronistas 
en Antropología 3er. Mundo", en E L@tina. Revista Electrónica de Estudios Latinoamericanos, 2016.

- Dip, N., "Peronismo y Universidad en los años sesenta. Una aproximación a las tramas discursivas y organizativas del proceso de peronización de los sectores estudiantiles y docentes de la Universidad de Buenos Aires (1966-1973)", en Cuestiones de Sociología. Revista de Estudios Sociales, № 8, UNLP, 2012.

- Donatello, L. M., "Religión y política: las redes sociales del catolicismo post-conciliar y los Montoneros, 1966-1973", en Estudios Sociales, N²4, Centro de Publicaciones de la Universidad Nacional del Litoral, Santa Fe, 2003.

- $\quad$ Donatello, L. M., Catolicismo y Montoneros, Bs. As., Manantial, 2010.

- Duzdevich, A., La lealtad: los montoneros que se quedaron con Perón, Bs. As., Sudamericana, 2015.

- Eggers Brass, T., "Conrado Eggers Lan, entre la filosofía antigua y el pensamiento nacional”, en Revista de Historia Bonaerense, № 39.

- $\quad$ Esquivada, G., Noticias de los Montoneros, Bs. As., Sudamericana, 2010.

- $\quad$ Finocchiaro, A., El mito reformista, Eudeba, Bs. As., 2014.

- Franco, M., Un enemigo para la nación. Orden interno, violencia y "subversión” 1973-1976, Bs. As., FCE, 2012.

- Friedemann, S., El marxismo peronista de Rodolfo Puiggrós. Una aproximación a la izquierda nacional, IIGG, UBA, Documento de jóvenes investigadores № 39, 2014.

- Friedemann, S., La Universidad Nacional y Popular de Buenos Aires (1973-1974). Una reforma universitaria inconclusa, FSOC, UBA, Tesis de Doctorado, 2015.

- Galasso, N., J.J. Hernández Arregui. Del peronismo al socialismo, Bs. As., Colihue, 2012.

- Gatto, E., "El poder y la plenitud”, en Cristianismo y Revolución: edición facsimilar, Bs. As., Biblioteca Nacional, 2015.

- Georgieff, G., Nación y revolución. Itinerarios de una controversia en Argentina (19601970), Bs. As., Prometeo, 2008.

- Ghilini, A. y Dip, N., "Experiencias de peronización en la Universidad de Buenos Aires entre la dictadura de Onganía y el gobierno de Cámpora", en Revista Izquierdas, N 25, octubre 2015.

- Gianella, C. (comp.), La vida es Perón. Historia del Encuadramiento de la Juventud Peronista, Bs. As., Biblos, 2012.

- Gil, G., “Cristianismo y Revolución. Una voz del jacobinismo de izquierda en los 60", Edición digital de Cristianismo y Revolución, Bs. As., CEDINCI, 2003.

- Gil, G., Universidad y utopía. Ciencias sociales y militancia en la Argentina de los 60 y 70, 
Mar del Plata, EUDEM, 2010.

- $\quad$ Gil, R., La izquierda peronista (1955-1974), Bs. As., CEAL, 1989.

- Gilbert, I., La Fede. Alistándose para la revolución. La Federación Juvenil Comunista 19212005, Bs. As., Sudamericana, 2009.

- Gillespie, R., Soldados de Perón: historia crítica sobre los Montoneros, Bs. As., Sudamericana, 2008.

- Gilman, C., "El intelectual como problema. La eclosión del antiintelectualismo latinoamericano de los sesenta y los setenta" en Prismas, No 3, UNQUI, 1999.

- $\quad$ Gilman, C., Entre la pluma y el fusil, Siglo XXI, Bs. As., 2012.

- González Canosa, M., "Las Organizaciones Armadas Peronistas (OAP): un análisis comparativo de los (re) posicionamientos de las FAR", en Tortti, M. C. (dir.), La nueva izquierda argentina (1955-1976): socialismo, peronismo y revolución, Rosario, Prohistoria Ediciones, 2014.

- González Canosa, M., Las Fuerzas Armadas Revolucionarias: Orígenes y desarrollo de una particular conjunción entre marxismo, peronismo y lucha armada, Tesis Doctoral, FaHCE, UNLP, 2012.

- González, H., Historia crítica de la Sociología argentina. Los raros, los clásicos, los cientificos, los discrepantes, Bs. As., Ediciones Colihue, 2000.

- Gordillo, M., "Protesta, rebelión, movilización: de la resistencia a la lucha armada, 19551973”, en James, D. (comp.), Violencia, proscripción y autoritarismo (1944-1976), Bs. As., Sudamericana, 2003.

- Graciano, O., Entre la torre de marfil y el compromiso político. Intelectuales de izquierda en la Argentina 1918-1955, Bernal, UNQUI, 2008.

- $\quad$ Grassi, R., El Descamisado. Periodismo sin aliento, Bs. As., Sudamericana, 2015.

- Halperín Donghi, T., Historia de la Universidad de Buenos Aires, Bs. As., Eudeba, 2002.

- Hernández Arregui, J. J., La formación de la conciencia nacional, Bs. As., Ediciones Continente, 2004.

- Hernández, J. P., Las JP: De Darwin Passaponti a Ramón Cesaris, Bs. As., Fabro, 2010.

- Hernández, J.P., Peronismo y pensamiento nacional. 1955-1973, Bs. As., Biblos, 1997.

- Hilb, C., El político y el científico, Bs. As., Siglo XXI, 2012.

- Hilb, C., y Lutzky, D., La nueva izquierda argentina: 1960-1980, Bs. As., CEAL, 1984.

- Izaguirre, I., “La Universidad y el Estado terrorista. La Misión Ivanissevich”, en Conflicto Social, $\mathrm{N}^{\mathrm{o}}$ 5, 2011.

- James, D., Resistencia e Integración. El peronismo y la clase trabajadora argentina 19461976, Bs. As., Sudamericana, 1999 
- Jauretche, A., El medio pelo en la sociedad Argentina, Bs. As., Corregidor, 2012.

- Javier Trímboli, La izquierda en la Argentina, Bs. As., Manantial, 1998.

- $\quad$ Kleiner, B., 20 años de Movimiento Estudiantil Reformista (1943-63), Bs. As., Platina, 1964.

- Krotsch, P., "Los universitarios como actores de reformas en América Latina ¿han muerto los movimientos estudiantiles", en Carli, S. (dir.), Universidad pública y experiencia estudiantil. Historia, política y vida cotidiana, Bs. As., Miño y Dávila, 2014.

- $\quad$ Lanusse, L., Montoneros. El mito de sus 12 fundadores, Bs. As., Vergara, 2007.

- Larraquy, M. y Caballero, R., Galimberti. De Perón a Susana de Montoneros a la CIA, Bs. As., Aguilar/Altea/ Taurus/Alfaguara, 2011.

- Lenci, L, “Cristianismo y Revolución (1966-1971): una primera mirada”, Edición digital de Cristianismo y Revolución, Bs. As., CEDINCI, 2003.

- Lenci, L., “Cámpora al Gobierno, Perón al Poder. La Tendencia revolucionaria del peronismo antes de las elecciones del 11 de marzo de 1973", en Pucciarelli, A. (ed.), La primacía de la política. Lanusse, Perón y la Nueva izquierda en tiempos del GAN, Bs. As., Eudeba, 1999.

- Lenci, L., "La radicalización de los católicos en Argentina. Peronismo, cristianismo y revolución (1966-1971)", en Sociohistórica, N 4, 1998.

- Longoni, A. y Mestman, M., Del Di Tella a “Tucumán Arde”. Vanguardia artística y política en el '68 argentino, Bs. As., El cielo por asalto, 2000.

- Mallimaci, F. y Giménez Beliveau, V., "Historia de vida y métodos biográficos", en Vasilachis de Gialdino, I., Estrategias cualitativas de investigación, Bs. As., Gedisa, 2007.

- Mariátegui, J.C., Siete ensayos de interpretación de la realidad peruana, Bs. As., Prometeo, 2010 [1928].

- $\quad$ Martin, A, y Spinelli, H., "Para que el hombre vuelva a cantar mientras trabaja. El Instituto de Medicina del Trabajo (IMT) y la salud de los trabajadores”, en Salud Colectiva, No 7, 2011.

- Martín, J. P., El Movimiento de Sacerdotes para el Tercer Mundo. Un debate argentino, Los polvorines, UNGS, 2010.

- Mayol, A., Habegger, N., y Armada, A., Los católicos posconciliares en la Argentina, Bs. As., Galerna, 1970.

- Micieli, C., Dar la vida / quitar la vida: el peronismo en los años 70 a través de las publicaciones El Descamisado y El Caudillo, Bs. As., La Parte Maldita, 2010.

- $\quad$ Mignone, E., Política y universidad. El Estado Legislador, Bs. As., Lugar Editorial, 1998.

- Millán, M., Entre la universidad y la política. Los movimientos estudiantiles de Corrientes y Resistencia, Rosario, Córdoba y Tucumán durante la Rev. Argentina (1966-1973), Tesis de Doctorado, FSOC., UBA, 2013. 
- Morello, G., Cristianismo y Revolución. Los orígenes intelectuales de la guerrilla argentina, Córdoba, Universidad Católica de Córdoba, 2003.

- $\quad$ Morero, S., La noche de los bastones largos 30 años después, Bs.As., Documentos Pagina 12, 1996.

- Moscona, G., Peronismo e intelectuales: la experiencia de las Cátedras Nacionales en la UBA en el período 1967-1974, Tesis de Maestría, FSOC, UBA, 2010.

- Muiño, O., La otra juventud. De la insignificancia al poder: protagonistas y relato de la Junta Coordinadora Nacional de la Juventud Radical (1968-1983), Bs. As., Corregidor, 2011a.

- Muiño, O., Los días de la Coordinadora: política, ideas, medios y sociedad (1968-1983), Bs. As., Corregidor, $2011 \mathrm{~b}$.

- Murmis, M., y Portantiero, J. C., Estudios sobre los orígenes del peronismo, Bs. As., Siglo XXI, 1972.

- Nadra, G. y Y., Montoneros: ideología y política en El Descamisado, Bs. As., Corregidor, 2011.

- Nahmías, G., "Roberto Carri: el pensamiento soslayado. Estudio preliminar", en Carri, R., Roberto Carri: obras completas, Bs. As., Biblioteca Nacional, 2015, Tomo I.

- Nassif, S. y Dawyd, D., "La revista Estudios Sindicales de Roberto Carri. Un documento para el estudio de la clase obrera de los sesenta”, en Corpus, № 2, 2014.

- $\quad$ Neiburg, F., Los intelectuales y la invención del peronismo. Bs. As., Alianza, 1998.

- Nievas, F., “Cámpora: primavera-otoño. Las tomas”, en Pucciarelli, A. (ed.), La primacía de la política. Lanusse, Perón y la Nueva izquierda en tiempos del GAN, Bs. As., Eudeba, 1999.

- Nievas, F., “Del Devotazo a Ezeiza. Guerra de posiciones en junio de 1973”, en Izaguirre, I. (coord.), Lucha de clases, guerra civil y genocidio en Argentina 1973-1983, Bs. As., Eudeba, 2009.

- Nievas, F., Las tomas durante el gobierno de Cámpora, Tesis de Maestría, FSOC, UBA, 1999.

- $\quad$ Noirel, G., Introducción a la sociohistoria, España, Siglo XXI, 2011.

- O’Donnell, G., El Estado Burocrático Autoritario, Bs. As., Ed. de Belgrano, 1982.

- Offerlé, M., Perímetros de lo político: contribuciones a una socio-historia de la política, Bs. As., Antropofagia, 2011.

- Ollier, M., El fenómeno insurreccional y la cultura política (1969-1973), CEAL, 1986.

- $\quad$ Ollier, M., Orden, política y violencia, CEAL, Bs. As., 1989.

- Ortiz, N., ¿Peronistas de Perón? Historia testimonial del encuadramiento de la Juventud Peronista, C.A.B.A., Biblioteca Nacional, 2015.

- $\quad$ Pacheco, J., Nacional y popular, Bs. As., Ediciones R y R, 2012. 
- Panella, C., “Actitud: un periódico nacionalista para los estudiantes universitarios peronistas”, en XIV Jornadas Interescuelas/Departamentos de Historia, FFyL, UNCUYO, 2013.

- $\quad$ Panella, C., "El regreso de una pesadilla: Perón y el tercer gobierno peronista en la visión del diario La Prensa", en Rein, R., y Panella, C. (comps.), El retorno de Perón y el peronismo en la visión de la prensa nacional y extranjera, La Plata, EDULP, 2009.

- Perdía, R., Montoneros. El peronismo combatiente en primera persona, Bs. As., Planeta, 2013.

- $\quad$ Perel, P., Raíces, E. y Perel, M., Universidad y dictadura. Derecho, entre la Liberación y el Orden, Bs. As., Ediciones del CCC, 2007.

- Pereyra, D., "Cincuenta años de la Carrera de Sociología de la UBA. Algunas notas contracelebratorias para repensar la historia de la Sociología en Argentina”, en Revista Argentina de Sociología, Vol. 9, Bs. As., 2007.

- Pereyra, D., "La Reforma universitaria en Argentina. Antecedentes, problemas y desafíos”, en Toribio D. (comp.), La universidad en la Argentina: miradas sobre su evolución y perspectivas, UNLA, 2010.

- Pereyra, D., "Sociologie als Beruf en Argentina", en IV Jornadas de Sociología de la Universidad de Buenos Aires, C.A.B.A., 2000.

- $\quad$ Pérez Lindo, A., Universidad, política y sociedad, Bs. As., Eudeba, 1985.

- Piovani, J. I., "La entrevista en profundidad", en: Marradi, A., Archenti, N. y J. I. Piovani (comps.), Metodología de las Ciencias Sociales, Bs. As., Emecé, 2007.

- Pollak, M. y Heinch, N., "El testimonio", en Pollak, M., Memoria, silencio y olvido, La Plata, Al Margen, 2006.

- Pollak, M., "Memoria e identidad social”, en Memoria, olvido, silencio, La Plata, Al margen, 2006.

- $\quad$ Pontoriero, G., Sacerdotes para el Tercer Mundo, Bs. As., CEAL, 1991.

- Portantiero J. C., Estudiantes y política en América Latina. El proceso de la Reforma Universitaria, Siglo XXI, México, 1987.

- Portantiero, J. C., "Economía y política en la crisis argentina", en Revista Mexicana de Sociología, No 12, México, 1977.

- Portantiero, J. C., "Studenti e populismo", en Studenti e rivoluzione nell' América Latina. Dalla Reforma Universitaria del 1918 a Fidel Castro, Milán, II Sagiatore, 1971.

- Portelli, A., "Lo que hace diferente a la historia oral", en Schwarzstein, D. (comp.), La historia oral, Bs. As., CEAL, 1991.

- Pozzoni, M., “'Leales’ y 'Traidores': la experiencia de disidencia de la Juventud Peronista 
Lealtad (1973-1974)”, en Nuevo Mundo Mundos Nuevos, junio 2013.

- Pozzoni, M., “'Una mirada sobre la militancia en los primeros años '70 a través de la revista Envido (1970- 1973)", en Nuevo Mundo Mundos Nuevos, enero 2012.

- Pozzoni, M., "La participación político-técnica de la izquierda peronista en el ministerio de educación bonaerense (1973-1974)”, en Estudios, Nº 8, julio-diciembre 2015.

- $\quad$ Pozzoni, M., Proyectos, ideas y prácticas políticas de las juventudes peronistas de izquierda en el contexto de la cultura política argentina. Provincia de Buenos Aires 1970-1976, Tesis de Doctorado, Universidad Nacional de Mar del Plata, Facultad de Humanidades, 2010.

- Pronko, M., "La Universidad en el parlamento peronista", en Cucuzza, H. (dir.), Estudios de la historia de la educación durante el primer peronismo 1943-1955, Editorial Libros del Riel, Bs. As., 1997.

- $\quad$ Pronko, M., El peronismo en la universidad. Fragmentos de una memoria / documentos, Bs. As., Libros del Rojas, 2000.

- Pucciarelli, A., "Dilemas irresueltos en la historia reciente de la sociedad argentina", Revista Taller, $\mathrm{N}^{\circ}$ 5, Bs. As. 1997.

- Raimundo, M., "En torno a los orígenes del peronismo revolucionario. El movimiento revolucionario peronista, en Taller. Revista de Sociedad, Cultura y Política, vol. V, N 12, Bs. As., 2000.

- Raimundo, M., "Izquierda peronista, clase obrera y violencia armada: una experiencia alternativa”, en Sociohistórica, № 15-16, 2004.

- Ramírez, A. J., "Radicalización y peronización de los estudiantes universitarios. El caso de la Universidad de La Plata", Cuadernos del CISH, N 5, 1999.

- Ramus, S., sueños sobrevivientes de una montonera a pesar de la ESMA, Bs. As. Colihue, 2000.

- Recalde, A., “La Universidad de Buenos Aires en la década de 1970: análisis del comunicado de prensa en solidaridad con Rodolfo Puiggrós”, en Salud Colectiva, № 3, 2012.

- $\quad$ Recalde, A., Intelectuales, peronismo y universidad, Bs. As., Punto de Encuentro, 2016.

- $\quad$ Recalde, A., Universidad y liberación Nacional, Bs. As., Nuevos Tiempos, 2007.

- Regali, E. A., Abelardo Ramos. La izquierda nacional y la nación latinoamericana, Córdoba, Ferreyra Editor/Ediciones del Corredor Austral/CICUSS, 2012.

- $\quad$ Reta, M. A., "El Frente Estudiantil Nacional (FEN): juventud y estudiantado en el proceso contestatario de los años sesenta en Argentina", en Antítesis, $\mathrm{N}^{\circ} 4$, Universidade Estadual de Londrina, Brasil, 2009.

- Reta, M. A., El proceso de peronización dentro del movimiento universitario en los años 
sesenta. El caso del FEN, Tesis de Maestría, FSOC, UBA, 2010.

- $\quad$ Rodríguez, L. G., Universidad, Peronismo y Dictadura 1973-1983, C.A.B.A, Prometeo, 2015.

- Rot, G. Los orígenes perdidos de la guerrilla en la Argentina: la historia de Jorge Ricardo Masetti y el EGP, Bs. As., Waldhuter, 2010.

- Rotunno, C. y Díaz Guijarro, E. (comps.), La construcción de lo posible. La Universidad de Buenos Aires de 1955 a 1966, Bs. As., Libros del Zorzal, 2003.

- Rubinich, L., "La modernización cultural y la irrupción de la sociología”, en James, D. (comp.), Violencia, proscripción y autoritarismo (1944-1976), Bs. As., Sudamericana, 2007.

- Ruiz Olabuénaga, J. I., Metodología de la investigación cualitativa, Universidad de Deusto, Bilbao, 1999.

- Salas, E., De resistencia y lucha armada, Ciudad Autónoma de Buenos Aires, Punto de Encuentro, 2014.

- Salas, E., La resistencia peronista: la toma del Frigorifico Lisandro de la Torre, Bs. As., CEAL, 1990.

- Sarlo, B., La batalla de las ideas, Bs. As., Ariel, 2000.

- Seia, G., "La lucha del movimiento estudiantil por el ingreso directo: una aproximación al caso de la UBA entre 1969 y 1973”, en Millán, M. (comp.), Universidad, política y el movimiento estudiantil en la Argentina, Bs. As., Final Abierto, 2014.

- Servetto, A. 73/76. El gobierno peronista contra las 'provincias montoneras', Bs. As., Siglo XXI, 2010.

- $\quad$ Sigal, S., Intelectuales y poder en la década del sesenta, Bs. As., Puntosur, 1991.

- Skocpol, T., "Estrategias recurrentes y nuevas agendas en sociología histórica", en Ansaldi, W. (comp.), Historia, Sociología, Sociología histórica, Bs. As., CEAL, 1994.

- Slipak, D., Las Revistas Montoneras. Cómo la organización construyó su identidad a través de sus publicaciones, Bs. As., Siglo XXI, 2015.

- Somoza, P., y Vinelli, E., "Para una historia de Los Libros", en Los Libros: edición facsimilar, Bs. As., Biblioteca Nacional, 2011.

- Sonderéguer, M. (comp.), Revista Crisis 1973-1976. Del intelectual comprometido al intelectual revolucionario, Bernal, UNQUI, 2011.

- Soprano, G., "De la pedagogía a la ciencia de la educación. A propósito de un estudio sobre intervenciones políticas y académicas de los pedagogos en el ámbito universitaria”, en Propuesta Educativa, $\mathrm{N}^{\circ} 28,2006$.

- Sotelo, L., "El mundo sindical entre la acción gremial y la acción política. Continuidades y rupturas de la CGT de los Argentinos respecto de las experiencias anteriores", en Tortti, M. C. 
(coord.), El lugar de la nueva izquierda en la historia reciente, PolHis - Boletín Bibliográfico Electrónico del Programa de Historia Política, No 10, segundo semestre de 2012.

- Suárez, F., “Algunas reflexiones sobre los procesos de institucionalización de la Sociología en la Argentina durante los últimos años”, en Revista Mexicana de Sociología, № 1, 1973.

- Suasnábar, C., Universidad e intelectuales. Educación y política en la Argentina (1955-1976), Bs. As., Manantial, 2004.

- Svampa, M., "El populismo imposible y sus actores, 1973-1976”, en James, D. (comp.), Violencia, proscripción y autoritarismo (1944-1976), Bs. As., Sudamericana, 2003.

- Tarcus, H., (dir.), Diccionario biográfico de la izquierda argentina, Bs. As., Emecé, 2007.

- Terán, O., "Ideas e intelectuales en la Argentina, 1880-1980", en Ideas en el siglo: intelectuales y cultura en el siglo XX latinoamericano, Bs. As., Siglo XXI, 2004.

- Terán, O., "Pensar el pasado", en Punto de Vista, No 58, agosto 1997.

- Terán, O., Nuestros años sesenta, Bs. As., Puntosur, 1991.

- $\quad$ Toer, M., El movimiento estudiantil de Perón a Alfonsín, Bs. As., CEAL, 1988.

- Toribio, D., "La expansión de la Educación Superior en contextos de crisis sociales y políticas", en La universidad en la Argentina: miradas sobre su evolución y perspectivas, UNLA, 2010.

- Torre, J. C., “A partir del Cordobazo”, en Ensayos sobre movimiento obrero y peronismo, Bs. As., Siglo XXI, 2012.

- Torre, J. C., “A propósito del Cordobazo”, Revista Estudio, № 4, Córdoba, 1994.

- Tortti, M. C., "Post Scriptum: la construcción de un campo temático" y "Protesta social y nueva izquierda en la Argentina del Gran Acuerdo Nacional” en Pucciarelli, A. (ed.), La primacía de la política. Lanusse, Perón y la Nueva izquierda en tiempos del GAN, Bs. As., Eudeba, 1999.

- $\quad$ Tortti, M. C., Che. Una revista de la nueva izquierda (1960-1961), Bs. As., CEDINCI, 2013.

- Tortti, M. C., El viejo partido socialista y los orígenes de la nueva izquierda, Bs. As., Prometeo, 2009.

- Tortti, M. C., y Chama, M., "Los nudos político-intelectuales de una trayectoria. Reportaje a J. C. Portantiero", en Cuestiones de Sociología, No 3, FaHCE, UNLP, 2005.

- $\quad$ Touraine, A., La sociedad post-industrial, Barcelona, Ariel, 1969.

- Touris, C., "Sociabilidad e identidad político-religiosa de los grupos católicos tercermundistas en la Argentina (1966-1976), en Mallo, S. y Moreyra, B. (comps.), Miradas sobre la historia social en la Argentina a comienzos del siglo XXI, Córdoba, Centro de Estudios Históricos, 2008.

- Valles, M., "La investigación documental: técnicas de lectura y documentación”, en Técnicas cualitativas de investigación social. Reflexión metodológica y práctica profesional, Madrid, 
Síntesis, 1997.

- Varsavsky, O., Ciencia, política y cientificismo, Bs. As., Capital Intelectual, 2010.

- Verbitsky, H., La violencia evangélica. De Lonardi al Cordobazo (1955-1969), Bs. As., Sudamericana, 2008.

- Verón, E., Imperialismo, lucha de clases y conocimiento. 25 años de la carrera de sociología en la Argentina, Bs. As., Tiempo Contemporáneo, 1974.

- Williams, R., Marxismo y literatura, Bs. As., Las Cuarenta, 2009.

- Zanca, J., Los intelectuales católicos y el fin de la cristiandad 1955-166, Bs. As., FCE, 2006. 


\section{FUENTES DOCUMENTALES}

\section{DIARIOS Y REVISTAS DE ALCANCE NACIONAL}

La Prensa, La Razón, La Opinión, La Nación, Clarín, Noticias, Panorama, Primera Plana.

\section{LA OPINIÓN}

- “Actúan como 'la Juventud del Delegado'. Realizarán un acto 'los demetrios', un esotérico grupo justicialista”, en La Opinión, 28 de noviembre 1971.

- "El reformismo marxista ganó los comicios en todos los centros de Buenos Aires", en La Opinión, 1 de noviembre 1972.

- "El triunfo del reformismo en los comicios de Filosofía. Duro revés para los insurreccionalistas", en La Opinión, 21 de noviembre 1972.

- "El reformismo marxista en mayoría en la FUBA", en La Opinión, 23 de noviembre 1972.

- "El voto en blanco en la izquierda antiparlamentaria", en La Opinión, 3 de marzo 1973.

- "Julio Cortázar llega a la Argentina convencido de que a pesar de las contradicciones, se consolida la vía al socialismo en América Latina”, en La Opinión, 11 de marzo 1973.

- "Rolando García propone crear un ministerio de Ciencia y Técnica”, en La Opinión, 24 de marzo 1973.

- "La universidad en el cambio revolucionario. Una investigación del antropólogo brasileño Darcy Ribeiro", en La Opinión, 25 de marzo 1973.

- “Mañana se anunciará la creación de la rama universitaria de la JP”, en La Opinión, 22 abril 1973.

- “Fenómenos nuevos obligan a reacomodar esquemas” en La Opinión, 22 de abril 1973.

- “Creará la juventud peronista su propio equipo técnico-político”, en La Opinión, 24 de abril 1973.

- "La composición de la JP determina sus propuestas radicalizadas", en La Opinión, 28 de abril 1973.

- "El Comando Tecnológico Peronista hizo conocer su propuesta sobre salud pública. Busca diferenciarse de las otras tendencias justicialistas”, en La Opinión, 28 de abril 1973.

- "Proyectos de los seis equipos técnicos-políticos”, en La Opinión, 28 de abril 1973.

- "Replanteó el ENA su actividad frente al nuevo gobierno", en La Opinión, 8 de mayo 1973;

“Censura comunista al llamado de Cámpora a la unidad nacional”, en La Opinión, 20 de mayo 
1973.

- "Se aclara el cuadro de oposiciones y alianzas del eminente gobierno", en La Opinión, 23 de mayo 1973.

- "Fueron ocupadas por peronistas todas las facultades de Buenos Aires y La Plata", en La Opinión, 29 de mayo 1973.

- "Cámpora decretó la intervención a las universidades nacionales", en La Opinión, 30 mayo 1973.

- "Nuevos decanos en siete facultades", en La Opinión, 31 de mayo 1973.

- "La reincorporación de los sancionados aumenta la base de apoyo de Puiggrós", en La Opinión, 12 de junio 1973.

- “Crean una comisión que redactará ley universitaria”, en La Opinión, 12 de junio 1973.

- "Primer intento opositor en la universidad local”, en La Opinión, 12 de junio 1973.

- "La gestión del rector Puiggrós suscita una ofensiva continuista", en La Opinión, 13 de junio 1973.

- "Apoyo de estudiantes y docentes jóvenes ratifica su línea de gobierno", en La Opinión, 13 de junio 1973

- "El decano de Derecho define pautas de su gestión. Kestelboim consultará a los claustros para modificar los planes de enseñanza", en La Opinión, 14 de junio 1973.

- "Hoy inicia sus tareas la comisión que redactará la futura ley universitaria, en La Opinión, 15 de junio 1973.

- "FUA-La Plata define los alcances de su apoyo a las autoridades universitarias, en La Opinión, 16 de junio 1973.

- “Disputas ideológicas en la Universidad”, en La Opinión, 19 de junio 1973.

- "Desfavorable reacción de estudiantes reformistas. Actúa la comisión redactora de una ley”, en La Opinión, 22 de junio 1973.

- “Jorge Taiana delimitó las atribuciones de los interventores de las casas de estudio", en $L a$ Opinión 26 de junio de 1973.

- “Puiggrós crea una nueva comisión”, en La Opinión, 27 de junio 1973.

- "Los estudiantes peronistas ocuparon ayer todas las facultades de la UBA", en La Opinión, 13 de julio 1973.

- “La elaboración de la nueva ley motiva polémicas en las casas de estudios”, en La Opinión, 2 de agosto 1973.

- "Drásticas instrucciones a los dirigentes del Movimiento para que excluyan todo atisbo de heterodoxia marxista”, en La Opinión, 2 de octubre 1973. 
- "A Puiggrós le fue exigida la renuncia y los delegados de facultades lo apoyan", en $L a$ Opinión, 2 de octubre 1973.

- “Ocuparon anoche el Rectorado de la Universidad”, en La Opinión, 3 de octubre 1973.

- “Perón no solicitó la renuncia de Puiggrós”, en La Opinión, 4 de octubre 1973.

- "Discute la JUP su apoyo a la gestión de Agoglia”, en La Opinión, 26 de octubre 1973.

- “La JUP rechaza a Agoglia como nuevo interventor”, en La Opinión, 27 de octubre 1973.

- “Ortega Peña anunció que no integrará el bloque de diputados del Frejuli”, en La Opinión, 14 de marzo 1974.

- "Surgió un nuevo sector en las huestes juveniles peronistas. La propuesta de la JP-Lealtad es afianzar la línea doctrinaria”, en La Opinión, 30 de abril 1974.

- “Lima abandonaría indeclinablemente la Universidad”, en La Opinión, 6 de julio 1974.

- $\quad$ "El doctor Lima deja hoy la Universidad de Buenos Aires, en La Opinión, 25 de julio 1974.

- "Laguzzi afirmó que no variará la política universitaria, en La Opinión, 26 de julio 1974.

- “Solidaridad con Puiggrós”, en La Opinión, 5 de septiembre 1974.

- El nucleamiento radical aspira a preservar la actividad académica", en La Opinión, 17 de septiembre 1974.

- “Talento y Ventura fueron alojados en Villa Devoto", en La Opinión, 23 de noviembre 1974.

- "Está contemplada la desaparición de los cuerpos de celadores en las Facultades", en $L a$ Opinión, 31 de diciembre de 1974.

\section{LA NACIÓN}

- “Libros político. Cuatro autores y una sola intención”, en La Nación, 7 de mayo 1973.

- “Mañana se anunciará la creación de la rama universitaria de la JP”, en La Opinión, 22 abril 1973.

- “Crea expectativa la movilización peronista”, en La Nación, 22 abril 1973.

- “Galimberti dijo cómo serán las milicias”, en La Nación, 23 abril 1973.

- “Bases de la JUP”, en La Nación, 24 abril 1973.

- “Concretó un proyecto la juventud peronista”, en La Nación, 25 de abril 1973.

- “Efectuará la FUBA un congreso de unidad”, en La Nación, 5 de mayo 1973.

- "El congreso de la FUBA. Concretaron la unidad fuerzas antagónicas", en La Nación, 8 de mayo 1973.

- “El activismo político en la universidad”, en La Nación, 12 de mayo 1973.

- “Ocuparon dependencias de la Universidad”, en La Nación, 29 de mayo 1973.

- “La intervención en la Universidad”, en La Nación, 31 de mayo 1973. 
- “La increíble situación universitaria”, en La Nación, 10 de junio 1973.

- “En Arquitectura y Medicina ganó la JUP”, en La Nación, 4 de diciembre 1973.

- El triunfo de la JUP y el futuro político", en La Nación, 6 de diciembre 1973.

- “Manifestación estudiantil en el Congreso", en La Nación, 21 de febrero 1974.

- “Posición de la JUP ante la ley universitaria”, en La Nación, 24 de febrero 1974.

- “Ocupaciones de facultades”, en La Nación, 19 de marzo 1974.

- "Normal actividad en el ámbito universitario", en La Nación, 20 de marzo 1974.

- "Fijaron su posición grupos estudiantiles", en La Nación, 29 de marzo 1974.

- "Expectativas ante la gestión que se inicia”, en La Nación, 30 de marzo 1974.

- “Ponen en funciones a los rectores", en La Nación, 30 de marzo 1974.

- "Fueron ocupadas las facultades anoche”, en La Nación, 14 de agosto 1974.

- “Montoneros pasó a la resistencia activa”, en La Nación, 7 de septiembre 1974.

- “Renunció el decano de Derecho”, en La Nación, 10 de septiembre 1974.

- "Habrá un plebiscito en la Universidad”, en La Nación, 14 de Septiembre 1974.

- "Prolongan en siete días el asueto universitario", en La Nación, 21 de septiembre 1974.

- "Promulgóse la ley antisubversiva”, en La Nación, 1 de Octubre 1974.

- “Señaló Ottalagano los objetivos de su gestión, en La Nación, 4 de Octubre 1974.

\section{NotiCIAS}

- “Compiten peronistas y marxistas”, en Noticias, 19 de noviembre 1973.

- “Bajo sueldos pero lo respaldan”, en Noticias, 21 de noviembre de 1973.

- "Habla el interventor en la universidad. Reportaje exclusivo a Ernesto Villanueva", en Noticias, 28 noviembre 1973.

- "Finalizan elecciones estudiantiles", en Noticias, 1 de diciembre 1973.

- “Terminó elección docente”, en Noticias, 2 de diciembre 1973.

- “Sufragaron 54 mil alumnos”, en Noticias, 5 de diciembre 1973.

- "Los estudiantes votaron con el país. Declaraciones exclusivas de Pablo Ventura, de la regional uno de la Juventud Universitaria Peronista", en Noticias, 5 de diciembre 1973.

- "JUP y Franja Morada cambian nombre a FUBA", en Noticias, 6 diciembre 1973.

- "Los radicales satisfechos. Reportaje a Enrique Arana, dirigente universitario de Franja Morada”, en Noticias, 6 de diciembre 1973.

- “Congreso de FUBA. Tratativas peronistas-radicales”, en Noticias, 7 de diciembre 1973.

- "Votaron 123 mil alumnos universitarios", en Noticias, 10 de diciembre 1973.

- “Storani presidiría FUA - Córdoba. Trascendió que su designación ya está acordada”, en 
Noticias, 14 de diciembre 1973.

- "El MOR no aspira a ser mayoría. Entrevista a Kreyness, presidente de FUA - La Plata", en Noticias, 14 de diciembre 1973.

- "A un paso de la unidad estudiantil. La JUP propuso integrar de inmediato una nueva central nacional”, en Noticias, 15 diciembre 1973.

- "FUBA. Mañana inicia su congreso. Acción mancomunada de peronistas y otros sectores", en Noticias, 21 diciembre 1973.

- "Se realiza hoy el congreso de la FUBA", en Noticias, 22 de diciembre 1973.

- "FULNBA: unidad estudiantil concretada", en Noticias, 24 de diciembre 1973.

- “Apoyo de la FULNBA a los interventores”, en Noticias, 26 de diciembre 1973.

- "La FULNBA no acepta que la ley sea sancionado durante el receso de verano y exige un debate previo", en Noticias, 29 de diciembre 1973.

- "La Ley Universitaria. Taiana respondió a las críticas del radicalismo", en Noticias, 19 de febrero 1974.

- "Ley universitaria: piden postergarla”, en Noticias, 21 de febrero 1974.

- “La Universidad. La JUP apoya la ley”, en Noticias, 24 de febrero 1974.

- "Hoy entran los ocho diputados. Reemplazarán a los que renunciaron por aponerse a la ley represiva", en Noticias, 13 de marzo 1974.

- "La JUP convocó a la movilización. En un documento, llama a los estudiantes a sostener en sus a cargos a las actuales autoridades", en Noticias, 16 de marzo 1974.

- “Copan dos sedes universitarias", en Noticias, 19 de marzo 1974.

- "Por moción de Brito Lima diputados de la JP fuera del bloque", en Noticias, 21 de marzo 1974.

- “Universidad. Movilización en defensa de la actual política", en Noticias, 28 de marzo 1974.

- "Los estudiantes de varias universidades se movilizan en apoyo de actuales autoridades", en Noticias, 29 de marzo 1974.

- “La FULNBA habló con el nuevo rector”, en Noticias, 30 de marzo 1974.

- "Villanueva aceptó continuar en la Secretaría, en Noticias, 2 de abril 1974.

- "Solano Lima: revolución sin sangre. Asumió como rector de la universidad y pidió siembra de ideas", en Noticias, 3 de abril 1974.

- “ “Renunció Solano Lima?”, en Noticias, 2 de julio 1974.

- “Lima se va, nomás”, en Noticias, 25 de julio 1974.

- "Hay nuevo gabinete”, en Noticias, 15 de agosto 1974.

- "Despliegue policial para impedir el acto de la FULNBA", en Noticias, 15 de agosto 1974. 


\section{LA RAZóN}

- “Se acepta la renuncia de Puiggrós”, en La Razón, 2 de octubre 1973.

- "La Juventud Universitaria Peronista tomó el Rectorado y ocupó todas las Facultades", en $L a$ Razón, 3 de octubre de 1973.

- “El Problema Universitario”, en La Razón, 5 de octubre 1973.

- "Hay un compás de espera en el Problema Universitario”, en La Razón, 6 de octubre 1973.

- Agoglia, reemplazante de Puiggrós”, en La Razón, 25 de octubre 1973.

- “No reemplaza Agoglia a Puiggrós”, en La Razón, 27 de octubre 1973.

\section{LA PRENSA}

- “Los nuevos ministros”, en La Prensa 26 de mayo 1973.

- “Los no docentes ocuparon ayer la Universidad local”, en La Prensa, 29 mayo de 1973.

- "Fue puesto en funciones el nuevo interventor universitario", en La Prensa, 31 de mayo 1973.

- "Universidad intervenida y vilipendiada”, en La Prensa, 4 de junio 1973.

- "Marchas y contramarchas en la enseñanza superior", en La Prensa, 14 de junio 1973.

- “Designóse interventor universitario”, en La Prensa, 28 de noviembre 1973.

\section{Primera Plana}

- “Perón: tres horas con Primera Plana", en Primera Plana, Edición Especial, 30 de junio de 1966.

- “Declaraciones del Dr. Risieri Frondizi”, en Primera Plana, Nº 193, 6 de septiembre 1966.

- “Unión para la batalla”, en Primera Plana, № 482, 25 de abril 1972.

- “Herederos de la práctica popular”, en Primera Plana, º 488, 6 de junio 1972.

\section{OTRAS FUENTES PERIODÍSTICAS}

- "Prosigue el pleito en la Universidad Porteña", en Clarín, 30 de mayo 1973.

- “La conducción de Montoneros es Perón”, en Clarín, 14 de marzo 1974.

- “Actualidad de la Reforma Universitaria”, en Panorama, 14 de junio de 1973.

- "La CGT de los estudiantes", en Siete Días, julio 1968. Reproducido en http://www.magicasruinas.com.ar/revdesto069.htm.

- “Universitarios. La discordia, una vocación”, en Siete Días, 30 de junio 1969.

- "El respaldo del estudiantado", en Siete Días, 20 de julio 1973.

- "La cuestión de la autonomía es fundamental para la JRR”, El Cronista Comercial, 20 de 
febrero 1974.

- "El espíritu de Perón en las universidades argentinas", en Excelsior, México, 13 de febrero 1977.

- Bauer, Horacio W., "Un maestro de la militancia y la ciencia”, en Página 12, 14 de diciembre 2012 .

- Feinmann, J. P., “La historia con pasión”, en Página 12, 11 de marzo 2000.

\section{ReVistas POLÍTICO-INTELECTUALES Y UNIVERSITARIAS DEL PERONISMO}

Antropología 3er. Mundo, Envido, 4161

\section{ANTROPOLOGÍA 3ER. MUNDO}

- “Antropología, Antropologías”, en Antropología 3er. Mundo, No 1, noviembre de 1968.

- Podetti, A., "La antropología estructural de Lévi-Strauss y el Tercer Mundo", en Antropología 3er. Mundo, No 2, mayo de 1969.

- Carri, R., "El formalismo en las ciencias sociales (2da. Parte)", en Antropología 3er. Mundo, $\mathrm{N}^{\mathrm{o}} 2$, mayo de 1969.

- Eggers Lan, C., "Ideología, ciencia y estrategia”, en Antropología 3er. Mundo, No 2, mayo de 1969.

- Cárdenas, G., "El movimiento nacional y la universidad”, en Antropología 3er. Mundo, № 3 , noviembre de 1969.

- Gutiérrez, G., "Pensamiento nacional y política", en Antropología 3er. Mundo, N ${ }^{\circ}$, septiembre de 1970 .

- “FORJA y la Universidad”, en Antropología 3er. Mundo, № 4, septiembre de 1970.

- Wilner, N., "La tercera posición justicialista y el marxismo", en Antropología 3er. Mundo, No 4, septiembre de 1970.

- Guillán, J., "El movimiento nacional y el movimiento obrero" en Antropología 3er. Mundo, $N^{o} 4$, septiembre de 1970 .

- O’Farrell, J., "Pensamiento teórico y político", en Antropología 3er. Mundo, N 5, 1970. Olsson, G., "Notas sobre el pensamiento nacional”, en Antropología 3er. Mundo, № 5, 1970.

- Pecoraro, E., "La sociología nacional, las sociologías y la sociología”, en Antropología 3er. Mundo, $\mathrm{N}^{\mathrm{o}}$ 5, 1970.

- González, H., "Estrategia, Ideología, análisis institucional”, en Antropología 3er. Mundo, № 5 у 6, 1970. 
- Argumedo, A., "Notas sobre la polémica con el marxismo", en Antropología 3er. Mundo, $\mathrm{N}^{\mathrm{o}}$ 6, 1970.

- Carri, R., "Poder y dependencia", en Antropología 3er. Mundo, № 6, 1970.

- Licastro, J., "Negociación, conciliación y elección”, en Antropología 3er. Mundo, $\mathrm{N}^{\circ} 8$, septiembre-octubre de 1971.

- "El peronismo, desde la base”, en Antropología 3er. Mundo, № 8, septiembre-octubre de 1971.

- "CEP evalúa la experiencia del cuerpo de delegados de Filosofía y Letras", en Antropología 3er. Mundo, № 8, septiembre-octubre 1971.

- Getino, O., “62 modelo para desarmar”, en Antropología 3er. Mundo, No 8, septiembreoctubre de 1971.

- Habegger, N., "La Iglesia del Tercer Mundo", en Antropología 3er. Mundo, No 9, febreromarzo de 1972.

- "De base y con Perón. Un documento autocrítico de las ex - Cátedras Nacionales", en Antropología 3er. Mundo, $\mathrm{N}^{\mathrm{o}}$ 10, junio de 1972.

\section{ENVIDO}

- Consejo de Redacción, “La contradicción principal en la estructuración dependiente”, en Envido, $\mathrm{N}^{\circ} 1$, julio 1970.

- Ramírez, C., “Crónica política de enero a abril”, en Envido, № 1, julio 1970.

- Saravi, T., "Reportajes Biográficos: José María Rosa”, en Envido, № 2, noviembre 1970.

- $\quad$ Ramírez, C., "Salida política y conciliación nacional”, en Envido, № 2, noviembre 1970.

- Posadas, A., "Leopoldo Torre Nilson o la venganza de las vacas", en Envido, № 2, noviembre 1970.

- Villanueva, E., “La explotación de la sociología”, en Envido, Nº 2, noviembre 1970.

- Feinmann, J. P., "Felipe Varela y la lógica de los hechos”, en Envido, No 2, noviembre 1970.

- TUPAU, “Arquitectura y dependencia”, en Envido, № 2, noviembre 1970.

- Ramírez, C., "Cambio de fusibles en el gobierno”, en Envido, № 3, abril 1971.

- Feinmann, J. P., "Racionalidad e irracionalidad en Facundo", en Envido, No 3, abril 1971.

- Carri, R., "Imperialismo y coloniaje”, en Envido, No 3, abril 1971.

- Alcira, A., “Cátedras Nacionales: una experiencia peronista en la universidad”, en Envido, $\mathrm{N}^{\circ}$ 3, abril 1971.

- O’Farrell, J., “Mensaje a los compañeros”, en Envido, № 4, septiembre 1971.

- Saravi, T., "Reportaje a Rodolfo Puggrós”, en Envido, No 4, septiembre 1971. 
- González, S., "Manzi y Discepolín: el tango en la década infame”, en Envido, № 4, septiembre 1971.

- Ramírez, C., “Gobierno: el callejón del Gran Acuerdo”, en Envido, № 4, septiembre 1971.

- Dri, R., “Tercera Posición, marxismo y tercer mundo", en Envido, № 4, septiembre 1971.

- González, H., "Humanismo y Estrategia en Juan Perón”, en Envido, No 4, septiembre 1971.

- Varsavsky, O., "El ingeniero en la transición hacia el socialismo nacional", en Envido, № 5, marzo 1972.

- Ramírez, C., "El retroceso del régimen y el avance de Perón”, en Envido, № 5, marzo 1972.

- $\quad$ FORPE, “Sobre la guerra y el socialismo nacional”, en Envido, № 5, marzo de 1972.

- "Documento de agrupaciones universitarias peronistas. Primer Cabildo Abierto del Peronismo Universitario", en Envido, Nº 6, julio 1972.

- $\quad$ Feinmann, J. P., “El peronismo y sus intérpretes”, en Envido, № 6, julio 1972.

- Abrales, H., "La transferencia de tecnología, arma del imperialismo”, en Envido, № 6, julio 1972.

- $\quad$ Ramírez, C., "El Frente contra el GAN.”, en Envido, Nº 6, julio 1972.

- $\quad$ Feinmann, J. P., “Sobre el peronismo y sus intérpretes”, en Envido, No 6, julio 1972.

- Franco, J. P. y Álvarez, F., “Peronismo o desarrollismo”, en Envido, No 6, julio 1972.

- $\quad$ FEN-OUP, "Primer cabildo abierto del peronismo universitario, en Envido, № 6, julio 1972.

- CEP, “El frente de liberación nacional”, en Envido, № 6, julio 1972.

- Kesselman, H., "La penetración imperialista en el campo de la salud mental”, en Envido, No 7, octubre 1972.

- $\quad$ Ramírez, C., "Luche y vuelve”, en Envido, No 7, octubre 1972.

- "Declaración del Congreso Nacional de Estudiantes Peronistas", en Envido, № 7, octubre 1972.

- Sbarra Mitre, O., "Poder político popular y distribución del ingreso", en Envido, N 8, marzo 1973.

- $\quad$ ADUP, "Documento presentado por la Juventud Peronista al compañero Cámpora. Política universitaria", en Envido, № 8, marzo 1973.

- Ramírez, C., Santiago González continuó esta línea y escribió “Crónica del fracaso lanussista", en Envido, № 8, marzo 1973.

- Feinmann, J. P., “Cooke: peronismo e historia”, en Envido, № 8, marzo 1973.

- JUP, “Juventud Universitaria Peronista”, en Envido, № 9, mayo 1973.

- Ramírez, C., “Crónica del triunfo popular”, en Envido, № 9, mayo 1973.

- Fazio, H., "El gobierno popular y la construcción del socialismo nacional”, en Envido, $\mathrm{N}^{\circ}$ 9, 
mayo 1973.

- FURN, "La nueva universidad: resumen de pautas para su implementación”, en Envido, $\mathrm{N}^{\circ}$ 9, mayo 1973.

- "Esbozos críticos sobre algunas concepciones en el seno del peronismo", en Envido, $\mathrm{N}^{\circ}$ 10, noviembre 1973.

\section{1}

- “J.U.P. breve historia", en 4161, N 1, octubre 1963.

- "Desarrollismo, humanismo y reforma en el gobierno universitario", en 4161, $\mathrm{N}^{\circ} 2$, junio 1964.

- “Ocupación de las universidades por las Juventudes Universitarias Peronistas", en 4161, №2, junio 1964.

- “MNRT: violencia revolucionaria", en 4161, N², junio 1964.

\section{PublicaCiONES POLÍTICO-INTELECTUALES, POLÍTICO-PERIODÍSTICAS Y POLÍTICO- PROFESIONALES}

Semanario CGT, El Descamisado, Cristianismo y Revolución, Militancia Peronista para la Liberación, El Caudillo, Movimiento, Ciencia Nueva, Los Libros, Las Bases.

\section{Militancia Peronista}

- “La Prensa y La Nación frente a la Universidad”, en Militancia Peronista para la Liberación, $\mathrm{N}^{\mathrm{o}}$ 3, 27 de junio 1973.

- "Universidad. Fin de la dependencia", en Militancia Peronista para la Liberación, N 7, 26 de julio 1973.

- "Facultad de Derecho atacada por el gangsterismo", en Militancia Peronista para la Liberación, $\mathrm{N}^{\mathrm{o}}$ 21, 1 de noviembre 1973.

\section{LAS BASES}

- “Otro país, un país distinto y extraño", en Las Bases. Órgano oficial del Movimiento Nacional Justicialista, №63, 10 de octubre 1973.

- "La reforma: sus conquistas gremiales. Su instrumentación política”, en Las Bases. Órgano oficial del Movimiento Nacional Justicialista, № 65, 24 de octubre 1973.

- "El peronismo abre auténticamente las aulas al pueblo", en Las Bases. Órgano oficial del Movimiento Nacional Justicialista, № 67, 7 de noviembre 1973. 
- "Las leyes peronistas”, en Las Bases. Órgano oficial del Movimiento Nacional Justicialista, $\mathrm{N}^{\circ} 68,14$ de noviembre 1973.

- “La posición de FEN-OUP”, en Las Bases. Órgano oficial del Movimiento Nacional Justicialista, $\mathrm{N}^{\circ}$ 69, 21 de noviembre 1973.

- "VI congreso Nacional de la C.G:U.”, en Las Bases. Órgano oficial del Movimiento Nacional Justicialista, $\mathrm{N}^{\circ} 72,12$ de diciembre 1973.

- "Grave renuncia: atacan al gobierno del pueblo", en Las Bases. Órgano oficial del Movimiento Nacional Justicialista, № 73, 19 de diciembre 1973.

- "Universidad: el proyecto de la CNU” y "Universidad: la posición del Consejo Superior", en Las Bases. Órgano oficial del Movimiento Nacional Justicialista, № 78, 22 de enero 1974.

- "La hora del país real ha llegado", en Las Bases. Órgano oficial del Movimiento Nacional Justicialista, $\mathrm{N}^{\circ} 79,5$ de febrero 1974.

- “Hacia la universidad de los trabajadores. Los estudiantes ¡por la ley!”, en Las Bases. Órgano oficial del Movimiento Nacional Justicialista, № 85, 12 de marzo 1974.

\section{EL DESCAMISADO}

- “El país se pregunta: ¿Qué es la Juventud Peronista?”, en El Descamisado, Nº 8, 10 de julio 1973.

- "Primer Congreso Nacional de la Juventud Universitaria Peronista", en El Descamisado, No 17, 1 de septiembre 1973.

- "La consigna del imperialismo. Liquidar la Universidad antes del 12 de octubre", en El Descamisado, No 19, 26 de septiembre 1973.

- "La JUP denuncia una ofensiva reaccionaria que intenta frenar la Liberación Nacional”, en El Descamisado, № 20, 2 de octubre 1973.

- “Triunfó la Universidad Peronista”, en El Descamisado, № 21, 9 de octubre de 1973.

- “Triunfó la Universidad Peronista”, en El Descamisado, № 21, 9 de octubre 1973.

- "La universidad al borde de la opción: liberación o continuismo gorila”, El Descamisado, No 43, 12 marzo 1974.

\section{LOS LIBROS}

- "El movimiento estudiantil: de la Reforma al Cordobazo", en Los libros, № 21, agosto 1971.

- 'La agrupación docente '29 de Mayo' a los compañeros de Filosofía y Letras”, en Los libros, $\mathrm{N}^{\mathrm{o}} 23$, noviembre 1971

- “Universidad: cultura y dependencia”, en Los libros, N²3, noviembre 1971. 
- "Facultad de Arquitectura de Córdoba. La experiencia del Taller Total”, en Los libros, № 23, noviembre 1971.

- "Facultad de Arquitectura de Rosario. Balance de 6 meses de lucha", en Los libros, $\mathrm{N}^{\circ}$ 23, noviembre 1971.

\section{SEMANARIO CGT}

- “ $1{ }^{\circ}$ de mayo: mensaje a los trabajadores y al pueblo argentino”, en Semanario CGT, $\mathrm{N}^{\circ} 1,1$ de mayo 1968.

- “Azopardo medita, el pueblo lucha”, en Semanario CGT, № 10, 4 de julio 1968.

- “La semana estudiantil”, en Semanario CGT, № 17, 22 de agosto 1968.

- "Hablan los estudiantes”, Semanario CGT, N 33, 12 de diciembre 1968.

- “Sacerdotes del Pueblo”, en Semanario CGT, №33, 12 de diciembre 1968.

- "Los estudiantes son una columna de la liberación”, Semanario CGT, № 34, 19 de diciembre 1968.

\section{PASADO Y PRESENTE}

- Rozitchner, L, "Marxismo o cristianismo" en Pasado y Presente, No 2-3, Año 1, juliodiciembre 1963.

- Eggers Lan, C., “Acerca de 'marxismo o cristianismo'. Respuesta a la derecha marxista”, en Pasado y Presente, № 4, Año 1, enero-marzo 1964.

- "El único voto clasista es el voto al FREJULI", en Pasado y Presente, N ${ }^{\circ}$ 1(nueva serie), abril-junio 1973.

\section{CRISTIANISMO Y REVOLUCIÓN}

- “Habla Ongaro”, en Cristianismo y Revolución, № 13, primera quincena abril 1969.

- "Hacia el Congreso Nacional de Unidad. La crisis del movimiento estudiantil. Llamamiento de la FUA (Federación Universitaria Argentina)", en Cristianismo y Revolución, $\mathrm{N}^{\circ} 22$, enero de 1970.

- "Declaraciones del FEN (Frente Estudiantil Nacional)", en Cristianismo y Revolución, $\mathrm{N}^{\circ} 22$, enero de 1970.

- "Sociología: Instrumento de conocimiento y de lucha", diciembre 1969. Reproducido en Cristianismo y Revolución, № 22, enero de 1970.

- “Pasión y muerte de una institución”, en Cristianismo y Revolución, № 30, septiembre 1971. 


\section{CIENCIA NUEVA}

- “El decano de la inquisición”, en Ciencia Nueva, № 16, mayo de 1972.

- "El Consejo Tecnológico del Movimiento Nacional Justicialista", en Ciencia Nueva, $\mathrm{N}^{\circ} 18$, 18 de agosto 1972.

- “Mesa Redonda. La Universidad en América Latina”, en Ciencia Nueva, N 19, octubre de 1972.

- "No pone el hombro quien no quiere...", en Ciencia Nueva, № 27, octubre 1973.

- “U.B.A.”, en Ciencia Nueva, No 27, octubre 1973.

- Darcy, R., "Repensando la universidad", en La universidad nueva. Un proyecto, Bs. As., Ciencia Nueva, 1973.

\section{MOVIMIENTO}

- "Los hechos de la quincena", en Movimiento, No 0, segunda quincena abril 1974.

- "Ya hemos volteado 28 generales" en Movimiento, No 0, segunda quincena abril 1974.

- "Solano lima asperezas en la universidad", en Movimiento, $\mathrm{N}^{\circ}$ 0, segunda quincena abril 1974

- “Quincena 1. Los hechos”, en Movimiento, № 1, primera quincena mayo 1974.

- “Leales a Perón. Se reagrupan los jóvenes peronistas escindidos de la Tendencia”, en Movimiento, $\mathrm{N}^{\circ} 1$, primera quincena mayo 1974.

\section{LEYES, DECRETOS, DISCURSOS, RESOLUCIONES Y DOCUMENTOS DE LA UBA}

Resoluciones Consejo Superior, Decretos Nacionales, Programas de Estudio, Discursos y debates parlamentarios, Aportes para la Nueva Universidad y Boletín de la UNPBA

\section{DECRETOS NACIONALES}

- Decreto No 35, Bs. As., 29/05/1973, en Boletín Oficial de la República Argentina, № 22705, Año LXXXI, viernes 13 de julio 1973.

- Decreto No 37, Bs. As., 29/05/1973, en Boletín Oficial de la República Argentina, № 22.684, Año LXXXI, lunes 11 de junio 1973.

- Decreto No 949, Bs. As., 23/03/1974, en Boletín Oficial de la República Argentina, No 22885 , Año LXXXII, miércoles 3 de abril 1974.

- Decreto $\mathrm{N}^{\mathrm{o}} 1.574$, Bs. As., 02/10/1973, en Boletín Oficial de la República Argentina, $\mathrm{N}^{\mathrm{o}}$ 22.738, Año LXXXI, martes 6 de noviembre 1973.

- Decreto No 865, Bs.As., 17/09/1974, en Boletín Oficial de la República Argentina, N²2999, 
Año LXXXII, lunes 23 de septiembre 1974.

\section{DISCURSOS Y DEBATES PARLAMENTARIOS}

- Taiana, J., "Exposición de S.E. el señor Ministro de Cultura y Educación de la Nación, Dr. Jorge A. Taiana, ante el Honorable Congreso de La Nación presentando el Proyecto de Ley destinado a regir las Universidades Nacionales el 12 de febrero de 1974", en Espíritu y normas de aplicación de la Ley Universitaria, Ministerio de Cultura y Educación, Centro Nacional de Documentación e Información Educativa, Bs. As., 1974.

- Taiana, J., "La universidad no es una isla en el proceso nacional. Exposición del Señor Ministro de Cultura y Educación ante los Señores Interventores de las Universidades Nacionales en la reunión realizada el día 25 de junio”, Ministerio de Cultura y Educación, Centro Nacional de Documentación e Información Educativa, Bs. As., julio 1973.

- Ivanissevich, O., "Mensaje de su Excelencia el señor Ministro de Cultura y Educación doctor Oscar Ivanissevich. 10 de setiembre de 1974”, Ministerio de Cultura y Educación, Centro Nacional de Documentación e Información Educativa, Bs. As., 1974.

- Proyecto original y debate parlamentario de la Ley Taiana (20.654): diarios de sesiones de la Cámara de Senadores, $65^{\mathrm{a}}$ reunión, continuación de la $15^{\mathrm{a}}$ Sesión Extraordinaria, 4 y 5 de marzo 1974, pp. 3605-3632; 66ª reunión, $15^{\mathrm{a}}$ sesión extraordinaria, 7 y 8 de marzo 1974, pp. 3810-3825; $66^{\mathrm{a}}$ reunión, $16^{\mathrm{a}}$ sesión extraordinaria, 7 y 8 de marzo 1974, pp. 3675-3809; y de la Cámara de Diputados, 65ª Reunión, continuación de la $3^{\mathrm{a}}$ sesión extraordinaria, 13 y 14 de marzo 1974, pp. 6295-6369.

\section{RESOLUCIONES CONSEJO SUPERIOR DE LA UBA}

- $\quad$ Res. (C.S.) No 1, UBA, 31 de mayo 1973.

- $\quad$ Res. (C.S.) $\mathrm{N}^{\mathrm{o}} 2$ y No 3, UBA, 31 de mayo 1973.

- $\quad$ Res. (C.S.) No 4, UBA, 1 de junio 1973.

- $\quad$ Res. (C.S.) No 5 y No 7, UBA, 1de junio 1973.

- $\quad$ Res. (C.S.) No 8, UBA, 5 de junio 1973.

- $\quad$ Res. (C.S.) No 9, UBA, 5 de junio 1973.

- $\quad$ Res. (C.S.) No 10, UBA, 6 de junio 1973.

- $\quad$ Res. (C.S.) No 11, UBA, 7 de junio 1973.

- $\quad$ Res. (C.S.) No 12, UBA, 8 de junio 1973.

- $\quad$ Res. (C.S.) No 17, UBA, 14 de junio 1973.

- $\quad$ Res. (C.S.) No 18, UBA, 8 de junio 1973. 
- $\quad$ Res. (C.S.) No 29, UBA, 15 de junio 1973.

- $\quad$ Res. (C.S.) No 40 y No 41, UBA, 19 junio 1973.

- $\quad$ Res. (C.S.) No 47, UBA, 14 de enero 1974.

- $\quad$ Res. (C.S.) No 87, UBA, 18 de julio 1973.

- $\quad$ Res. (C.S.) No 89, UBA, 17 de julio 1973.

- $\quad$ Res. (C.S.) No 92, UBA, 17 de julio 1973.

- $\quad$ Res. (C.S.) No 132, UBA, 26 de julio 1973.

- $\quad$ Res. (C.S.) No 347, UBA, 30 de agosto 1973.

- $\quad$ Res. (C.S.) No 350, UBA, 30 de agosto 1973.

- $\quad$ Res. (C.S.) No 629, UBA, 9 de octubre 1973.

- $\quad$ Res. (C.S.) No 2 y 3, UBA, 4 de abril 1974.

- $\quad$ Res. (C.S.) No 10, 16 y 17, UBA, 8 de abril 1974.

- $\quad$ Res. (C.S.) No 470 a 477, UBA, 28 de marzo 1974.

- $\quad$ Res. (C.S.), UBA, No 704 y 705, 10 de septiembre 1974.

\section{APORTES PARA LA NUEVA UNIVERSIDAD Y BOLETÍN DE LA UNPBA}

- Aportes para la Nueva Universidad, Secretaría de Planeamiento, UNPBA, No 1, julio 1973; $\mathrm{N}^{\circ}$ 2, julio 1973; $\mathrm{N}^{\circ}$ 3, agosto 1973; $\mathrm{N}^{\circ}$ 4, septiembre 1973; $\mathrm{N}^{\circ}$ 5, enero 1974; $\mathrm{N}^{\circ}$ 6-7, mayo-junio 1974.

- "Lineamientos generales para la elaboración de la Ley Universitaria. Primer borrador. Esquema para discusión en las bases", en Aportes para la Nueva Universidad, Secretaría de Planeamiento, UNPBA, No 3, agosto 1973.

- JUP, "El peronismo en la universidad", abril 1973. Reproducido en Aportes para la nueva universidad, Secretaría de Planeamiento, UNPBA, No 1, julio de 1973.

- "Reportaje a los compañeros de ADUP", en Boletín de la Universidad Nacional y Popular de Buenos Aires, Dirección de Prensa y Difusión, 22 de noviembre 1973.

\section{PROGRAMAS}

- Programa $\mathrm{N}^{\mathrm{0}} 109$, Conflicto Social, UBA, Facultad de Filosofía y Letras, primer cuatrimestre1968.

- Programa $\mathrm{N}^{\mathrm{0}} 112$, Problemas socioeconómicos argentinos I, UBA, Facultad de Filosofía y Letras, primer cuatrimestre 1968.

- Programa $\mathrm{N}^{0} 113$, Problemas socioeconómicos de América Latina, UBA, Facultad de Filosofía y Letras, primer cuatrimestre1968. 
- Programa $\mathrm{N}^{\mathrm{0}} 115$, Sociología Sistemática, UBA, Facultad de Filosofía y Letras, primer cuatrimestre 1968.

- Programa $\mathrm{N}^{\mathrm{o}} 116$, Problemas socioeconómicos argentinos II, UBA, Facultad de Filosofía y Letras, segundo cuatrimestre 1968.

- Programa No 117, Sociología de América Latina, UBA, Facultad de Filosofía y Letras, segundo cuatrimestre 1968.

- $\quad$ Programa No 68, Problemas de Sistemática, UBA, Facultad de Filosofía y Letras, primer cuatrimestre 1969.

- $\quad$ Programa $N^{0} 153$, Nación y Estado, UBA, Facultad de Filosofía y Letras, primer cuatrimestre 1971.

\section{PUbLiCACIONES Y DOCUMENTOS DE DIVERSO ORDEN}

- "Declaración de la Universidad de Buenos Aires", 28 de junio de 1966, en: Baschetti, R., Peronistas que estudian. De los libros de lectura a la lectura de la realidad, Bs. As., Jironesdemivida, 2016.

- “Cristianismo y marxismo”, en Correo de CEFYL, № 2, Año 1, Octubre 1962.

- "Seis años de dictadura: por una solución democrática, popular y antiimperialista para la universidad y el país", en Apunte interno, Comisión Nacional Universitaria del Partido Comunista, 29 de julio de 1972.

- “Elecciones en Ingeniería”, en Bandera Roja, 10 de septiembre 1973.

- Kestelboim, M., “Una experiencia de militancia: la Asociación Gremial de Abogados”, en Peronismo y Socialismo, $\mathrm{N}^{\circ} 1,1973$.

- “Perón vive”, en Aluvión, № 1, Año 1, Julio 1974.

- “Cuentas claras y política espesa”, en El Caudillo, No 42, 6 de setiembre 1974.

- "Reportaje al compañero Juan Muciaccia (Secretario General de la J.P. de la R.A.)", en El Caudillo, No 5, 14 de diciembre 1973.

- "Facultad de Medicina: aquí también llegó el peronismo", en El Caudillo, № 48, 1 de noviembre 1974.

- "Preparan una nueva noche de los bastones largos", en La Causa Peronista, № 9, 3 de septiembre 1974.

- CNU, "LEY 13031 del 47”, agosto de 1972. Disponible en CPM. Archivo de la ex-DIPBA, Mesa A, Leg. N¹54, Foja 16.

- Comisión Nacional Universitaria del PC, "Seis años de dictadura: por una solución 
democrática, popular y antiimperialista para la universidad y el país”, 29 de julio 1972.

- JAEN, "El movimiento Nacional y la Iglesia", en Cuadernos del Movimiento Nacionalista Pampero, Bs.As., Sudestada, 1969.

- "La juventud universitaria de Córdoba a los hombres libres de Sudamérica: Manifiesto Liminar”, en 1918-1998 La Reforma Universitaria, Editorial La Página, Bs. As., 1998.

- "Discurso del Presidente de la Federación Universitaria Argentina", en Ciria, A., y Sanguinetti, H., La Reforma Universitaria / 1, CEAL, Bs. As., 1983.

- "Acta de fundación de la Unión Latinoamericana", en Ciria, A., y Sanguinetti, H., La Reforma Universitaria / 1, CEAL, Bs. As., 1983.

- "Proyecto de Ley Universitaria y bases estatutarias (1918)", en Ciria, A., y Sanguinetti, H., La Reforma Universitaria / 1, CEAL, Bs. As., 1983.

- Guardo, G., "La Nueva Universidad Argentina", en Pronko, M., El peronismo en la universidad. Fragmentos de una memoria / documentos, Bs. As., Libros del Rojas, 2000.

- Mella, J. A., “¿Puede ser un hecho la Reforma Universitaria?”, en Del Mazo, G., La Reforma Universitaria, Universidad Nacional de San Marcos, Lima, 1968.

- Bonavena, P., "Las luchas estudiantiles en la Argentina 1966/1976", Beca de perfeccionamiento de la Secretaría de Ciencia y Técnica de la UBA, IIGG, FSOC, 1992.

- FAU. Antología pedagógica. 4 años de producción político-pedagógica del peronismo en la Facultad de Arquitectura de Bs. As volcados en 15 meses de gobierno popular de la universidad., Bs. As., Departamento Pedagógico FAU, diciembre 1974.

- "Hay que defender la victoria", 22 de marzo 1973, en Cámpora, H., La revolución justicialista, Bs. As., Eudeba, 1973.

- “Mensaje ante la asamblea legislativa. 25 de mayo 1973”, en Cámpora, H., La revolución peronista, Bs. As., Eudeba, 1973.

- Lanusse, A., Mensaje reservado a los rectores interventores de las universidades nacionales, 5 de octubre de 1971.

- "Fondo Mario Testa" de la Universidad Nacional de Lanús: http://www.unla.edu.ar/index.php/fondo-mario-testa.

- Carta de Rodolfo Galimberti a Juan Domingo Perón, 15 de mayo 1972, en www.cedema.org/ver.php?id=227.

- Declaración de Docentes Peronistas, en Hernández Arregui, J. J., La formación de la conciencia nacional, Bs. As., Ed. Continente, 2004. 


\section{FUENTES TESTIMONIALES}

\section{ENTREVISTAS REALIZADAS}

- Entrevista a Alcira Argumedo, C.A.B.A., 01/11/2012.

- Entrevista a Enrique Pochat, Quilmes, 06/05/2013.

- Entrevista a Silvia Sigal, La Plata, 29/10/2013.

- Entrevista a Daniel Pautasso García, Quito, 10/01/2014.

- Entrevista a Ernesto Villanueva, Florencio Varela, 04/05/2014 y 17/09/2014.

- $\quad$ Entrevista a Roberto Corvaglia, C.A.B.A., 11/09/2015.

- $\quad$ Entrevista a Jorge Carpio, C.A.B.A., 20/11/2015 y 30/10/2015.

- Entrevista a Mario Kestelboim, C.A.B.A., 12/11/2015.

- $\quad$ Entrevista a Miguel Ponce, C.A.B.A., 20/11/2015 y 27/11/2015

- $\quad$ Entrevista a Oscar Balestieri, C.A.B.A., 02/12/2015.

- Entrevista a Horacio Fazio, C.A.B.A., 09/12/2015.

- $\quad$ Entrevista a Julieta Oddone, C.A.B.A., 16/12/2015.

- Entrevista a Rafael Pascual, C.A.B.A., 17/12/2015.

- Entrevista a Susana Checa, C.A.B.A., 22/12/2015.

- $\quad$ Entrevista a Luis Kon, C.A.B.A., 22/12/2015.

- Entrevista a Arturo Armada, C.A.B.A., 15/12/ 2015 y 29/12/2015.

- $\quad$ Entrevista a Enrique Martínez, C.A.B.A., 30/12/2015.

- Entrevista a Hugo Chumbita, C.A.B.A., 05/01/2016.

- $\quad$ Entrevista a Paulina Spinoso, C.A.B.A, 06/01/2016.

- $\quad$ Entrevista a Julio Testa, C.A.B.A., 11/01/2016.

- Entrevista a Héctor Poggiese, C.A.B.A., 12/01/2016.

- $\quad$ Entrevista a Pedro Galin, C.A.B.A., 12/01/2016.

- $\quad$ Entrevista a Ernesto Jauretche, La Plata, 15/01/2016.

- Entrevista a Roberto Marafioti, C.A.B.A., 06/01/2016 y 19/01/2016.

- Entrevista a Julio Bárbaro, C.A.B.A., 21/01/2016.

- Entrevista a Lorenzo Donohoe, C.A.B.A., 27/01/2016.

- Entrevista a Jorge Luis Bernetti, C.A.B.A, 06/02/2016.

- $\quad$ Entrevista a Adriana Puiggrós, C.A.B.A., 09/02/2016.

- Entrevista a Agusto Pérez, C.A.B.A., 02/05/2016.

- $\quad$ Entrevista a Miguel Talento, C.A.B.A., 11/01/2016 y 04/05/2016. 
- Entrevista a Iván Chambouleyron, C.A.B.A., 09/05/2016.

- $\quad$ Entrevista a Ernesto López, C.A.B.A., 18/05/2016.

- $\quad$ Entrevista a Juan Pablo Franco, C.A.B.A., 18/10/2016.

- Entrevista virtual a Guillermo Gutiérrez, 29/11/2016.

\section{ENTREVISTAS ÉDITAS}

- "Nos divertíamos como locos. Entrevista a Héctor Poggiese”, en Política, cultura y sociedad en los '70, $\mathrm{N}^{\circ}$ 2, Año 1, Julio 1997.

- "Nacional y popular" [Entrevista a Alcira Argumedo], en Política, cultura y sociedad en los '70, $\mathrm{N}^{\circ} 10,1998$.

- "Éramos como hojas en la tormenta" [Entrevista a Horacio González], en Política, cultura y sociedad en los '70, $\mathrm{N}^{\circ} 10,1998$.

- "La transición permanente" [Entrevista a Ernesto Villanueva], en Política, cultura y sociedad en $\operatorname{los}$ '70, $\mathrm{N}^{\circ} 10,1998$.

- Maderna, F., "Entrevista a Alcira Argumedo", en González, H. (comp.), Historia Crítica de la sociología argentina, Bs. As., Colihue, 2000.

- "Entrevista a Alcira Argumedo", en González, H., Historia crítica de la Sociología argentina. Los raros, los clásicos, los científicos, los discrepantes, Bs. As., Ediciones Colihue, 2000.

- Puiggrós, A., "La universidad del '73. Trascripción de una entrevista realizada a la Dra. Adriana Puiggrós”, Testimonios. A 25 años del golpe, CABA, FUBA/UBA/Página 12, 2000.

- Entrevista a Lelio Mármola realizada por Aritz Recalde, C.A.B.A., 23/06/2006.

- Entrevista a Arturo Armada 19/04/2008. Disponible en:

http://www.croquetadigital.com.ar/index.php?option=com_content\&task=view\&id=1768\&Itemid= $\underline{1}$

- Entrevista a Arturo Armada por Norberto Raffoul y Rodolfo Beltramini, 19/04/2008. En Envido. Revista de politica y ciencias sociales, edición facsimilar de la Editorial de la Facultad de Filosofía y Letras, UBA, 2010.

- Entrevista realizada a Jaime Sorín por Juan Molina y Vedia, C.A.B.A., 16/06/2015. Disponible en: http://archivosdarentrevistas.blogspot.com.ar.

- “Testimonio de Horacio Luis González”, en Archivo Testimonial de la Biblioteca Nacional Mariano Moreno, Bs. As., 2015. Disponible en:

http://trapalanda.bn.gov.ar/jspui/handle/123456789/15679 


\section{BIBLIOGRAFÍA Y AUTOBIOGRAFÍAS DE LOS PROTAGONISTAS DE LA ÉPOCA}

- Argumedo, A., "Roberto Carri”, en Carri, R, Roberto Carri: obras completas, Bs. As., Biblioteca Nacional, 2015, Tomo I.

- $\quad$ Armada, A., "Envido: por sus frutos los conoceréis", en El Ojo Mocho, № 16, verano 20012002.

- Bárbaro, J., Juicio a los 70, Bs. As., Sudamericana, 2009.

- Bernetti, J., "Righi: la recuperación democrática y el peronismo", en Controversia, $\mathrm{N}^{\circ} 1$, México, 1979.

- Cárdenas, G., Las luchas nacionales contra la dependencia, Bs. As., Galerna, 1969.

- Carri, R., Isidro Velázquez, Bs. As., Colihue, 2011.

- Carri, R., Poder imperialista y liberación nacional, Bs. As., Efece Ediciones, 1973

- Cereijido, M., La nuca de Houssay. La ciencia argentina entre Billiken y el exilio, México, FCE, 2000.

- $\quad$ Chambouleyron, I., La Lista, Bs. As., Liber Editores, 2014

- Corvaglia, R., "La militancia al servicio de la causa nacional y popular en los claustros universitarios", en Baschetti, R., Peronistas que estudian. De los libros de lectura a la lectura de la realidad, Bs. As., Jironesdemivida, 2016.

- Duhalde, E. L., “Apropósito de Carri y de su obra”, en Carri, R., Isidro Velázquez, Bs. As., Colihue, 2011

- Eggers Lan, C., Izquierda, peronismo y socialismo nacional, Bs. As., Ediciones Búsqueda, enero 1972.

- $\quad$ Eggers Lan, C., Peronismo y liberación nacional, Ediciones Búsqueda, febrero 1973.

- Feinmann, J. P., “La historia con pasión”, en Página 12, 11 de marzo de 2000. Disponible en: http://www.pagina12.com.ar/2000/00-03/00-03-11/contrata.htm

- $\quad$ Feinmann, J. P., El peronismo y la primacía de la política, Bs. As., Planeta, 2015.

- $\quad$ Feinmann, J. P., La sangre derramada, Bs. As., Booket, 1998.

- $\quad$ Feinmann, J. P., Peronismo. Filosofía política de una persistencia argentina, Bs. As., Planeta 2010, Tomo I.

- Feinmann, J. P., Peronismo. Filosofía política de una persistencia argentina, Bs. As., Planeta 2011, Tomo II.

- Feinmann, J. P., y González, H., Historia y pasión: la voluntad de pensarlo todo, Bs. As., Planeta, 2013.

- Frondizi, R., La universidad en un mundo de tensiones. Misión de las universidades en América Latina, Bs. As., Eudeba, 2005 [1971]. 
- González, H., "Envido, un frente intelectual en el lodo del lenguaje político", en Envido. Revista de política y ciencias sociales, Bs. As., edición facsimilar de la Biblioteca Nacional, 2011, Tomo I.

- Grabois, R., Memorias de Roberto Pajarito Grabois: de Alfredo Palacios a Juan Perón (1955-1974), C.A.B.A., Corregidor, 2014.

- Gutiérrez, G., “Antropología 3er Mundo. Cuatro década, algunas reflexiones sobre el contexto de origen”, en Antropología 3er. Mundo, Bs. As., edición facsimilar de la Editorial de la Facultad de Filosofía y Letras, 2009.

- Martínez, E., El proyecto universitario. Un aporte desde el peronismo, Bs. As., Ciencia Ediciones, 1975.

- Ottalagano, A., Soy fascista. ¿Y qué? Una vida al servicio de la patria, Bs. As, ROCA Producciones, 1983.

- Ponce, M., Testimonios. A 25 años del golpe, CABA, FUBA/UBA/Página 12, 2000.

- Puiggrós, A., "El '73”, en El lugar del saber. Conflictos y alternativas entre educación, conocimientos y política, Bs. As., Galerna, 2003

- Puiggrós, A., “La universidad argentina de 1973-1974”, en Controversia, No 1, octubre 1979 y “La universidad de 1973-1974”, en Puiggrós A., Controversia, № 2-3, diciembre 1979.

- Puiggrós, A., Rodolfo Puiggrós: retrato familiar de un intelectual militante, Bs. As., Taurus, 2010.

- Puiggrós, R., “Tesis sobre el Nacionalismo Popular Revolucionario”, en Las Izquierdas y el Problema Nacional, Bs. As., Ediciones Cepe, 1973.

- $\quad$ Puiggrós, R., La universidad del pueblo, Bs. As., Crisis, 1974.

- Ramus, S., Sueños sobrevivientes de una montonera a pesar de la ESMA, Bs. As. Colihue, 2000.

- $\quad$ Sadi, M., La resistencia después del final, Bs. As., Nuevos Tiempos, 2004.

- Taiana, J. A., Pueblo, educación y cultura, Bs. As., Ministerio de Cultura y Educación, 1973.

- $\quad$ Taiana, J., El último Perón. Testimonio de su médico y amigo, Bs. As., Planeta, 2000.

- Talento, M., "Sobre el '73: algunas reflexiones y recuerdos”, en Baschetti, R., Peronistas que estudian. De los libros de lectura a la lectura de la realidad, Bs. As., Jironesdemivida, 2016, pp. 209-211.

- Talento, M., "Sobre ilusiones, represión y memoria en el '73”, en Testimonios. A 25 años del golpe, C.A.B.A, FUBA/UBA/Página 12, 2000, pp. 68-79.

- Wilner, R., Ser Social y Tercer Mundo (Elementos para una lógica de lo nacional), Bs. As., Galerna, 1969. 